Supporting Information

\title{
Radical Ring-Closing/Ring-Opening Cascade Polymerization
}

Hanchu Huang, Wenqi Wang, Zefeng Zhou, Bohan Sun, Meirui An, Fredrik Haeffner, and Jia Niu*

Department of Chemistry, Boston College, Chestnut Hill, Massachusetts 02467, United States

*Correspondence to: jia.niu@bc.edu 


\section{Table of Contents}

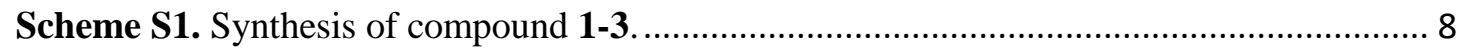

Scheme S2. Synthesis of model compound 4....................................................................... 10

Scheme S3. General procedure for synthesis of $\alpha$-methyl allylsulfone-containing macrocyclic monomers

Scheme S4. General procedure for synthesis of allylsulfone-containing macrocyclic monomers

Table S1. Crystal data and structure refinement for macrocyclic compound S13

Scheme S5. Ring-closing polymerization of monomer 3 . 20

Figure S1. MALDI-TOF analysis of polymer P-3 20

Figure S2. NMR spectral comparison of monomer $\mathbf{3}$ and polymer $\mathbf{P}-\mathbf{3}$.

Figure S3. Experimental validation that ring-closing polymerization does not initiate at the internal alkene.

Figure S4. Proposed mechanism for the ring-closing polymerization.

Figure S5. NMR determination of monomer conversion for the polymerization of monomer 3.

Table S2. Ring-closing polymerization of different monomers. .......................................... 25

Figure S6. SEC traces for ring-closing polymerization of different monomers..................... 25

Table S3. Effect of different CTAs on the polymerization of monomer 3 26

Figure S7. SEC traces for the effect of different CTAs on the polymerization of monomer 3.

Table S4. Solvent effect on the polymerization of monomer 3 .

Figure S8. SEC traces for the effect of different solvent on the polymerization of monomer 3 .

Table S5. Concentration effect on the polymerization of monomer 3. 28

Figure S9. SEC traces for the effect of different concentration on the polymerization. 28

Figure S10. Kinetic study on the polymerization of monomer 3 29

Scheme S6. Radical reaction of compound 4 30

Figure S11. ${ }^{1} \mathrm{H}$ NMR spectra of (A) 4, (B) crude NMR and (C) 5. 30

Figure S12. COSY spectra of product 5 . 31

Figure S13. HSQC spectra of product 5. 31 
Figure S14. Proposed mechanism for radical reaction of compound 4.

Figure S15. DFT calculation.

Scheme S7. Radical ring-closing/ring-opening cascade polymerization of macrocyclic monomer $\mathbf{1 0}$.

Figure S16. SEC traces of the polymerization of macrocyclic monomer $\mathbf{1 0 .}$

Scheme S8. Effect of CTA on the polymerization of macrocyclic monomer $\mathbf{1 0 .}$ 36

Figure S17. SEC traces of P-10 showed that adding CTA had little effect on the polymerization of $\mathbf{1 0}$.

Scheme S9. General procedure of radical ring-closing/ring-opening cascade polymerization in the presence of CTA

Figure S18. NMR determination of monomer conversion for the polymerization of monomer

11.

Table S6. Solvent effect on the polymerization of macrocyclic monomer $\mathbf{1 1 .}$

Figure S19. SEC traces of the polymerization of macrocyclic monomer $\mathbf{1 1}$ in different solvents

Table S7. Effect of different CTAs on the polymerization of macrocyclic monomer 11

Figure S20. SEC traces of the polymerization of macrocyclic monomer 11 in the presence of different CTAs.

Table S8. Effect of different CTA/AIBN ratio on the polymerization of macrocyclic monomer.

Figure S21. SEC traces of the polymerization of macrocyclic monomer 11 at different monomer/CTA ratios and different solvents.

Table S9. Different monomer/CTA ratio on the polymerization of macrocyclic monomer 11.

Figure S22. SEC traces of the polymerization of macrocyclic monomer $\mathbf{1 1}$ at different monomer/CTA ratios.

Table S10. Different monomer/CTA ratio on the polymerization of macrocyclic monomer 12.

Figure S23. SEC traces of the polymerization of macrocyclic monomer $\mathbf{1 2}$ at different monomer/CTA ratios.

Table S11. Different monomer/CTA ratio on the polymerization of macrocyclic monomer 13. 
Figure S24. SEC traces of the polymerization of macrocyclic monomer $\mathbf{1 3}$ at different monomer/CTA ratios.

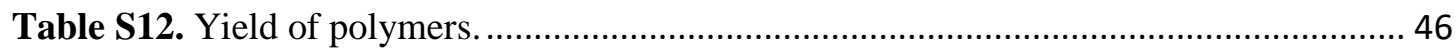

Figure S25. Compare $M_{\mathrm{n}(\mathrm{SEC})}, M_{\mathrm{n}(\mathrm{NMR})}$ and $M_{\mathrm{n}(\mathrm{LS})}$ of polymer P-11 ................................. 47

Figure S26. Kinetic study on the polymerization of macrocyclic monomer 11.................... 48

Figure S27. NMR determination of side reaction for the polymerization of 11.................... 50

Figure S28. NMR determination of side reaction for the polymerization of $13 \ldots \ldots \ldots \ldots \ldots \ldots . . . . . . .50$

Figure S29. Proposed mechanism for the ring-closing/ring-opening polymerization............ 51

Figure S30. TGA thermograms of different polymers recorded under argon at a heating rate of $10^{\circ} \mathrm{C} / \mathrm{min}$

Figure S31. DSC thermograms of different polymers recorded under argon during the second

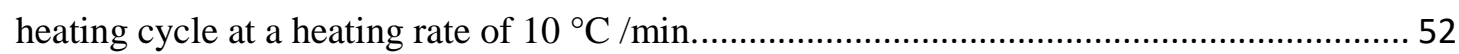

Figure S32. ${ }^{1} \mathrm{H}$ NMR analysis of model product 5 and polymers P-11 - P-13.................... 53

Figure S33. ${ }^{13} \mathrm{C}$ NMR analysis of the model product 5 and polymers P-11 - P-13 .............. 54

Figure S34. NMR analysis of polymer P-10 and its comparison with the spectra of P-11... 55

Figure S35. MALDI-TOF analysis of polymer P-11. .................................................... 55

Scheme S10. Post-modification of P-12 by metathesis. ……............................................... 56

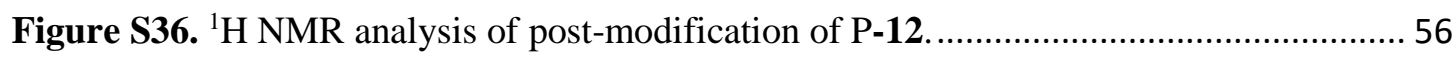

Figure S37. SEC trace of post-modification of P-12 .................................................... 57

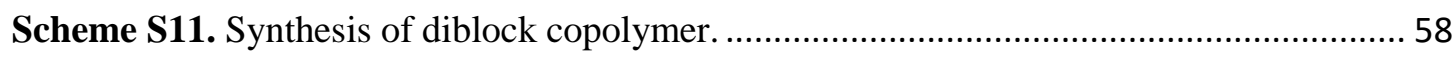

Figure S38. SEC traces of the block copolymerization..................................................... 58

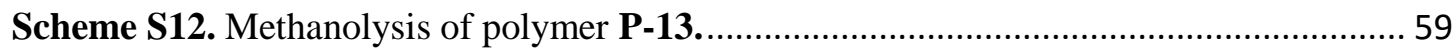

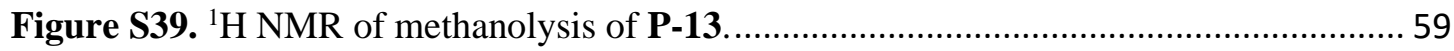

Figure S40. Mass spectrometry analysis of the methanolysis of P-13 .................................6 60

Scheme S13. Derivatization and isolation of degradation product.........................................6 61

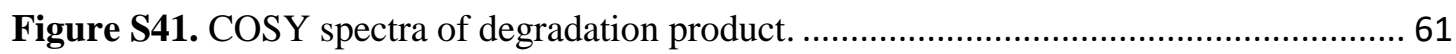

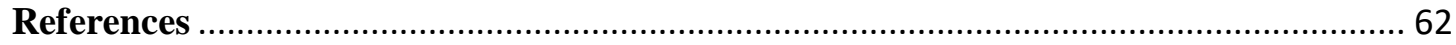

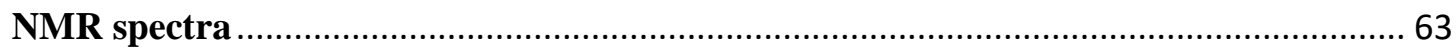

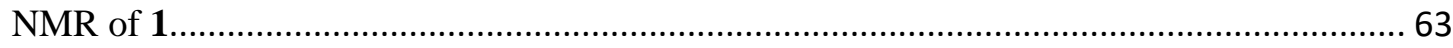

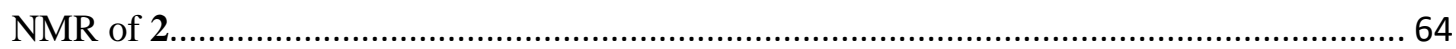

NMR of 3 


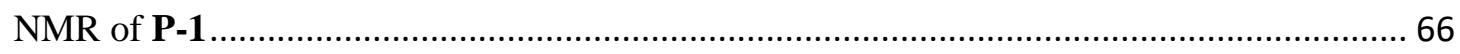

NMR of P-2

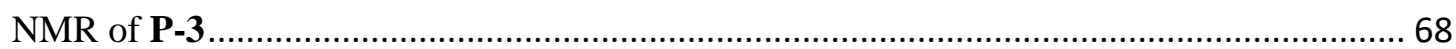

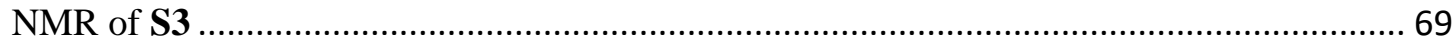

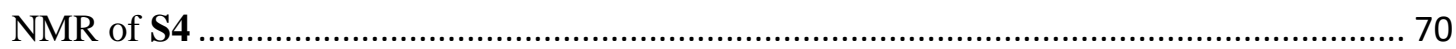

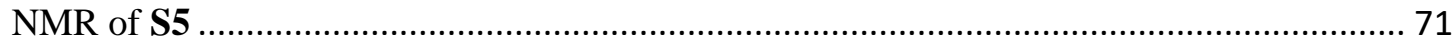

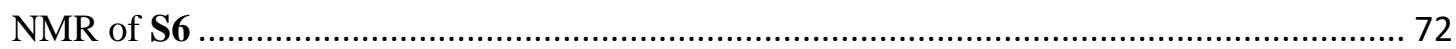

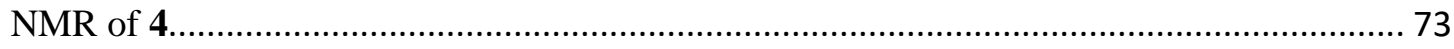

NMR of 5

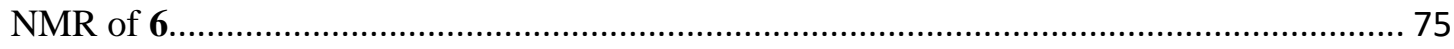

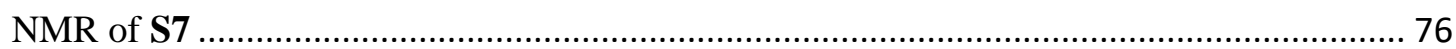

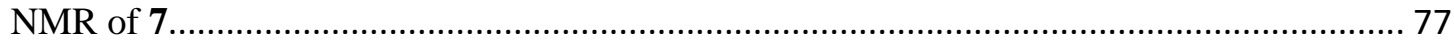

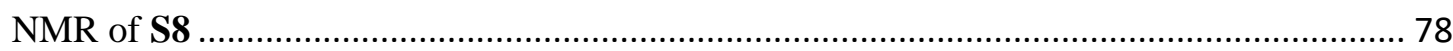

NMR of 8

NMR of 9

NMR of 10

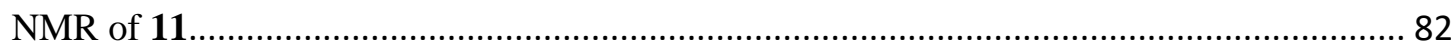

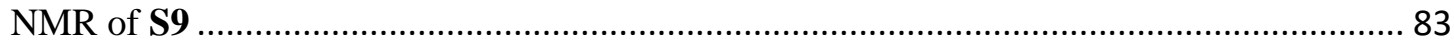

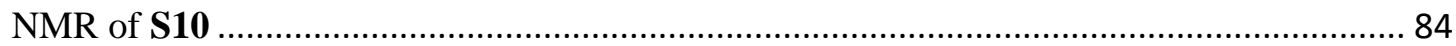

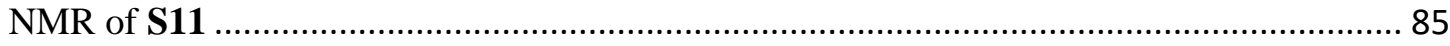

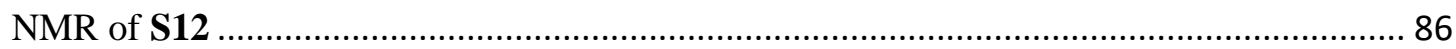

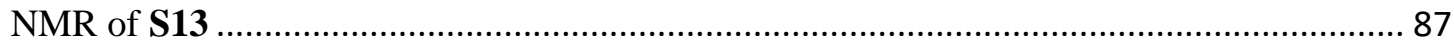

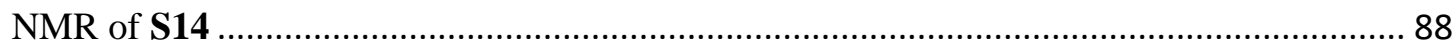

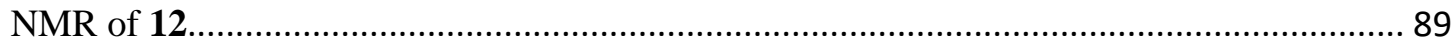

NMR of 13

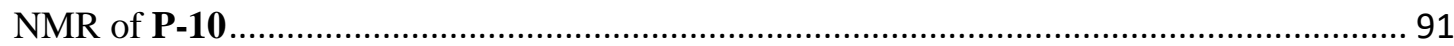

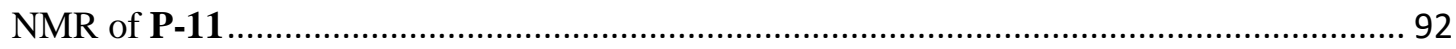

NMR of P-12

NMR of P-13

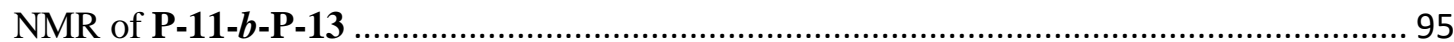


NMR of S15 .

96

Cartesian coordinates from DFT calculation. 97 


\section{Experimental Section}

Materials. The organic solvents such as toluene, chlorobenzene 1,4-dioxane, dimethyl sulfoxide (DMSO) and dimethyformamide (DMF) were purchased from Sigma-Aldrich and used as received. Chain transfer regents were prepared according to the reported procedures. ${ }^{1}$ Azobis(isobutyronitrile) (AIBN) was purchased from Sigma-Aldrich and was recrystallized from methanol before use. All other reagents were purchased from either Aldrich, Alfa Aesar or Acros and used without further purification. Thin layer chromatography was performed on Merck TLC plates (silica gel 60 F254). Silica gel chromatography was carried out using an automated flash chromatography (Biotage).

Characterization. ${ }^{1} \mathrm{H}$ and ${ }^{13} \mathrm{C}$ NMR spectra were recorded in $\mathrm{CDCl}_{3}$, unless otherwise noted, on either a Varian Gemini-600 (600 MHz) or Varian Inova-500 (500 MHz) spectrometer using residual chloroform ( $\delta=7.26$ for ${ }^{1} \mathrm{H}$ and $\delta=77.16$ for ${ }^{13} \mathrm{C}$ ) as internal standard. High-resolution mass spectrometry was performed on a JEOL AccuTOF DART Micromass LCT ESI-MS and an Agilent 6220 Time-of-Flight LC/MS instruments. Matrix-assisted laser desorption/ionization time-of-flight (MALDI-TOF) mass spectrometry was performed on an Applied Biosystem Voyager DE instrument (positive mode). Size-exclusion chromatography (SEC) measurements were performed on a Tosoh's high performance SEC system HLC-8320GPC with TSKgel Alpha-M columns at $50{ }^{\circ} \mathrm{C}$ and a flow rate of $0.6 \mathrm{~mL} / \mathrm{min}$. HPLC grade dimethylformamide (DMF) with $0.01 \mathrm{M} \mathrm{LiBr}$ (anhydrous, purchased from Sigma-Aldrich) was used as the eluent. Polystyrene standards (ReadyCal Kit, Sigma-Aldrich\#81434) were used to determine the molecular weight and molecular weight distribution of polymers. The polymers were dissolved in the above DMF solution and filtered through a $0.20 \mu \mathrm{m}$ PTFE filter before being injected into the SEC system. Gel permeation chromatography (light scattering detector) was performed on an Agilent GPC220 in THF at $40{ }^{\circ} \mathrm{C}$ with three PL gel columns $(10 \mu \mathrm{m})$ in series.

DFT Calculations: All geometry optimizations and frequency calculations were carried out employing the B3LYP/6-31G* method. All computed frequencies are real except the transition state structures, which have one imaginary frequency. Single-point energies were calculated using the B3LYP/6-311++G**//6-31G* method in conjunction with the PCM dielectric continuum model simulating the effect from the $N, N$-dimethylformamide solvent. Gibbs free energies $(298.15 \mathrm{~K}$ and $1.0 \mathrm{~atm})$ were computed as the sum of the single-point energies and the Gibbs free energy corrections using unscaled normal mode frequencies. All quantum chemical calculations were carried out with the Gaussian 09 computer program. ${ }^{2}$ 


\section{Experimental Procedures}

Scheme S1. Synthesis of compound 1-3.
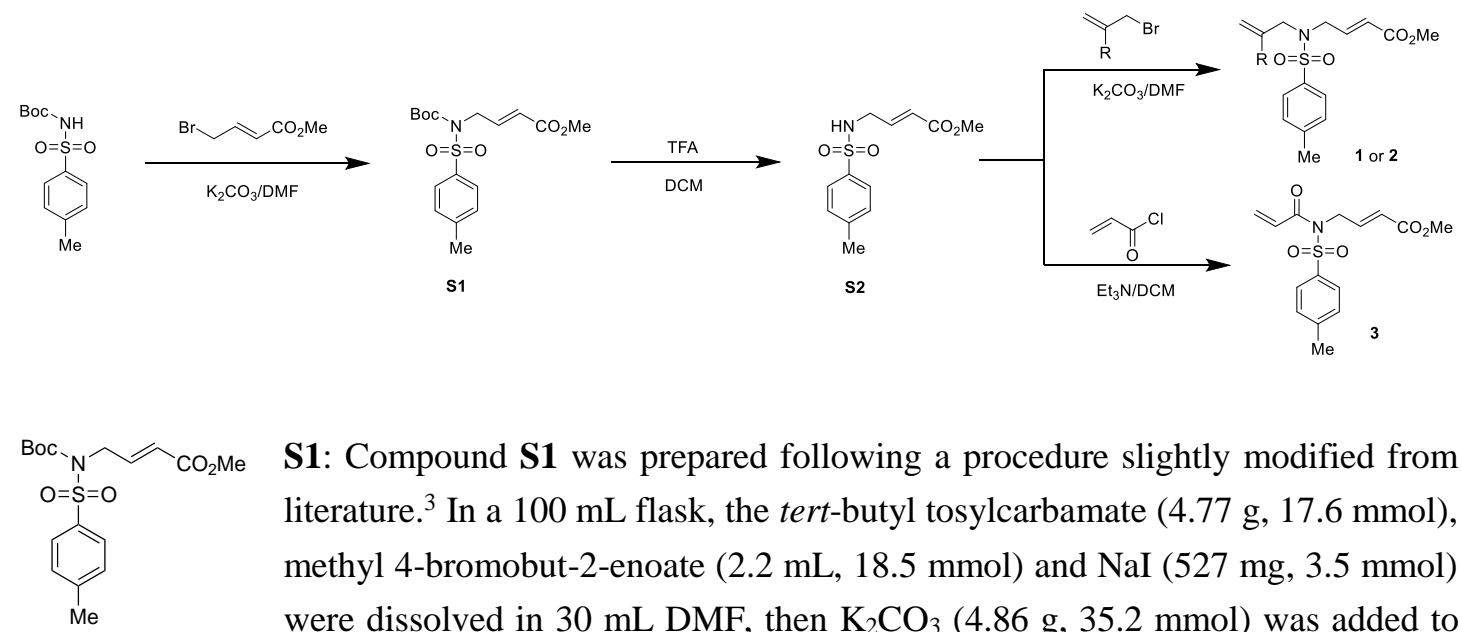

S1: Compound S1 was prepared following a procedure slightly modified from literature. ${ }^{3}$ In a $100 \mathrm{~mL}$ flask, the tert-butyl tosylcarbamate $(4.77 \mathrm{~g}, 17.6 \mathrm{mmol})$, methyl 4-bromobut-2-enoate (2.2 mL, $18.5 \mathrm{mmol})$ and $\mathrm{NaI}(527 \mathrm{mg}, 3.5 \mathrm{mmol})$ were dissolved in $30 \mathrm{~mL} \mathrm{DMF}$, then $\mathrm{K}_{2} \mathrm{CO}_{3}(4.86 \mathrm{~g}, 35.2 \mathrm{mmol})$ was added to the mixture, which was heated at $60{ }^{\circ} \mathrm{C}$ for 3 hours. The reaction was quenched with water and extracted with ethyl acetate (EtOAc) $(3 \times 30 \mathrm{~mL})$. The organic phase was washed three times with brine, dried over $\mathrm{Na}_{2} \mathrm{SO}_{4}$, filtered and concentrated under vacuum. The crude was purified by recrystallization (hexane/ DCM) to afford the product as an orange solid $(5.41 \mathrm{~g}, 83 \%) .{ }^{1} \mathrm{H}$ NMR $\left(500 \mathrm{MHz}, \mathrm{CDCl}_{3}\right): \delta 7.78(\mathrm{~d}, J=8.4 \mathrm{~Hz}, 2 \mathrm{H}), 7.31(\mathrm{~d}, J=8.0 \mathrm{~Hz}, 2 \mathrm{H}), 6.95(\mathrm{dt}, J=15.7,5.3 \mathrm{~Hz}$, 1H), $6.01(\mathrm{dt}, J=15.7,1.6 \mathrm{~Hz}, 1 \mathrm{H}), 4.58(\mathrm{dd}, J=5.4,1.7 \mathrm{~Hz}, 2 \mathrm{H}), 3.75$ (s, 3H), 2.44 (s, 3H), 1.35 (s, 9H).

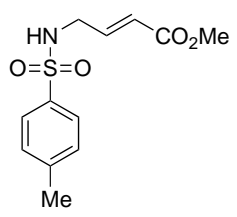

S2: Compound $\mathbf{S 2}$ was prepared following a procedure slightly modified from literature. ${ }^{3}$ In a $100 \mathrm{~mL}$ flask, S1 (2.44 g, $\left.6.6 \mathrm{mmol}\right)$ was dissolved in $20 \mathrm{~mL} \mathrm{DCM}$, the mixture was cooled at $0{ }^{\circ} \mathrm{C}$, then TFA $(3.1 \mathrm{~mL}, 39.6 \mathrm{mmol})$ was slowly added and the reaction was stirred for 16 hours at room temperature. The reaction was quenched with saturate sodium bicarbonate solution and extracted with DCM $(3 \times 30 \mathrm{~mL})$. The organic phase was washed with brine, dried over $\mathrm{Na}_{2} \mathrm{SO}_{4}$, filtered and concentrated under vacuum. The residue was purified by recrystallization (hexane/DCM) to afford the product as a white solid $(1.59 \mathrm{~g}, 89 \%) .{ }^{1} \mathrm{H}$ NMR $\left(500 \mathrm{MHz}, \mathrm{CDCl}_{3}\right): \delta 7.75(\mathrm{~d}, J=8.3 \mathrm{~Hz}, 2 \mathrm{H}), 7.32(\mathrm{~d}, J=8.4 \mathrm{~Hz}, 2 \mathrm{H})$, 6.77 (dt, $J=15.7,5.3 \mathrm{~Hz}, 1 \mathrm{H}), 5.94$ (dt, $J=15.7,1.8 \mathrm{~Hz}, 1 \mathrm{H}$ ), 4.56 (br, 1H), 3.76 (ddd, $J=6.6,5.4$, $1.8 \mathrm{~Hz}, 2 \mathrm{H}), 3.72(\mathrm{~s}, 3 \mathrm{H}), 2.43(\mathrm{~s}, 3 \mathrm{H})$.

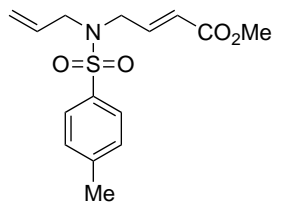

1: The reaction mixture of $(E)-4-((4-m e t h y l p h e n y l) s u l f o n a m i d o) b u t-2-e n o a t e$ S2 (360 mg, $1.34 \mathrm{mmol})$, allyl bromide (194 mg, $1.60 \mathrm{mmol})$ and $\mathrm{K}_{2} \mathrm{CO}_{3}(369$ $\mathrm{mg}, 2.67 \mathrm{mmol}$ ) in $10 \mathrm{~mL}$ DMF was stirred at room temperature for $15 \mathrm{~h}$. The reaction was quenched with $50 \mathrm{~mL}$ water and extracted with EtOAc $(3 \times 30$ $\mathrm{mL})$. The combined organic layers were washed with brine $(30 \mathrm{~mL})$, dried over $\mathrm{Na}_{2} \mathrm{SO}_{4}$ and concentrated in vacuo. The crude material was purified by flash column chromatography to give a white solid (293 mg, 71\% yield). ${ }^{1} \mathrm{H}$ NMR (600 MHz, $\left.\mathrm{CDCl}_{3}\right): \delta 7.69(\mathrm{~d}, J=8.3 \mathrm{~Hz}, 2 \mathrm{H}), 7.31$ (d, $J=7.9 \mathrm{~Hz}, 2 \mathrm{H}), 6.72(\mathrm{dt}, J=15.7,5.8 \mathrm{~Hz}, 1 \mathrm{H}), 5.91(\mathrm{dt}, J=15.7,1.6 \mathrm{~Hz}, 1 \mathrm{H}), 5.59$ (ddt, $J=16.7$, $10.2,6.5 \mathrm{~Hz}, 1 \mathrm{H}), 5.20-5.10(\mathrm{~m}, 2 \mathrm{H}), 3.91(\mathrm{dd}, J=5.8,1.6 \mathrm{~Hz}, 2 \mathrm{H}), 3.79(\mathrm{~d}, J=6.5 \mathrm{~Hz}, 2 \mathrm{H}), 3.72$ (s, 3H), 2.43 (s, 3H); ${ }^{13} \mathrm{C}$ NMR (150 MHz, $\left.\mathrm{CDCl}_{3}\right): \delta 166.2,143.8,142.8,136.9,132.3,130.0,127.3$, 
123.6, 119.9, 51.8, 50.6, 47.4, 21.7; HRMS (m/z) $[\mathrm{M}+\mathrm{H}]^{+}$calc'd for $\mathrm{C}_{15} \mathrm{H}_{20} \mathrm{NO}_{4} \mathrm{~S}, 310.1108$, found 310.1089 .

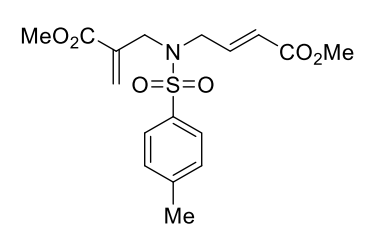

2: The reaction mixture of (E)-4-((4-methylphenyl)sulfonamido)but- 2enoate $\mathbf{S 2}$ (539 mg, $2.0 \mathrm{mmol}$ ), methyl 2-(bromomethyl)acrylate (430 mg, $2.4 \mathrm{mmol}$ ) and $\mathrm{K}_{2} \mathrm{CO}_{3}(553 \mathrm{mg}, 4.0 \mathrm{mmol})$ in $15 \mathrm{~mL}$ DMF was stirred at room temperature for $15 \mathrm{~h}$. The reaction was quenched with $50 \mathrm{~mL}$ water and extracted with EtOAc $(3 \times 30 \mathrm{~mL})$. The combined organic layers were washed with brine $(30 \mathrm{~mL})$, dried over $\mathrm{Na}_{2} \mathrm{SO}_{4}$ and concentrated in vacuo. The crude material was purified by flash column chromatography to give a white solid (526 mg, 72\% yield). ${ }^{1} \mathrm{H}$ NMR (600 $\left.\mathrm{MHz}, \mathrm{CDCl}_{3}\right): \delta 7.69(\mathrm{~d}, J=8.3 \mathrm{~Hz}, 2 \mathrm{H}), 7.31(\mathrm{~d}, J=8.0 \mathrm{~Hz}, 2 \mathrm{H}), 6.66(\mathrm{dt}, J=15.7,6.0 \mathrm{~Hz}, 1 \mathrm{H})$, 6.37-6.32 (m, 1H), 5.90-5.80 (m, 2H), $4.02(\mathrm{~s}, 2 \mathrm{H}), 3.96(\mathrm{dd}, J=6.0,1.4 \mathrm{~Hz}, 2 \mathrm{H}), 3.71(\mathrm{~s}, 3 \mathrm{H})$, $3.70(\mathrm{~s}, 3 \mathrm{H}), 2.43$ (s, 3H); ${ }^{13} \mathrm{C}$ NMR $\left(150 \mathrm{MHz}, \mathrm{CDCl}_{3}\right): \delta 166.3,166.0,143.9,142.3,136.7,135.3$, 130.0, 128.2, 127.4, 124.0, 52.2, 51.8, 49.2, 48.2, 21.7; HRMS (m/z) $[\mathrm{M}+\mathrm{H}]^{+}$calc'd for $\mathrm{C}_{17} \mathrm{H}_{22} \mathrm{NO}_{6} \mathrm{~S}$, 368.1162 , found 368.1150 .

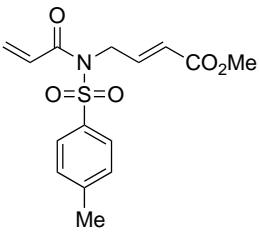

3: In a $100 \mathrm{~mL}$ flask, a mixture of methyl (E)-4-((4-methylphenyl)sulfon amido)but-2-enoate $\mathbf{S 2}(1.0 \mathrm{~g}, 3.7 \mathrm{mmol})$ and triethylamine $(1.6 \mathrm{~mL}, 11.1 \mathrm{mmol})$ in $20 \mathrm{~mL}$ of DCM was stirred in ice bath. The acryloyl chloride $(0.91 \mathrm{~mL}, 11.1$ $\mathrm{mmol}$ ) was slowly added and the mixture was stirred at room temperature for $12 \mathrm{~h}$. The reaction was quenched with saturate sodium bicarbonate solution and extracted with DCM $(3 \times 30 \mathrm{~mL})$. The combined organic layers were washed with brine $(30 \mathrm{~mL})$, dried over $\mathrm{Na}_{2} \mathrm{SO}_{4}$ and concentrated in vacuo. The crude material was purified by flash column chromatography to give a white solid $(0.67 \mathrm{~g}, 56 \%$ yield $) .{ }^{1} \mathrm{H} \mathrm{NMR}\left(600 \mathrm{MHz}, \mathrm{CDCl}_{3}\right): \delta 7.76(\mathrm{~d}$, $J=8.4 \mathrm{~Hz}, 2 \mathrm{H}), 7.34(\mathrm{~d}, J=8.0 \mathrm{~Hz}, 2 \mathrm{H}), 6.98-6.85(\mathrm{~m}, 2 \mathrm{H}), 6.39(\mathrm{dd}, J=16.7,1.5 \mathrm{~Hz}, 1 \mathrm{H}), 5.97$ $(\mathrm{dt}, J=15.7,1.7 \mathrm{~Hz}, 1 \mathrm{H}), 5.80(\mathrm{dd}, J=10.4,1.6 \mathrm{~Hz}, 1 \mathrm{H}), 4.60(\mathrm{dd}, J=5.3,1.7 \mathrm{~Hz}, 2 \mathrm{H}), 3.73(\mathrm{~s}$, 3H), 2.44 (s, 3H); $\left.{ }^{13} \mathrm{C} \mathrm{NMR} \mathrm{(150} \mathrm{MHz,} \mathrm{CDCl}_{3}\right): \delta 166.2,165.4,145.5,142.1,136.5,132.3,130.1$, 128.2, 127.8, 123.4, 51.8, 46.9, 21.8; HRMS (m/z) $[\mathrm{M}+\mathrm{H}]^{+}$calc'd for $\mathrm{C}_{15} \mathrm{H}_{18} \mathrm{NO}_{5} \mathrm{~S}, 324.0900$, found 324.0910 . 
Scheme S2. Synthesis of model compound 4.
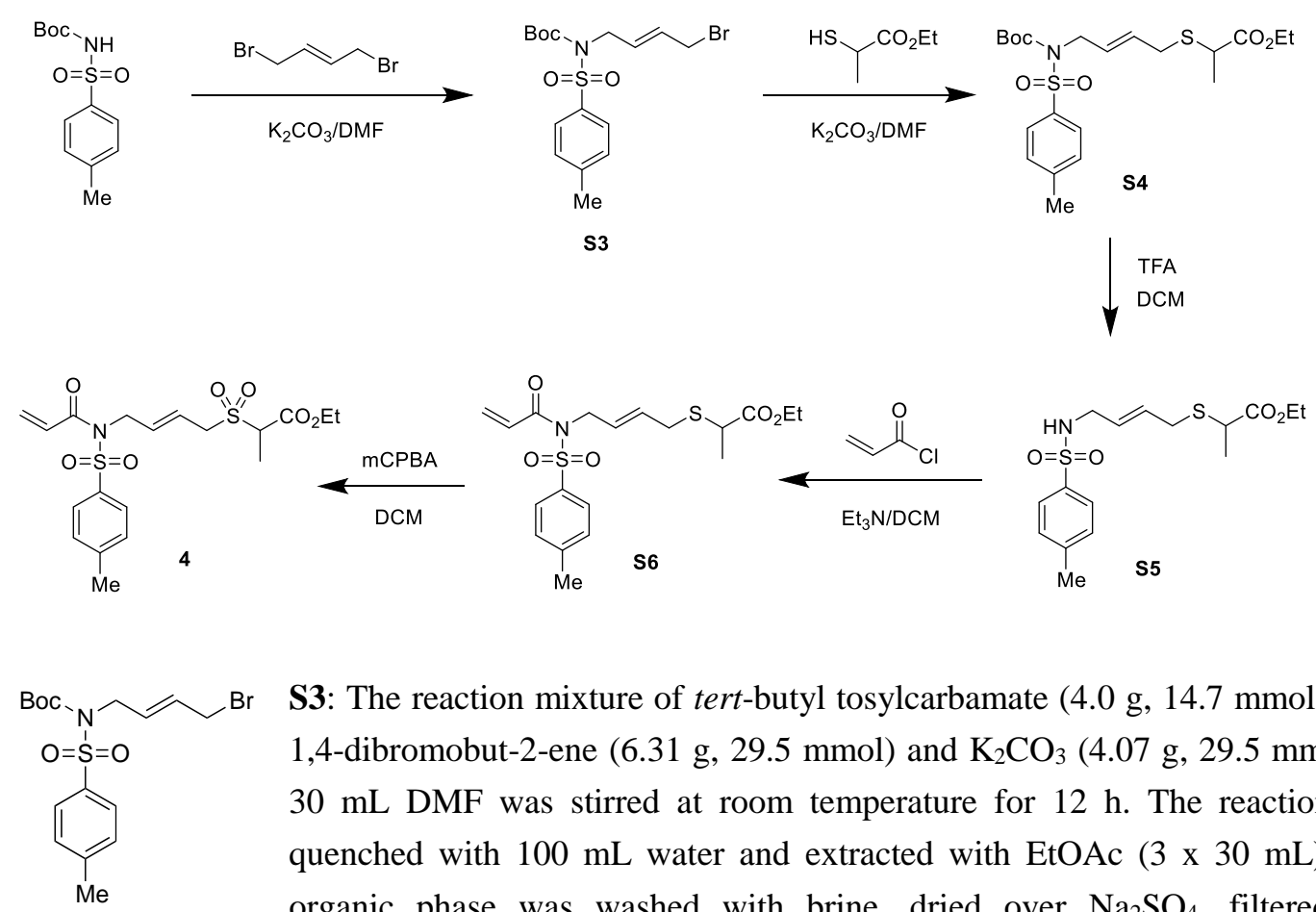

S3: The reaction mixture of tert-butyl tosylcarbamate $(4.0 \mathrm{~g}, 14.7 \mathrm{mmol}),(E)$ 1,4-dibromobut-2-ene $(6.31 \mathrm{~g}, 29.5 \mathrm{mmol})$ and $\mathrm{K}_{2} \mathrm{CO}_{3}(4.07 \mathrm{~g}, 29.5 \mathrm{mmol})$ in $30 \mathrm{~mL}$ DMF was stirred at room temperature for $12 \mathrm{~h}$. The reaction was quenched with $100 \mathrm{~mL}$ water and extracted with EtOAc $(3 \times 30 \mathrm{~mL})$. The organic phase was washed with brine, dried over $\mathrm{Na}_{2} \mathrm{SO}_{4}$, filtered and concentrated under vacuum. The residue was was purified by column chromatography to afford a colorless solid $\mathbf{S 3}$ (4.82 g, 81\% yield). ${ }^{1} \mathrm{H}$ NMR $\left(600 \mathrm{MHz}, \mathrm{CDCl}_{3}\right): \delta 7.80(\mathrm{~d}, J=8.3 \mathrm{~Hz}, 2 \mathrm{H}), 7.30$ $(\mathrm{d}, J=7.9 \mathrm{~Hz}, 2 \mathrm{H}), 5.98(\mathrm{dt}, J=15.1,7.5 \mathrm{~Hz}, 1 \mathrm{H}), 5.87(\mathrm{dt}, J=15.2,6.1 \mathrm{~Hz}, 1 \mathrm{H}), 4.45(\mathrm{~d}, J=5.7$ $\mathrm{Hz}, 2 \mathrm{H}), 3.97$ (d, $J=8.2 \mathrm{~Hz}, 2 \mathrm{H}), 2.44(\mathrm{~s}, 3 \mathrm{H}), 1.35$ (s, 9H); ${ }^{13} \mathrm{C}$ NMR $\left(150 \mathrm{MHz}, \mathrm{CDCl}_{3}\right): \delta 150.7$, 144.4, 137.1, 130.2, 129.4, 128.3, 84.7, 47.3, 31.8, 28.0, 21.8; HRMS $(\mathrm{m} / \mathrm{z})[\mathrm{M}+\mathrm{H}]^{+}$calc'd for $\mathrm{C}_{16} \mathrm{H}_{23} \mathrm{NO}_{4} \mathrm{SBr}, 404.0526$, found 404.0528 .

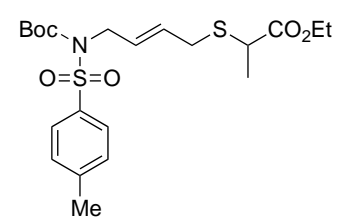

S4: To a well-stirred solution of $\mathbf{S 3}(1.65 \mathrm{~g}, 4.1 \mathrm{mmol})$ and $\mathrm{K}_{2} \mathrm{CO}_{3}(1.13 \mathrm{~g}$, $8.2 \mathrm{~mol}$ ) in $30 \mathrm{~mL}$ DMF, ethyl 2-mercaptopropionate (547.7 mg, $4.1 \mathrm{mmol}$ ) was added. The reaction was stirred at room temperature for $12 \mathrm{~h}$. The reaction was acidified with $1 \mathrm{M}$ aq. $\mathrm{HCl}$ and extracted with EtOAc $(3 \times 30$ $\mathrm{mL}$ ). The organic phase was washed with brine, dried over $\mathrm{Na}_{2} \mathrm{SO}_{4}$, filtered and concentrated under vacuum. The residue was purified by column chromatography to afford a colorless oil $\mathbf{S 4}\left(1.61 \mathrm{~g}, 86 \%\right.$ yield). ${ }^{1} \mathrm{H}$ NMR $\left(600 \mathrm{MHz}, \mathrm{CDCl}_{3}\right): \delta 7.78(\mathrm{~d}, J=8.4 \mathrm{~Hz}, 2 \mathrm{H}), 7.29$ $(\mathrm{d}, J=8.0 \mathrm{~Hz}, 2 \mathrm{H}), 5.81-5.70(\mathrm{~m}, 2 \mathrm{H}), 4.42(\mathrm{~d}, J=5.0 \mathrm{~Hz}, 2 \mathrm{H}), 4.19$ (qq, $J=10.8,7.1 \mathrm{~Hz}, 2 \mathrm{H})$, $3.41-3.31(\mathrm{~m}, 2 \mathrm{H}), 3.20(\mathrm{dd}, J=13.5,4.5 \mathrm{~Hz}, 1 \mathrm{H}), 2.43(\mathrm{~s}, 3 \mathrm{H}), 1.40(\mathrm{~d}, J=7.2 \mathrm{~Hz}, 3 \mathrm{H}), 1.33$ (s, 9H), 1.29 (t, $J=7.1 \mathrm{~Hz}, 3 \mathrm{H}) ;{ }^{13} \mathrm{C}$ NMR $\left(150 \mathrm{MHz}, \mathrm{CDCl}_{3}\right): \delta 173.2,150.8,144.3,137.4,129.7$, $129.4,128.7,128.2,84.4,61.2,47.8,39.9,33.3,28.0,21.8,17.1,14.4 ;$ HRMS (m/z) $[\mathrm{M}+\mathrm{H}]^{+}$calc'd for $\mathrm{C}_{21} \mathrm{H}_{32} \mathrm{NO}_{6} \mathrm{~S}_{2}, 458.1666$, found 458.1663 .

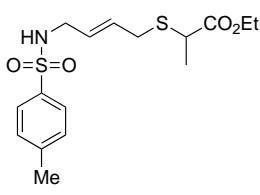

S5: To a well-stirred solution of $\mathbf{S 4}(1.56 \mathrm{~g}, 3.4 \mathrm{mmol})$ in $20 \mathrm{~mL}$ DCM at $0{ }^{\circ} \mathrm{C}$, TFA ( $1.3 \mathrm{~mL}, 17.1 \mathrm{mmol})$ was added dropwise and the reaction was stirred for 24 hours at room temperature. The reaction was quenched with saturate sodium bicarbonate solution and extracted with DCM $(3 \times 30 \mathrm{~mL})$. The organic phase 
was washed with brine, dried over $\mathrm{Na}_{2} \mathrm{SO}_{4}$, filtered and concentrated under vacuum. The residue was purified by column chromatography to afford the product as a colorless oil $\mathbf{S 5}(1.20 \mathrm{~g}, 98 \%)$. ${ }^{1} \mathrm{H}$ NMR $\left(600 \mathrm{MHz}, \mathrm{CDCl}_{3}\right): \delta 7.74(\mathrm{~d}, J=8.3 \mathrm{~Hz}, 2 \mathrm{H}), 7.31(\mathrm{~d}, J=7.9 \mathrm{~Hz}, 2 \mathrm{H}), 5.60-5.47(\mathrm{~m}$, 2H), $4.67(\mathrm{br}, 1 \mathrm{H}), 4.24-4.08(\mathrm{~m}, 2 \mathrm{H}), 3.55(\mathrm{t}, J=5.9 \mathrm{~Hz}, 2 \mathrm{H}), 3.32-3.17(\mathrm{~m}, 2 \mathrm{H}), 3.09$ (dd, $J=$ 14.2, $6.6 \mathrm{~Hz}, 1 \mathrm{H}), 2.42(\mathrm{~s}, 3 \mathrm{H}), 1.38(\mathrm{~d}, J=7.2 \mathrm{~Hz}, 3 \mathrm{H}), 1.26(\mathrm{t}, J=7.1 \mathrm{~Hz}, 3 \mathrm{H}) .{ }^{13} \mathrm{C}$ NMR $(150$ $\left.\mathrm{MHz}, \mathrm{CDCl}_{3}\right): \delta 173.2,143.6,137.0,129.9,129.5,128.3,127.3,61.3,44.9,40.2,33.1,21.7,17.1$, 14.3; HRMS (m/z) $[\mathrm{M}+\mathrm{H}]^{+}$calc'd for $\mathrm{C}_{16} \mathrm{H}_{24} \mathrm{NO}_{4} \mathrm{~S}_{2}, 358.1141$, found 358.1125 .

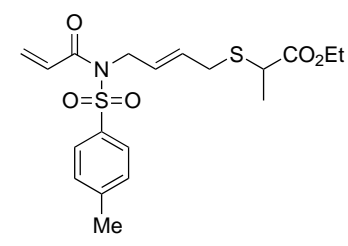

S6: In a $100 \mathrm{~mL}$ flask, a mixture of $\mathbf{S 5}(600 \mathrm{mg}, 1.7 \mathrm{mmol})$ and triethylamine $(1.2 \mathrm{~mL}, 8.4 \mathrm{mmol})$ in $20 \mathrm{~mL}$ of DCM was stirred in ice bath. The acryloyl chloride $(0.68 \mathrm{~mL}, 8.4 \mathrm{mmol})$ was slowly added and the mixture was stirred at room temperature for $15 \mathrm{~h}$. The reaction was quenched with saturate sodium bicarbonate solution and extracted with DCM $(3 \times 30 \mathrm{~mL})$. The combined organic layers were washed with brine $(30 \mathrm{~mL})$, dried over $\mathrm{Na}_{2} \mathrm{SO}_{4}$ and concentrated in vacuo. The crude material was purified by flash column chromatography to give a colorless oil $\mathbf{S 6}$ (405 mg, 59\% yield). ${ }^{1} \mathrm{H} \mathrm{NMR}\left(500 \mathrm{MHz}, \mathrm{CDCl}_{3}\right): \delta 7.79$ $(\mathrm{d}, J=8.0 \mathrm{~Hz}, 2 \mathrm{H}), 7.32(\mathrm{~d}, J=8.3 \mathrm{~Hz}, 2 \mathrm{H}), 6.88(\mathrm{dd}, J=16.7,10.4 \mathrm{~Hz}, 1 \mathrm{H}), 6.36(\mathrm{~d}, J=17.0 \mathrm{~Hz}$, 1H), $5.72(\mathrm{ddd}, J=19.3,14.9,10.5 \mathrm{~Hz}, 3 \mathrm{H}), 4.46(\mathrm{~d}, J=4.8 \mathrm{~Hz}, 2 \mathrm{H}), 4.18(\mathrm{p}, J=6.7 \mathrm{~Hz}, 2 \mathrm{H}), 3.32$ (dq, $J=13.3,7.2 \mathrm{~Hz}, 2 \mathrm{H}), 3.17$ (dd, $J=13.4,5.3 \mathrm{~Hz}, 1 \mathrm{H}), 2.43(\mathrm{~s}, 3 \mathrm{H}), 1.40(\mathrm{~d}, J=7.2 \mathrm{~Hz}, 3 \mathrm{H})$, $1.28(\mathrm{t}, J=7.1 \mathrm{~Hz}, 3 \mathrm{H}) ;{ }^{13} \mathrm{C}$ NMR $\left(125 \mathrm{MHz}, \mathrm{CDCl}_{3}\right): \delta 173.2,165.5,145.1,136.8,131.6,130.1$, 129.9, 128.5, 128.0, 127.9, 61.3, 47.6, 40.1, 33.2, 21.8, 17.1, 14.3; HRMS (m/z) $[\mathrm{M}+\mathrm{H}]^{+}$calc'd for $\mathrm{C}_{19} \mathrm{H}_{26} \mathrm{NO}_{5} \mathrm{~S}_{2}, 412.1247$, found 412.1248 .

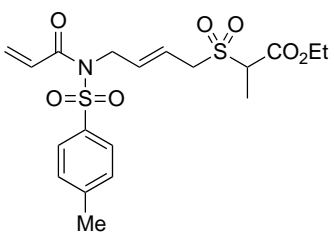

4: The compound $\mathbf{S 6}$ (330 mg, $0.8 \mathrm{mmol}$ ) was dissolved in DCM (15 mL), and $77 \%$ mCPBA (540 mg, $2.4 \mathrm{mmol}$ ) was added. After stirring for $1 \mathrm{~h}$ at room temperature, the reaction was quenched with saturate sodium bicarbonate solution and extracted with DCM $(3 \times 30 \mathrm{~mL})$. The combined organic layers were washed with brine $(30 \mathrm{~mL})$ and concentrated in vacuo.

The residue was purified by flash column chromatography to give the colorless oil 4 (290 mg, 82\% yield). ${ }^{1} \mathrm{H}$ NMR (500 MHz, $\left.\mathrm{CDCl}_{3}\right): \delta 7.78(\mathrm{~d}, J=8.3 \mathrm{~Hz}, 2 \mathrm{H}), 7.34(\mathrm{~d}, J=8.3 \mathrm{~Hz}, 2 \mathrm{H}), 6.92(\mathrm{dd}$, $J=16.7,10.4 \mathrm{~Hz}, 1 \mathrm{H}), 6.37(\mathrm{~d}, J=16.7 \mathrm{~Hz}, 1 \mathrm{H}), 6.04(\mathrm{dt}, J=15.3,5.8 \mathrm{~Hz}, 1 \mathrm{H}), 5.85(\mathrm{dt}, J=15.4$, $7.5 \mathrm{~Hz}, 1 \mathrm{H}), 5.78(\mathrm{~d}, J=10.4 \mathrm{~Hz}, 1 \mathrm{H}), 4.51(\mathrm{q}, J=8.4,6.3 \mathrm{~Hz}, 2 \mathrm{H}), 4.28(\mathrm{qd}, J=7.1,2.3 \mathrm{~Hz}, 2 \mathrm{H})$, $4.09(\mathrm{dd}, J=13.9,8.3 \mathrm{~Hz}, 1 \mathrm{H}), 4.02(\mathrm{q}, J=7.3 \mathrm{~Hz}, 1 \mathrm{H}), 3.83(\mathrm{dd}, J=13.9,6.6 \mathrm{~Hz}, 1 \mathrm{H}), 2.44(\mathrm{~s}$, $3 \mathrm{H}), 1.60(\mathrm{~d}, J=7.3 \mathrm{~Hz}, 3 \mathrm{H}), 1.33(\mathrm{t}, J=7.1 \mathrm{~Hz}, 3 \mathrm{H}) ;{ }^{13} \mathrm{C} \mathrm{NMR}\left(125 \mathrm{MHz}, \mathrm{CDCl}_{3}\right): \delta 166.5,165.5$, 145.4, 136.5, 135.8, 131.9, 130.2, 128.4, 127.8, 120.3, 62.7, 60.9, 55.5, 47.5, 21.8, 14.1, 9.8; HRMS $(\mathrm{m} / \mathrm{z})[\mathrm{M}+\mathrm{H}]^{+}$calc'd for $\mathrm{C}_{19} \mathrm{H}_{26} \mathrm{NO}_{7} \mathrm{~S}_{2}, 444.1145$, found 444.1160 . 
Scheme S3. General procedure for synthesis of $\alpha$-methyl allylsulfone-containing macrocyclic monomers.
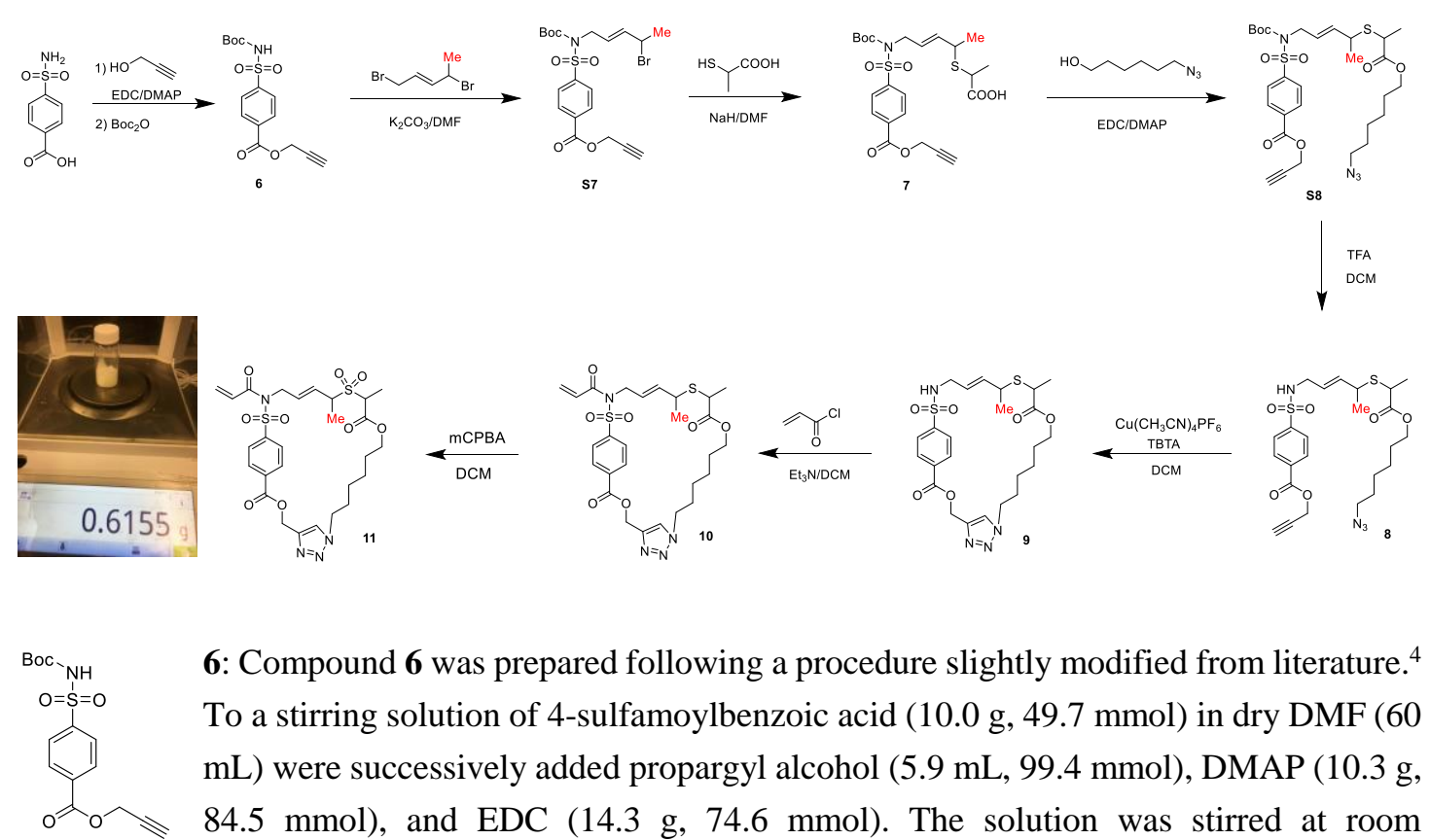

6: Compound 6 was prepared following a procedure slightly modified from literature. ${ }^{4}$ To a stirring solution of 4-sulfamoylbenzoic acid (10.0 g, $49.7 \mathrm{mmol}$ ) in dry DMF (60 $\mathrm{mL})$ were successively added propargyl alcohol $(5.9 \mathrm{~mL}, 99.4 \mathrm{mmol})$, DMAP $(10.3 \mathrm{~g}$, $84.5 \mathrm{mmol})$, and $\operatorname{EDC}(14.3 \mathrm{~g}, 74.6 \mathrm{mmol})$. The solution was stirred at room temperature for $36 \mathrm{~h}$. The reaction was quenched with $100 \mathrm{~mL}$ water and extracted with ethyl acetate $(30 \mathrm{~mL} \times 5)$. The organic phase was washed with saturated aqueous $\mathrm{NaHCO}_{3}(50 \mathrm{~mL} \times 2)$, $1 \mathrm{M}$ aq. $\mathrm{HCl}(50 \mathrm{~mL} \times 2)$ and brine $(50 \mathrm{~mL})$, dried over $\mathrm{Na}_{2} \mathrm{SO}_{4}$, filtered and concentrated in vacuo. The residue was purified by recrystallization (DCM/hexane) to affore the product as yellow solid $(9.0 \mathrm{~g})$. A mixture of yellow solid $(9.0 \mathrm{~g}, 37.6 \mathrm{mmol})$ and Boc anhydride $(9.85 \mathrm{~g}, 45.1 \mathrm{mmol})$ in 40 $\mathrm{mL}$ of DCM was stirred in ice bath. The triethylamine $(5.8 \mathrm{~mL}, 41.4 \mathrm{mmol})$ and 4dimethylaminopyridine ( $460 \mathrm{mg}, 3.8 \mathrm{mmol}$ ) was slowly added and the mixture was stirred at room temperature for $12 \mathrm{~h}$. The reaction was quenched with $1 \mathrm{M}$ aq. $\mathrm{HCl}$ and extracted with DCM $(3 \times 30$ $\mathrm{mL})$. The combined organic layers were washed with brine $(30 \mathrm{~mL})$ and concentrated in vacuo. The crude material was purified by flash column chromatography to give a colorless solid $\mathbf{5}$ (12.8 g, 73\% total yield). ${ }^{1} \mathrm{H}$ NMR (600 MHz, $\left.\mathrm{CDCl}_{3}\right): \delta 8.18(\mathrm{~d}, J=8.5 \mathrm{~Hz}, 2 \mathrm{H}), 8.07(\mathrm{~d}, J=8.5 \mathrm{~Hz}, 2 \mathrm{H}), 4.92$ $(\mathrm{d}, J=2.4 \mathrm{~Hz}, 2 \mathrm{H}), 2.54(\mathrm{t}, J=2.4 \mathrm{~Hz}, 1 \mathrm{H}), 1.32(\mathrm{~s}, 9 \mathrm{H}) ;{ }^{13} \mathrm{C} \mathrm{NMR}\left(150 \mathrm{MHz}, \mathrm{CDCl}_{3}\right): \delta 164.4$, $149.2,143.2,133.9,130.3,128.3,84.6,77.1,75.8,53.2,27.8 ;$ HRMS $(\mathrm{m} / \mathrm{z})[\mathrm{M}+\mathrm{H}]^{+}$calc'd for $\mathrm{C}_{15} \mathrm{H}_{18} \mathrm{NO}_{6} \mathrm{~S}, 340.0849$, found 340.0847 .

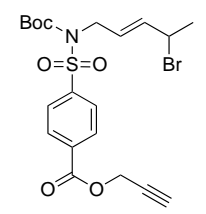

S7: The reaction mixture of prop-2-yn-1-yl 4-( $N$-(tert-butoxycarbonyl)sulfamoyl) benzoate $(9.0 \mathrm{~g}, 26.5 \mathrm{~mol}),(E)-1,4$-dibromopent-2-ene $(7.86 \mathrm{~g}, 34.5 \mathrm{mmol})$ and $\mathrm{K}_{2} \mathrm{CO}_{3}(7.33 \mathrm{~g}, 53.0 \mathrm{~mol})$ in $30 \mathrm{~mL}$ DMF was stirred at room temperature for $12 \mathrm{~h}$. The reaction was quenched with $50 \mathrm{~mL}$ water and extracted with EtOAc $(3 \times 30 \mathrm{~mL})$. The organic phase was washed with brine, dried over $\mathrm{Na}_{2} \mathrm{SO}_{4}$, filtered and concentrated under vacuum. The residue was purified by column chromatography to afford a colorless oil $\mathbf{S 7}(9.13 \mathrm{~g}$, $71 \%$ yield). ${ }^{1} \mathrm{H}$ NMR (600 MHz, $\left.\mathrm{CDCl}_{3}\right) \delta 8.19(\mathrm{~d}, J=8.7 \mathrm{~Hz}, 2 \mathrm{H}), 8.01(\mathrm{~d}, J=8.7 \mathrm{~Hz}, 2 \mathrm{H}), 6.02$ $(\mathrm{dd}, J=15.3,8.5 \mathrm{~Hz}, 1 \mathrm{H}), 5.75(\mathrm{dt}, J=15.9,6.3 \mathrm{~Hz}, 1 \mathrm{H}), 4.95(\mathrm{~d}, J=2.5 \mathrm{~Hz}, 2 \mathrm{H}), 4.69$ (p, $J=6.8$ $\mathrm{Hz}, 1 \mathrm{H}), 4.44(\mathrm{~d}, J=6.3 \mathrm{~Hz}, 2 \mathrm{H}), 2.54(\mathrm{t}, J=2.5 \mathrm{~Hz}, 1 \mathrm{H}), 1.79(\mathrm{~d}, J=6.7 \mathrm{~Hz}, 3 \mathrm{H}), 1.34(\mathrm{~s}, 9 \mathrm{H})$. ${ }^{13} \mathrm{C}$ NMR $\left(150 \mathrm{MHz}, \mathrm{CDCl}_{3}\right) \delta 164.4,150.4,144.2,137.3,133.7,130.2,128.4,125.7,85.3,77.2$, 75.7, 53.3, 47.9, 47.3, 28.0, 25.8; HRMS (m/z) $\left[\mathrm{M}+\mathrm{NH}_{4}\right]^{+}$calc'd for $\mathrm{C}_{20} \mathrm{H}_{28} \mathrm{~N}_{2} \mathrm{O}_{6} \mathrm{SBr}$, 503.0846, 
found 503.0837 .

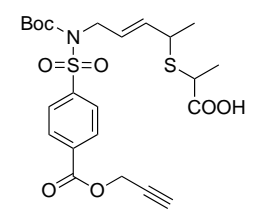

7: To a well-stirred solution of 2-mercaptopropionic acid $(825 \mathrm{mg}, 7.8 \mathrm{mmol})$ in $15 \mathrm{~mL}$ DMF, sodium hydride (592 mg, $14.8 \mathrm{mmol}, 60 \%$ dispersion in mineral oil) was added and stirred at $0{ }^{\circ} \mathrm{C}$ for $5 \mathrm{~min}$. Followed by addition $20 \mathrm{~mL} \mathrm{DMF}$ of $\mathbf{S 7}$ (3.6 g, $7.4 \mathrm{mmol}$ ) solution. The reaction was stirred at room temperature for $12 \mathrm{~h}$. The reaction was acidified with $1 \mathrm{M}$ aq. $\mathrm{HCl}$ and extracted with EtOAc $(3 \times 30 \mathrm{~mL})$. The organic phase was washed with brine, dried over $\mathrm{Na}_{2} \mathrm{SO}_{4}$, filtered and concentrated under vacuum. The residue was was purified by column chromatography to afford a colorless oil 6 ( $3.25 \mathrm{~g}, 86 \%$ yield). ${ }^{1} \mathrm{H}$ NMR (600 MHz, $\left.\mathrm{CDCl}_{3}\right): \delta 8.20(\mathrm{~d}, J=8.8 \mathrm{~Hz}, 2 \mathrm{H}$ ), 8.00 (dd, $J=8.8,2.3 \mathrm{~Hz}, 2 \mathrm{H}), 5.79-5.55$ (m, 2H), 5.00-4.93 (m, 2H), 4.49-4.40 (m, 2H), 3.69-3.56 (m, 1H), $3.47(\mathrm{q}, J=7.1 \mathrm{~Hz}, 1 \mathrm{H}), 2.56$ $(\mathrm{t}, J=2.5 \mathrm{~Hz}, 1 \mathrm{H}), 1.48(\mathrm{~d}, J=7.2 \mathrm{~Hz}, 1.5 \mathrm{H}), 1.40(\mathrm{dd}, J=7.0,3.9 \mathrm{~Hz}, 3 \mathrm{H}), 1.34(\mathrm{~d}, J=1.6 \mathrm{~Hz}$, 9H), $1.31(\mathrm{~d}, J=7.0 \mathrm{~Hz}, 1.5 \mathrm{H}) ;{ }^{13} \mathrm{C} \mathrm{NMR}\left(150 \mathrm{MHz}, \mathrm{CDCl}_{3}\right): \delta 179.4,178.5,164.4,164.4,150.5$, 150.5, 144.5, 144.4, 136.3, 136.0, 133.7, 133.7, 130.2, 128.2, 128.2, 126.0, 125.6, 85.3, 85.2, 77.2, $75.8,75.8,53.3,47.9,47.8,42.3,42.0,40.9,39.7,28.0,28.0,20.6,19.9,17.8,16.6$; HRMS (m/z) $\left[\mathrm{M}+\mathrm{NH}_{4}\right]^{+}$calc'd for $\mathrm{C}_{23} \mathrm{H}_{33} \mathrm{~N}_{2} \mathrm{O}_{8} \mathrm{~S}_{2}, 529.1673$, found 529.1685 .

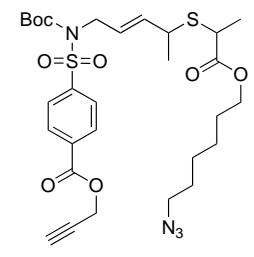

S8: In a $100 \mathrm{~mL}$ flask, a mixture of $7(3.23 \mathrm{~g}, 6.3 \mathrm{mmol})$, EDC hydrochloride $(1.82 \mathrm{~g}, 9.5 \mathrm{mmol})$ and 6-azidohexan-1-ol (1.36 g, $9.5 \mathrm{mmol})$ in $30 \mathrm{~mL}$ of DCM was stirred in ice bath. The 4-dimethylaminopyridine $(1.31 \mathrm{~g}, 10.7 \mathrm{mmol})$ was slowly added and the mixture was stirred at room temperature for $12 \mathrm{~h}$. The reaction was quenched with $1 \mathrm{M}$ aq. $\mathrm{HCl}$ and extracted with $\mathrm{DCM}(3 \times 30 \mathrm{~mL})$.

The combined organic layers were washed with brine $(30 \mathrm{~mL})$ and concentrated in vacuo. The crude material was purified by flash column chromatography to give a colorless oil $\mathbf{S 8}$ ( $2.95 \mathrm{~g}, 73 \%$ yield). ${ }^{1} \mathrm{H}$ NMR $\left(500 \mathrm{MHz}, \mathrm{CDCl}_{3}\right): \delta 8.18(\mathrm{dd}, J=8.5,1.8 \mathrm{~Hz}, 2 \mathrm{H}), 7.99(\mathrm{dd}, J=8.6,3.5 \mathrm{~Hz}, 2 \mathrm{H}), 5.88$ $5.53(\mathrm{~m}, 2 \mathrm{H}), 4.95(\mathrm{~d}, J=2.4 \mathrm{~Hz}, 2 \mathrm{H}), 4.43(\mathrm{dd}, J=11.1,6.1 \mathrm{~Hz}, 2 \mathrm{H}), 4.13(\mathrm{dt}, J=17.7,6.6 \mathrm{~Hz}$, $2 \mathrm{H}), 3.55(\mathrm{dt}, J=14.1,7.0 \mathrm{~Hz}, 1 \mathrm{H}), 3.42(\mathrm{q}, J=7.1 \mathrm{~Hz}, 0.5 \mathrm{H}), 3.32-3.21(\mathrm{~m}, 2.5 \mathrm{H}), 2.55(\mathrm{t}, J=2.4$ $\mathrm{Hz}, 1 \mathrm{H}), 1.74-1.55(\mathrm{~m}, 4 \mathrm{H}), 1.50-1.26(\mathrm{~m}, 19 \mathrm{H}) ;{ }^{13} \mathrm{C} \mathrm{NMR}\left(125 \mathrm{MHz}, \mathrm{CDCl}_{3}\right): \delta 173.6,173.2$, 164.4, 150.4, 144.5, 144.4, 136.7, 136.5, 133.6, 130.2, 129.9, 128.2, 128.2, 125.7, 125.3, 85.1, 85.0, 75.7, 65.8, 65.2, 65.0, 53.3, 51.4, 47.9, 42.2, 41.3, 41.0, 40.2, 28.8, 28.6, 28.5, 28.0, 26.5, 25.6, 25.6, 20.6, 20.0, 18.1, 16.9; HRMS (m/z) $\left[\mathrm{M}+\mathrm{NH}_{4}\right]^{+}$calc'd for $\mathrm{C}_{29} \mathrm{H}_{44} \mathrm{~N}_{5} \mathrm{O}_{8} \mathrm{~S}_{2}, 654.2626$, found 654.2605.

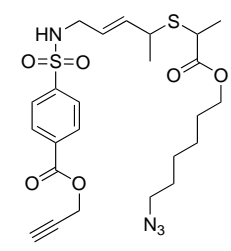

8: To a well-stirred solution of $\mathbf{S 8}(2.45 \mathrm{~g}, 3.9 \mathrm{mmol})$ in $20 \mathrm{~mL} \mathrm{DCM}$ at $0{ }^{\circ} \mathrm{C}$, TFA $(1.8 \mathrm{~mL}, 20.1 \mathrm{mmol})$ was added dropwise and the reaction was stirred for 36 hours at room temperature. The reaction was quenched with saturate sodium bicarbonate solution and extracted with DCM $(3 \times 30 \mathrm{~mL})$. The organic phase was washed with brine and concentrated under vacuum. The crude material was purified by flash column chromatography to give a white solid $8(1.45 \mathrm{~g}, 70 \%) .{ }^{1} \mathrm{H}$ NMR $\left(600 \mathrm{MHz}, \mathrm{CDCl}_{3}\right): \delta 8.20$ $(\mathrm{dd}, J=8.5,1.9 \mathrm{~Hz}, 2 \mathrm{H}), 7.96(\mathrm{dd}, J=8.4,1.7 \mathrm{~Hz}, 2 \mathrm{H}), 5.50-5.36(\mathrm{~m}, 2 \mathrm{H}), 5.19(\mathrm{br}, 0.5 \mathrm{H}), 4.96(\mathrm{~d}$, $J=2.4 \mathrm{~Hz}, 2 \mathrm{H}), 4.91(\mathrm{br}, 0.5 \mathrm{H}), 4.15-4.02(\mathrm{~m}, 2 \mathrm{H}), 3.61(\mathrm{t}, J=5.5 \mathrm{~Hz}, 1 \mathrm{H}), 3.54-3.36(\mathrm{~m}, 2 \mathrm{H})$, $3.30-3.13(\mathrm{~m}, 3 \mathrm{H}), 2.55(\mathrm{t}, J=2.4 \mathrm{~Hz}, 1 \mathrm{H}), 1.70-1.54(\mathrm{~m}, 4 \mathrm{H}), 1.44-1.33(\mathrm{~m}, 7 \mathrm{H}), 1.21(\mathrm{dd}, J=$ $27.0,6.9 \mathrm{~Hz}, 3 \mathrm{H}) ;{ }^{13} \mathrm{C} \mathrm{NMR}\left(150 \mathrm{MHz}, \mathrm{CDCl}_{3}\right): \delta 173.8,173.6,164.5,164.4,144.6,144.6,137.0$, $136.1,133.3,133.2,130.7,130.7,127.3,125.3,124.9,77.3,77.2,75.7,75.7,65.3,65.1,53.2,51.4$, 45.0, 44.9, 42.8, 42.2, 41.7, 40.2, 28.8, 28.6, 28.5, 26.4, 26.4, 25.6, 25.5, 20.2, 19.9, 18.4, 17.0; HRMS (m/z) $[\mathrm{M}+\mathrm{H}]^{+}$calc'd for $\mathrm{C}_{24} \mathrm{H}_{33} \mathrm{~N}_{4} \mathrm{O}_{6} \mathrm{~S}_{2}, 537.1836$, found 537.1834 . 


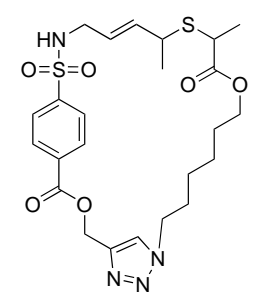

9: Compound $\mathbf{9}$ was prepared following a procedure slightly modified from literature. ${ }^{5}$ In a $500 \mathrm{~mL}$ round-bottom pressure flask, $8(1.45 \mathrm{~g})$ was dissolved in dry DCM $(300 \mathrm{~mL})$, the solution was degassed by nitrogen for $15 \mathrm{~min}$. To this solution was added TBTA (79.1 mg) and tetrakis(acetonitrile)copper(I) hexafluorophosphate $(55.6 \mathrm{mg})$. The reaction mixture was flushed with nitrogen and stirred at $55{ }^{\circ} \mathrm{C}$ for $36 \mathrm{~h}$. The reaction mixture was cooled to room temperature and quenched with methanol, then concentrated under vacuum. The crude material was purified by flash column chromatography to give a white solid 9 (1.03 g, 71\% yield). ${ }^{1} \mathrm{H}$ NMR (600 $\left.\mathrm{MHz}, \mathrm{CDCl}_{3}\right) \delta 8.13(\mathrm{~d}, J=7.6 \mathrm{~Hz}, 2 \mathrm{H}), 7.94(\mathrm{dd}, J=8.7,1.9 \mathrm{~Hz}, 2 \mathrm{H}), 7.70(\mathrm{~d}, J=6.6 \mathrm{~Hz}, 1 \mathrm{H})$, $5.58-5.46(\mathrm{~m}, 2 \mathrm{H}), 5.41-5.19(\mathrm{~m}, 2.5 \mathrm{H}), 5.07(\mathrm{dt}, J=15.1,6.5 \mathrm{~Hz}, 0.5 \mathrm{H}), 4.45-4.34(\mathrm{~m}, 2 \mathrm{H}), 3.97-$ $3.79(\mathrm{~m}, 2 \mathrm{H}), 3.72(\mathrm{t}, J=6.1 \mathrm{~Hz}, 1 \mathrm{H}), 3.69-3.62(\mathrm{~m}, 0.5 \mathrm{H}), 3.45-3.37(\mathrm{~m}, 0.5 \mathrm{H}), 3.31$ (quint, $J=$ $6.9 \mathrm{~Hz}, 0.5 \mathrm{H}$ ), $3.13(\mathrm{dq}, J=14.4,7.1 \mathrm{~Hz}, 1 \mathrm{H}), 2.93$ (q, $J=7.3 \mathrm{~Hz}, 0.5 \mathrm{H}), 1.85$ (sext, $J=7.0 \mathrm{~Hz}$, 2H), $1.43(\mathrm{tt}, J=9.8,5.0 \mathrm{~Hz}, 2 \mathrm{H}), 1.32(\mathrm{~d}, J=7.2 \mathrm{~Hz}, 1.5 \mathrm{H}), 1.26-1.07(\mathrm{~m}, 7 \mathrm{H}), 0.94(\mathrm{~d}, J=7.0$ $\mathrm{Hz}, 1.5 \mathrm{H}) ;{ }^{13} \mathrm{C} \mathrm{NMR}\left(150 \mathrm{MHz}, \mathrm{CDCl}_{3}\right) \delta 173.6,173.1,165.0,145.4,144.3,142.8,142.7,136.9$, 135.9, 133.6, 133.5, 130.5, 130.5, 127.4, 127.3, 125.0, 124.6, 124.5, 124.4, 64.9, 64.6, 58.5, 58.4, 50.6, 50.6, 45.4, 44.9, 42.2, 41.6, 41.5, 40.1, 30.0, 30.0, 28.4, 28.3, 26.2, 26.0, 25.3, 25.3, 20.0, 19.7, 18.3, 16.7; HRMS (m/z) $[\mathrm{M}+\mathrm{H}]^{+}$calc'd for $\mathrm{C}_{24} \mathrm{H}_{33} \mathrm{~N}_{4} \mathrm{O}_{6} \mathrm{~S}_{2}, 537.1836$, found 537.1835.

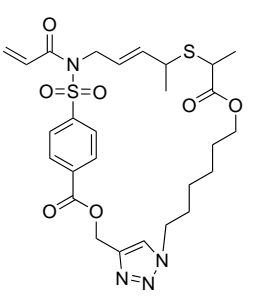

10: In a $100 \mathrm{~mL}$ flask, a mixture of $9(1.03 \mathrm{~g}, 1.9 \mathrm{mmol})$ and triethylamine (1.4 $\mathrm{mL}, 9.6 \mathrm{mmol}$ ) in $20 \mathrm{~mL}$ of DCM was stirred in ice bath. The acryloyl chloride $(0.78 \mathrm{~mL}, 9.6 \mathrm{mmol})$ was slowly added and the mixture was stirred at room temperature for $15 \mathrm{~h}$. The reaction was quenched with saturate sodium bicarbonate solution and extracted with DCM $(3 \times 30 \mathrm{~mL})$. The combined organic layers were washed with brine $(30 \mathrm{~mL})$ and concentrated in vacuo. The crude material was purified by flash column chromatography to give a white solid $\mathbf{1 0}$ (753 $\mathrm{mg}, 66 \%$ yield). ${ }^{1} \mathrm{H}$ NMR (500 MHz, $\mathrm{CDCl}_{3}$ ): $\delta 8.13(\mathrm{dd}, J=12.1,8.7 \mathrm{~Hz}, 2 \mathrm{H}), 8.03(\mathrm{~d}, J=8.6 \mathrm{~Hz}, 2 \mathrm{H}), 7.68$ $(\mathrm{d}, J=7.1 \mathrm{~Hz}, 1 \mathrm{H}), 6.75(\mathrm{ddd}, J=18.9,16.7,10.4 \mathrm{~Hz}, 1 \mathrm{H}), 6.36(\mathrm{dt}, J=16.7,2.0 \mathrm{~Hz}, 1 \mathrm{H}), 5.78(\mathrm{~d}$, $J=10.4 \mathrm{~Hz}, 1 \mathrm{H}), 5.61-5.35(\mathrm{~m}, 4 \mathrm{H}), 4.62-4.29(\mathrm{~m}, 4 \mathrm{H}), 4.03-3.87(\mathrm{~m}, 2 \mathrm{H}), 3.46-3.38(\mathrm{~m}, 0.5 \mathrm{H})$, $3.32(\mathrm{q}, J=9.4,8.2 \mathrm{~Hz}, 1 \mathrm{H}), 3.02(\mathrm{q}, J=7.6 \mathrm{~Hz}, 0.5 \mathrm{H}), 1.87(\mathrm{dq}, J=12.8,6.9 \mathrm{~Hz}, 2 \mathrm{H}), 1.52(\mathrm{dq}, J$ $=16.8,10.1,8.4 \mathrm{~Hz}, 2 \mathrm{H}), 1.36(\mathrm{~d}, J=7.1 \mathrm{~Hz}, 1.5 \mathrm{H}), 1.30-1.21(\mathrm{~m}, 4 \mathrm{H}), 1.21-1.13(\mathrm{~m}, 2 \mathrm{H}), 1.11$ $(\mathrm{d}, J=7.0 \mathrm{~Hz}, 1.5 \mathrm{H}) ;{ }^{13} \mathrm{C} \mathrm{NMR}\left(125 \mathrm{MHz}, \mathrm{CDCl}_{3}\right): \delta 172.9,172.8,165.4,165.3,164.7,164.7$, 143.7, 143.4, 142.4, 142.3, 137.0, 136.7, 134.5, 134.5, 132.5, 132.4, 130.4, 130.4, 128.7, 128.4, 128.0, 127.9, 124.6, 124.3, 64.7, 64.5, 58.9, 58.8, 50.5, 50.4, 47.5, 47.2, 42.1, 40.7, 40.4, 29.9, 28.2, 25.8, 25.0, 20.6, 19.9, 17.7, 16.4; HRMS (m/z) $[\mathrm{M}+\mathrm{H}]^{+}$calc'd for $\mathrm{C}_{27} \mathrm{H}_{35} \mathrm{~N}_{4} \mathrm{O}_{7} \mathrm{~S}_{2}, 591.1942$, found 591.1931.

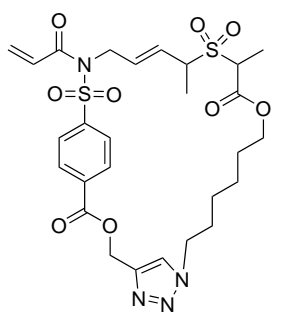

11: The compound $10(750 \mathrm{mg}, 1.27 \mathrm{mmol})$ was dissolved in DCM (15 mL), and $77 \%$ mCPBA ( $854 \mathrm{mg}, 3.81 \mathrm{mmol}$ ) was added. After stirring for $1 \mathrm{~h}$ at room temperature, the reaction was quenched with saturate sodium bicarbonate solution and extracted with DCM $(3 \times 30 \mathrm{~mL})$. The combined organic layers were washed with brine $(30 \mathrm{~mL})$ and concentrated in vacuo. The residue was purified by flash column chromatography to give the white solid $11(615 \mathrm{mg}$,

$78 \%$ yield). ${ }^{1} \mathrm{H} \mathrm{NMR}\left(600 \mathrm{MHz}, \mathrm{CDCl}_{3}\right): \delta 8.15(\mathrm{dd}, J=13.5,8.6 \mathrm{~Hz}, 2 \mathrm{H}), 8.02(\mathrm{dd}, J=22.7,8.6$ 
$\mathrm{Hz}, 2 \mathrm{H}), 7.69(\mathrm{~s}, 1 \mathrm{H}), 6.82-6.73(\mathrm{~m}, 1 \mathrm{H}), 6.35(\mathrm{dd}, J=16.6,4.7 \mathrm{~Hz}, 1 \mathrm{H}), 5.84-5.75(\mathrm{~m}, 2 \mathrm{H}), 5.70-$ $5.61(\mathrm{~m}, 1 \mathrm{H}), 5.53-5.44(\mathrm{~m}, 2 \mathrm{H}), 4.74-4.52(\mathrm{~m}, 2 \mathrm{H}), 4.41(\mathrm{qd}, J=16.4,16.0,7.4 \mathrm{~Hz}, 2 \mathrm{H}), 4.17-$ $3.88(\mathrm{~m}, 4 \mathrm{H}), 1.89$ (dq, $J=14.1,7.1 \mathrm{~Hz}, 2 \mathrm{H}), 1.63-1.47$ (m, 3H), 1.46-1.36 (m, 5H), 1.35-1.11 (m, $4 \mathrm{H}) ;{ }^{13} \mathrm{C}$ NMR (150 MHz, $\left.\mathrm{CDCl}_{3}\right): \delta 166.3,166.2,165.3,165.3,164.8,164.6,143.6,143.2,142.4$, $142.3,134.7,134.7,132.8,132.7,132.3,132.2,130.7,130.6,129.3,128.6,128.3,127.8,127.8$, $126.8,124.5,124.3,66.2,65.9,60.3,60.0,59.7,59.1,58.9,58.7,50.6,50.3,47.3,47.1,29.7,29.6$, 28.0, 27.7, 25.7, 25.6, 24.9, 24.8, 14.3, 12.1, 10.6, 8.7; HRMS $(\mathrm{m} / \mathrm{z})[\mathrm{M}+\mathrm{H}]^{+}$calc'd for $\mathrm{C}_{27} \mathrm{H}_{35} \mathrm{~N}_{4} \mathrm{O}_{9} \mathrm{~S}_{2}, 623.1840$, found 623.1820 .

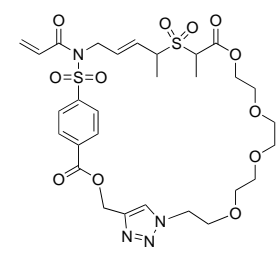

13: The monomer was prepared in similar yield according to the same procedure. ${ }^{1} \mathrm{H} \mathrm{NMR}\left(500 \mathrm{MHz}, \mathrm{CDCl}_{3}\right): \delta 8.19(\mathrm{~d}, J=8.5 \mathrm{~Hz}, 2 \mathrm{H}), 8.03(\mathrm{~d}, J$ $=8.5 \mathrm{~Hz}, 1 \mathrm{H}), 7.98(\mathrm{~d}, J=8.4 \mathrm{~Hz}, 1 \mathrm{H}), 7.92(\mathrm{~d}, J=4.6 \mathrm{~Hz}, 1 \mathrm{H}), 6.96-6.78(\mathrm{~m}$, $1 \mathrm{H}), 6.36(\mathrm{dd}, J=16.6,5.7 \mathrm{~Hz}, 1 \mathrm{H}), 5.91-5.59(\mathrm{~m}, 3 \mathrm{H}), 5.58-5.46(\mathrm{~m}, 2 \mathrm{H})$, 4.68-4.49 (m, 4H), 4.44-4.34 (m, 1H), 4.34-4.25 (m, 0.5H), 4.25-4.16 (m, $0.5 \mathrm{H}), 4.14-3.97(\mathrm{~m}, 2 \mathrm{H}), 3.91-3.78(\mathrm{~m}, 2 \mathrm{H}), 3.68(\mathrm{t}, J=4.8 \mathrm{~Hz}, 1 \mathrm{H}), 3.62-3.38(\mathrm{~m}, 9 \mathrm{H}), 1.58(\mathrm{~d}$, $J=7.2 \mathrm{~Hz}, 1.5 \mathrm{H}), 1.51(\mathrm{~d}, J=7.3 \mathrm{~Hz}, 1.5 \mathrm{H}), 1.46(\mathrm{~d}, J=6.9 \mathrm{~Hz}, 1.5 \mathrm{H}), 1.39(\mathrm{~d}, J=7.0 \mathrm{~Hz}, 1.5 \mathrm{H})$; ${ }^{13} \mathrm{C} \mathrm{NMR}\left(125 \mathrm{MHz}, \mathrm{CDCl}_{3}\right): \delta 166.1,166.0,165.3,164.7,164.5,143.6,143.3,142.5,142.3,134.8$, $134.7,132.6,132.5,132.1,130.8,130.7,129.5,128.5,128.1,128.1,127.9,127.1,125.5,125.4$, 70.7, 70.6, 70.6, 70.5, 70.5, 70.3, 69.4, 69.4, 68.7, 68.5, 65.4, 65.0, 60.3, 60.0, 59.9, 59.3, 59.1, 58.2, $50.5,50.5,47.5,47.2,14.3,12.1,10.5,8.7 ; \mathrm{HRMS}(\mathrm{m} / \mathrm{z})[\mathrm{M}+\mathrm{H}]^{+}$calc'd for $\mathrm{C}_{29} \mathrm{H}_{39} \mathrm{~N}_{4} \mathrm{O}_{12} \mathrm{~S}_{2}$, 699.2000, found 699.2050.

Scheme S4. General procedure for synthesis of allylsulfone-containing macrocyclic monomers.
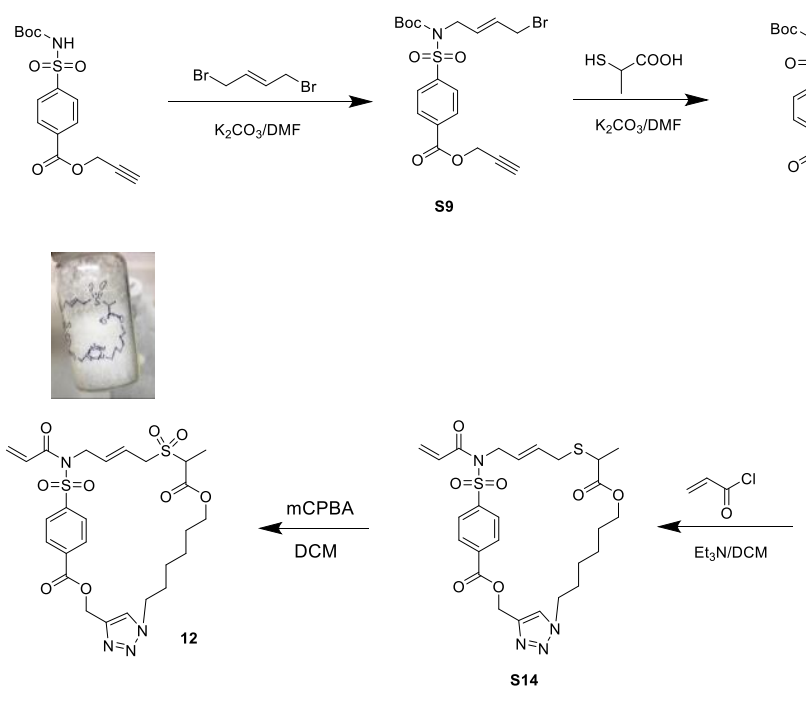
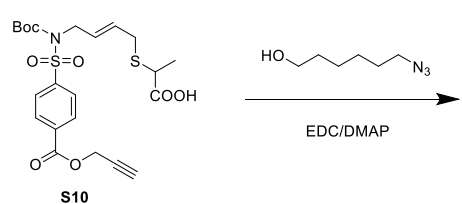

s10
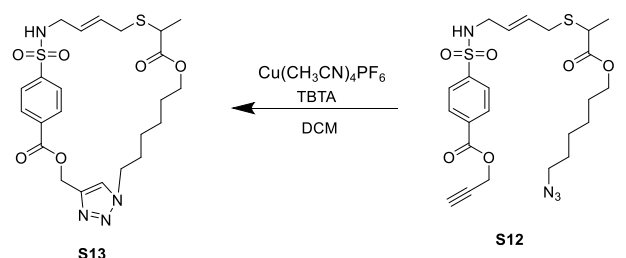

S12

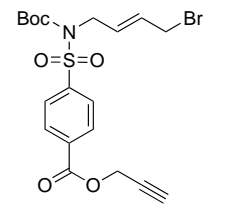

S9: The reaction mixture of prop-2-yn-1-yl 4-(N-(tert-butoxycarbonyl)sulfamoyl) benzoate $(5.90 \mathrm{~g}, 17.4 \mathrm{~mol}),(E)$-1,4-dibromobut-2-ene $(7.44 \mathrm{~g}, 34.8 \mathrm{mmol})$ and $\mathrm{K}_{2} \mathrm{CO}_{3}(4.81 \mathrm{~g}, 34.8 \mathrm{~mol})$ in $30 \mathrm{~mL}$ DMF was stirred at room temperature for $12 \mathrm{~h}$. The reaction was quenched with $100 \mathrm{~mL}$ water and extracted with EtOAc $(3 \times 30$ $\mathrm{mL}$ ). The organic phase was washed with brine, dried over $\mathrm{Na}_{2} \mathrm{SO}_{4}$, filtered and concentrated under vacuum. The residue was purified by column chromatography to afford a colorless oil S9 (5.34 g, 
$65 \%$ yield). ${ }^{1} \mathrm{H}$ NMR (500 MHz, $\left.\mathrm{CDCl}_{3}\right): \delta 8.20(\mathrm{~d}, J=8.5 \mathrm{~Hz}, 2 \mathrm{H}), 8.01(\mathrm{~d}, J=8.5 \mathrm{~Hz}, 2 \mathrm{H}), 6.02$ $(\mathrm{dd}, J=15.1,7.5 \mathrm{~Hz}, 1 \mathrm{H}), 5.93-5.81(\mathrm{~m}, 1 \mathrm{H}), 4.96(\mathrm{~d}, J=2.3 \mathrm{~Hz}, 2 \mathrm{H}), 4.47(\mathrm{~d}, J=6.1 \mathrm{~Hz}, 2 \mathrm{H})$, 3.97 (d, $J=7.5 \mathrm{~Hz}, 2 \mathrm{H}), 2.56$ (s, 1H), 1.35 (s, 9H); ${ }^{13} \mathrm{C}$ NMR (125 MHz, $\left.\mathrm{CDCl}_{3}\right): \delta 164.4,150.4$, 144.2, 133.8, 130.8, 130.2, 129.7, 128.4, 85.3, 77.2, 75.7, 53.3, 47.4, 31.5, 28.0; HRMS (m/z) $[\mathrm{M}+\mathrm{H}]^{+}$calc'd for $\mathrm{C}_{19} \mathrm{H}_{23} \mathrm{NO}_{6} \mathrm{SBr}, 472.0424$, found 472.0433 .

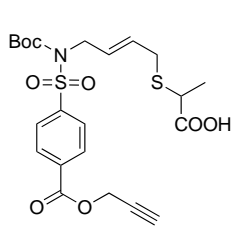

S10: To a well-stirred solution of $\mathbf{S 9}(5.33 \mathrm{~g}, 11.3 \mathrm{mmol})$ and $\mathrm{K}_{2} \mathrm{CO}_{3}(3.12 \mathrm{~g}, 22.6$ $\mathrm{mol})$ in $20 \mathrm{~mL}$ DMF, 2-mercaptopropionic acid $(1.20 \mathrm{~g}, 11.3 \mathrm{mmol})$ was added. The reaction was stirred at room temperature for $12 \mathrm{~h}$. The reaction was acidified with $1 \mathrm{M}$ aq. $\mathrm{HCl}$ and extracted with EtOAc $(3 \times 30 \mathrm{~mL})$. The organic phase was washed with brine, dried over $\mathrm{Na}_{2} \mathrm{SO}_{4}$, filtered and concentrated under vacuum. The residue was purified by column chromatography to afford a white solid $\mathbf{S 1 0}$ ( $4.95 \mathrm{~g}, 88 \%$ total yield). ${ }^{1} \mathrm{H}$ NMR (600 MHz, $\left.\mathrm{CDCl}_{3}\right): \delta 8.18(\mathrm{~d}, J=8.5 \mathrm{~Hz}, 2 \mathrm{H}), 7.98(\mathrm{~d}, J=8.5 \mathrm{~Hz}, 2 \mathrm{H}), 5.77$ (q, $J$ $=6.2,5.2 \mathrm{~Hz}, 2 \mathrm{H}), 4.95(\mathrm{~d}, J=2.4 \mathrm{~Hz}, 2 \mathrm{H}), 4.44(\mathrm{~d}, J=5.0 \mathrm{~Hz}, 2 \mathrm{H}), 3.39(\mathrm{dq}, J=14.4,6.9 \mathrm{~Hz}$, 2H), $3.24(\mathrm{dd}, J=13.6,4.8 \mathrm{~Hz}, 1 \mathrm{H}), 2.55(\mathrm{t}, J=2.4 \mathrm{~Hz}, 1 \mathrm{H}), 1.42(\mathrm{~d}, J=7.2 \mathrm{~Hz}, 3 \mathrm{H}), 1.32(\mathrm{~s}, 9 \mathrm{H})$; ${ }^{13} \mathrm{C}$ NMR $\left(150 \mathrm{MHz}, \mathrm{CDCl}_{3}\right): \delta 179.0,164.4,150.4,144.4,133.6,130.2,129.8,128.5,128.2,85.2$, 77.2, 75.8, 53.3, 47.9, 39.5, 33.4, 28.0, 16.7; HRMS (m/z) $\left[\mathrm{M}+\mathrm{NH}_{4}\right]^{+}$calc'd for $\mathrm{C}_{22} \mathrm{H}_{31} \mathrm{~N}_{2} \mathrm{O}_{8} \mathrm{~S}_{2}$, 515.1516, found 515.1517.

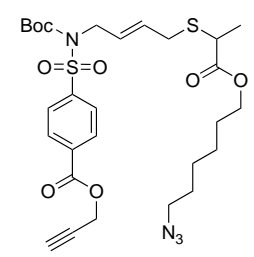

S11: In a $100 \mathrm{~mL}$ flask, a mixture of $\mathbf{S 1 0}(4.80 \mathrm{~g}, 9.65 \mathrm{mmol})$, EDC hydrochloride $(2.40 \mathrm{~g}, 12.5 \mathrm{mmol})$ and 6-azidohexan-1-ol $(1.80 \mathrm{~g}, 12.5 \mathrm{mmol})$ in $30 \mathrm{~mL}$ of DCM was stirred in ice bath. The 4-dimethylaminopyridine $(1.77 \mathrm{~g}, 14.5 \mathrm{mmol})$ was slowly added and the mixture was stirred at room temperature for $12 \mathrm{~h}$. The reaction was quenched with $1 \mathrm{M}$ aq. $\mathrm{HCl}$ and extracted with $\mathrm{DCM}(3 \times 30 \mathrm{~mL})$.

The combined organic layers were washed with brine $(30 \mathrm{~mL})$ and concentrated in vacuo. The crude material was purified by flash column chromatography to give a colorless oil S11 (3.80 g, 63\% yield). $\delta 8.20(\mathrm{~d}, J=8.7 \mathrm{~Hz}, 2 \mathrm{H}), 7.99(\mathrm{~d}, J=8.7 \mathrm{~Hz}, 2 \mathrm{H}), 5.91-5.67(\mathrm{~m}, 2 \mathrm{H}), 4.96(\mathrm{~d}, J=2.5 \mathrm{~Hz}$, $2 \mathrm{H}), 4.44(\mathrm{~d}, J=5.6 \mathrm{~Hz}, 2 \mathrm{H}), 4.24-4.05(\mathrm{~m}, 2 \mathrm{H}), 3.44-3.17(\mathrm{~m}, 5 \mathrm{H}), 2.55(\mathrm{t}, J=2.5 \mathrm{~Hz}, 1 \mathrm{H}), 1.72$ $1.56(\mathrm{~m}, 4 \mathrm{H}), 1.44-1.38(\mathrm{~m}, 7 \mathrm{H}), 1.34(\mathrm{~s}, 9 \mathrm{H}) . ;{ }^{13} \mathrm{C} \mathrm{NMR}\left(125 \mathrm{MHz}, \mathrm{CDCl}_{3}\right): \delta$ 173.1, 164.4, 150.4, 144.5, 133.6, 130.3, 130.2, 128.2, 128.2, 85.1, 77.2, 75.7, 65.1, 53.3, 51.4, 47.9, 40.1, 33.2, 28.8, 28.6, 28.0, 26.5, 25.6, 17.1; HRMS (m/z) $\left[\mathrm{M}+\mathrm{NH}_{4}\right]^{+}$calc'd for $\mathrm{C}_{28} \mathrm{H}_{42} \mathrm{~N}_{5} \mathrm{O}_{8} \mathrm{~S}_{2}, 640.2469$, found 640.2467

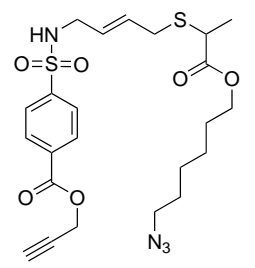

S12: In a $100 \mathrm{~mL}$ flask, S11 (4.62 g, $7.42 \mathrm{mmol})$ was dissolved in $20 \mathrm{~mL}$ DCM, the mixture was cooled at $0{ }^{\circ} \mathrm{C}$, then TFA $(2.9 \mathrm{~mL}, 37.1 \mathrm{mmol})$ was added dropwise and the reaction was stirred for 36 hours at room temperature. The reaction was quenched with saturate sodium bicarbonate solution and extracted with DCM (3 x $30 \mathrm{~mL})$. The organic phase was washed with brine and concentrated under vacuum. The crude material was purified by flash column chromatography to give a colorless oil $\mathbf{S 1 2}(2.75 \mathrm{~g}, 71 \%)$. ${ }^{1} \mathrm{H}$ NMR $\left(600 \mathrm{MHz}, \mathrm{CDCl}_{3}\right): \delta 8.22(\mathrm{~d}, J=8.4 \mathrm{~Hz}, 2 \mathrm{H}), 7.96$ $(\mathrm{d}, J=8.4 \mathrm{~Hz}, 2 \mathrm{H}), 5.64-5.46(\mathrm{~m}, 2 \mathrm{H}), 5.00-4.93(\mathrm{~m}, 2 \mathrm{H}), 4.69(\mathrm{~s}, 1 \mathrm{H}), 4.11(\mathrm{td}, J=6.6,3.0 \mathrm{~Hz}$, $3 \mathrm{H}), 3.61(\mathrm{p}, J=8.2,7.4 \mathrm{~Hz}, 2 \mathrm{H}), 3.25(\mathrm{ddd}, J=30.2,13.2,7.2 \mathrm{~Hz}, 4 \mathrm{H}), 3.11(\mathrm{dd}, J=13.8,6.4 \mathrm{~Hz}$, $1 \mathrm{H}), 2.55(\mathrm{t}, J=2.4 \mathrm{~Hz}, 1 \mathrm{H}), 1.72-1.58(\mathrm{~m}, 4 \mathrm{H}), 1.41(\mathrm{~d}, J=7.2 \mathrm{~Hz}, 7 \mathrm{H}) ;{ }^{13} \mathrm{C}$ NMR $(150 \mathrm{MHz}$, $\left.\mathrm{CDCl}_{3}\right): \delta 173.3,164.5,144.6,133.2,130.7,129.9,127.9,127.3,77.3,75.7,65.2,53.2,51.4,44.9$, 

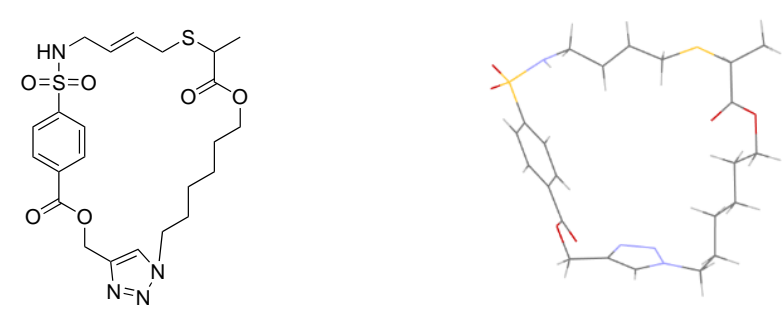

S13: Compound S13 was prepared following a procedure slightly modified from literature. ${ }^{5}$ In a $500 \mathrm{~mL}$ round-bottom pressure flask, $\mathbf{S 1 2}(2.60 \mathrm{~g})$ was dissolved in dry DCM $(300 \mathrm{~mL})$, the solution was degassed by nitrogen for $15 \mathrm{~min}$. To this solution was added TBTA (103.8 mg) and tetrakis(acetonitrile)copper(I) hexafluorophosphate $(92.7 \mathrm{mg}$ ). The reaction mixture was flushed with nitrogen and stirred at $55{ }^{\circ} \mathrm{C}$ for $36 \mathrm{~h}$. The reaction mixture was cooled to room temperature and quenched with methanol, then concentrated under vacuum. The crude material was purified by flash column chromatography to give a white solid S13 (2.05g, 79\% yield). ${ }^{1} \mathrm{H}$ NMR (600 MHz, $\left.\mathrm{CDCl}_{3}\right) \delta 8.13(\mathrm{~d}, J=8.5 \mathrm{~Hz}, 2 \mathrm{H}), 7.92(\mathrm{~d}, J=8.6 \mathrm{~Hz}, 2 \mathrm{H}), 7.71(\mathrm{~s}, 1 \mathrm{H}), 5.58(\mathrm{br}, 1 \mathrm{H}), 5.52(\mathrm{~s}, 2 \mathrm{H})$, $5.40(\mathrm{dt}, J=14.8,7.3 \mathrm{~Hz}, 1 \mathrm{H}), 5.21-5.13(\mathrm{~m}, 1 \mathrm{H}), 4.37$ (tt, $J=9.8,4.8 \mathrm{~Hz}, 2 \mathrm{H}), 3.97-3.86(\mathrm{~m}, 2 \mathrm{H})$, $3.68(\mathrm{q}, J=5.5 \mathrm{~Hz}, 2 \mathrm{H}), 3.07(\mathrm{q}, J=7.2 \mathrm{~Hz}, 1 \mathrm{H}), 2.98-2.85(\mathrm{~m}, 2 \mathrm{H}), 1.86(\mathrm{p}, J=6.9 \mathrm{~Hz}, 2 \mathrm{H}), 1.45$ $(\mathrm{dq}, J=13.9,7.0 \mathrm{~Hz}, 2 \mathrm{H}), 1.29-1.09(\mathrm{~m}, 7 \mathrm{H}) ;{ }^{13} \mathrm{C} \mathrm{NMR}\left(150 \mathrm{MHz}, \mathrm{CDCl}_{3}\right) \delta 172.8,165.0,145.2$, 142.6, 133.4, 130.5, 129.9, 127.6, 127.3, 124.5, 64.8, 58.4, 50.5, 45.1, 40.1, 32.9, 29.8, 28.2, 25.9, 25.2, 16.9; HRMS (m/z) $[\mathrm{M}+\mathrm{H}]^{+}$calc'd for $\mathrm{C}_{23} \mathrm{H}_{31} \mathrm{~N}_{4} \mathrm{O}_{6} \mathrm{~S}_{2}, 523.1680$, found 523.1667. The colorless crystalloid of $\mathbf{S 1 3}$ were obtained via slow solvent evaporation from a DCM solution of the compound at room temperature (see Table S1 for the crystallographic data).

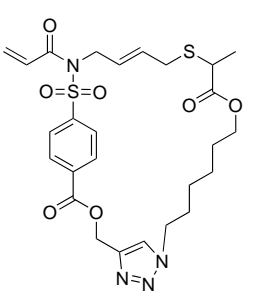

S14: In a $100 \mathrm{~mL}$ flask, a mixture of $\mathbf{S 1 3}(1.70 \mathrm{~g}, 3.25 \mathrm{mmol})$ and triethylamine $(2.3 \mathrm{~mL}, 16.3 \mathrm{mmol})$ in $20 \mathrm{~mL}$ of DCM was stirred in ice bath. The acryloyl chloride $(1.3 \mathrm{~mL}, 16.3 \mathrm{mmol})$ was slowly added and the mixture was stirred at room temperature for $15 \mathrm{~h}$. The reaction was quenched with saturate sodium bicarbonate solution and extracted with DCM $(3 \times 30 \mathrm{~mL})$. The combined organic layers were washed with brine $(30 \mathrm{~mL})$ and concentrated in vacuo. The crude material was purified by flash column chromatography to give a yellow solid $\mathbf{S 1 4}(1.21 \mathrm{~g}, 65 \%$ yield). ${ }^{1} \mathrm{H}$ NMR (600 MHz, $\left.\mathrm{CDCl}_{3}\right): \delta 8.13(\mathrm{~d}, J=8.7 \mathrm{~Hz}, 2 \mathrm{H}), 8.01(\mathrm{~d}, J=8.7 \mathrm{~Hz}, 2 \mathrm{H}), 7.68(\mathrm{~s}$, $1 \mathrm{H}), 6.75(\mathrm{dd}, J=16.6,10.4 \mathrm{~Hz}, 1 \mathrm{H}), 6.35(\mathrm{dd}, J=16.7,1.5 \mathrm{~Hz}, 1 \mathrm{H}), 5.77(\mathrm{dd}, J=10.4,1.5 \mathrm{~Hz}$, $1 \mathrm{H}), 5.64(\mathrm{dt}, J=14.6,7.2 \mathrm{~Hz}, 1 \mathrm{H}), 5.54-5.43(\mathrm{~m}, 3 \mathrm{H}), 4.62-4.52(\mathrm{~m}, 2 \mathrm{H}), 4.45-4.33(\mathrm{~m}, 2 \mathrm{H})$, 4.03-3.89 (m, 2H), 3.24-3.03 (m, 3H), 1.88 (dt, $J=14.1,6.5 \mathrm{~Hz}, 2 \mathrm{H}), 1.52$ (dq, $J=14.3,7.1 \mathrm{~Hz}$, 2H), 1.29 (dd, $J=29.1,7.3 \mathrm{~Hz}, 5 \mathrm{H}), 1.17(\mathrm{dq}, J=15.1,7.3 \mathrm{~Hz}, 2 \mathrm{H}) ;{ }^{13} \mathrm{C} \mathrm{NMR}\left(150 \mathrm{MHz}, \mathrm{CDCl}_{3}\right)$ : $\delta$ 172.5, 165.3 164.7, 143.6, 142.3, 134.5, 132.5, 130.7, 130.4, 128.5, 127.9, 127.3, 124.3, 64.7, $58.9,50.5,47.4,40.2,32.9,29.8,28.1,25.8,25.0,16.7$; HRMS $(\mathrm{m} / \mathrm{z})[\mathrm{M}+\mathrm{H}]^{+}$calc'd for $\mathrm{C}_{26} \mathrm{H}_{33} \mathrm{~N}_{4} \mathrm{O}_{7} \mathrm{~S}_{2}, 577.1785$, found 577.1781. 


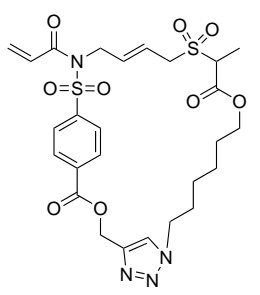

12: the compound $\mathbf{S 1 4}$ (800 $\mathrm{mg}, 1.4 \mathrm{mmol})$ was dissolved in DCM (20 mL), and $77 \%$ mCPBA (933 mg, $4.2 \mathrm{mmol}$ ) was added. After stirring for $1 \mathrm{~h}$ at room temperature, the reaction was quenched with saturate sodium bicarbonate solution and extracted with DCM $(3 \times 30 \mathrm{~mL})$. The combined organic layers were washed with brine $(30 \mathrm{~mL})$ and concentrated in vacuo. The residue was purified by flash column chromatography to give the white solid $12(610 \mathrm{mg}, 72 \%$ yield). ${ }^{1} \mathrm{H}$ NMR (600 MHz, $\left.\mathrm{CDCl}_{3}\right): \delta 8.16(\mathrm{~d}, J=8.7 \mathrm{~Hz}, 2 \mathrm{H}), 8.02(\mathrm{~d}, J=8.7 \mathrm{~Hz}, 2 \mathrm{H}), 7.69(\mathrm{~s}$, $1 \mathrm{H}), 6.78(\mathrm{dd}, J=16.6,10.4 \mathrm{~Hz}, 1 \mathrm{H}), 6.36(\mathrm{dd}, J=16.6,1.4 \mathrm{~Hz}, 1 \mathrm{H}), 5.84(\mathrm{dt}, J=15.5,6.0 \mathrm{~Hz}$, $1 \mathrm{H}), 5.79(\mathrm{dd}, J=10.4,1.4 \mathrm{~Hz}, 1 \mathrm{H}), 5.70(\mathrm{dt}, J=15.4,7.4 \mathrm{~Hz}, 1 \mathrm{H}), 5.48(\mathrm{~s}, 2 \mathrm{H}), 4.66(\mathrm{~d}, J=6.0$ $\mathrm{Hz}, 2 \mathrm{H}$ ), 4.39 (hept, $J=6.9,6.2 \mathrm{~Hz}, 2 \mathrm{H}$ ), 4.07 (ddt, $J=35.7,10.8,7.1 \mathrm{~Hz}, 2 \mathrm{H}$ ), 3.85 (p, $J=7.3 \mathrm{~Hz}$, 2H), $3.76(\mathrm{dd}, J=13.7,6.7 \mathrm{~Hz}, 1 \mathrm{H}), 1.90(\mathrm{dt}, J=14.1,6.3 \mathrm{~Hz}, 2 \mathrm{H}), 1.63-1.50(\mathrm{~m}, 5 \mathrm{H}), 1.38-1.15$ (m, 4H); ${ }^{13} \mathrm{C}$ NMR $\left(150 \mathrm{MHz}, \mathrm{CDCl}_{3}\right): \delta 166.5,165.3,164.8,143.3,142.4,135.0,134.7,132.8$, 130.6, 128.6, 127.8, 124.3, 120.3, 66.3, 62.2, 59.0, 54.4, 50.4, 47.1, 29.7, 27.9, 25.7, 24.8, 10.4; HRMS (m/z) $[\mathrm{M}+\mathrm{H}]^{+}$calc'd for $\mathrm{C}_{26} \mathrm{H}_{33} \mathrm{~N}_{4} \mathrm{O}_{9} \mathrm{~S}_{2}, 609.1684$, found 609.1690 . 
Table S1. Crystal data and structure refinement for macrocyclic compound S13.

Identification code

Empirical formula

Formula weight

Temperature

Wavelength

Crystal system

Space group

Unit cell dimensions

Volume

Z

Density (calculated)

Absorption coefficient

$\mathrm{F}(000)$

Crystal size

Theta range for data collection

Index ranges

Reflections collected

Independent reflections

Completeness to theta $=66.714^{\circ}$

Absorption correction

Max. and min. transmission

Refinement method

Data / restraints / parameters

Goodness-of-fit on $\mathrm{F}^{2}$

Final $\mathrm{R}$ indices [I $>2 \operatorname{sigma}(\mathrm{I})]$

$\mathrm{R}$ indices (all data)

Extinction coefficient

Largest diff. peak and hole
C23H30N4O6S2

C23 H30 N4 O6 S2

522.63

123(2) K

$1.54178 \AA$

Monoclinic

$\mathrm{P} 21 / \mathrm{c}$

$\mathrm{a}=12.3464(6) \AA$

$\alpha=90^{\circ}$.

$\mathrm{b}=23.8926(11) \AA$

$\beta=109.610(3)^{\circ}$.

$\mathrm{c}=10.3661(5) \AA$

$\gamma=90^{\circ}$

$2880.5(2) \AA^{3}$

4

$1.205 \mathrm{Mg} / \mathrm{m}^{3}$

$2.020 \mathrm{~mm}^{-1}$

1104

$0.560 \times 0.160 \times 0.100 \mathrm{~mm}^{3}$

3.801 to $66.714^{\circ}$.

$-14<=\mathrm{h}<=14,-28<=\mathrm{k}<=23,-11<=1<=12$

17102

$5075[\mathrm{R}(\mathrm{int})=0.0350]$

$99.5 \%$

Semi-empirical from equivalents

0.7528 and 0.5071

Full-matrix least-squares on $\mathrm{F}^{2}$

5075 / 422 / 483

1.032

$\mathrm{R} 1=0.0565, \mathrm{wR} 2=0.1592$

$\mathrm{R} 1=0.0672, \mathrm{wR} 2=0.1709$

$\mathrm{n} / \mathrm{a}$

0.420 and -0.282 e. $\AA^{-3}$ 
Scheme S5. Ring-closing polymerization of monomer 3.

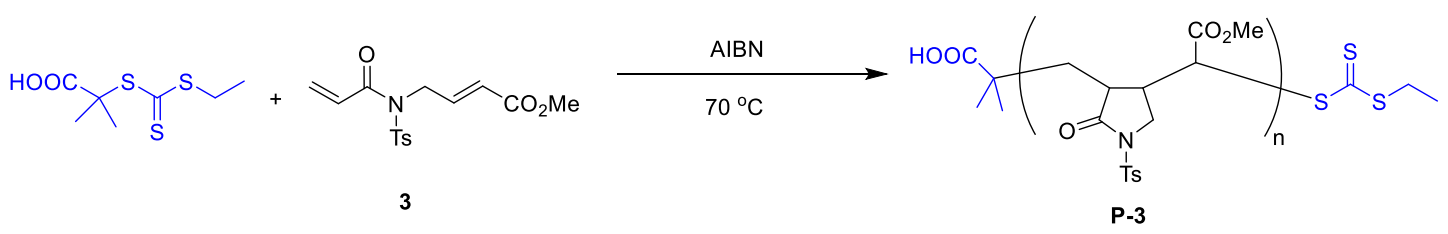

A $10 \mathrm{~mL}$ Schlenk vial equipped with a stir bar was charged with macrocyclic monomer $\mathbf{3}(0.2 \mathrm{mmol}$, $0.2 \mathrm{M})$, followed by the stock solution of $16 \mathrm{mM}$ CTA $(250 \mu \mathrm{L}), 16 \mathrm{mM}$ AIBN $(75.2 \mu \mathrm{L})$ and solvent $(674.8 \mu \mathrm{L})$. The vial was sealed. The solution was deoxygenated via three freeze-pumpthaw cycles, backfilled with nitrogen, and then heated at $70{ }^{\circ} \mathrm{C}$ for a given time. After reaction, the vial was cooled by ice bath and open to air to stop the polymerization. The reaction mixture was diluted with minimum amount of DCM and precipitated in diethyl ether. The obtained solid was redissolved with a minimum amount of DCM for further precipitation, yielding the polymer which was then characterized using SEC, ${ }^{1} \mathrm{H}-\mathrm{NMR}$ and ${ }^{13} \mathrm{C}-\mathrm{NMR}$. ${ }^{1} \mathrm{H}$ NMR $\left(500 \mathrm{MHz}, \mathrm{CDCl}_{3}\right): \delta 7.88(\mathrm{~s}$, 2H), 7.33 (s, 2H), 4.26-0.99 (m, 13H); ${ }^{13} \mathrm{C}$ NMR (125 MHz, $\left.\mathrm{CDCl}_{3}\right): \delta$ 173.3(br), 145.6, 135.0, 130.0, 128.3, 52.5, 48.0(br), 43.8(br), 39.6(br), 28.4(br), 21.8.

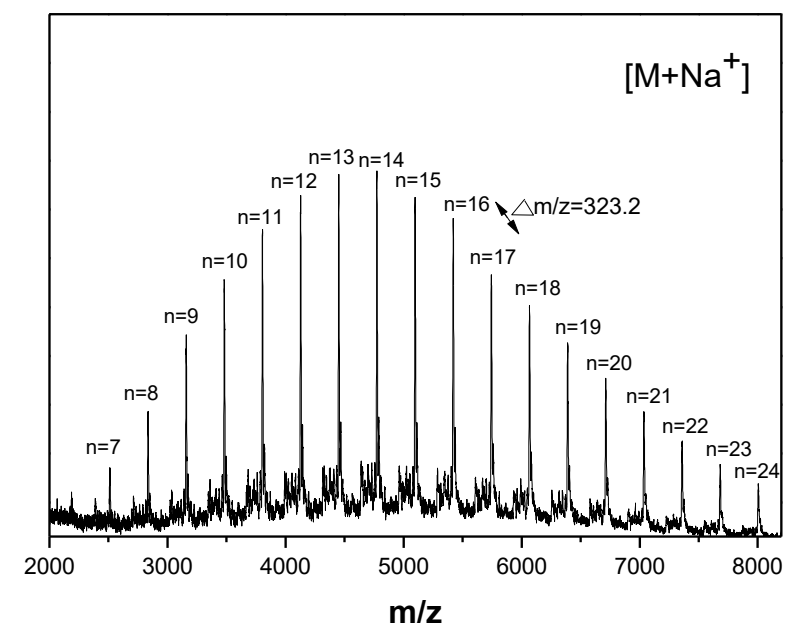

Figure S1. MALDI-TOF analysis of polymer $\mathbf{P - 3}$. 
(a) ${ }^{1} \mathrm{H}$ NMR

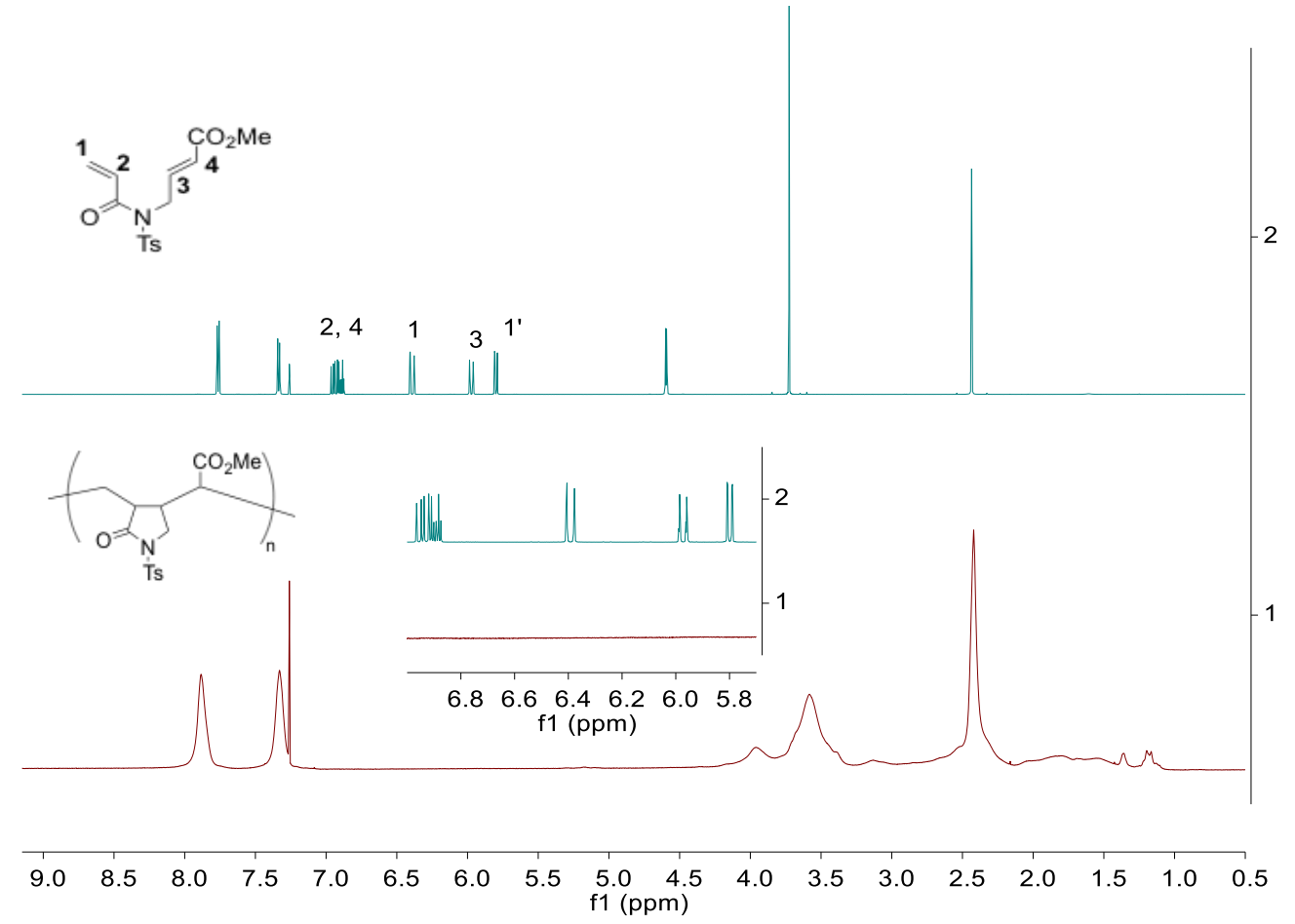

(b) ${ }^{13} \mathrm{C}$ NMR

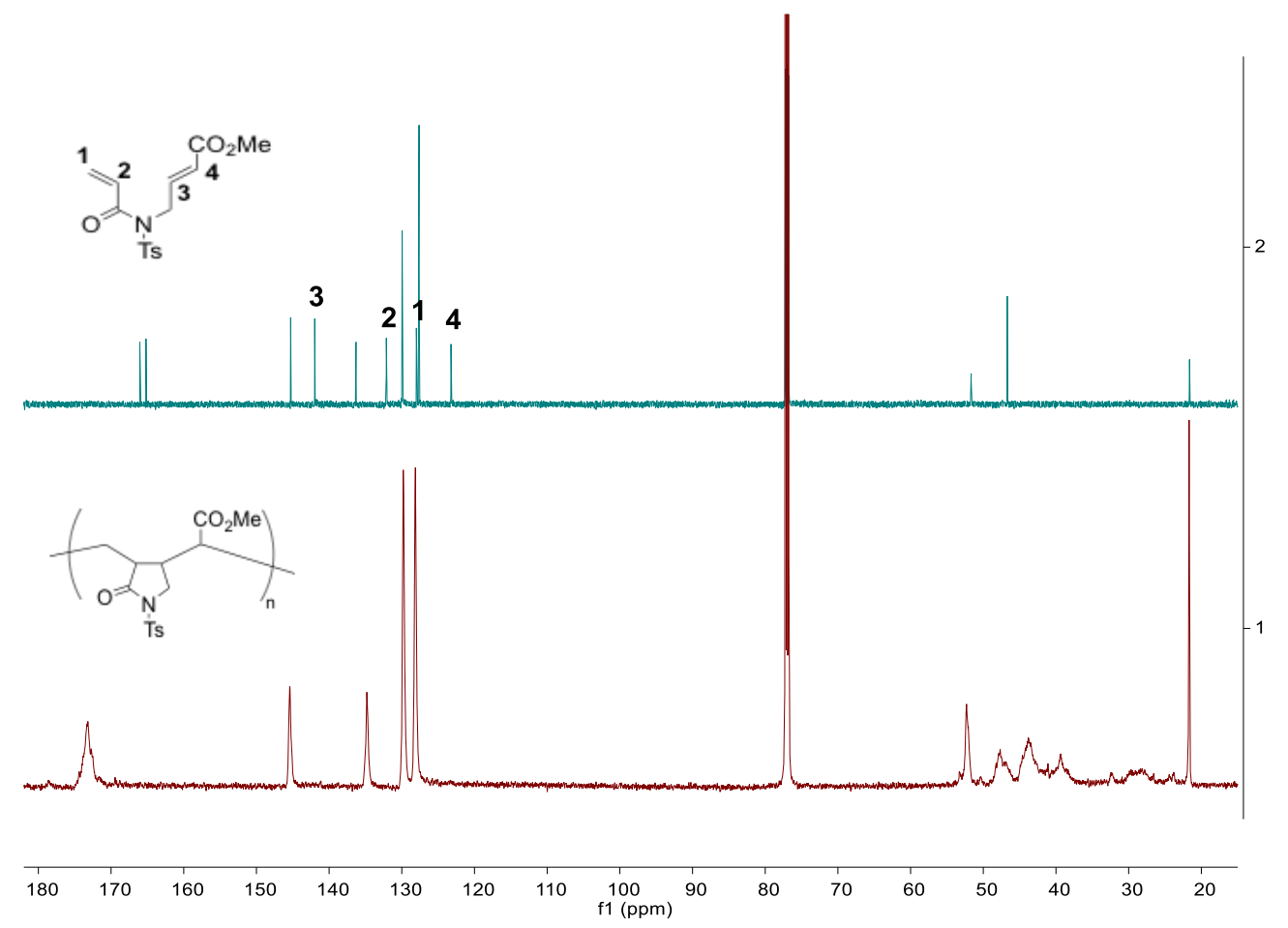

Figure S2. NMR spectral comparison of monomer $\mathbf{3}$ and polymer P-3. The peaks of alkene all disappeared after polymerization, suggesting the high efficiency of the intramolecular cyclization. 
(A)

$$
\overbrace{\substack{T_{\mathrm{N}} \\ \mathrm{Boc}}}^{\mathrm{b}} \overbrace{\mathrm{CO}_{2} \mathrm{Me}}^{\mathrm{c}}
$$

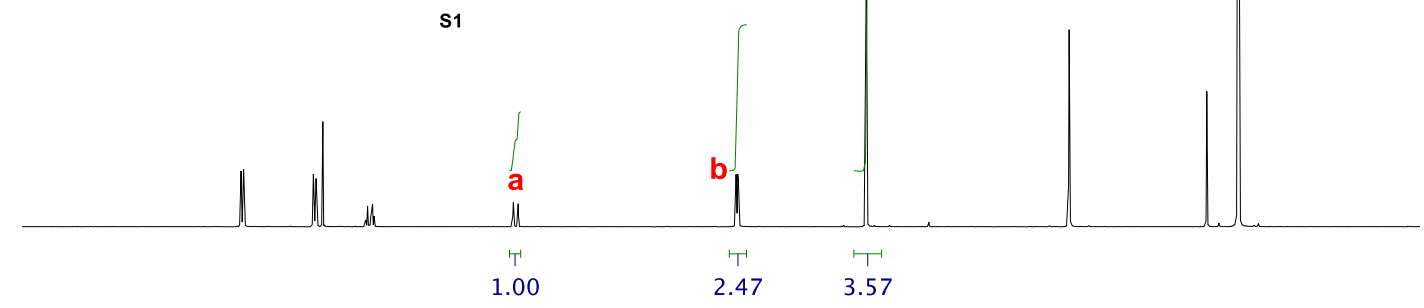

(B)
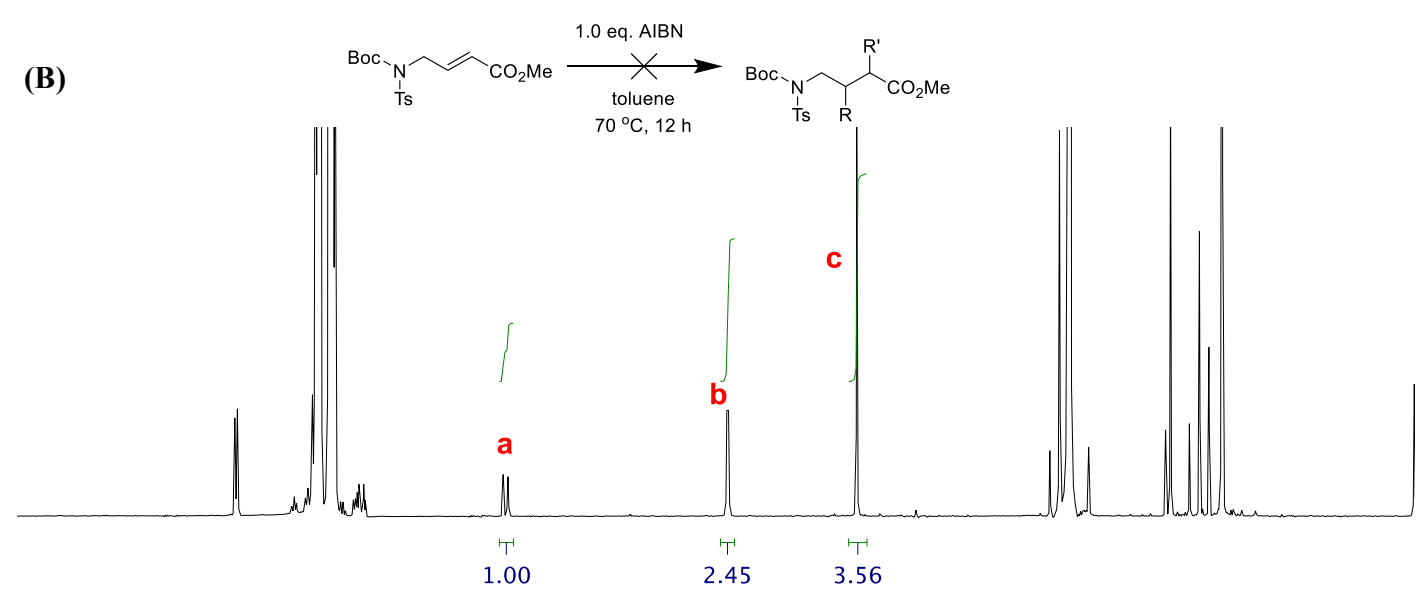

(C)
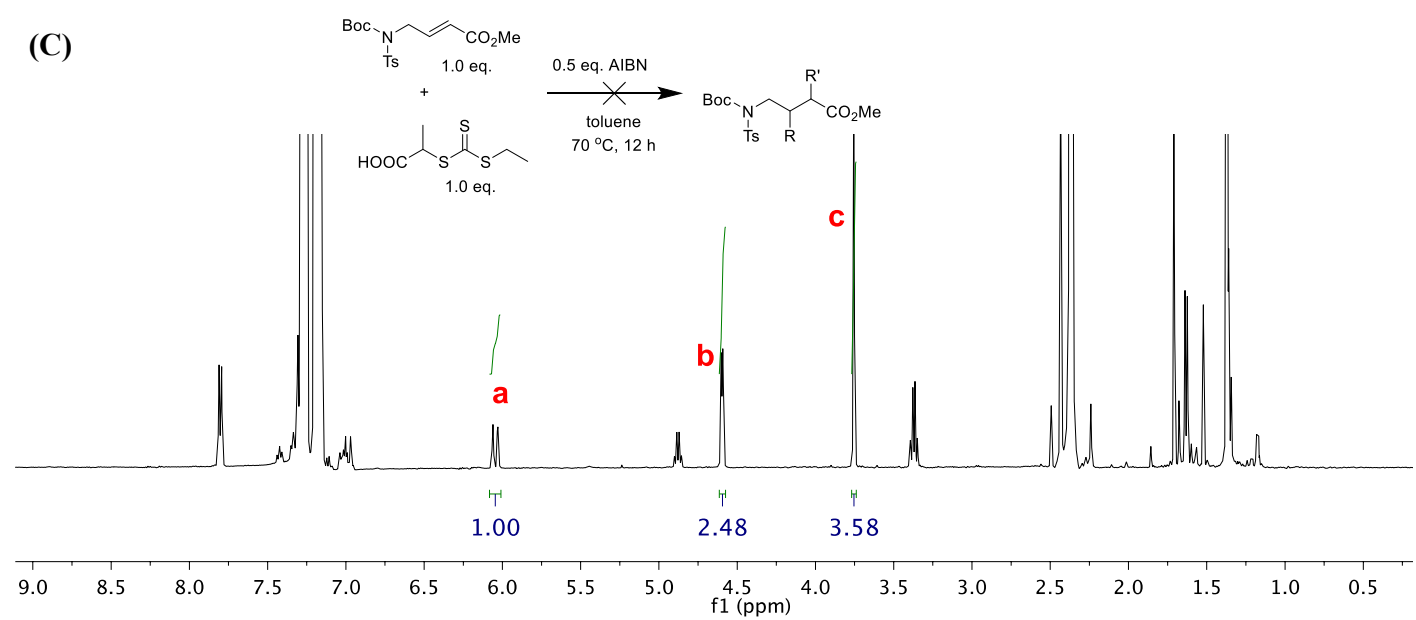

Figure S3. Experimental validation that ring-closing polymerization does not initiate at the internal alkene. No initiation was observed when the acryloyl group is absent from the monomer, indicated by the lack of division of the methyl signal $\mathbf{c}$ of $\mathbf{S 1}$ and the lack of change of the integration ratio of $\mathrm{a}$ and $\mathrm{c}$ in NMR analysis. 
i. Initiation

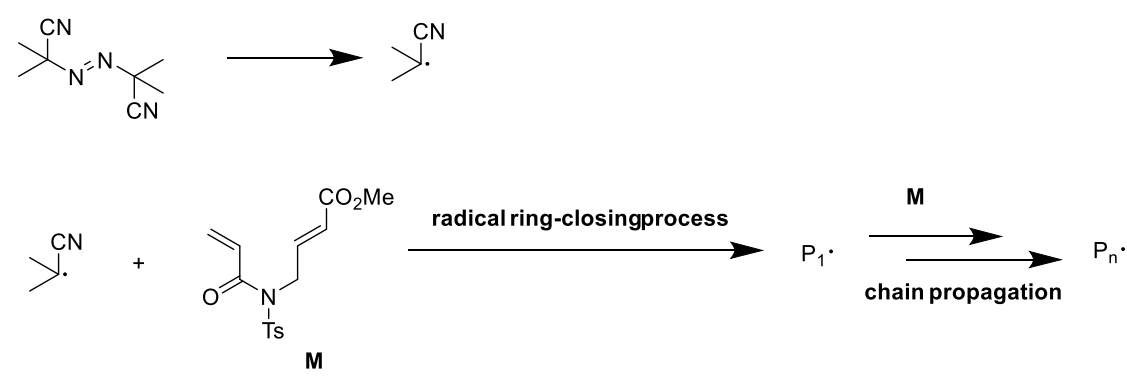

ii. Chain transferto RAFT agent

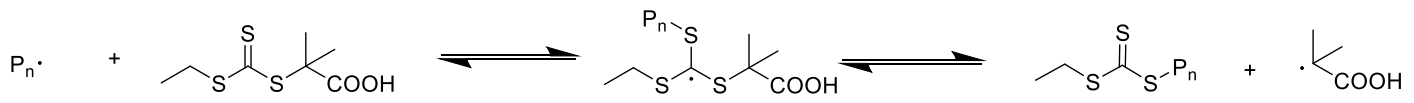

iii. Reinitiation

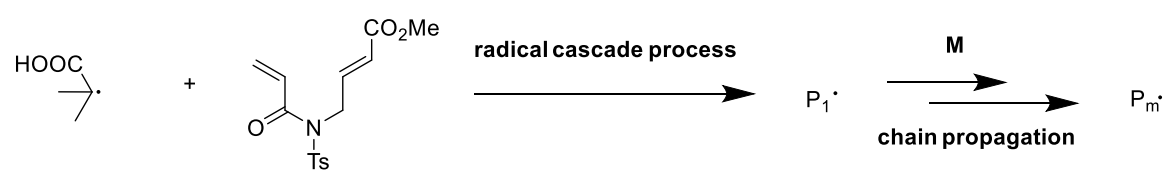

iv. Degenerative chain transferpropagation

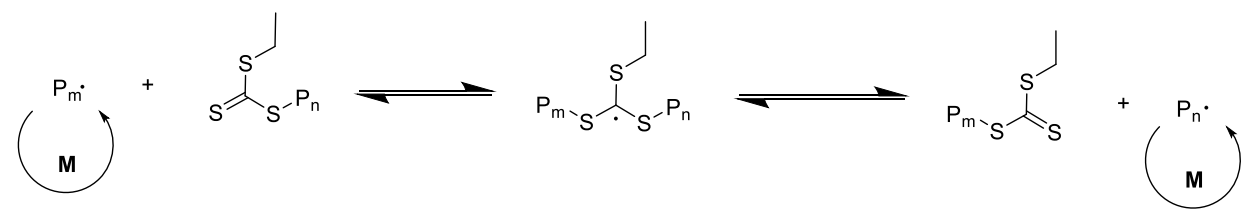

v. Termination

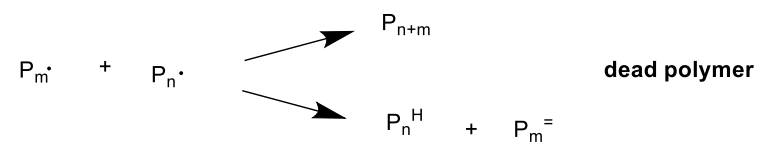

Radical ring-closingprocess

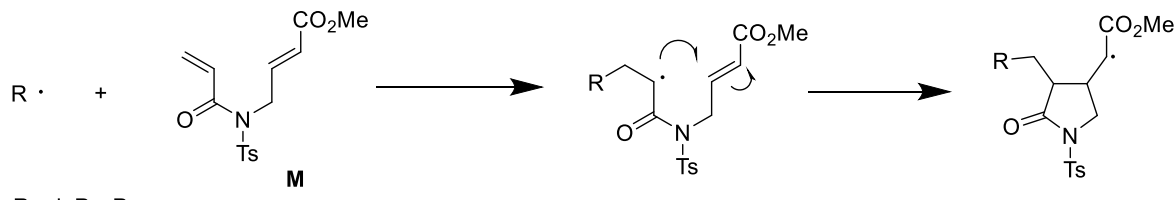

$R=i, P_{n}, P_{m}$

Figure S4. Proposed mechanism for the ring-closing polymerization. 
NMR analysis of the conversion of monomer 3.

Determination of monomer conversion for the polymerizations of monomer $\mathbf{3}$ was made based on the assumption that the integral of the peak at $\delta=7.88 \mathrm{ppm}$ (Peak a, Figure S5) corresponds to the phenyl group of the polymer P-3, and the integral of the peak at $\delta=7.76 \mathrm{ppm}$ (Peak b, Figure S5) corresponds to phenyl group of unreacted monomer. When the integral of Peak a is normalized to 1, the monomer conversion $\alpha$ is calculated based on the following equation:

$$
\alpha=\frac{1}{1+I_{b}} \times 100 \%
$$

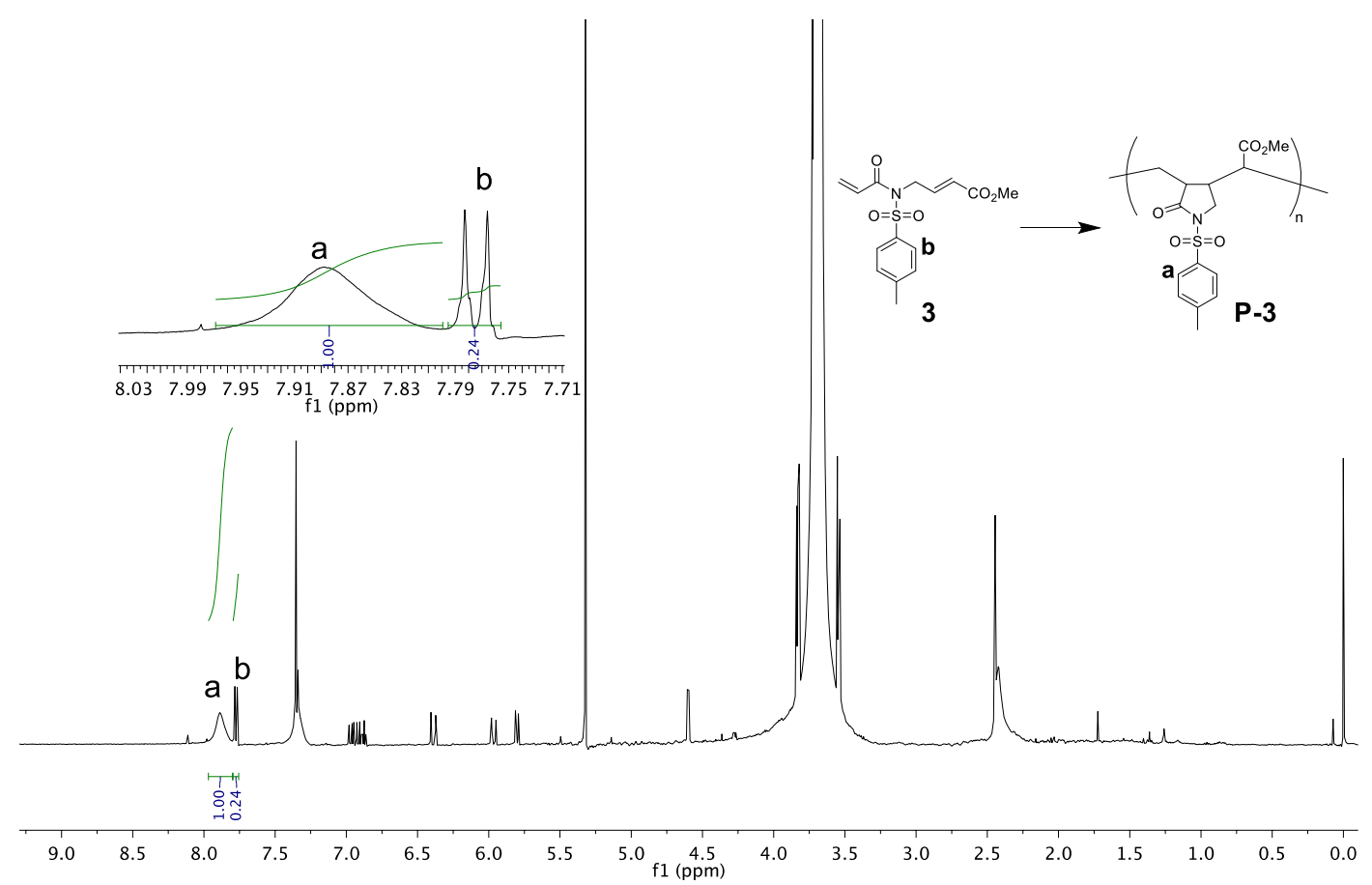

Figure S5. NMR determination of monomer conversion for the polymerization of monomer 3. In this example, Peak a (the phenyl group of the polymer) was normalized to 1 , the conversion is thus calculated as $\alpha=1 /(1+0.24) \times 100 \%=81 \%$. 
Table S2. Ring-closing polymerization of different monomers.<smiles>[R]C(=C)C([X])N([13CH3])C/C=C/C(C)=O</smiles>
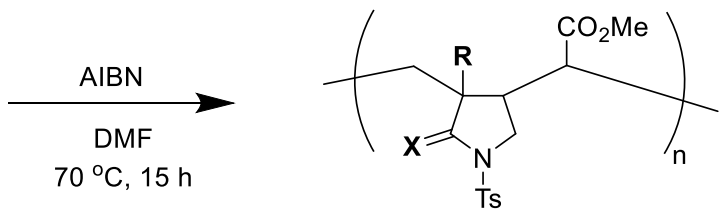

$$
\text { Entry } \text { Monomers }^{a} \text { Conversion }{ }^{b}
$$

${ }^{a}$ Experimental conditions: $\left[\mathrm{M}^{\mathrm{M}}=0.2 \mathrm{M}, 70^{\circ} \mathrm{C}\right.$ under nitrogen for $15 \mathrm{~h}$, unless otherwise noted. ${ }^{b}$ Monomer conversion was determined by ${ }^{1} \mathrm{H}$ NMR spectroscopy. ${ }^{c}$ Molecular weight and polydispersity index $\left(M_{\mathrm{w}} / M_{\mathrm{n}}\right)$ were determined by SEC analysis calibrated to polystyrene standards.

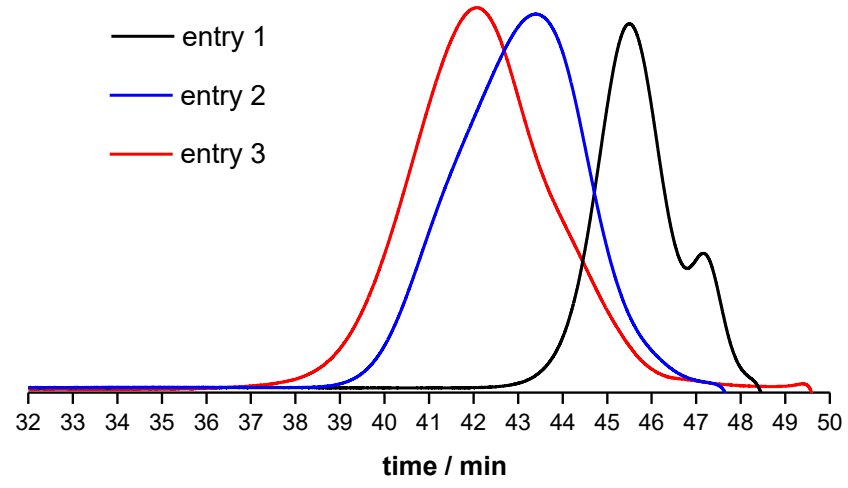

Figure S6. SEC traces for ring-closing polymerization of different monomers. 
Table S3. Effect of different CTAs on the polymerization of monomer 3.

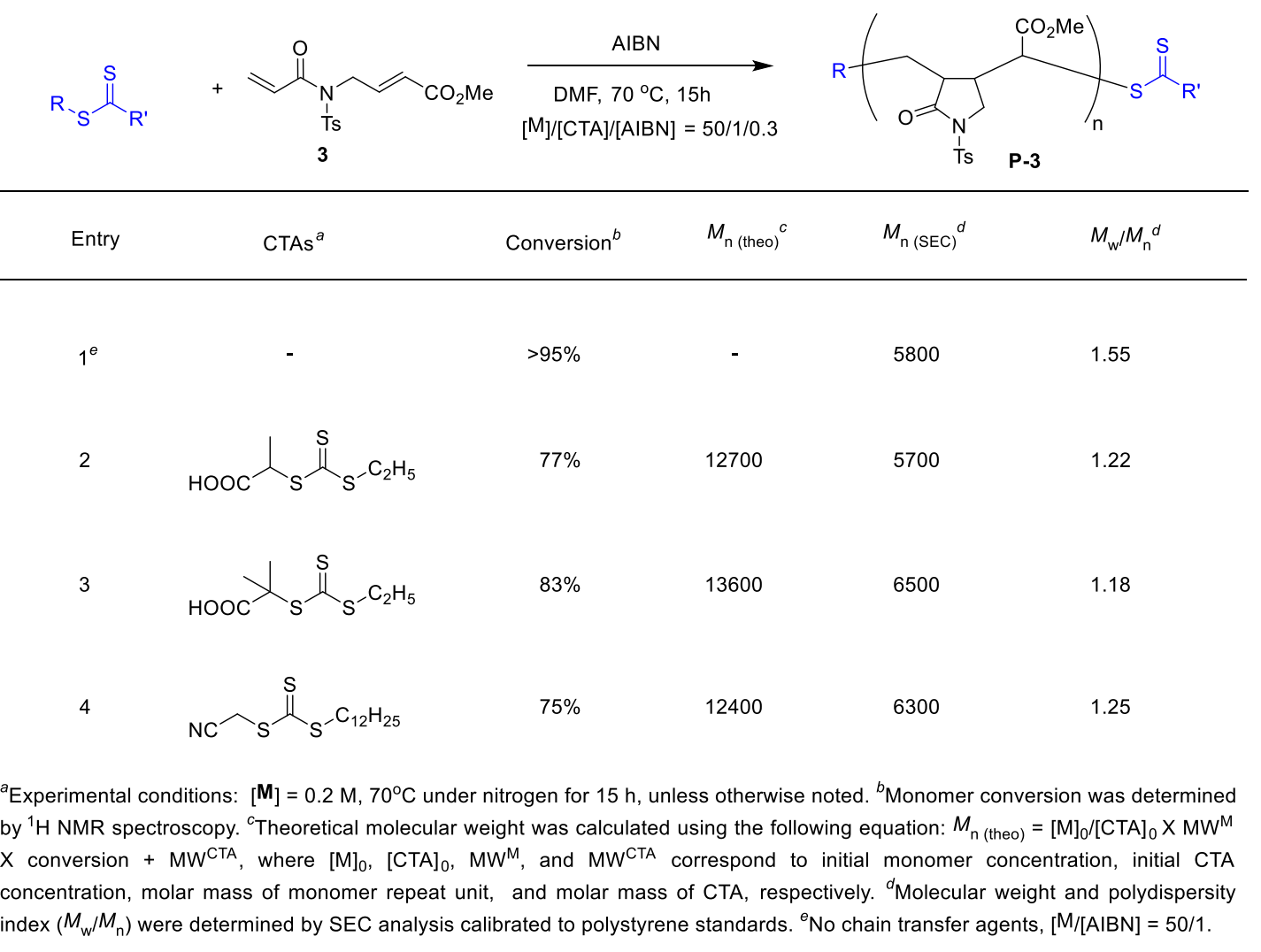

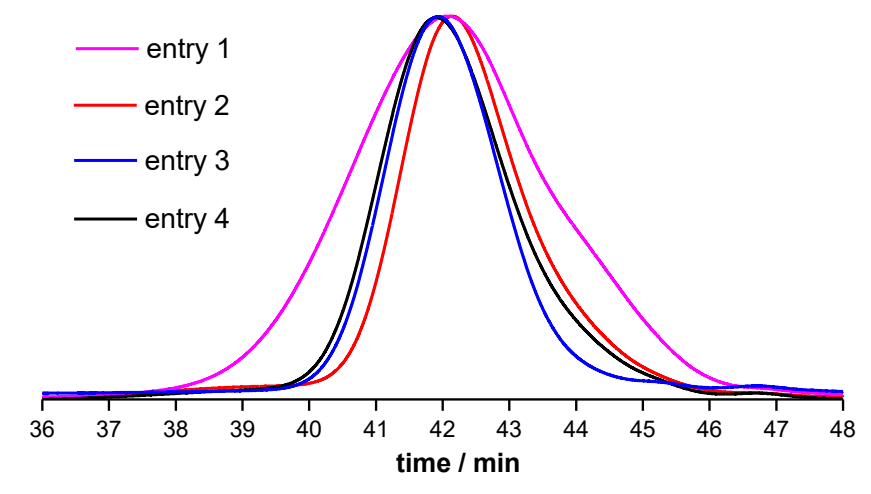

Figure S7. SEC traces for the effect of different CTAs on the polymerization of monomer 3. 
Table S4. Solvent effect on the polymerization of monomer 3.<smiles>C=CC(=O)N([13CH3])C/C=C/C(C)=O</smiles>

3

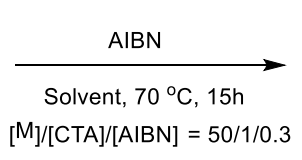

$[\mathrm{M}] /[\mathrm{CTA}] /[\mathrm{AIBN}]=50 / 1 / 0.3$

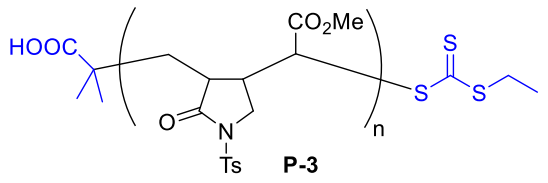

$\mathbf{P}-3$

\begin{tabular}{|c|c|c|c|c|c|}
\hline Entry & Solvent ${ }^{a}$ & Conversion $^{b}$ & $M_{\mathrm{n} \text { (theo) }}{ }^{c}$ & $M_{\mathrm{n}(\mathrm{SEC})}{ }^{d}$ & $M_{\mathrm{w}^{\prime}} / M_{\mathrm{n}}{ }^{d}$ \\
\hline 1 & DMF & $83 \%$ & 13600 & 6500 & 1.18 \\
\hline 2 & DMSO & $90 \%$ & 14800 & 5200 & 1.09 \\
\hline 3 & Dioxane & $81 \%$ & 13300 & 6400 & 1.21 \\
\hline 4 & Toluene & $87 \%$ & 14300 & 6800 & 1.16 \\
\hline $5^{e}$ & Toluene & $91 \%$ & 29700 & 11500 & 1.24 \\
\hline
\end{tabular}

${ }^{a}$ Experimental conditions: $[\mathbf{M}]=0.2 \mathrm{M}, 70^{\circ} \mathrm{C}$ under nitrogen for $15 \mathrm{~h}$, unless otherwise noted. ${ }^{b}$ Monomer conversion was determined by ${ }^{1} \mathrm{H}$ NMR spectroscopy. ${ }^{C}$ Theoretical molecular weight was calculated using the following equation: $M_{\mathrm{n} \text { (theo) }}=[\mathrm{M}]_{0} /[\mathrm{CTA}]_{0} \mathrm{X} M \mathrm{MW}^{\mathrm{M}}$ $X$ conversion + $\mathrm{MW}^{\mathrm{CTA}}$, where $[\mathrm{M}]_{0},[\mathrm{CTA}]_{0}, \mathrm{MW}^{\mathrm{M}}$, and $\mathrm{MW}^{\mathrm{CTA}}$ correspond to initial monomer concentration, initial CTA concentration, molar mass of monomer repeat unit, and molar mass of CTA, respectively. ${ }^{d}$ Molecular weight and polydispersity index $\left(M_{\mathrm{w}} / M_{\mathrm{n}}\right)$ were determined by SEC analysis calibrated to polystyrene standards. ${ }^{e}[\mathrm{M}] /[\mathrm{CTA}] /[\mathrm{AIBN}]=100 / 1 / 0.3,20 \mathrm{~h}$.

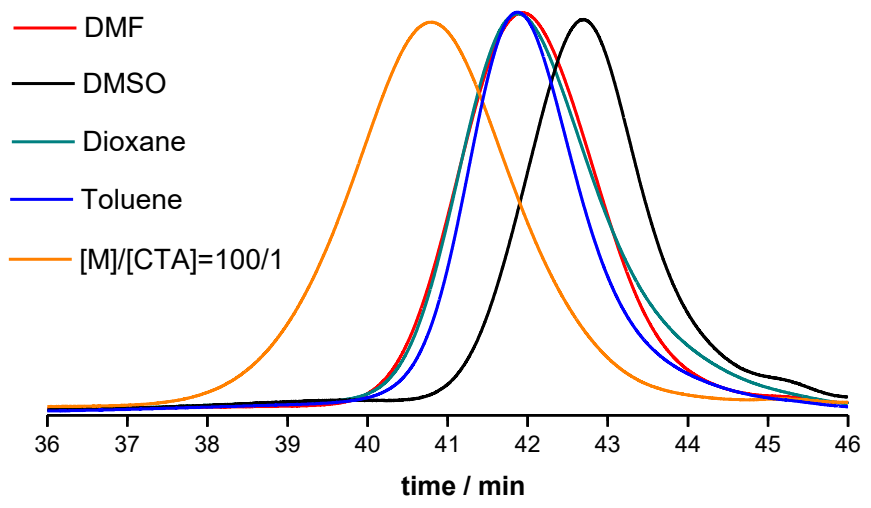

Figure S8. SEC traces for the effect of different solvent on the polymerization of monomer 3 . 
Table S5. Concentration effect on the polymerization of monomer 3 .

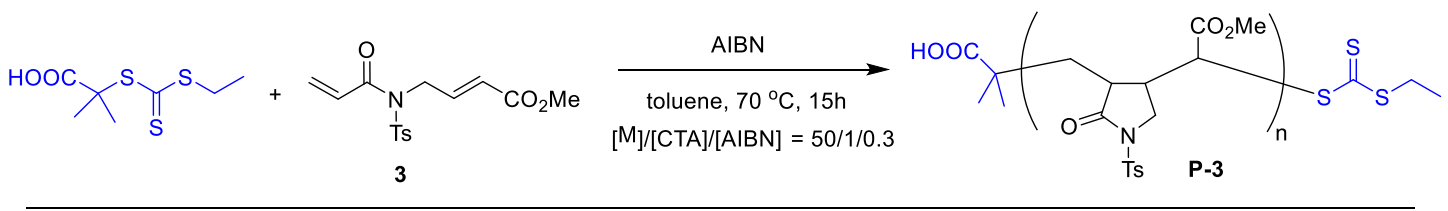

\begin{tabular}{|c|c|c|c|c|c|}
\hline Entry & Concentration of monomer ${ }^{a}$ & Conversion $^{b}$ & $M_{\mathrm{n} \text { (theo) }}{ }^{c}$ & $M_{\mathrm{n}(\mathrm{SEC})^{d}}$ & $M_{\mathrm{w}} / M_{\mathrm{n}}{ }^{d}$ \\
\hline 1 & $0.1 \mathrm{M}$ & $79 \%$ & 13000 & 6100 & 1.17 \\
\hline 2 & $0.2 \mathrm{M}$ & $87 \%$ & 14300 & 6800 & 1.16 \\
\hline 3 & $0.4 \mathrm{M}$ & $>95 \%$ & 16400 & 7500 & 1.14 \\
\hline \multicolumn{6}{|c|}{$\begin{array}{l}{ }^{a} \text { Experimental conditions: } 70^{\circ} \mathrm{C} \text { under nitrogen for } 15 \mathrm{~h} \text {, unless otherwise noted. }{ }^{b} \text { Monomer conversion was determined by }{ }^{1} \mathrm{H} \text { NMR } \\
\text { spectroscopy. }{ }^{c} \text { Theoretical molecular weight was calculated using the following equation: } M_{\mathrm{n} \text { (theo) }}=[\mathrm{M}]_{0} /[\mathrm{CTA}]_{0} \mathrm{X} \mathrm{MW} \mathrm{M}^{\mathrm{M}} \mathrm{X} \\
\text { conversion }+\mathrm{MW} \mathrm{WTA}^{\mathrm{CTA}} \text {, where }[\mathrm{M}]_{0},[\mathrm{CTA}]_{0}, \mathrm{MW}^{\mathrm{M}} \text {, and } \mathrm{MW} \mathrm{WTA}^{\mathrm{CTA}} \text { correspond to initial monomer concentration, initial CTA concentration, } \\
\text { molar mass of monomer repeat unit, and molar mass of CTA, respectively. }{ }^{d} \text { Molecular weight and polydispersity index }\left(M_{\mathrm{w}} / M_{\mathrm{n}}\right) \\
\text { were determined by SEC analysis calibrated to polystyrene standards. }\end{array}$} \\
\hline
\end{tabular}

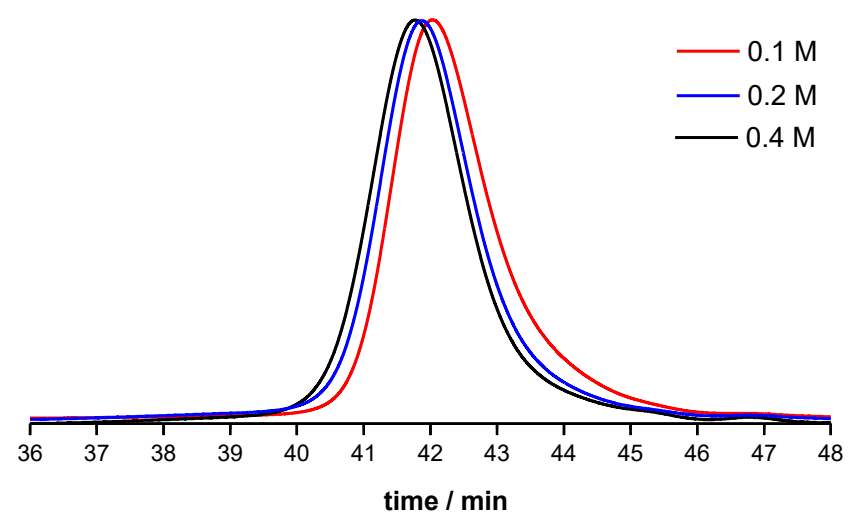

Figure S9. SEC traces for the effect of different concentration on the polymerization. 
Kinetic study on the polymerization of monomer 3.

(a)

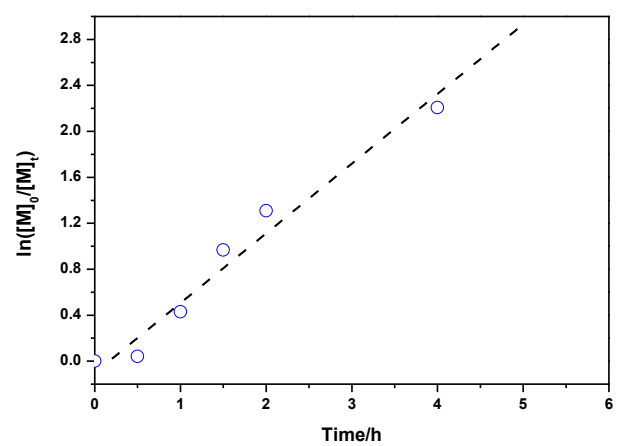

(b)

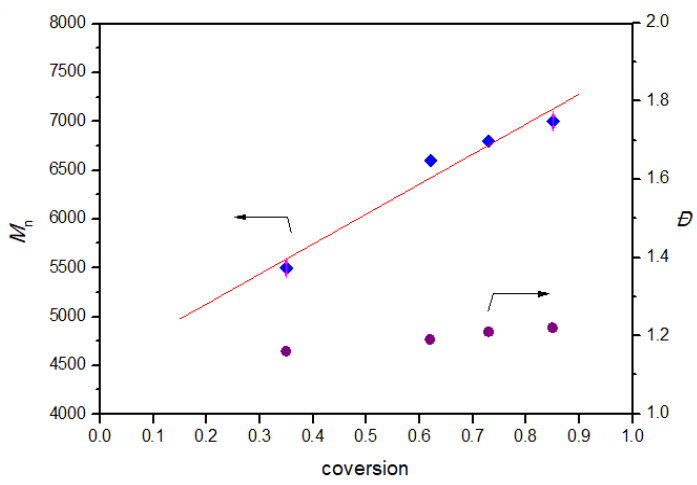

(c)

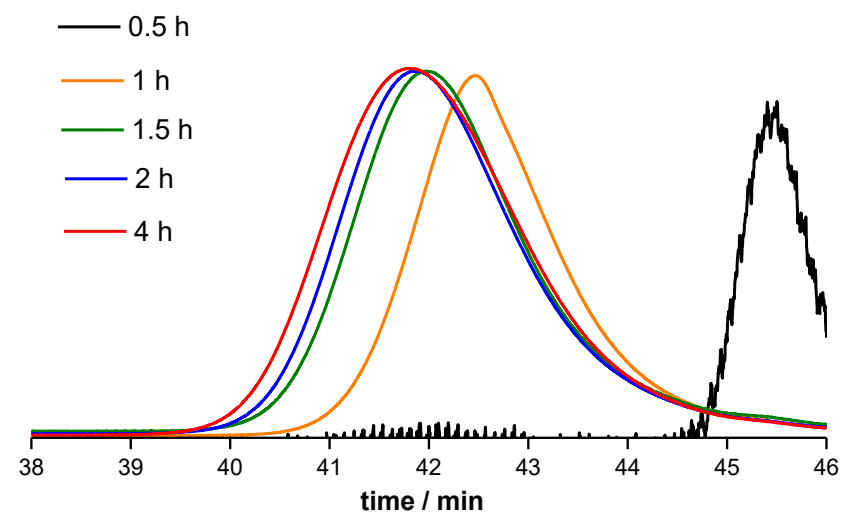

Figure S10. Kinetic study on the polymerization of monomer $\mathbf{3}$ (reaction condition is the same as shown in Table $\mathbf{S} 4$ entry3). (a) A linear relationship between $\ln \left([\mathrm{M}]_{0} /[\mathrm{M}]_{\mathrm{t}}\right.$ ) and reaction time was observed. (b) Plot of $M_{\mathrm{n}}$ and $Đ$ versus monomer conversion. (c) SEC traces of different times. 
Scheme S6. Radical reaction of compound 4.<smiles>C=CC(=O)N([13CH3])C/C=C/CS(=O)(=O)C(C)COCC</smiles><smiles>C=CC1CN([12F])C(=O)C1CC(C)COCC</smiles>

A $10 \mathrm{~mL}$ Schlenk vial equipped with a stir bar was charged with 4 (88.7 mg, $0.2 \mathrm{mmol})$, AIBN (1.64 $\mathrm{mg}, 0.01 \mathrm{mmol})$ and DMF $(1.0 \mathrm{~mL})$. The vial was sealed and the solution was deoxygenated via three freeze-pump-thaw cycles and then backfilled with nitrogen. The reaction mixture was heated at $70{ }^{\circ} \mathrm{C}$ for $15 \mathrm{~h}$, yielding the product 5 as a white solid (63.2 mg, 83\% yield). ${ }^{1} \mathrm{H}$ NMR (600 MHz, $\left.\mathrm{CDCl}_{3}\right): \delta 7.89(\mathrm{~d}, J=8.4 \mathrm{~Hz}, 2 \mathrm{H}), 7.32(\mathrm{~d}, J=8.5 \mathrm{~Hz}, 2 \mathrm{H}), 5.65(\mathrm{dtd}, J=17.1,10.3,8.2 \mathrm{~Hz}, 1 \mathrm{H})$, 5.26-5.13 (m, 2H), 4.13-3.97 (m, 3H), $3.39(\mathrm{td}, J=9.9,2.3 \mathrm{~Hz}, 1 \mathrm{H}), 2.97-2.84(\mathrm{~m}, 0.5 \mathrm{H}), 2.75(\mathrm{~h}$, $J=7.1 \mathrm{~Hz}, 0.5 \mathrm{H}), 2.62(\mathrm{dq}, J=17.7,8.0 \mathrm{~Hz}, 1 \mathrm{H}), 2.43(\mathrm{~s}, 3 \mathrm{H}), 2.38-2.28(\mathrm{~m}, 1 \mathrm{H}), 2.08(\mathrm{dt}, J=$ 14.6, 7.4 Hz, 0.5H), 1.80 (ddd, $J=14.4,9.6,4.9 \mathrm{~Hz}, 0.5 \mathrm{H}), 1.58(\mathrm{ddd}, J=13.9,8.5,5.1 \mathrm{~Hz}, 0.5 \mathrm{H}$ ), $1.45(\mathrm{dt}, J=14.0,6.7 \mathrm{~Hz}, 0.5 \mathrm{H}), 1.19(\mathrm{td}, J=7.1,3.7 \mathrm{~Hz}, 3 \mathrm{H}), 1.10(\mathrm{t}, J=6.9 \mathrm{~Hz}, 3 \mathrm{H}) ;{ }^{13} \mathrm{C} \mathrm{NMR}$ $\left(150 \mathrm{MHz}, \mathrm{CDCl}_{3}\right): \delta 176.0,175.9,174.3,173.8,145.3,145.3,135.9,135.5,135.3,135.2,129.8$, 128.1, 118.9, 118.9, 60.5, 60.5, 49.9, 49.9, 46.2, 46.0, 43.8, 43.8, 36.7, 36.3, 32.9, 32.7, 21.8, 21.8, 18.0, 17.4, 14.3, 14.3.; HRMS (m/z) $[\mathrm{M}+\mathrm{H}]^{+}$calc'd for $\mathrm{C}_{19} \mathrm{H}_{26} \mathrm{NO}_{5} \mathrm{~S}, 380.1526$, found 380.1518 .

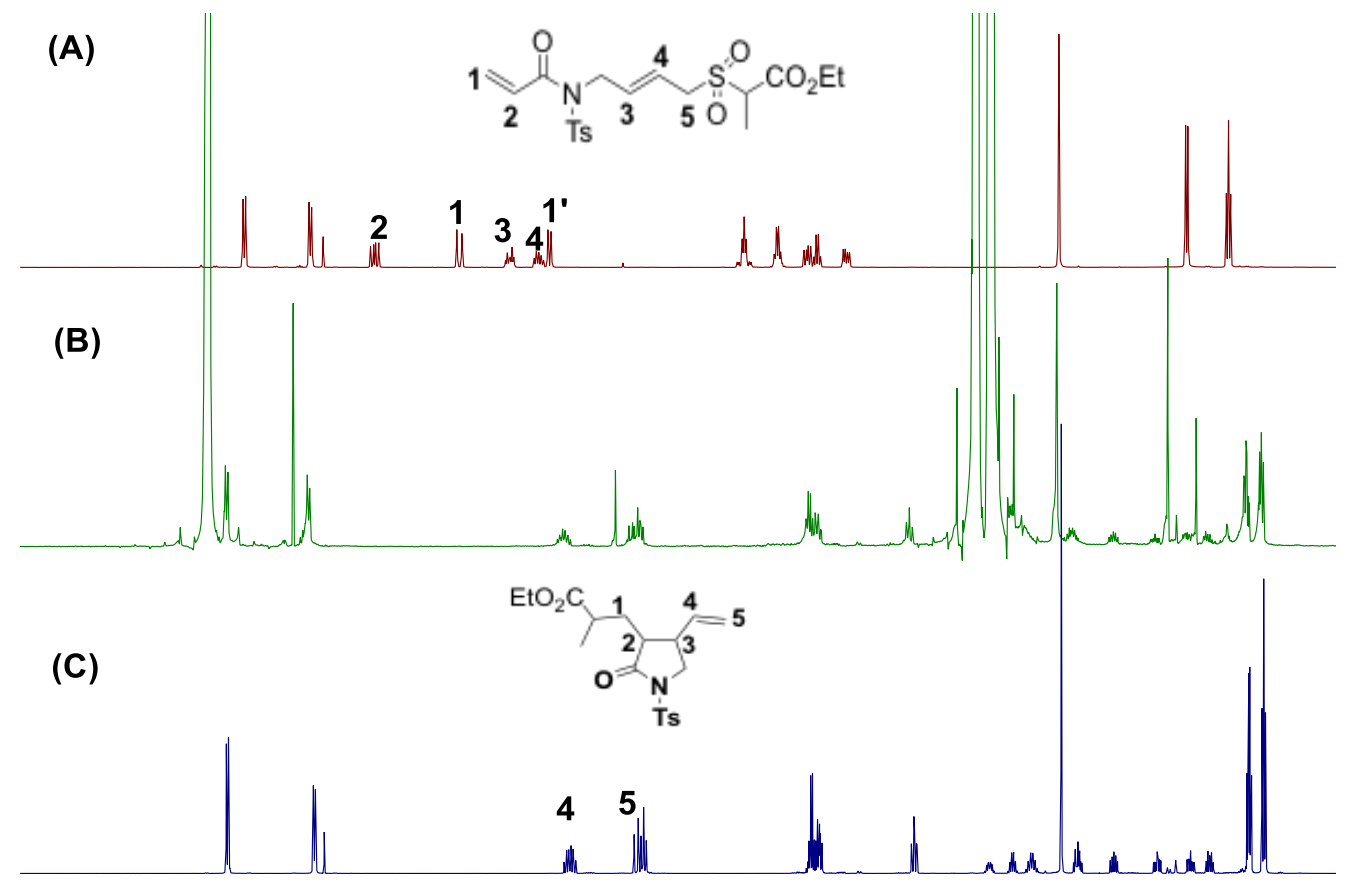

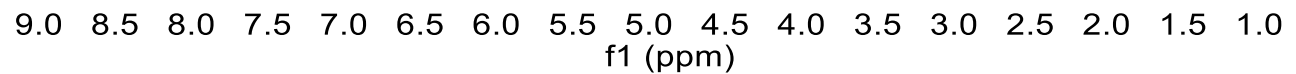

Figure S11. ${ }^{1} \mathrm{H}$ NMR spectra of (A) 4, (B) crude NMR and (C) 5. 


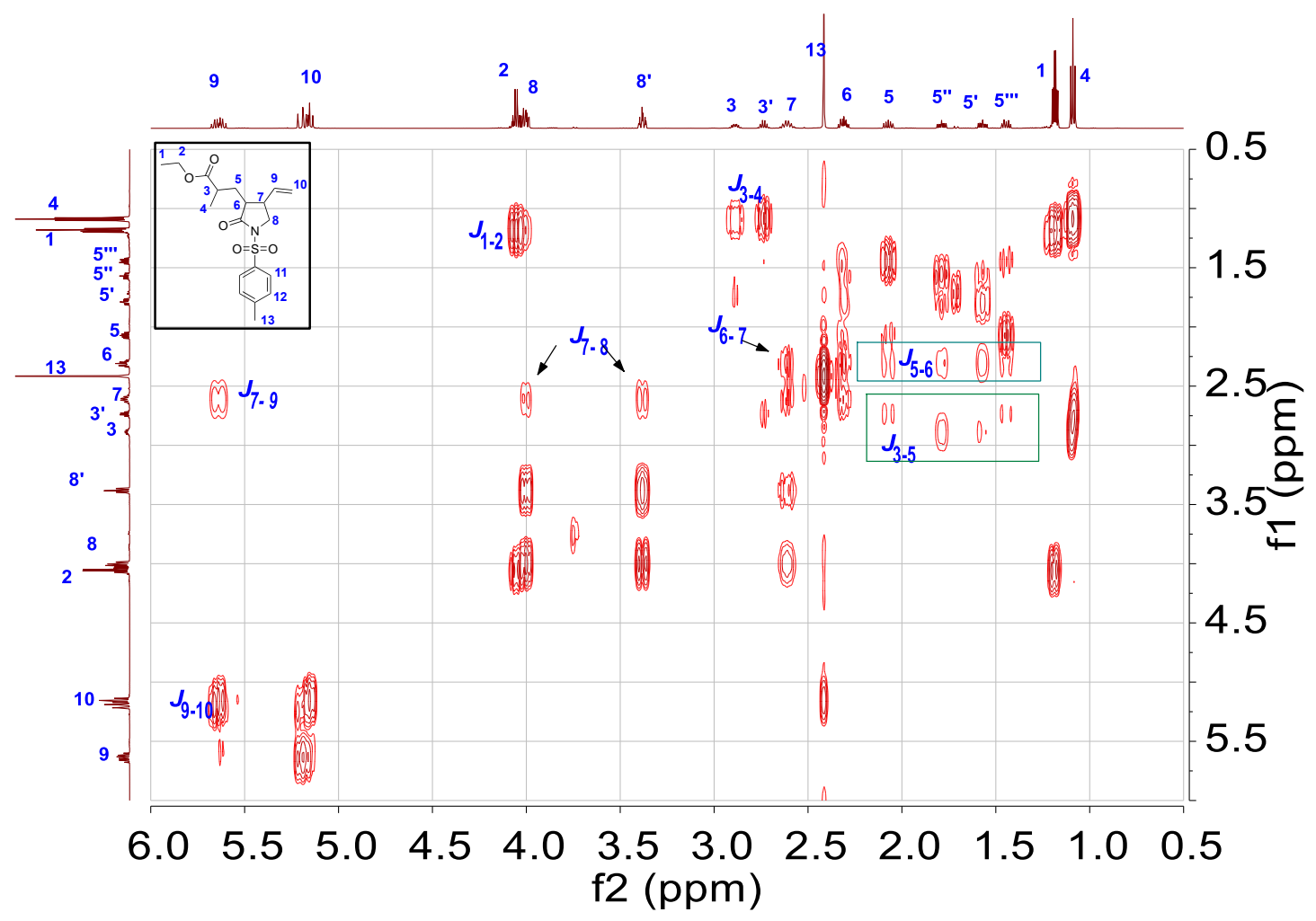

Figure S12. COSY spectra of product 5.

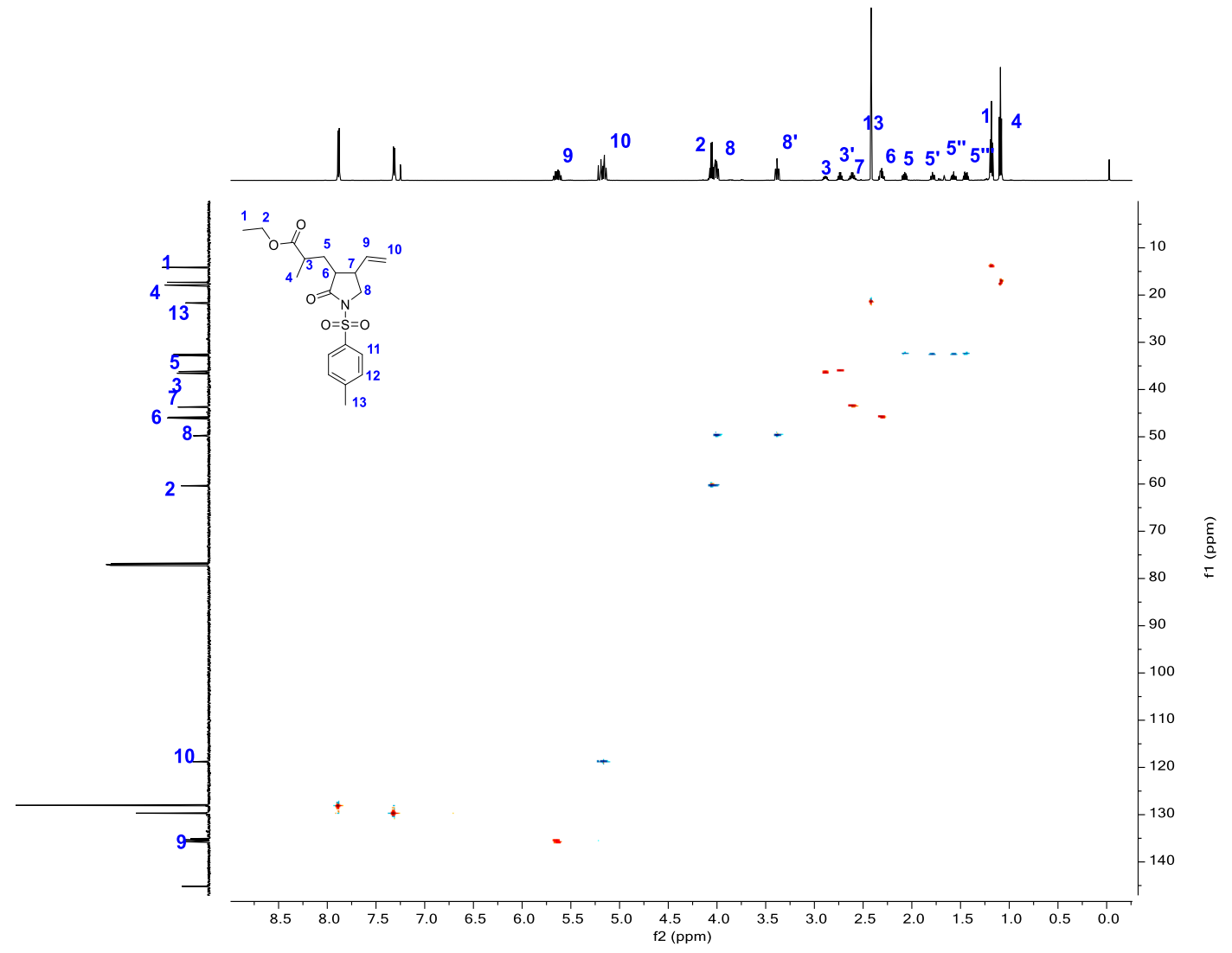

Figure S13. HSQC spectra of product 5. 


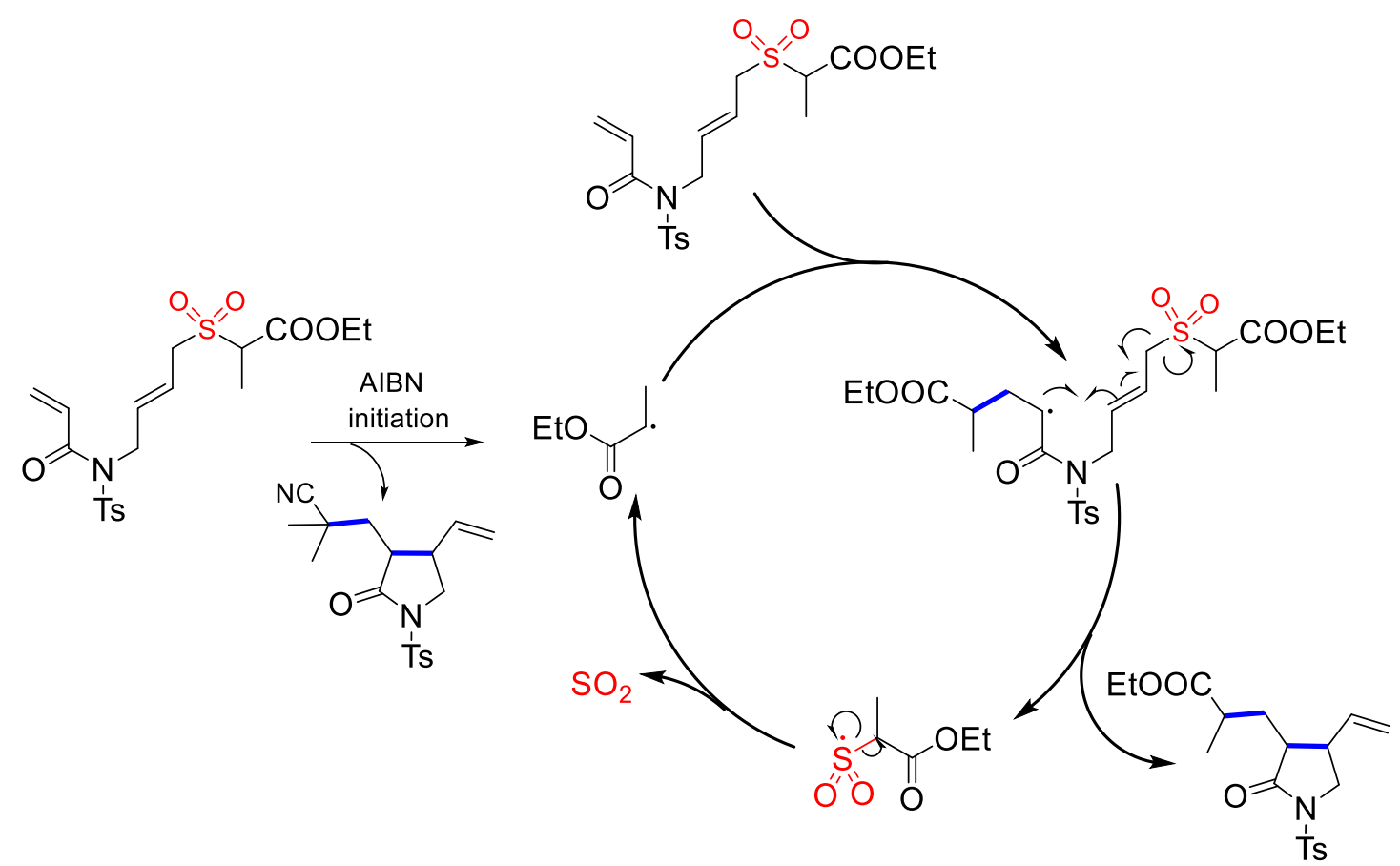

Figure S14. Proposed mechanism for radical reaction of compound 4. 


\section{DFT calculation:}
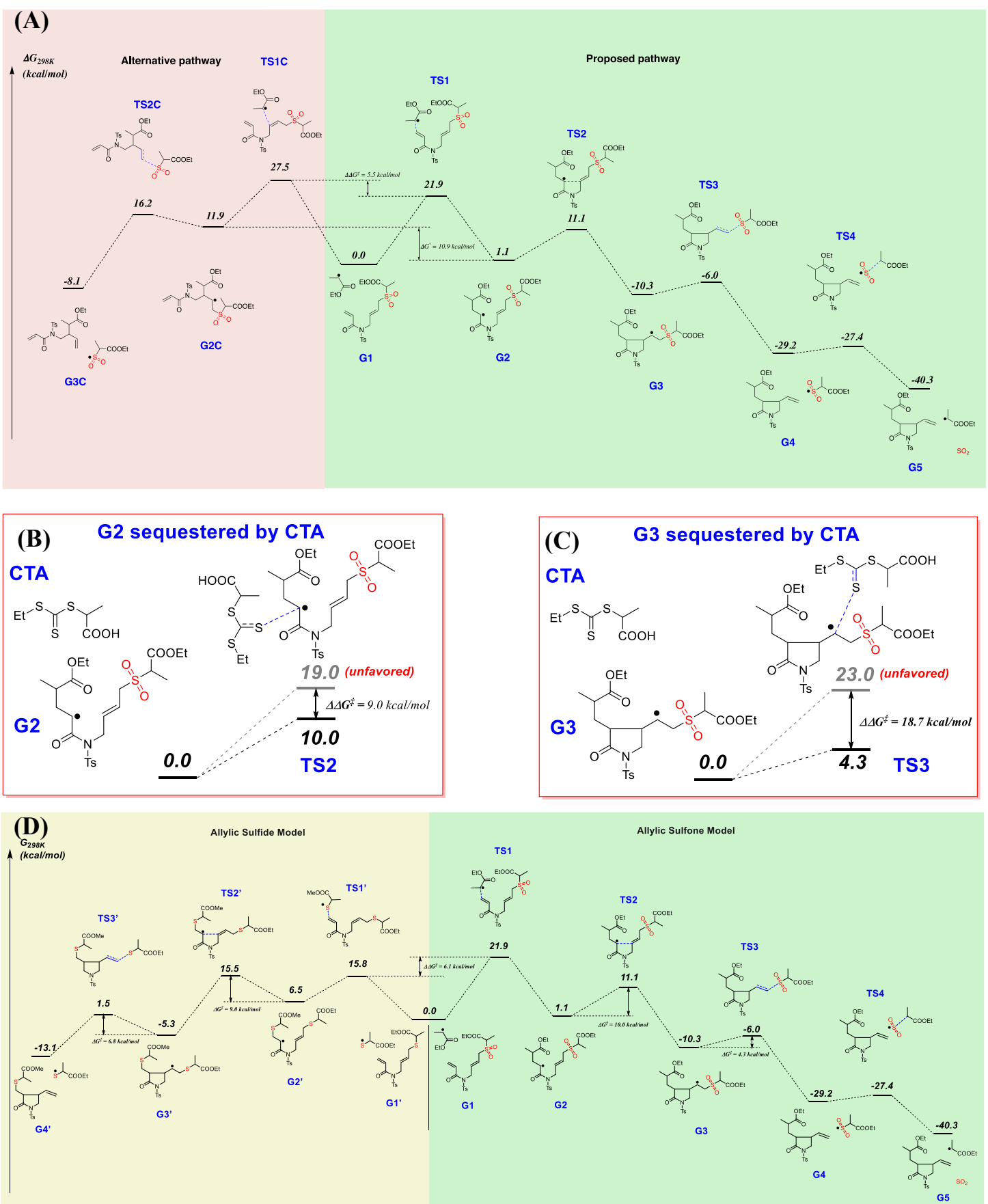

Figure S15. DFT calculation. (A) Relative Gibbs free energies of the model reaction of RCROP. (B) and (C) Relative Gibbs free energy diagram of intermediates sequestered by CTA. (D) Comparison between 1,6-diene-fused allylic sulfone model reaction and 1,6-diene-fused allylic sulfide model reaction.

Discussion: Our DFT calculations show that radical addition of the alkyl radical to the terminal vinyl group of the model compound $\mathbf{4}$ is the rate-limiting step with a Gibbs free energy barrier of $21.9 \mathrm{kcal} / \mathrm{mol}$ (G1-TS1). In comparison, an alternative reaction pathway in which the alkyl radical instead adds to the internal olefin of 4 has a Gibbs free energy barrier of $27.5 \mathrm{kcal} / \mathrm{mol}$ (G1-TS1C) (Figure S15A). Also, the Gibbs free energy of G5 with respect to the starting material is -40.3 
$\mathrm{kcal} / \mathrm{mol}$ (G1 - G5), whereas the exergonicity of forming G3C is only $-8.1 \mathrm{kcal} / \mathrm{mol}(\mathbf{G 1}-\mathbf{G 3 C})$. Consequently, these results suggest that the alternative pathway is both kinetically and thermodynamically disfavored compared to the proposed pathway.

Furthermore, the Gibbs free energy barrier of the 5-exo-trig cyclization of G2 is $9.0 \mathrm{kcal} / \mathrm{mol}$ lower than the corresponding energy barrier in a competing process in which $\mathbf{G} 2$ is sequestered by CTA2 (Figure S15B). Likewise, the Gibbs free energy barrier of $4.3 \mathrm{kcal} / \mathrm{mol}$ of the $\beta$-elimination involving the sulfonyl radical $\mathbf{G 3}$ is significantly lower than the competing $\mathbf{G 3}$ sequestration (18.7 $\mathrm{kcal} / \mathrm{mol}$ ) by CTA2 (Figure S15C). These results indicate that the competing CTA sequestration of the intermediate radical species during the radical cascade process is energetically disfavored. G3 formed from the 5-exo-trig cyclization of 1,6-diene is predisposed to the subsequent $\beta$-elimination, indicated by the low activation Gibbs free energy of $4.3 \mathrm{kcal} / \mathrm{mol}(\mathbf{G 3}-\mathbf{T S 3})$, and the high exergonicity by $18.9 \mathrm{kcal} / \mathrm{mol}(\mathbf{G 3}-\mathbf{G 4})$.

In the 1,6-diene-fused allylic sulfide model reaction, the activation Gibbs free energy of the thiyl radical addition to the terminal vinyl group is $15.8 \mathrm{kcal} / \mathrm{mol}$ (G1' - TS1') (Figure S15D), indicating that it is the rate-limiting step. Meanwhile, the 5-exo-trig cyclization has an activation Gibbs free energy of $\left.9.0 \mathrm{kcal} / \mathrm{mol}^{(\mathbf{G} 2}{ }^{\prime}-\mathbf{T S 2}^{\prime}\right)$ and is exergonic by $11.8 \mathrm{kcal} / \mathrm{mol}$ (G2'- G3'). The relatively low activation energy and exergonicity, as well as the formation of G3' that is predisposed for the subsequent $\beta$-elimination (G3 - TS3', low energy barrier of $6.8 \mathrm{kcal} / \mathrm{mol}$ ), allow the 5 -exo-trig cyclization serve as the driving force for the RCROP.

In summary, our computations support the proposed radical cascade pathway and highlight the significance of 5-exo-trig cyclization of 1,6-diene in driving the cascade reactions. 
Scheme S7. Radical ring-closing/ring-opening cascade polymerization of macrocyclic monomer 10.

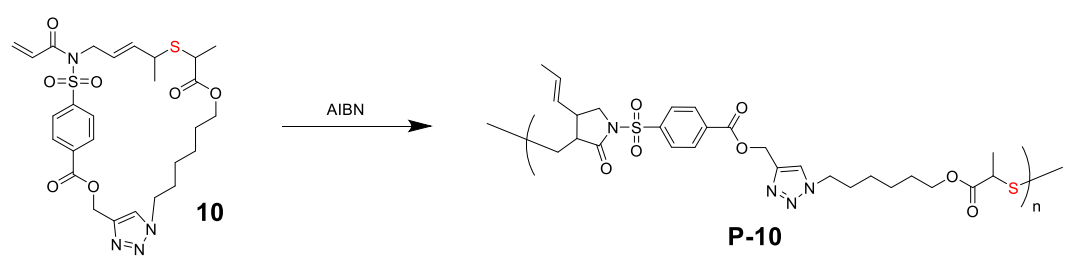

A $10 \mathrm{~mL}$ Schlenk vial equipped with a stir bar was charged with macrocyclic monomer 10 (23.5 $\mathrm{mg}, 0.2 \mathrm{M},[\mathrm{M}] /[\mathrm{AIBN}]=50)$, followed by the stock DMF solution of $8 \mathrm{mM}$ AIBN $(99.5 \mu \mathrm{L})$ and dioxane $(99.5 \mu \mathrm{L})$. The vial was sealed. The solution was deoxygenated via three freeze-pump-thaw cycles, backfilled with nitrogen, and then heated at $85{ }^{\circ} \mathrm{C}$ for $24 \mathrm{~h}$. After reaction, the vial was cooled by ice bath and open to air to stop the polymerization. The reaction mixture was diluted with minimum amount of DCM and precipitated in diethyl ether. The obtained solid was re-dissolved with a minimum amount of DCM for further precipitation, yielding the polymer which was then characterized using SEC $\left(M_{\mathrm{n}}=17600, \emptyset=2.09\right),{ }^{1} \mathrm{H}-\mathrm{NMR}$ and ${ }^{13} \mathrm{C}-\mathrm{NMR} .{ }^{1} \mathrm{H}$ NMR $(500 \mathrm{MHz}$, $\left.\mathrm{CDCl}_{3}\right): \delta 8.16(\mathrm{~d}, J=7.4 \mathrm{~Hz}, 2 \mathrm{H}), 8.05(\mathrm{~d}, J=6.5 \mathrm{~Hz}, 2 \mathrm{H}), 7.73(\mathrm{~s}, 1 \mathrm{H}), 5.71-5.57(\mathrm{~m}, 1 \mathrm{H}), 5.48$ (s, 2H), 5.35-5.02 (m, 1H), $4.36(\mathrm{t}, J=6.3 \mathrm{~Hz}, 2 \mathrm{H}), 4.14-3.94(\mathrm{~m}, 3 \mathrm{H}), 3.48-3.23(\mathrm{~m}, 2 \mathrm{H}), 2.99$ $2.72(\mathrm{~m}, 3 \mathrm{H}), 2.61-2.41(\mathrm{~m}, 1 \mathrm{H}), 2.00-1.84(\mathrm{~m}, 2 \mathrm{H}), 1.80-1.54(\mathrm{~m}, 5 \mathrm{H}), 1.45-1.21(\mathrm{~m}, 7 \mathrm{H}) .{ }^{13} \mathrm{C}$ NMR (125 MHz, $\left.\mathrm{CDCl}_{3}\right): \delta 173.0,172.7,164.9,142.3,142.1,142.0,134.9,130.6,130.5,128.2$, 128.0, 127.8, 124.2, 65.1, 65.0, 58.9, 50.4, 49.9, 49.5, 42.7, 42.1, 40.9, 40.8, 30.2, 29.3, 29.3, 28.5, $26.2,25.4,18.1,17.2,17.2$.

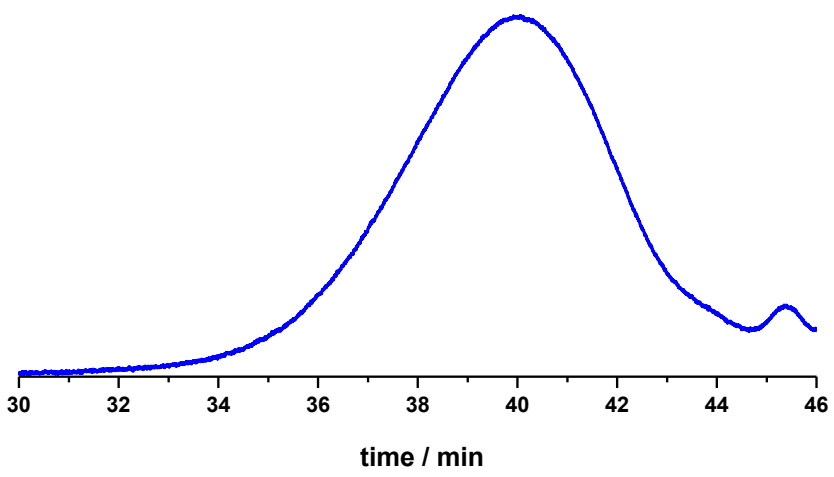

Figure S16. SEC traces of the polymerization of macrocyclic monomer 10. 
Scheme S8. Effect of CTA on the polymerization of macrocyclic monomer $\mathbf{1 0 .}$
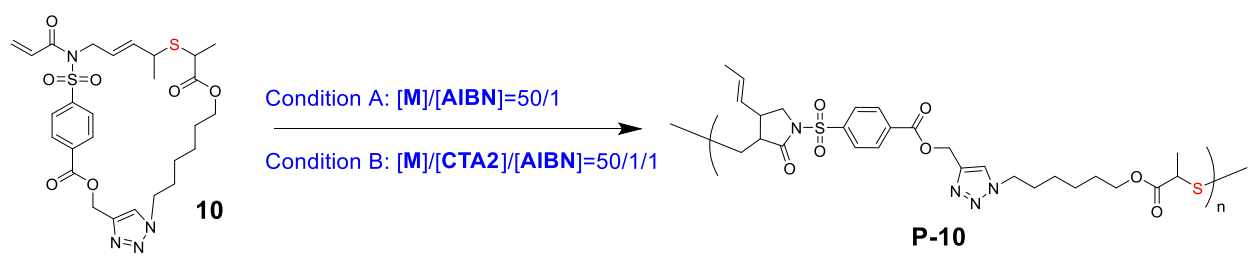

A $4 \mathrm{~mL}$ vial was charged with macrocyclic monomer $\mathbf{1 0}(68.0 \mathrm{mg})$, followed by the stock DMF solution of $8 \mathrm{mM}$ AIBN $(287.8 \mu \mathrm{L})$ and DMF $(640.2 \mu \mathrm{L})$. The solution was divided into two Schlenk vials. The one (condition A) was added DMF $(72 \mu \mathrm{L})$ and dioxane $(532 \mu \mathrm{L})$. The other (condition B) was added the stock DMF solution of 16 mM CTA2 $(72 \mu \mathrm{L})$ and dioxane $(532 \mu \mathrm{L})$. The vials were sealed. The solution was deoxygenated via three freeze-pump-thaw cycles, backfilled with nitrogen, and then heated at $85^{\circ} \mathrm{C}$ for $28 \mathrm{~h}$. After reaction, the vials were cooled by ice bath and open to air to stop the polymerization. ${ }^{1} \mathrm{H}$ NMR shown all the monomer conversion were more than $95 \%$. The reaction mixture was diluted with minimum amount of DCM and precipitated in diethyl ether. The obtained solid was re-dissolved with a minimum amount of DCM for further precipitation, yielding the polymer which was then characterized using SEC: (condition A: $M_{\mathrm{n}}=8500, Ð=1.62$; condition B: $M_{\mathrm{n}}=7700, Ð=1.60$ ). Both $M_{\mathrm{n}}$ and $Ð$ have not much change, suggest that the CTA reagent have little effect on the polymerization of macrocyclic monomer $\mathbf{1 0}$.

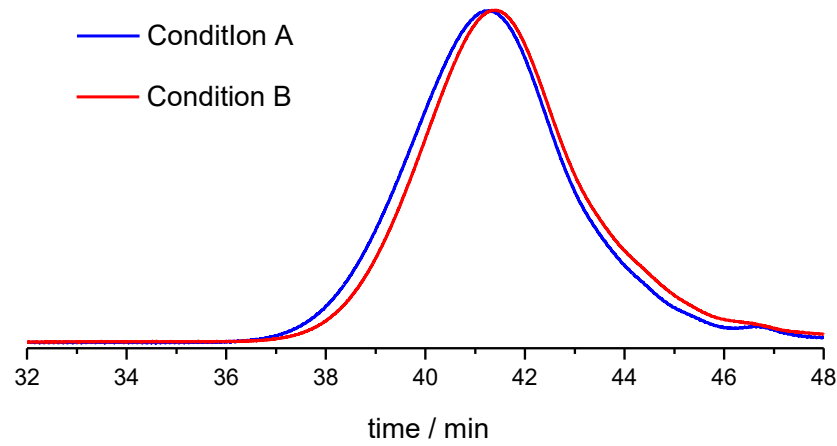

Figure S17. SEC traces of P-10 showed that adding CTA had little effect on the polymerization of 10. 
Scheme S9. General procedure of radical ring-closing/ring-opening cascade polymerization in the presence of CTA.

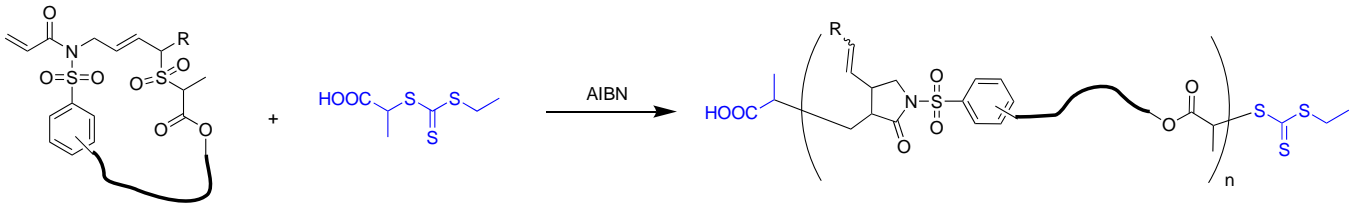

All polymerization reactions were performed under nitrogen atmosphere using a standard Schlenk technique. The stock solution 2-(((ethylthio)carbonothioyl)thio)propanoic acid (CTA2) and stock solution of AIBN are prepared in degassed solvent at either 8 or $16 \mathrm{mM}$ depending on the reaction. A typical procedure for the preparation of $\mathbf{P - 1 1}$ was given below as an example. A $10 \mathrm{~mL}$ Schlenk vial equipped with a stir bar was charged with macrocyclic monomer 11 (50 mg, $80.2 \mu \mathrm{mol}, 0.1 \mathrm{M})$, followed by the stock solution of $16 \mathrm{mM}$ CTA2 $(100.3 \mu \mathrm{L}), 8 \mathrm{mM}$ AIBN $(20.1 \mu \mathrm{L})$ and solvent $(681.6 \mu \mathrm{L})$. The vial was sealed. The solution was deoxygenated via three freeze-pump-thaw cycles, backfilled with nitrogen, and then heated at $85{ }^{\circ} \mathrm{C}$ for a given time. After reaction, the vial was cooled by ice bath and open to air to stop the polymerization. The reaction mixture was diluted with minimum amount of DCM and precipitated in diethyl ether/methanol (V/V 5:1). The obtained solid was re-dissolved with a minimum amount of DCM for further precipitation, yielding the polymer which was then characterized using SEC, ${ }^{1} \mathrm{H}-\mathrm{NMR}$ and ${ }^{13} \mathrm{C}-\mathrm{NMR}$.

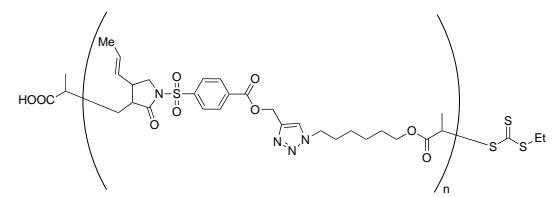

P-11: ${ }^{1} \mathrm{H}$ NMR (500 MHz, $\left.\mathrm{CDCl}_{3}\right): \delta 8.17(\mathrm{~d}, J=8.0 \mathrm{~Hz}, 2 \mathrm{H}), 8.05(\mathrm{~d}, J=8.1 \mathrm{~Hz}, 2 \mathrm{H}), 7.72(\mathrm{~s}$, $1 \mathrm{H}), 5.63(\mathrm{tt}, J=14.1,6.4 \mathrm{~Hz}, 1 \mathrm{H}), 5.49(\mathrm{~s}, 2 \mathrm{H}), 5.32-5.04(\mathrm{~m}, 1 \mathrm{H}), 4.36(\mathrm{t}, J=7.1 \mathrm{~Hz}, 2 \mathrm{H}), 4.08$ $3.85(\mathrm{~m}, 3 \mathrm{H}), 3.44-3.23(\mathrm{~m}, 1 \mathrm{H}), 2.96-2.71(\mathrm{~m}, 1 \mathrm{H}), 2.65-2.49(\mathrm{~m}, 1 \mathrm{H}), 2.35-2.22(\mathrm{~m}, 1 \mathrm{H}), 2.11-$ $1.99(\mathrm{~m}, 0.5 \mathrm{H}), 1.98-1.86(\mathrm{~m}, 2 \mathrm{H}), 1.85-1.75(\mathrm{~m}, 0.5 \mathrm{H}), 1.73-1.19(\mathrm{~m}, 10 \mathrm{H}), 1.19-1.00(\mathrm{~m}, 3 \mathrm{H})$. ${ }^{13} \mathrm{C}$ NMR (125 MHz, $\left.\mathrm{CDCl}_{3}\right)$ : $\delta$ 176.0, 175.9, 174.6, 174.2, 164.9, 142.3, 142.1, 142.1, 134.8, 130.5, 130.4, 130.3, 128.4, 128.2, 128.0, 124.1, 64.3, 58.9, 50.4, 46.4, 46.2, 43.2, 43.1, 36.5, 36.5, 32.7, $32.7,30.3,28.5,28.5,26.2,25.5,25.4,18.1,18.0,17.5$.

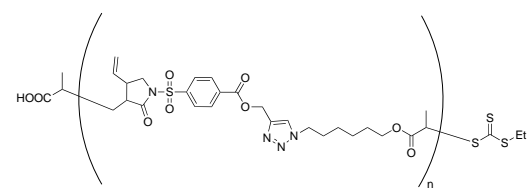

P-12: ${ }^{1} \mathrm{H}$ NMR (500 MHz, $\left.\mathrm{CDCl}_{3}\right): \delta 8.17(\mathrm{~d}, J=7.8 \mathrm{~Hz}, 2 \mathrm{H}), 8.06(\mathrm{~d}, J=7.8 \mathrm{~Hz}, 2 \mathrm{H}), 7.72(\mathrm{~s}$, $1 \mathrm{H}), 5.65(\mathrm{dq}, J=18.4,10.3 \mathrm{~Hz}, 1 \mathrm{H}), 5.49(\mathrm{~s}, 2 \mathrm{H}), 5.27-5.06(\mathrm{~m}, 2 \mathrm{H}), 4.35(\mathrm{t}, J=6.1 \mathrm{~Hz}, 2 \mathrm{H})$, $4.13-3.85$ (m, 3H), $3.43(\mathrm{td}, J=9.8,5.3 \mathrm{~Hz}, 1 \mathrm{H}), 3.00-2.70(\mathrm{~m}, 1 \mathrm{H}), 2.70-2.56(\mathrm{~m}, 1 \mathrm{H}), 2.40-2.27$ $(\mathrm{m}, 1 \mathrm{H}), 2.07(\mathrm{dt}, J=14.5,7.3 \mathrm{~Hz}, 0.5 \mathrm{H}), 1.99-1.87(\mathrm{~m}, 2 \mathrm{H}), 1.81(\mathrm{td}, J=12.0,9.8,4.9 \mathrm{~Hz}, 0.5 \mathrm{H})$, $1.70-1.18(\mathrm{~m}, 7 \mathrm{H}), 1.10(\mathrm{t}, J=7.1 \mathrm{~Hz}, 3 \mathrm{H}) .{ }^{13} \mathrm{C} \mathrm{NMR}\left(500 \mathrm{MHz}, \mathrm{CDCl}_{3}\right): \delta 176.0,175.8,174.4$, 174.0, 164.9, 142.3, 142.1, 142.0, 135.6, 135.2, 134.9, 130.5, 128.2, 128.2, 124.2, 119.3, 64.3, 58.9, $50.4,50.0,50.0,46.1,46.0,44.0,43.9,36.5,36.5,32.7,30.3,28.5,26.2,25.5,25.5,18.1,17.5$. 


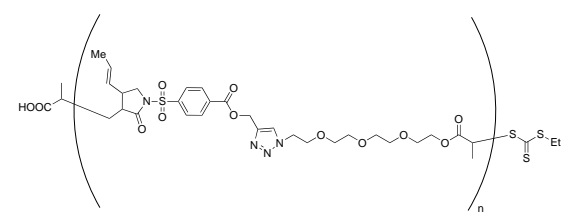

P-13: ${ }^{1} \mathrm{H}$ NMR (500 MHz, $\left.\mathrm{CDCl}_{3}\right): \delta 8.17(\mathrm{~d}, J=8.0 \mathrm{~Hz}, 2 \mathrm{H}), 8.05(\mathrm{~d}, J=8.3 \mathrm{~Hz}, 2 \mathrm{H}), 7.89$ (s, $1 \mathrm{H}), 5.71-5.55(\mathrm{~m}, 1 \mathrm{H}), 5.48(\mathrm{~s}, 2 \mathrm{H}), 5.31-5.03(\mathrm{~m}, 1 \mathrm{H}), 4.55(\mathrm{t}, J=4.9 \mathrm{~Hz}, 2 \mathrm{H}), 4.25-4.07(\mathrm{~m}$, $2 \mathrm{H}), 3.96(\mathrm{t}, J=8.3 \mathrm{~Hz}, 1 \mathrm{H}), 3.88(\mathrm{t}, J=4.9 \mathrm{~Hz}, 2 \mathrm{H}), 3.74-3.42(\mathrm{~m}, 10 \mathrm{H}), 3.41-3.26(\mathrm{~m}, 1 \mathrm{H}), 2.94$ $2.68(\mathrm{~m}, 1 \mathrm{H}), 3.64-3.49(\mathrm{~m}, 1 \mathrm{H}), 2.37-2.24(\mathrm{~m}, 1 \mathrm{H}), 2.11-1.97(\mathrm{~m}, 0.5 \mathrm{H}), 1.83-1.73(\mathrm{~m}, 0.5 \mathrm{H})$, $1.73-1.26(\mathrm{~m}, 4 \mathrm{H}), 1.09(\mathrm{t}, J=7.6 \mathrm{~Hz}, 3 \mathrm{H}) .{ }^{13} \mathrm{C} \mathrm{NMR}\left(125 \mathrm{MHz}, \mathrm{CDCl}_{3}\right): \delta 175.9,175.8,174.6$, 174.2, 164.8, 142.1, 142.1, 134.9, 130.5, 130.3, 130.3, 128.4, 128.2, 128.0, 125.4, 70.6, 69.4, 69.2, $63.5,58.8,50.5,46.3,46.1,43.2,43.1,36.5,36.3,32.7,32.6,18.1,18.0,17.5$. 


\section{Conversion of monomer 11 analysis by NMR.}

Determination of monomer conversions for the polymerizations of monomer $\mathbf{1 1}$ was made based on the assumption that the integral of the peak at $\delta=4.55-4.32 \mathrm{ppm}$ (Peak b and b', Figure S18) corresponds to the methylene group of monomer and polymer P-11, and the integral of the peak at $\delta=4.68 \mathrm{ppm}$ (Peak a, Figure S18) corresponds to methylene group of unreacted monomer. When the integral of Peak b and b' is normalized to 1 , the monomer conversion $\alpha$ is calculated based on the following equation:

$$
\alpha=\left(1-I_{a}\right) \times 100 \%
$$

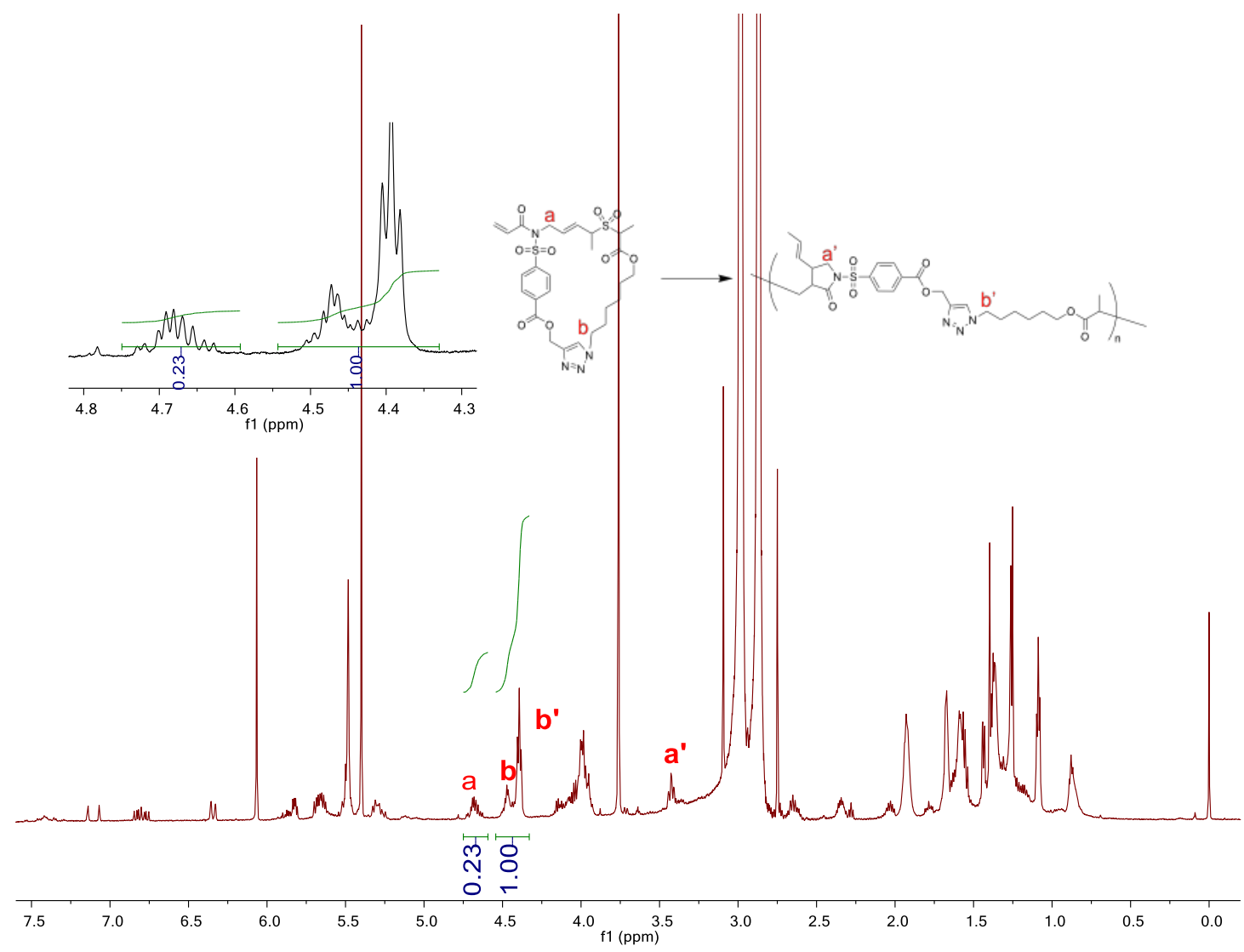

Figure S18. NMR determination of monomer conversion for the polymerization of monomer 11. When Peak $b$ and $b$ ' is normalized to 1 , the conversion is thus calculated as $\alpha=(1-$ $0.23) \times 100 \%=77 \%$. 
Table S6. Solvent effect on the polymerization of macrocyclic monomer 11.
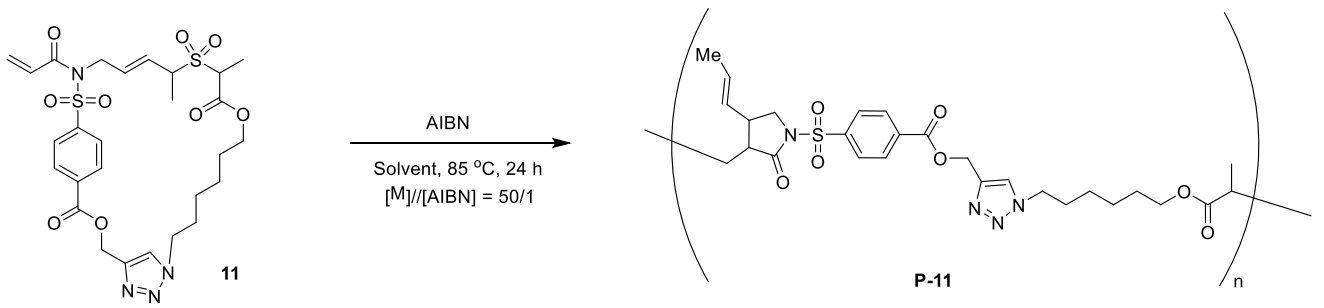

\begin{tabular}{|c|c|c|c|c|c|}
\hline Entry & Solvent ${ }^{a}$ & Temperature & Conversion ${ }^{b}$ & $M_{\mathrm{n}(\mathrm{SEC})^{c}}$ & $M_{\mathrm{w}} / M_{\mathrm{n}}{ }^{c}$ \\
\hline 1 & dioxane & $70^{\circ} \mathrm{C}$ & $58 \%$ & 7700 & 1.51 \\
\hline 2 & dioxane & $85^{\circ} \mathrm{C}$ & $83 \%$ & 7200 & 1.54 \\
\hline 3 & toluene & $85^{\circ} \mathrm{C}$ & $87 \%$ & 8900 & 3.13 \\
\hline 4 & DMF & $85^{\circ} \mathrm{C}$ & $87 \%$ & 23900 & 5.65 \\
\hline $5^{d}$ & dioxane/DMF & $85^{\circ} \mathrm{C}$ & $82 \%$ & 20100 & 3.04 \\
\hline
\end{tabular}

${ }^{a}$ Experimental conditions: $[\mathrm{M}]=0.2 \mathrm{M}, 85^{\circ} \mathrm{C}$ under nitrogen for $24 \mathrm{~h}$, unless otherwise noted. ${ }^{b}$ Monomer conversion was determined by ${ }^{1} \mathrm{H}$ NMR spectroscopy. ${ }^{d}$ Molecular weight and polydispersity index $\left(M_{\mathrm{w}} / M_{\mathrm{n}}\right)$ were determined by SEC analysis calibrated to polystyrene standards. ${ }^{d} \mathrm{~V} / \mathrm{V}=1 / 1$.

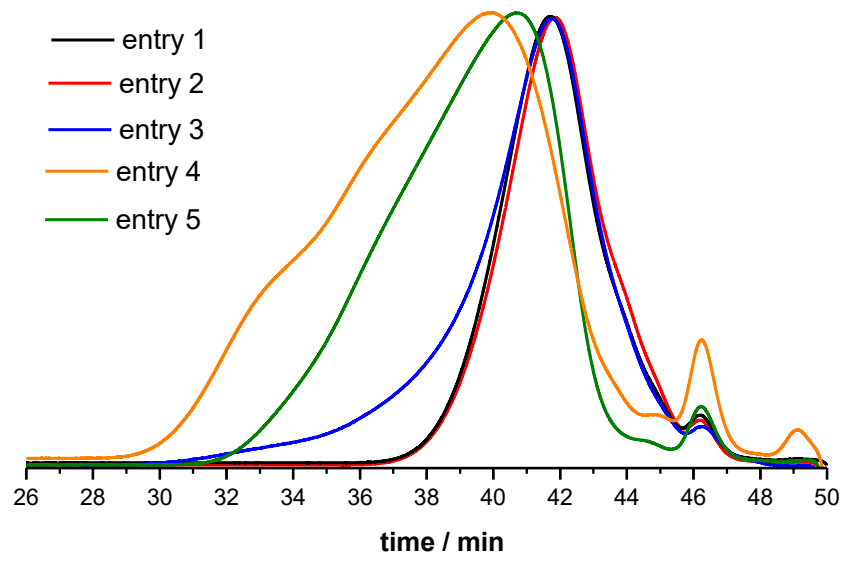

Figure S19. SEC traces of the polymerization of macrocyclic monomer 11 in different solvents. 
Table S7. Effect of different CTAs on the polymerization of macrocyclic monomer 11.
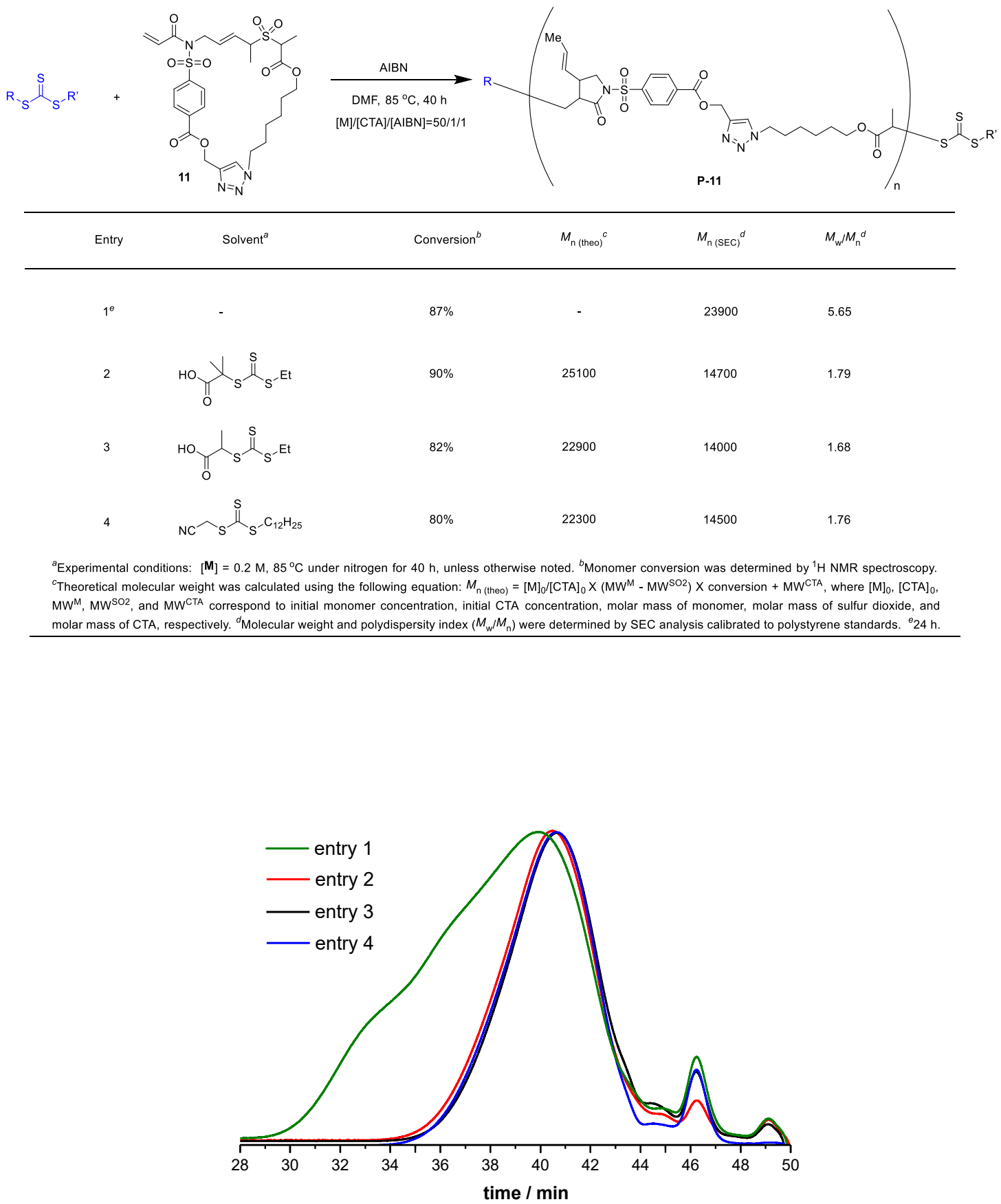

Figure S20. SEC traces of the polymerization of macrocyclic monomer $\mathbf{1 1}$ in the presence of different CTAs. 
Table S8. Effect of different CTA/AIBN ratio on the polymerization of macrocyclic monomer.
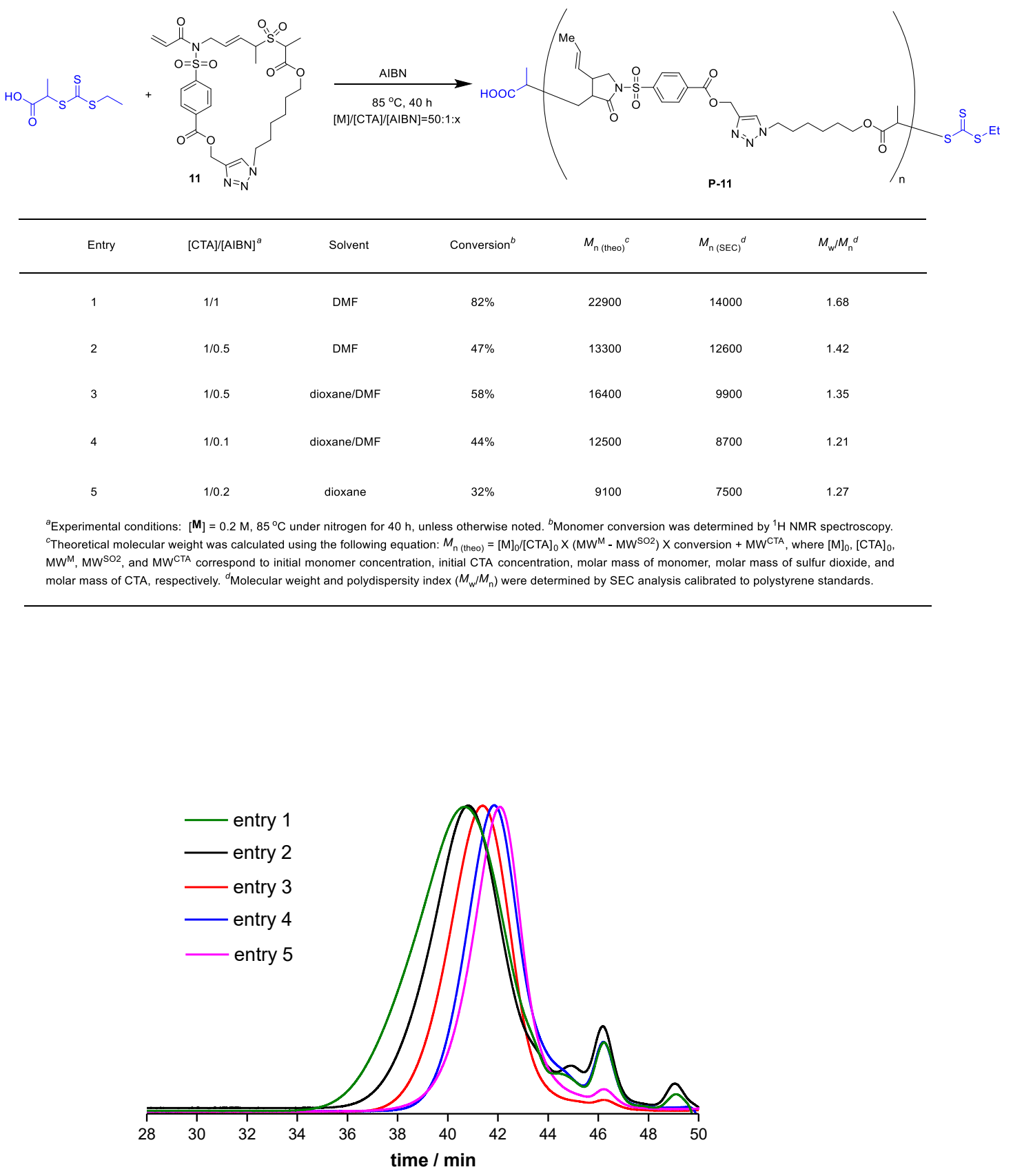

Figure S21. SEC traces of the polymerization of macrocyclic monomer $\mathbf{1 1}$ at different monomer/CTA ratios and different solvents. 
Table S9. Different monomer/CTA ratio on the polymerization of macrocyclic monomer 11.

\begin{tabular}{|c|c|c|c|c|c|c|}
\hline Entry & {$[\mathrm{M}] /[\mathrm{CTA}]^{a}$} & Time & Conversion $^{b}$ & $M_{n \text { (thoo) }}{ }^{c}$ & $M_{\mathrm{n}(\mathrm{SEC})^{d}}$ & $M_{\mathrm{w}} \mathcal{M}_{\mathrm{n}}{ }^{d}$ \\
\hline 1 & 10/1 & $40 \mathrm{~h}$ & $62 \%$ & 3700 & 4100 & 1.20 \\
\hline 2 & $25 / 1$ & $40 \mathrm{~h}$ & $45 \%$ & 6500 & 6500 & 1.24 \\
\hline 3 & 50/1 & $40 \mathrm{~h}$ & $44 \%$ & 12500 & 8700 & 1.21 \\
\hline 4 & 100/1 & $45 \mathrm{~h}$ & $47 \%$ & 26500 & 10000 & 1.23 \\
\hline 5 & 200/1 & $45 \mathrm{~h}$ & $48 \%$ & 53800 & 11000 & 1.35 \\
\hline
\end{tabular}

${ }^{a}$ Experimental conditions: $\left[{ }^{M}\right]=0.1 \mathrm{M}, 85^{\circ} \mathrm{C}$ under nitrogen, unless otherwise noted. ${ }^{b}$ Monomer conversion was determined by ${ }^{1} \mathrm{H}$ NMR spectroscopy. ${ }^{\circ}$ Theoretical molecular weight was calculated using the following equation: $M_{n}$ (theo) $=[M]_{0} /[C T A]_{0} \times\left(M^{M}-M W^{S 02}\right) \times$ conversion $+M W^{C T A}$, where $[M]_{0},[C T A]_{0}, M^{M}, M W^{S 02}$, and $M^{C T A}$ correspond to initial monomer concentration, initial $C T A$ concentration, molar mass of monomer, molar mass of sulfur dioxide, and molar mass of CTA, respectively. ${ }^{d}$ Molecular weight and polydispersity index $\left(M_{\mathrm{w}} / M_{n}\right)$ were determined by SEC analysis calibrated to polystyrene standards.

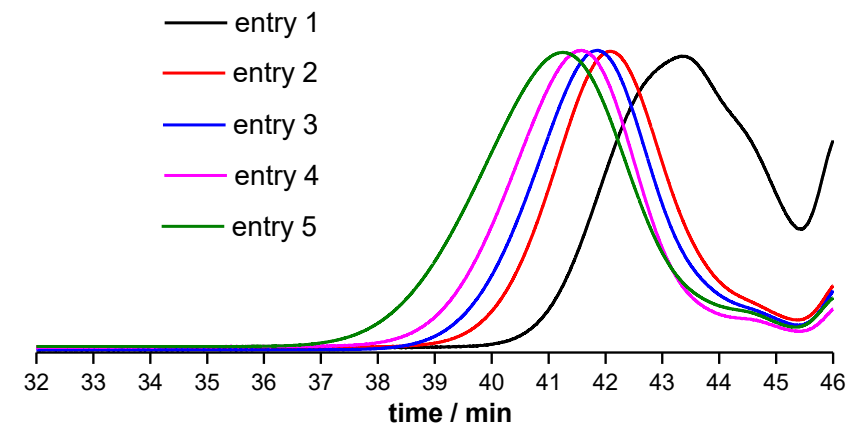

Figure S22. SEC traces of the polymerization of macrocyclic monomer $\mathbf{1 1}$ at different monomer/CTA ratios. 
Table S10. Different monomer/CTA ratio on the polymerization of macrocyclic monomer 12.

\begin{tabular}{|c|c|c|c|c|c|c|}
\hline Entry & {$[\mathrm{M}][\mathrm{CTA}]^{a}$} & Time & Conversion $^{b}$ & $M_{n \text { (theo) }}{ }^{c}$ & $M_{n(S E C))^{d}}$ & $M_{w} M_{n}{ }^{d}$ \\
\hline 1 & 50/1 & $40 \mathrm{~h}$ & $46 \%$ & 12700 & 9000 & 1.23 \\
\hline 2 & 100/1 & $45 \mathrm{~h}$ & $46 \%$ & 25300 & 11200 & 1.32 \\
\hline
\end{tabular}

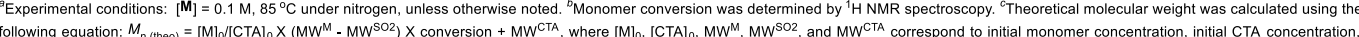
molar mass of monomer, molar mass of sulfur dioxide, and molar mass of CTA, respectively. ${ }^{d}$ Molecular weight and polydispersity index $\left(M_{w} / M_{n}\right)$ were determined by SEC analysis calibrated to polystyrene standards.

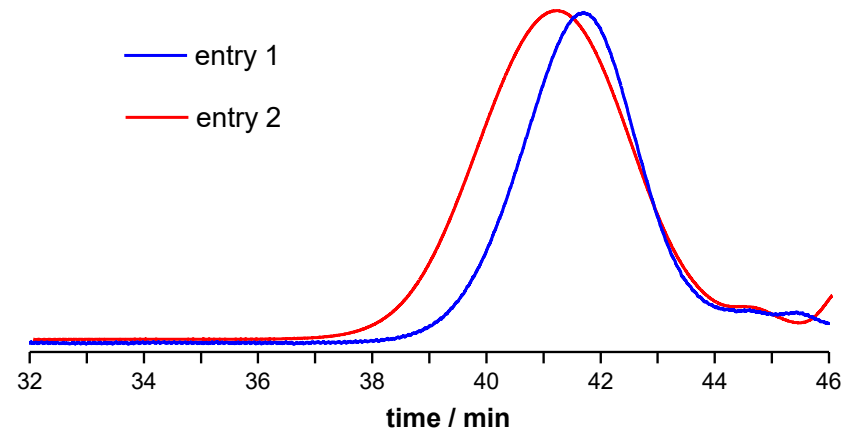

Figure S23. SEC traces of the polymerization of macrocyclic monomer $\mathbf{1 2}$ at different monomer/CTA ratios. 
Table S11. Different monomer/CTA ratio on the polymerization of macrocyclic monomer 13.

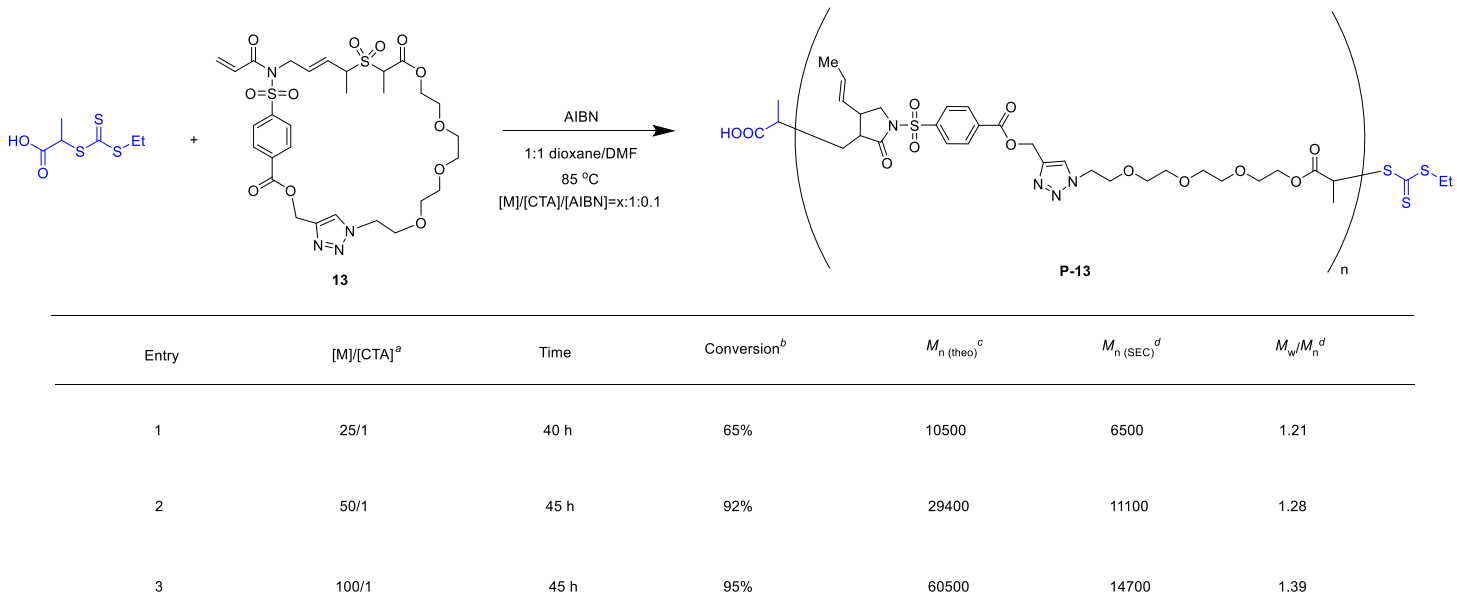

${ }^{a}$ Experimental conditions: $[\mathrm{M}]=0.1 \mathrm{M}, 85^{\circ} \mathrm{C}$ under nitrogen, unless otherwise noted. ${ }^{b}$ Monomer conversion was determined by ${ }^{1} \mathrm{H}$ NMR spectroscopy. ${ }^{C}$ Theoretical molecular weight was calculated using the

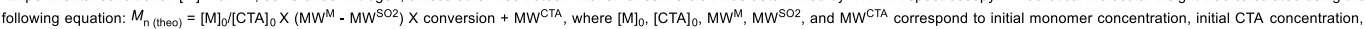
molar mass of monomer, molar mass of sulfur dioxide, and molar mass of CTA, respectively. ${ }^{d}$ Molecular weight and polydispersity index $\left(M_{w} / M_{n}\right)$ were determined by SEC analysis calibrated to polystyrene standards.

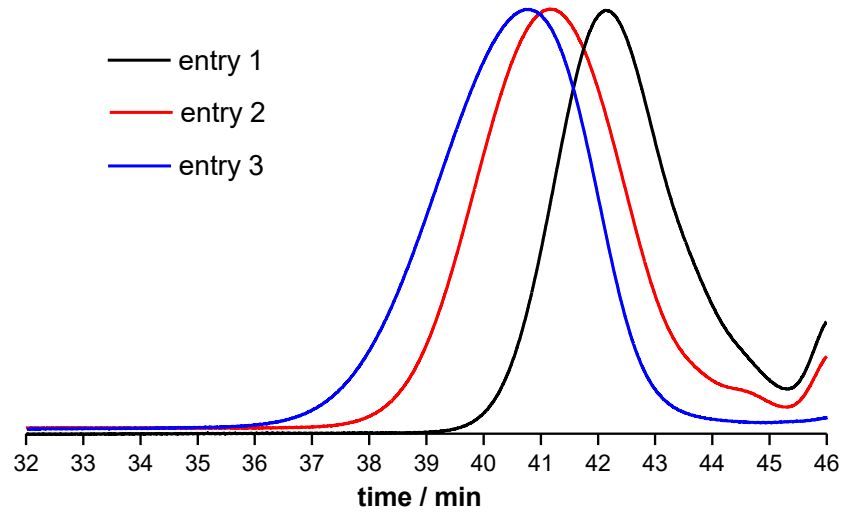

Figure S24. SEC traces of the polymerization of macrocyclic monomer 13 at different monomer/CTA ratios. 
Table S12. Yield of polymers.

\begin{tabular}{|c|c|c|c|c|c|c|}
\hline Entry & Position & Monomers & $M_{\mathrm{n}(\mathrm{SEC})}$ & $M_{\mathrm{w}} / M_{\mathrm{n}}$ & Conversion & Yield \\
\hline 1 & Table S4, entry 4 & 3 & 6800 & 1.16 & $87 \%$ & $77 \%$ \\
\hline 2 & Scheme S7 & 10 & 17600 & 2.09 & $>95 \%$ & $86 \%$ \\
\hline 3 & Table S9, entry 4 & 11 & 10000 & 1.23 & $47 \%$ & $42 \%$ \\
\hline 4 & Table S10, entry 2 & 12 & 11200 & 1.32 & $46 \%$ & $42 \%$ \\
\hline 5 & Table S11, entry 1 & 13 & 6500 & 1.21 & $65 \%$ & $54 \%$ \\
\hline
\end{tabular}


Compare $M_{\mathrm{n}(\mathrm{SEC})}, \quad M_{\mathrm{n}(\mathrm{NMR})}$ and $M_{\mathrm{n}(\mathrm{LS})}$ of polymer P-11.

SEC analysis: $M_{\mathrm{n}(\mathrm{SEC})}=9800$

NMR analysis: $M_{\mathrm{n}(\mathrm{NMR})}=20900$

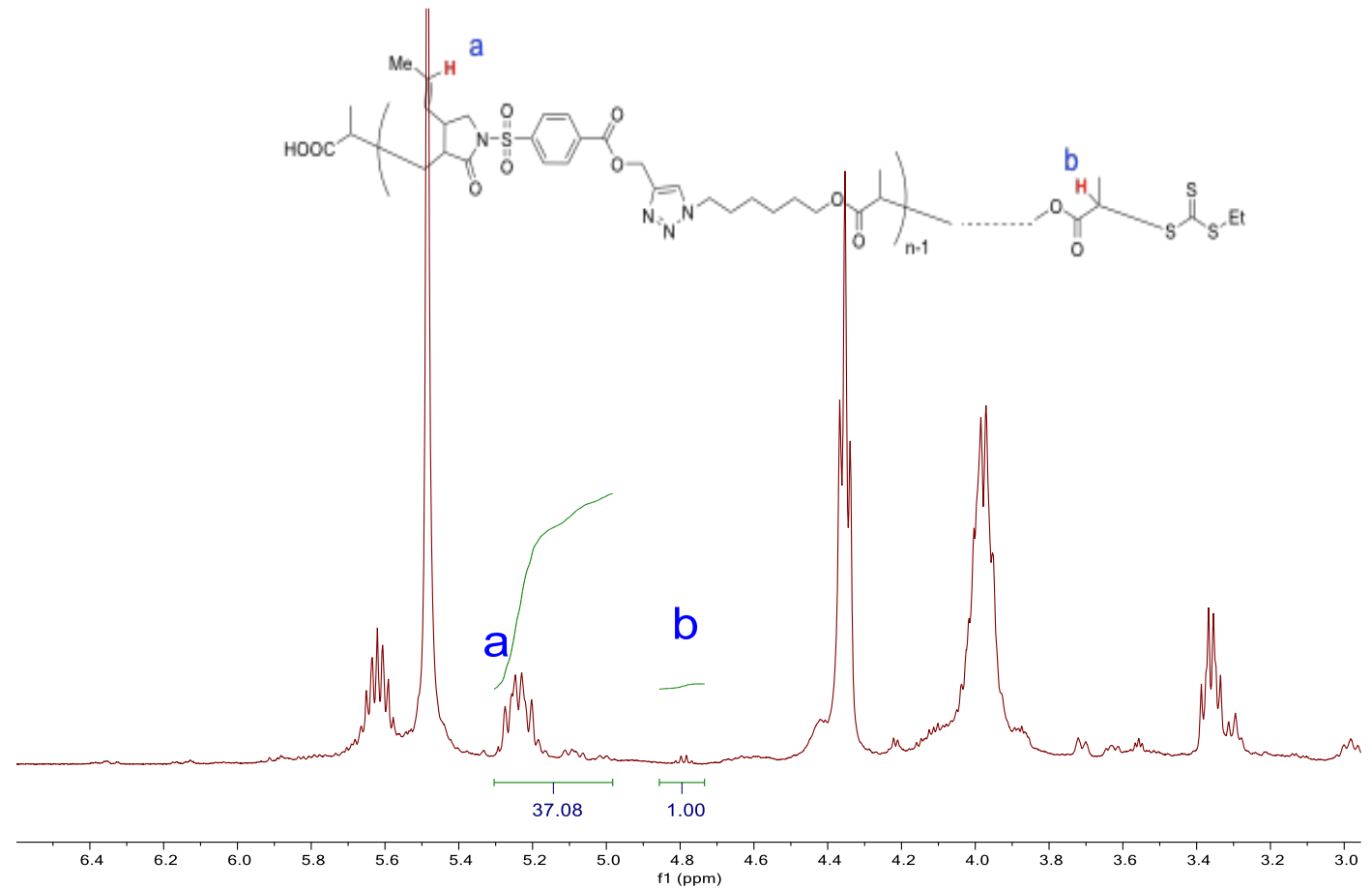

Light scattering analysis: $M_{\mathrm{n}(\mathrm{LS})}=18500$

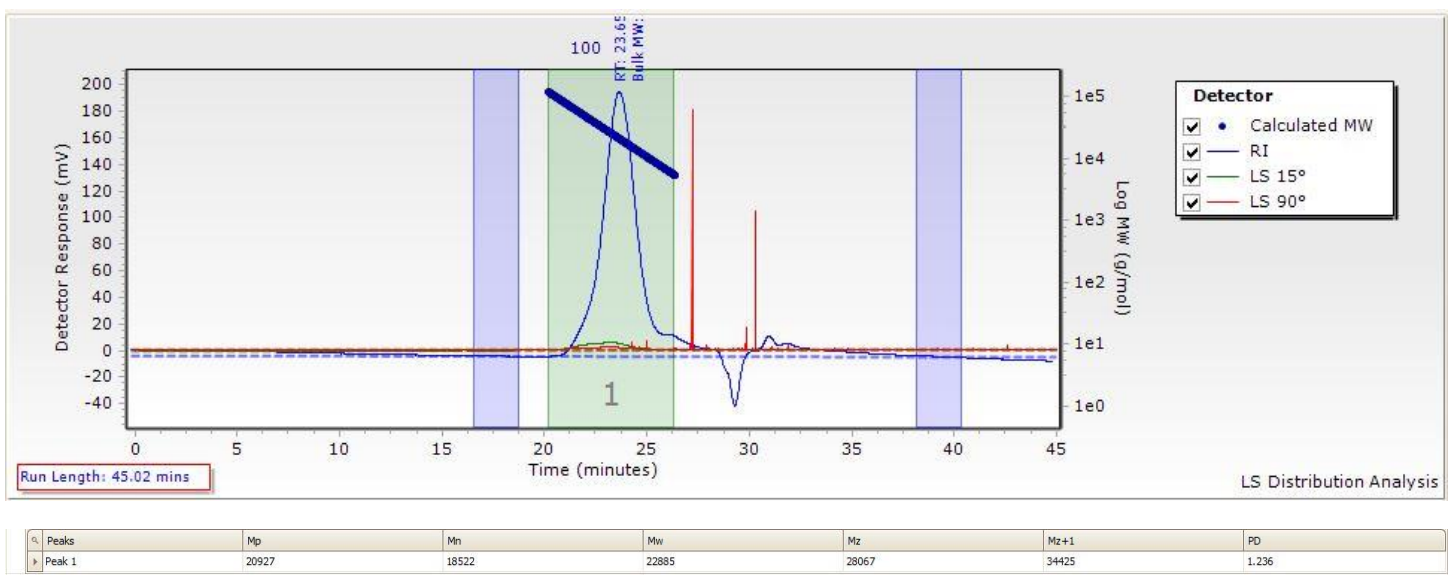

Figure S25. Compare $M_{\mathrm{n}(\mathrm{SEC})}, M_{\mathrm{n}(\mathrm{NMR})}$ and $M_{\mathrm{n}(\mathrm{LS})}$ of polymer P-11. 
Kinetic study on the polymerization of macrocyclic monomer 11.

(a)

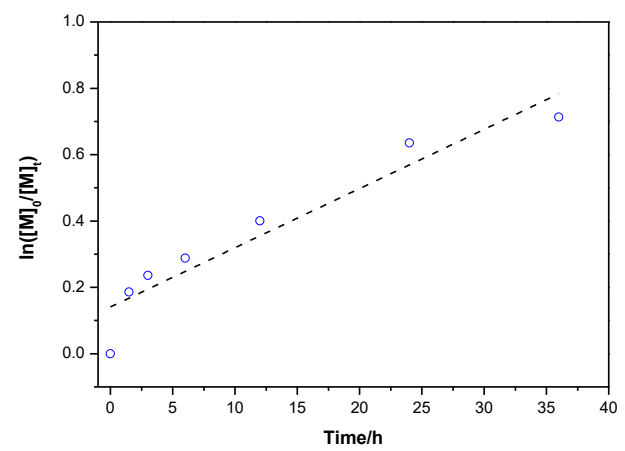

(b)

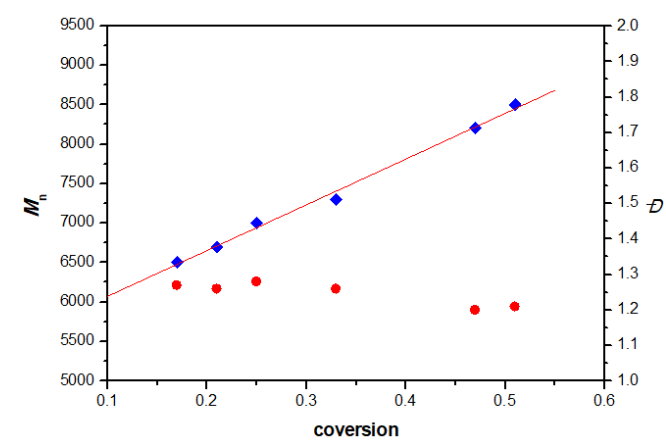

(c)

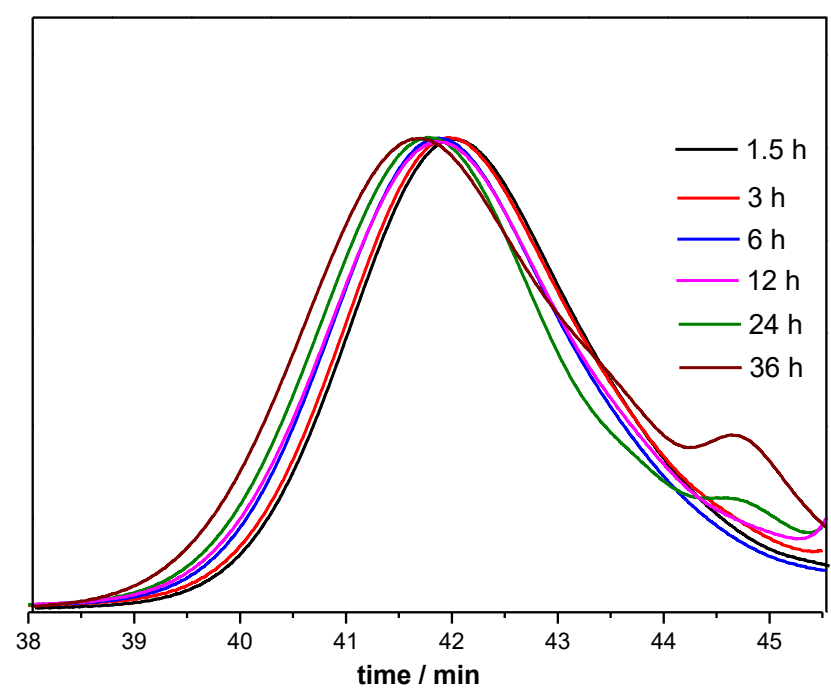

Figure S26. Kinetic study on the polymerization of macrocyclic monomer 11. (a) A linear relationship between $\ln \left([\mathrm{M}]_{0} /[\mathrm{M}]_{\mathrm{t}}\right)$ and reaction time was observed during the intermediate stage of polymerization. The high reaction rate at the very early stage of the polymerization was likely attributed to the high concentration of the monomer. At monomer conversion higher than $50 \%$, the rate of polymerization notably decreased. This phenomenon was also observed in our previous work. ${ }^{6}$ (b) Plot of $M_{\mathrm{n}}$ and $Ð$ versus monomer conversion. (c) SEC traces of different times.

The reaction kinetics of RCROP is complex: (1) unlike classic controlled radical polymerization of (meth)acrylates in which the monomer addition directly generates the propagating radical, in the RCROP process the addition of the monomer to the propagating radical generates intermediate radical species which undergo a cascade of multiple reactions before regenerating the propagating radical. (2) A side reaction was identified that takes place simultaneously to the desired cascade polymerization, in which a minor fraction of the monomers was found to undergo elimination of the acryloyl group from the monomer, forming a non-polymerizable byproduct (see Figure S27 and S28). The combined effects of complex reaction mechanism and the presence of side reaction caused the slow evolution of the molecular weight. We would like to note that due to the mechanistic 
complexity, non-productive side reactions have also been identified in other cascade polymerization systems. $^{7}$

In addition, the structural differences between the polymers prepared in this work and the polystyrene standard used to calibrate the SEC could cause additional errors in molecular weight estimation by SEC. For example, higher $M_{\mathrm{n}}(\mathrm{SEC})$ was observed when using a SEC equipped with a light scattering detector (see Figure 25). 


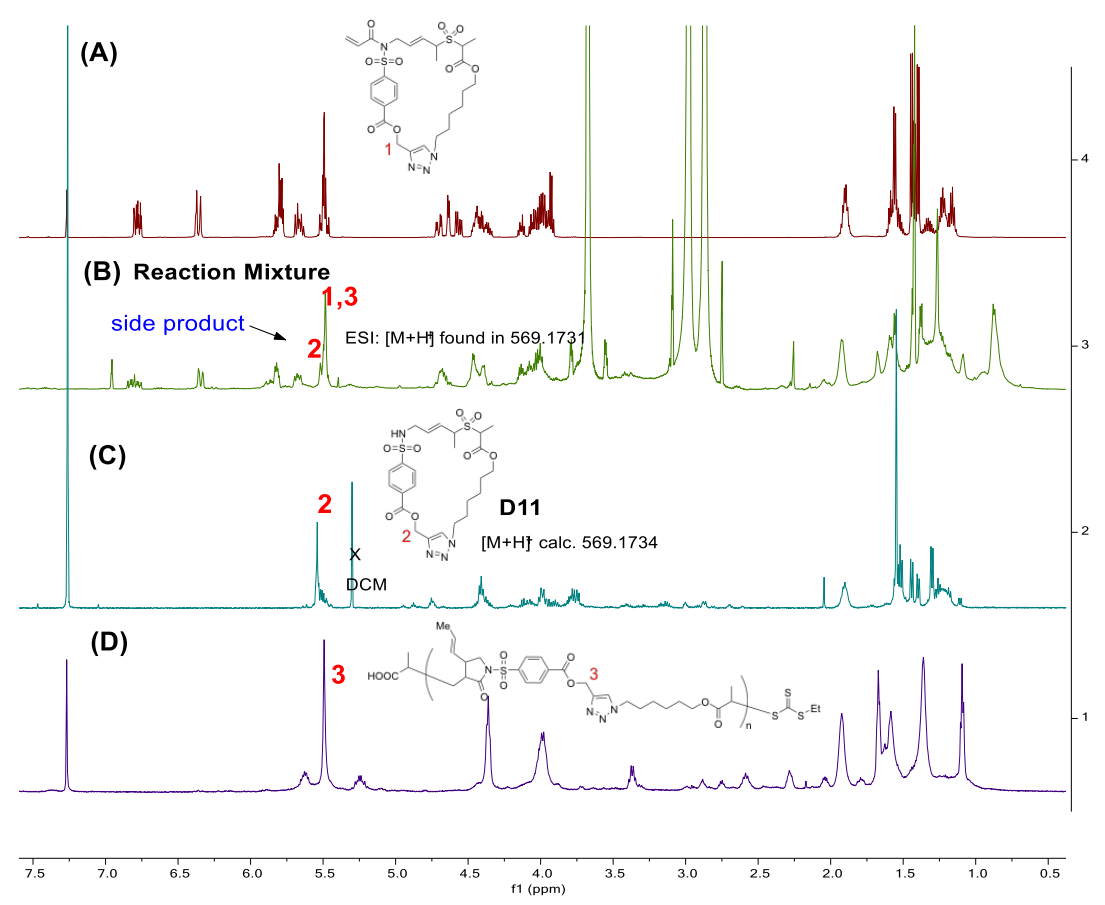

Figure S27. NMR determination of side reaction for the polymerization of $\mathbf{1 1 .}$

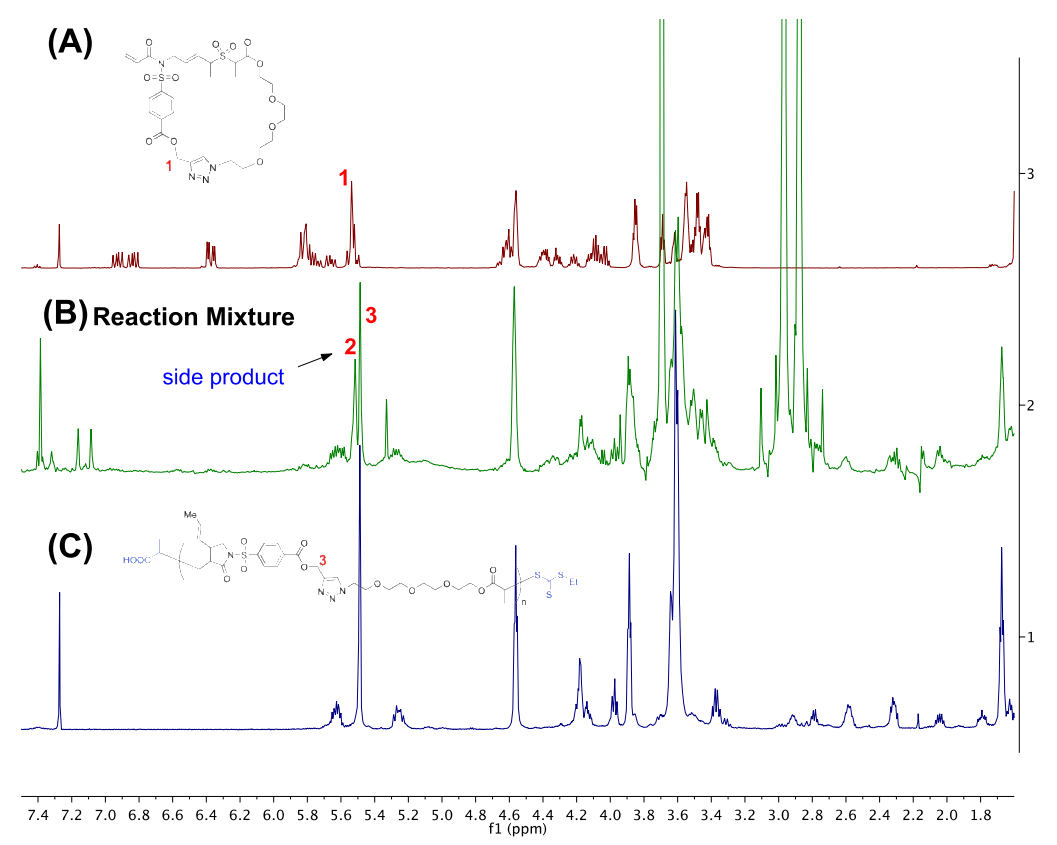

Figure S28. NMR determination of side reaction for the polymerization of $\mathbf{1 3}$.

A side reaction at high monomer conversion was observed leading to elimination of acryloyl group from the monomer. Because the byproduct does not have a polymerizable group, it cannot be incorporated into the polymer. NMR analysis of the purified polymer confirmed the absence of the signal of this byproduct. The de-acryloyl product was also reported under the 2,2,6,6-tetramethylpiperidin-1-oxyl radical (TEMPO) condition. ${ }^{8}$ 
(A) Radical ring-closing/ring-opening cascade polymerization of macrocyclic monomer $\mathbf{1 0}$

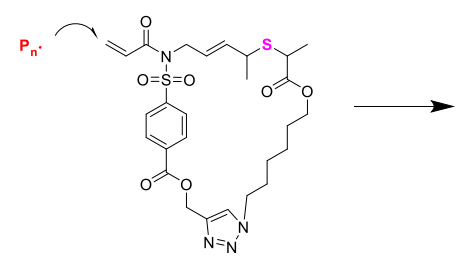

M
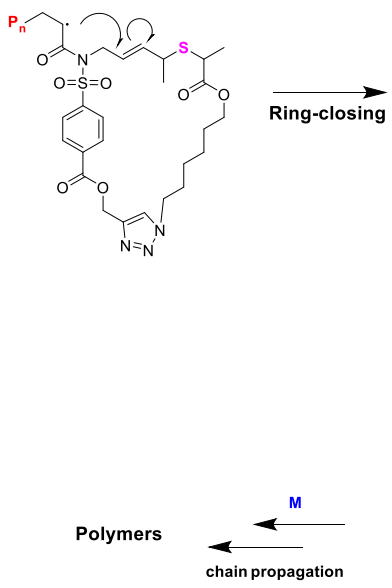
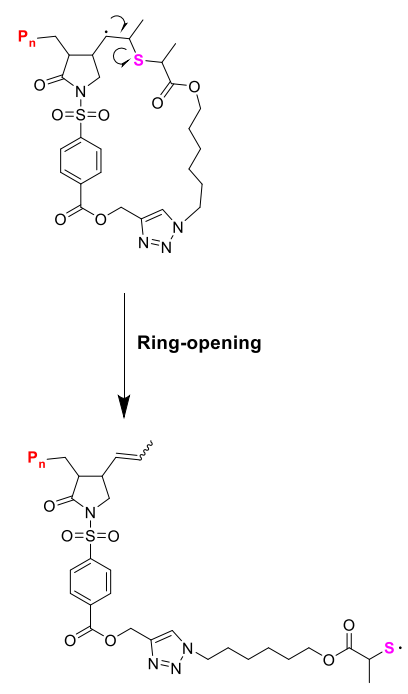

$P_{n}$.

(B) Radical ring-closing/ring-opening cascade polymerization of macrocyclic monomer $\mathbf{1 1}$

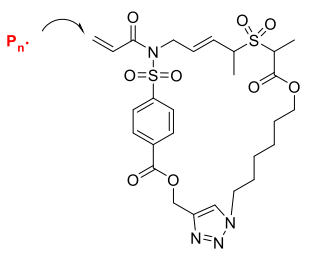

M

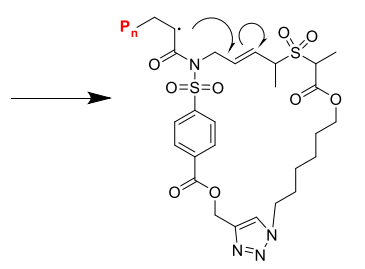

$\overrightarrow{\text { Ring-closing }}$
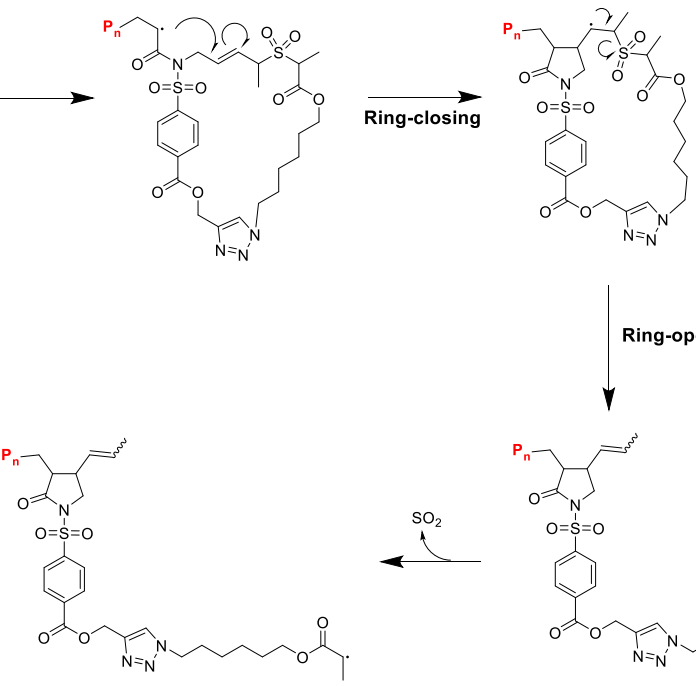

$P_{n}$
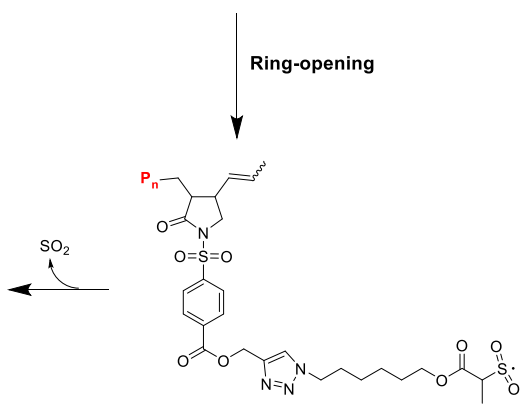

Figure S29. Proposed mechanism for the ring-closing/ring-opening polymerization. 


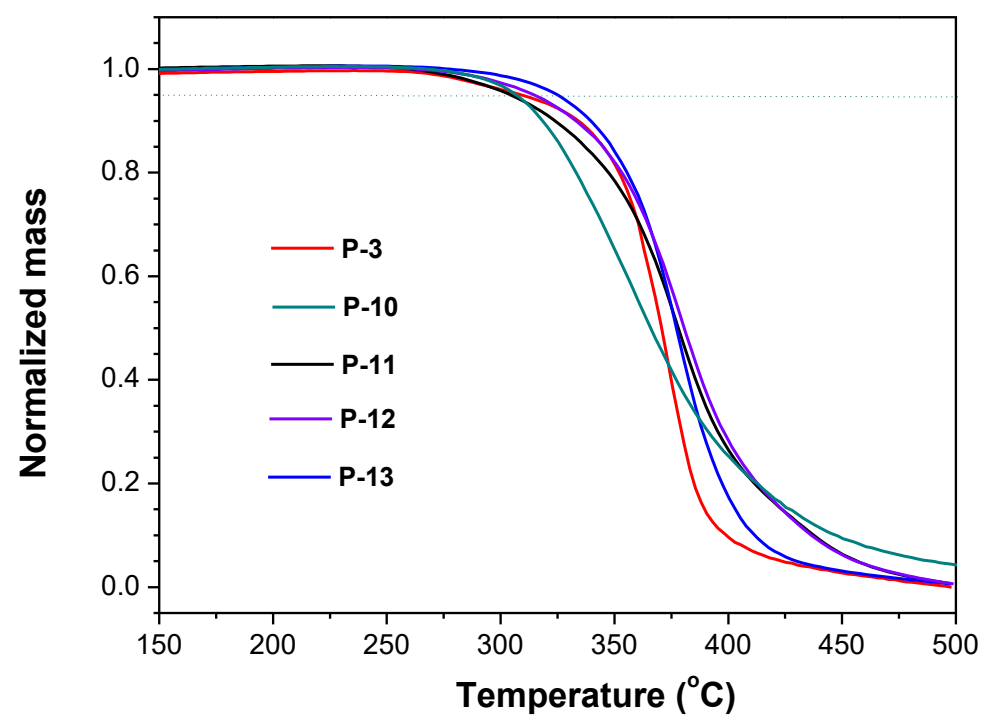

Figure S30. TGA thermograms of different polymers recorded under argon at a heating rate of $10{ }^{\circ} \mathrm{C} / \mathrm{min}$.

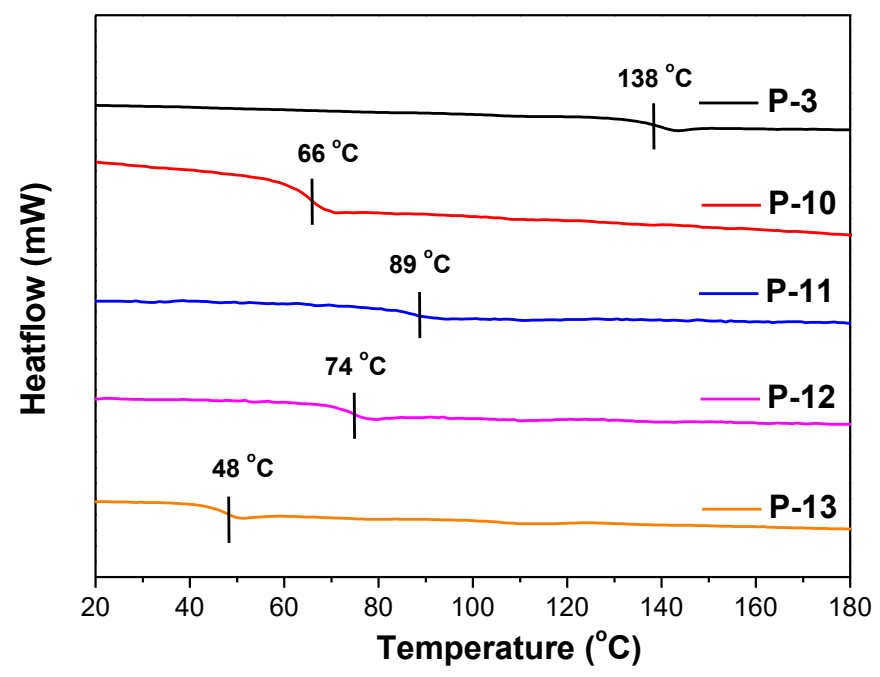

Figure S31. DSC thermograms of different polymers recorded under argon during the second heating cycle at a heating rate of $10^{\circ} \mathrm{C} / \mathrm{min}$. 


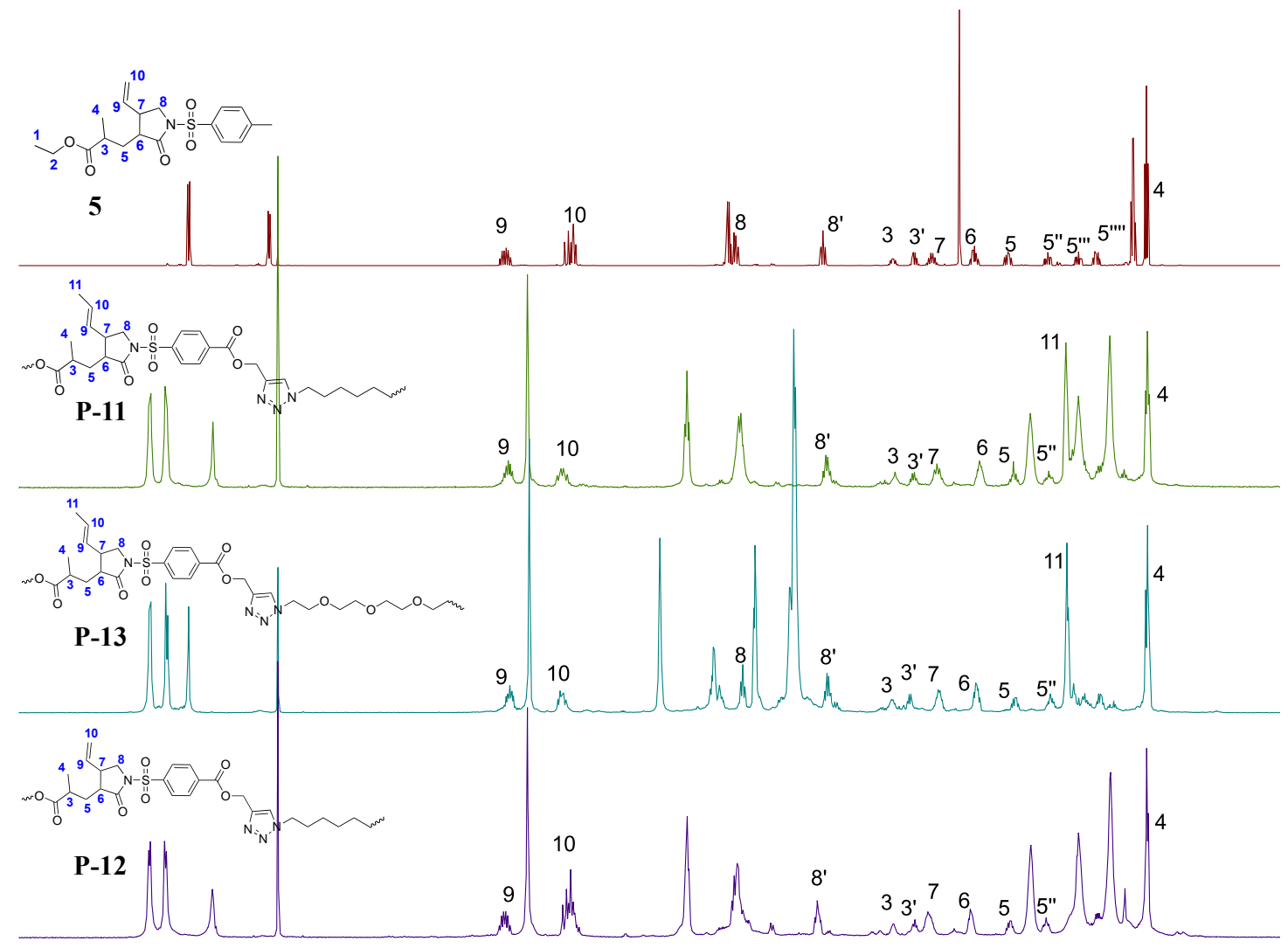

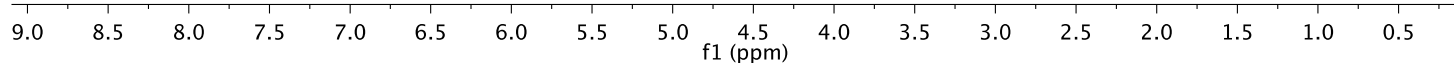

Figure S32. ${ }^{1} \mathrm{H}$ NMR analysis of model product 5 and polymers P-11 to P-13. 


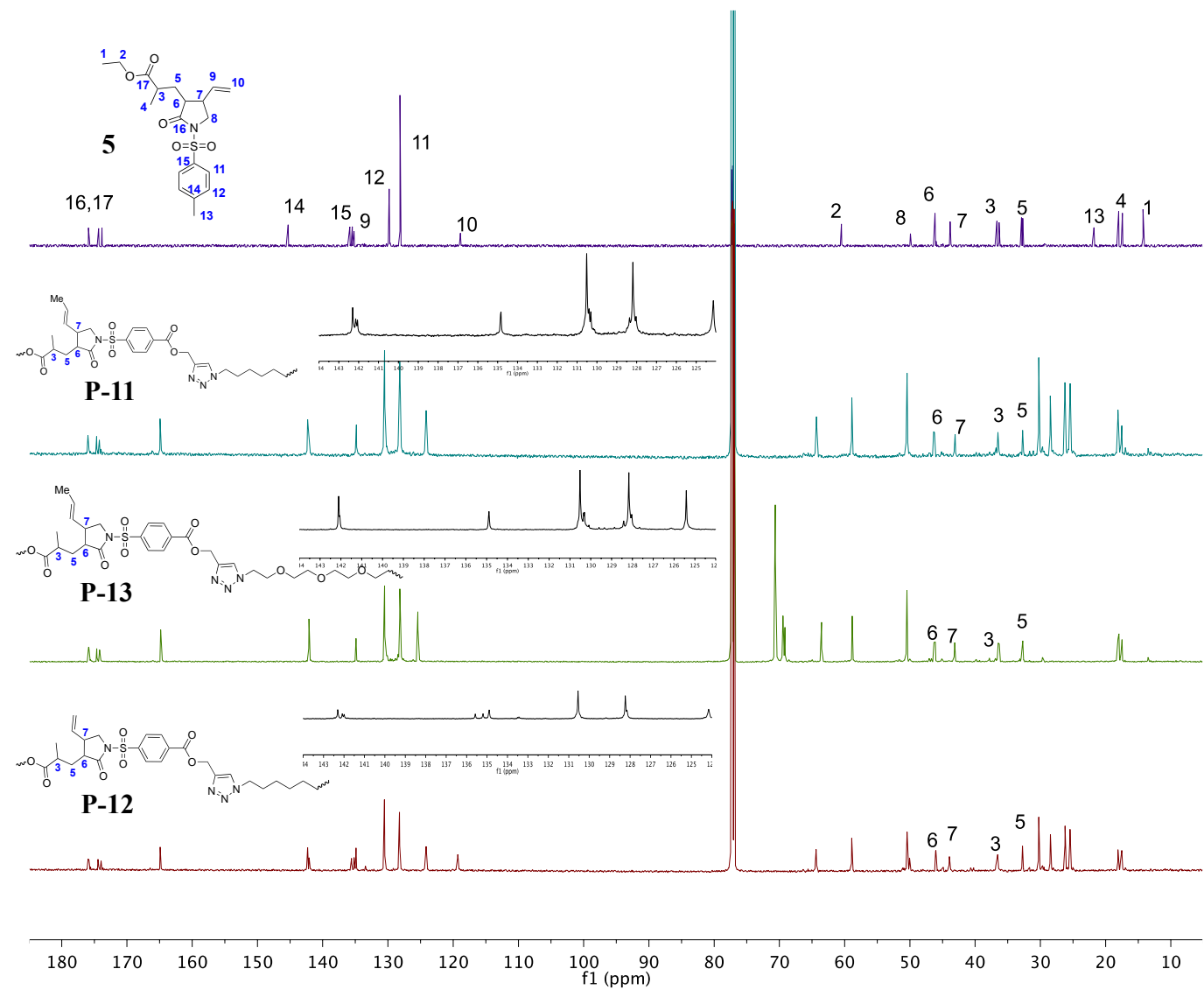

Figure S33. ${ }^{13} \mathrm{C}$ NMR analysis of the model product 5 and polymers P-11 to P-13. 


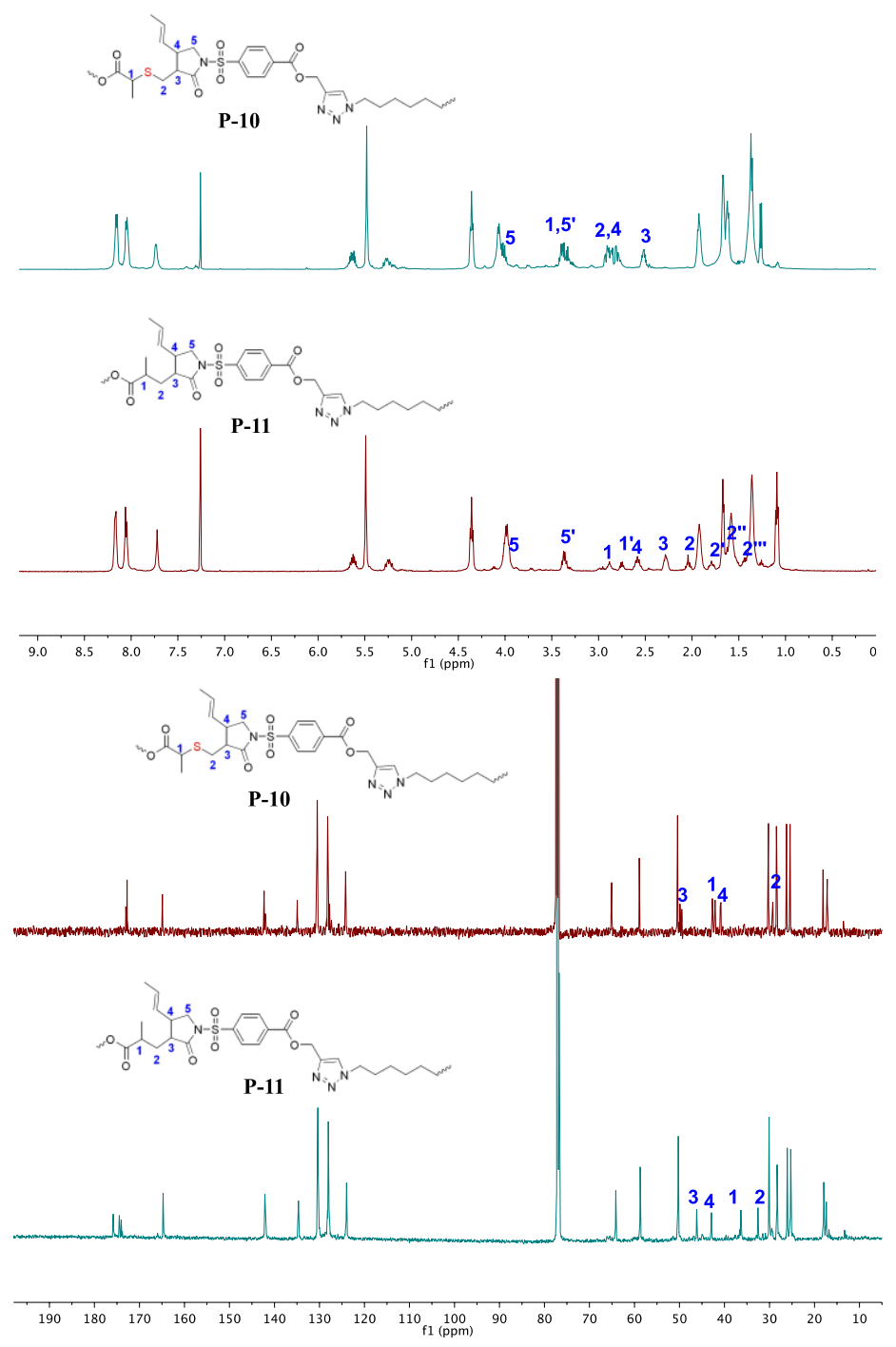

Figure S34. NMR analysis of polymer P-10 and its comparison with the spectra of P-11.

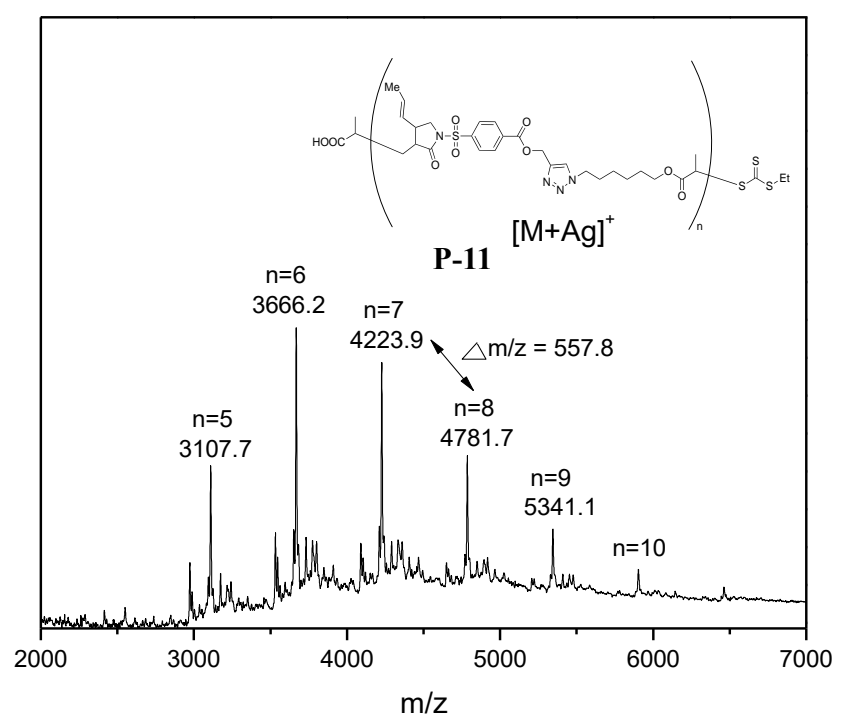

Figure S35. MALDI-TOF analysis of polymer P-11. 
Scheme S10. Post-modification of P-12 by metathesis.

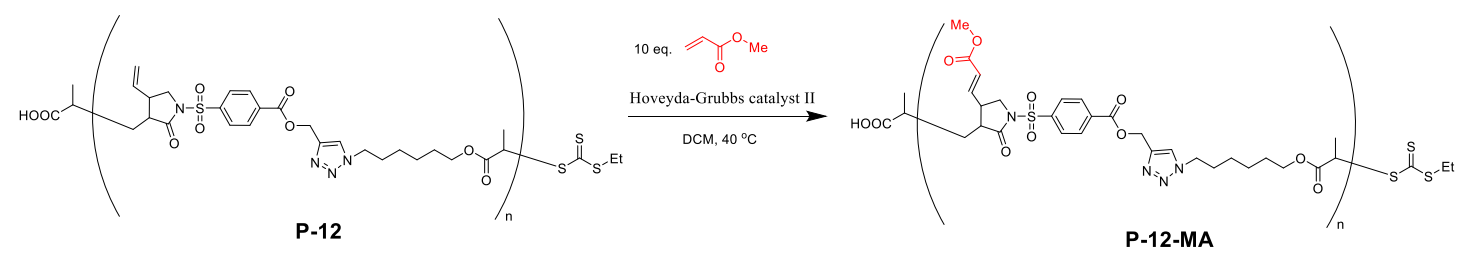

Polymer P-12-MA was prepared following a procedure slightly modified from literature. ${ }^{9}$ A $10 \mathrm{~mL}$ Schlenk vial was charged with polymer P-10 $\left(9.0 \mathrm{mg}\right.$, about $16.5 \mu$ mol repeat unites, SEC: $M_{\mathrm{n}}=$ 9.0k, $\oslash=1.23)$, methyl acrylate $(14.9 \mathrm{uL}, 165 \mu \mathrm{mol})$ and $0.5 \mathrm{~mL}$ degas DCM, followed by HoveydaGrubbs catalyst $2 \mathrm{nd}(1 \mathrm{mg})$. The vial was sealed and oxygen was removed via one freeze-pumpthaw cycle, backfilled with nitrogen, then heated at $40{ }^{\circ} \mathrm{C}$ for $10 \mathrm{~h}$. The reaction was quenched with a few drops of ethyl vinyl ether, precipitated in methanol/ethyl ether (V/V: 1/5), yielding the copolymer P-12-MA (SEC: $M_{\mathrm{n}}=9.2 \mathrm{k}, D=1.26$ ).

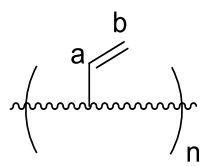

P-12

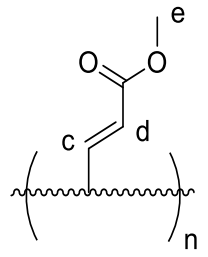

P-12-MA
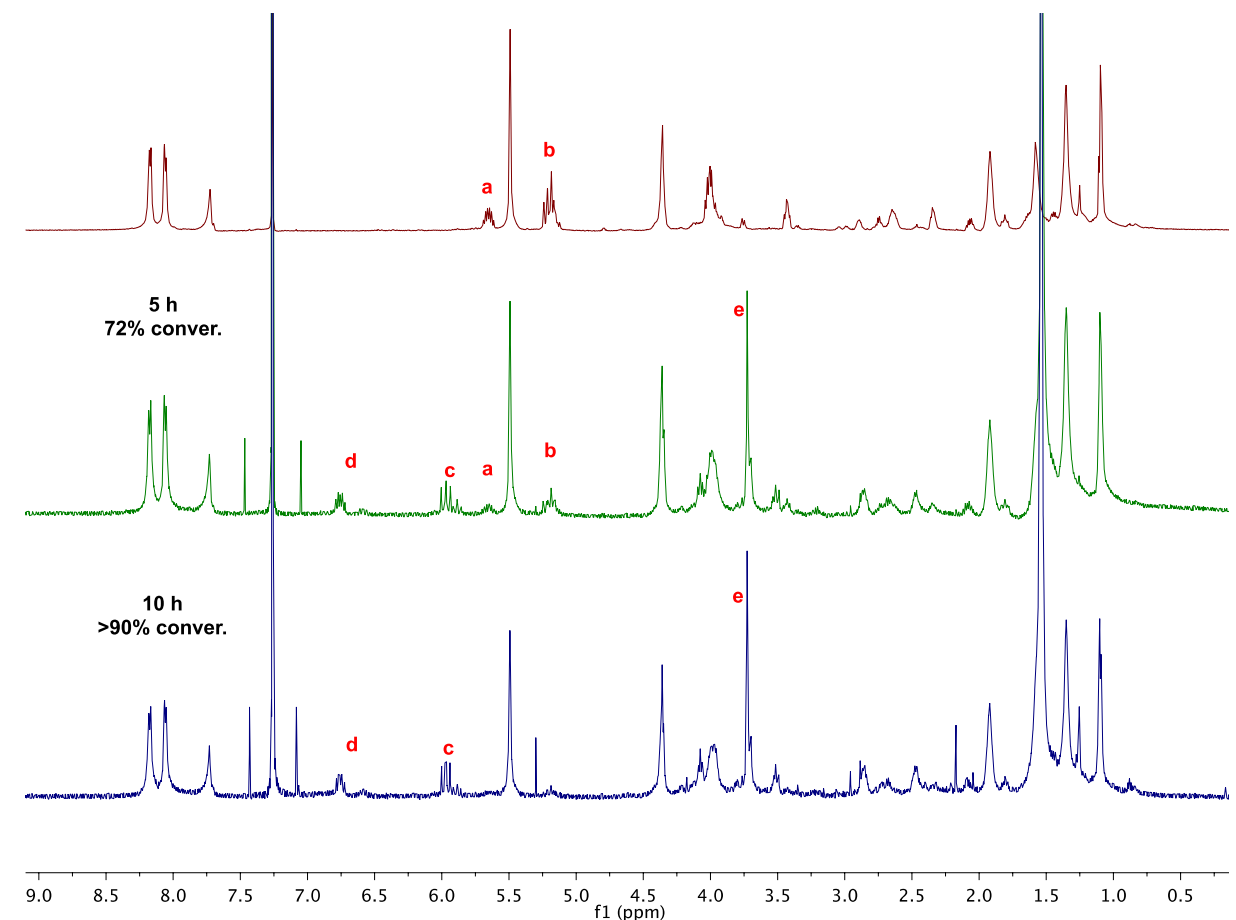

Figure S36. ${ }^{1} \mathrm{H}$ NMR analysis of post-modification of P-12. 


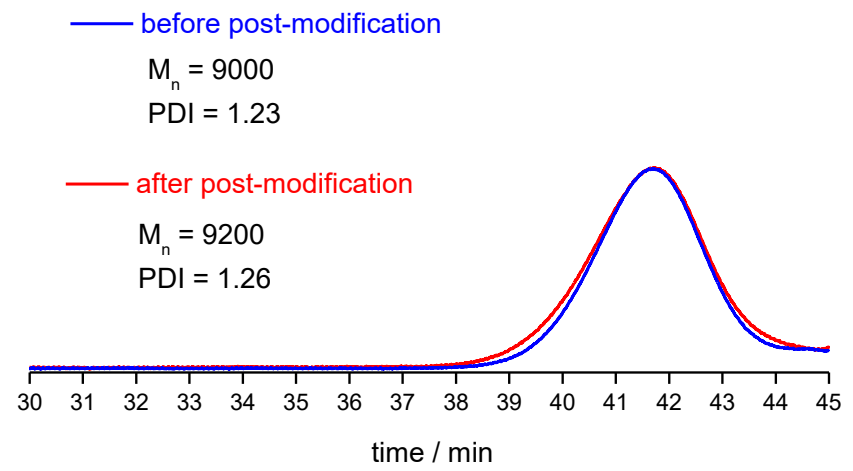

Figure S37. SEC trace of post-modification of P-12. The molecular weight obtained from GPC indicated a negligible increase in molecular weight compared to the nonfunctionalized precursor, a result seen previously in the literature. ${ }^{9,10}$ 
Scheme S11. Synthesis of diblock copolymer.

\section{Synthesis of diblock copolymer P-11-b-P-13.}
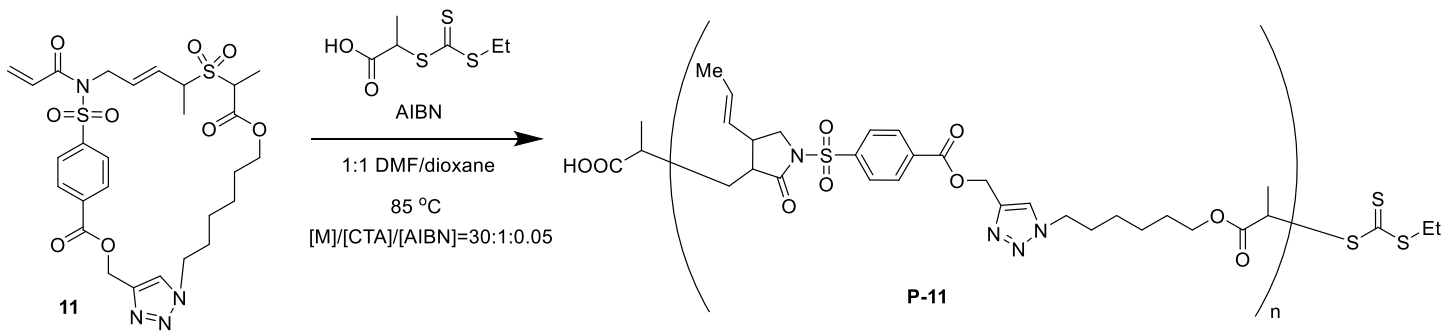

Follow the polymerization general procedure, a $10 \mathrm{~mL}$ Schlenk vial was charged with macrocyclic monomer $11(50.0 \mathrm{mg}, 80.2 \mu \mathrm{mol})$, followed by CTA2 (16 mM in DMF, $167.3 \mu \mathrm{L}, 2.68 \mu \mathrm{mol})$, AIBN ( $8 \mathrm{mM}$ in DMF, $16.7 \mu \mathrm{L}, 0.134 \mu \mathrm{mol})$, DMF $(217 \mu \mathrm{L})$ and dioxane $(401 \mu \mathrm{L})$. The vial was sealed and the solution was deoxygenated via three freeze-pump-thaw cycles, backfilled with nitrogen, then heated at $85^{\circ} \mathrm{C}$ for $15 \mathrm{~h}$. The vial was cooled by ice bath and open to air to stop the polymerization. The reaction mixture was precipitated twice with methanol/ethyl ether (V/V: 1/8), yielding the polymer $\left(M_{\mathrm{n}}=7100, D=1.21\right)$.

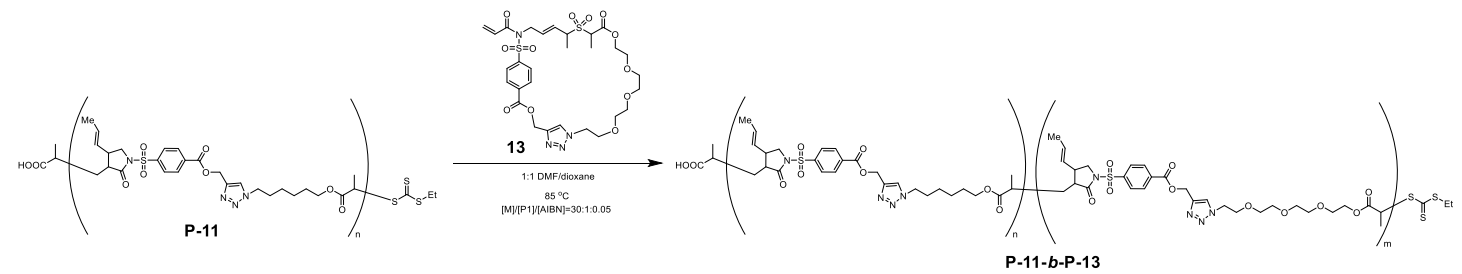

A $10 \mathrm{~mL}$ Schlenk vial was charged with macrocyclic monomer $13(56.2 \mathrm{mg}, 80.4 \mu \mathrm{mol})$, macroinitiator P-11 $(2.68 \mu \mathrm{mol})$, AIBN (16 mM in DMF, $16.7 \mu \mathrm{L}, 0.134 \mu \mathrm{mol})$, DMF (385.3 $\mu \mathrm{L})$ and dioxane $(402 \mu \mathrm{L})$. The vial was sealed and the solution was deoxygenated via three freezepump-thaw cycles, backfilled with nitrogen, then heated at $85{ }^{\circ} \mathrm{C}$ for $17 \mathrm{~h}$. The vial was cooled by ice bath and open to air to stop the polymerization. The reaction mixture was precipitated three times with methanol/ethyl ether (V/V: $1 / 8)$, yielding the polymer $\left(M_{\mathrm{n}}=10100, \oslash=1.35\right)$.

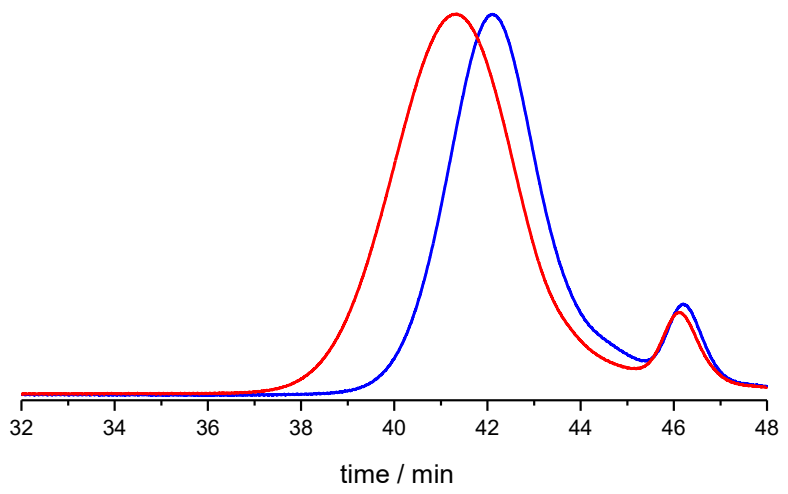

Figure S38. SEC traces of the block copolymerization. 
Scheme S12. Methanolysis of polymer P-13.
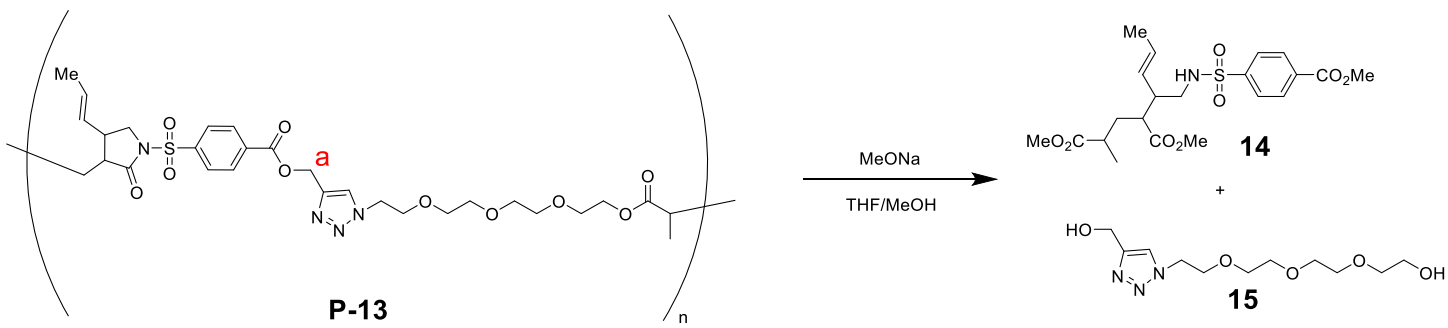

P-13 (5 mg) was added to a $4 \mathrm{~mL}$ vial equipped with a stir bar, dissolved in THF $(0.5 \mathrm{~mL})$ and stirred at room temperature. A solution of sodium methoxide $(10 \mu \mathrm{L}$ of a $25 \mathrm{wt} \%$ solution in methanol) was added and the vial is capped. At the given time, the reaction is stopped by the addition of a $1 \mathrm{M}$ aqueous hydrochloric acid $(0.1 \mathrm{~mL})$ and dried with $\mathrm{Na}_{2} \mathrm{SO}_{4}$ and concentrated in vacuo. The sample was analyzed with NMR, SEC and mass spectral.
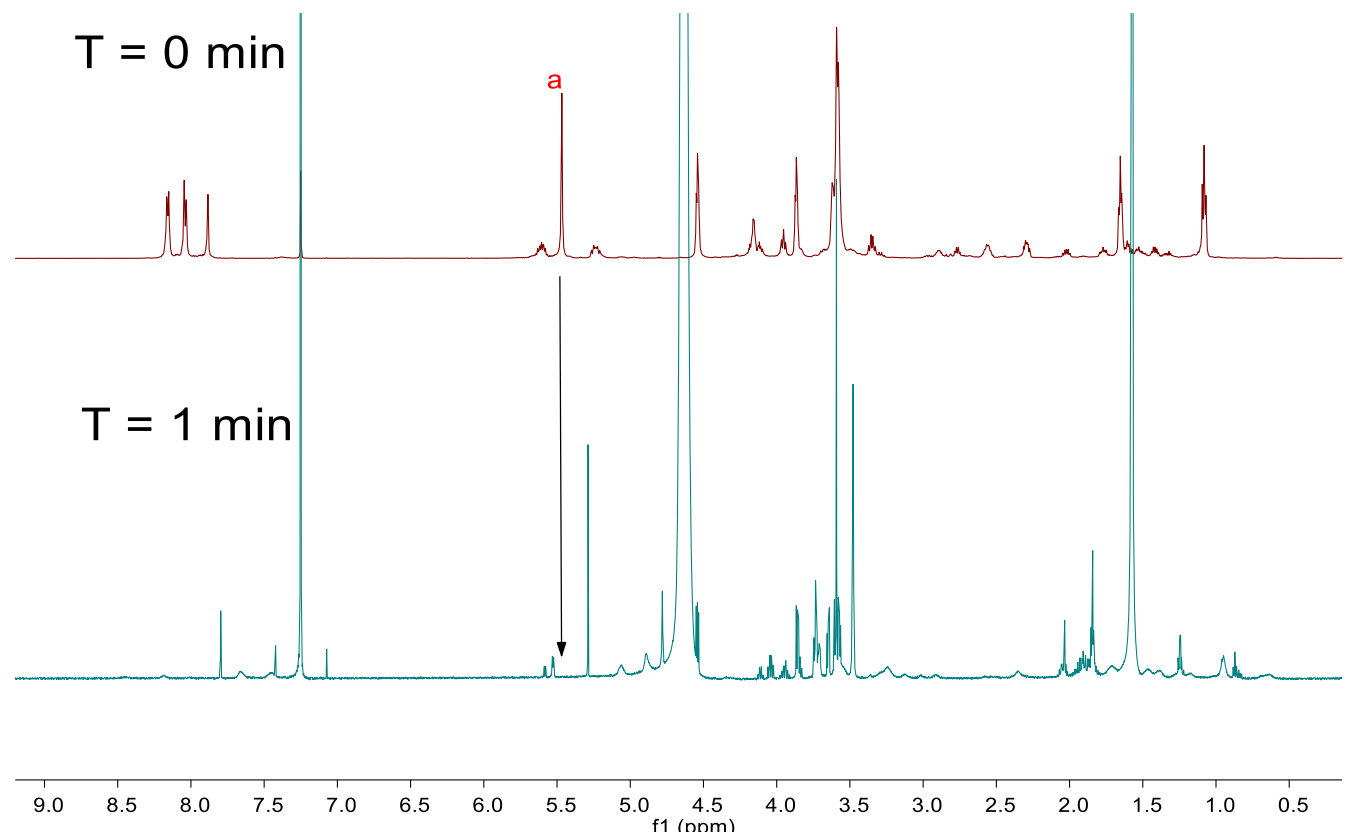

Figure S39. ${ }^{1} \mathrm{H}$ NMR of methanolysis of $\mathbf{P - 1 3}$. $\mathrm{T}=0 \mathrm{~min}$ : all peaks in the starting polymer were broad; $\mathrm{T}=1 \mathrm{~min}$ : the ester peak $a$ of the polymer backbone disappeared (indicated by the black arrow) and most peaks were sharpened, indicating the small hydrolysis fragments. 


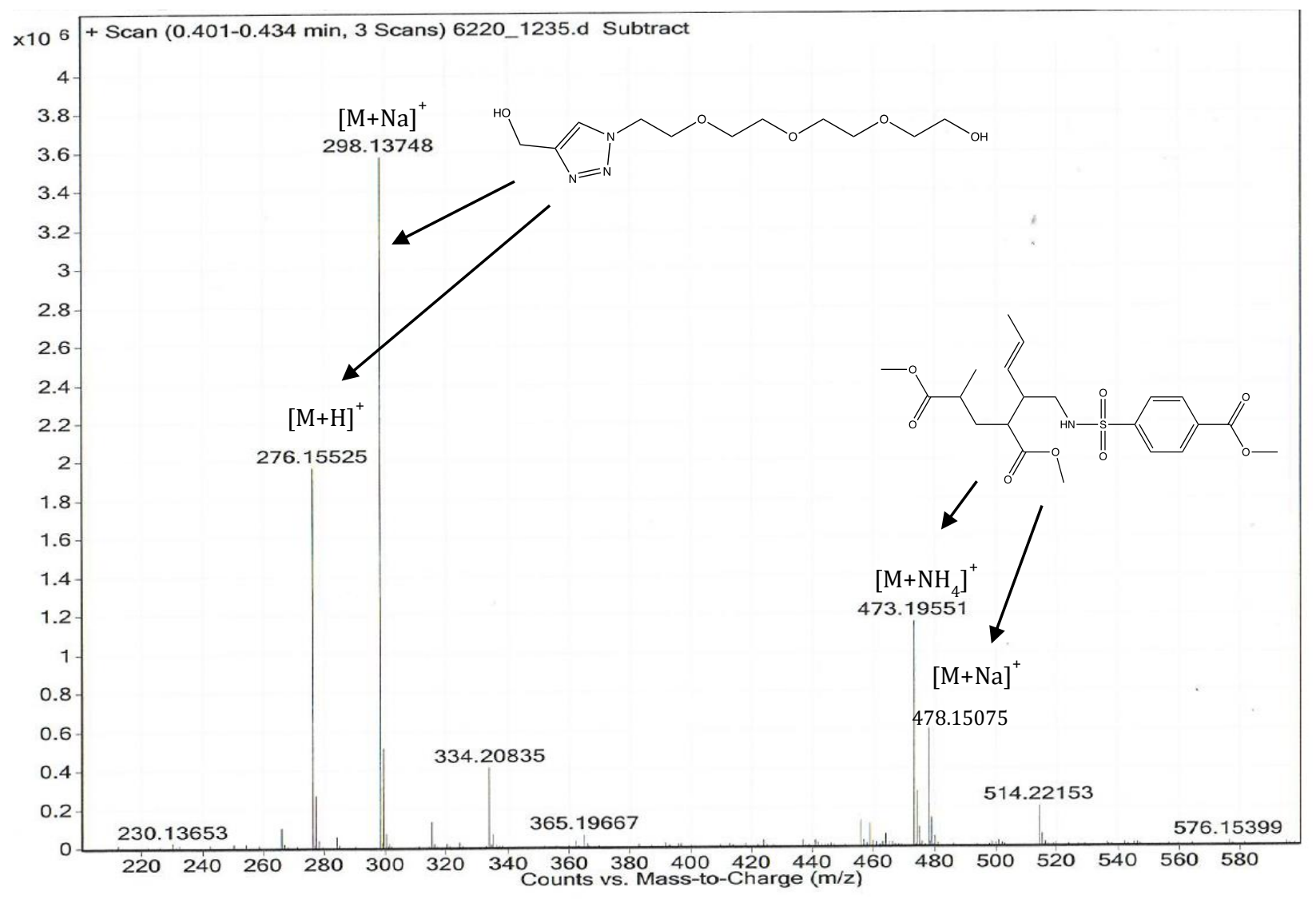

Figure S40. Mass spectrometry analysis of the methanolysis of P-13. 
Scheme S13. Derivatization and isolation of degradation product.

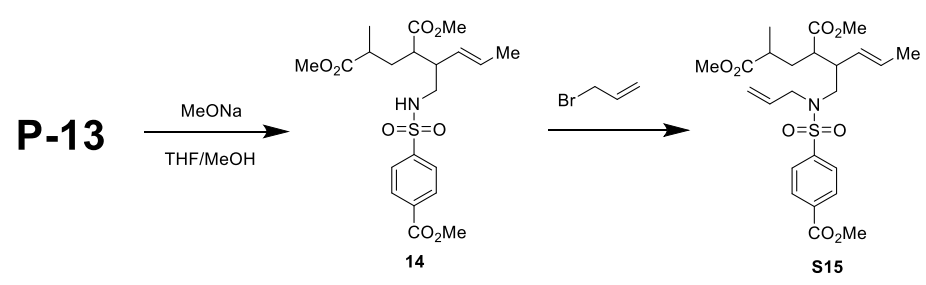

P-13 (25 mg) was added to a $4 \mathrm{~mL}$ vial equipped with a stir bar, dissolved in THF $(0.5 \mathrm{~mL})$ and stirred at room temperature. A solution of sodium methoxide $(50 \mu \mathrm{L}$ of a $25 \mathrm{wt} \%$ solution in methanol) was added and the vial is capped. After $1 \mathrm{~min}$, allyl bromide $(100 \mu \mathrm{L})$ was added and the reaction was continue stirred for $1 \mathrm{~h}$. The reaction mixture was directly purified by column chromatography to afford a colorless oil $\mathbf{S 1 5}$ (73\% yield). ${ }^{1} \mathrm{H}$ NMR $\left(600 \mathrm{MHz}, \mathrm{CDCl}_{3}\right): \delta 8.15$ (d, $J$ $=8.2 \mathrm{~Hz}, 2 \mathrm{H}), 7.89-7.83(\mathrm{~m}, 2 \mathrm{H}), 5.51-5.33(\mathrm{~m}, 2 \mathrm{H}), 5.16-5.01(\mathrm{~m}, 3 \mathrm{H}), 3.96(\mathrm{~s}, 3 \mathrm{H}), 3.89-3.74$ (m, 2H), 3.71-3.62 (m, 6H), 3.19-3.05 (m, 2H), $2.61(\mathrm{dp}, J=14.1,7.2 \mathrm{~Hz}, 1 \mathrm{H}), 2.46-2.29(\mathrm{~m}, 2 \mathrm{H})$, 2.01-1.80 (m, 1H), 1.66-1.52 (m, 4H), $1.14(\mathrm{~d}, J=6.8 \mathrm{~Hz}, 3 \mathrm{H}) ;{ }^{13} \mathrm{C}$ NMR $\left(150 \mathrm{MHz}, \mathrm{CDCl}_{3}\right): \delta$ 176.5, 174.9, 165.8, 144.4, 133.8, 132.0, 130.4, 130.1, 129.0, 127.4, 120.0, 52.8, 51.8, 50.6, 49.3, $46.2,45.7,44.2,37.8,33.7,33.2,29.9,18.6,18.2,16.6$; HRMS $(\mathrm{m} / \mathrm{z})[\mathrm{M}+\mathrm{H}]^{+}$calc'd for $\mathrm{C}_{24} \mathrm{H}_{34} \mathrm{NO}_{8} \mathrm{~S}, 496.2000$, found 496.2002 .

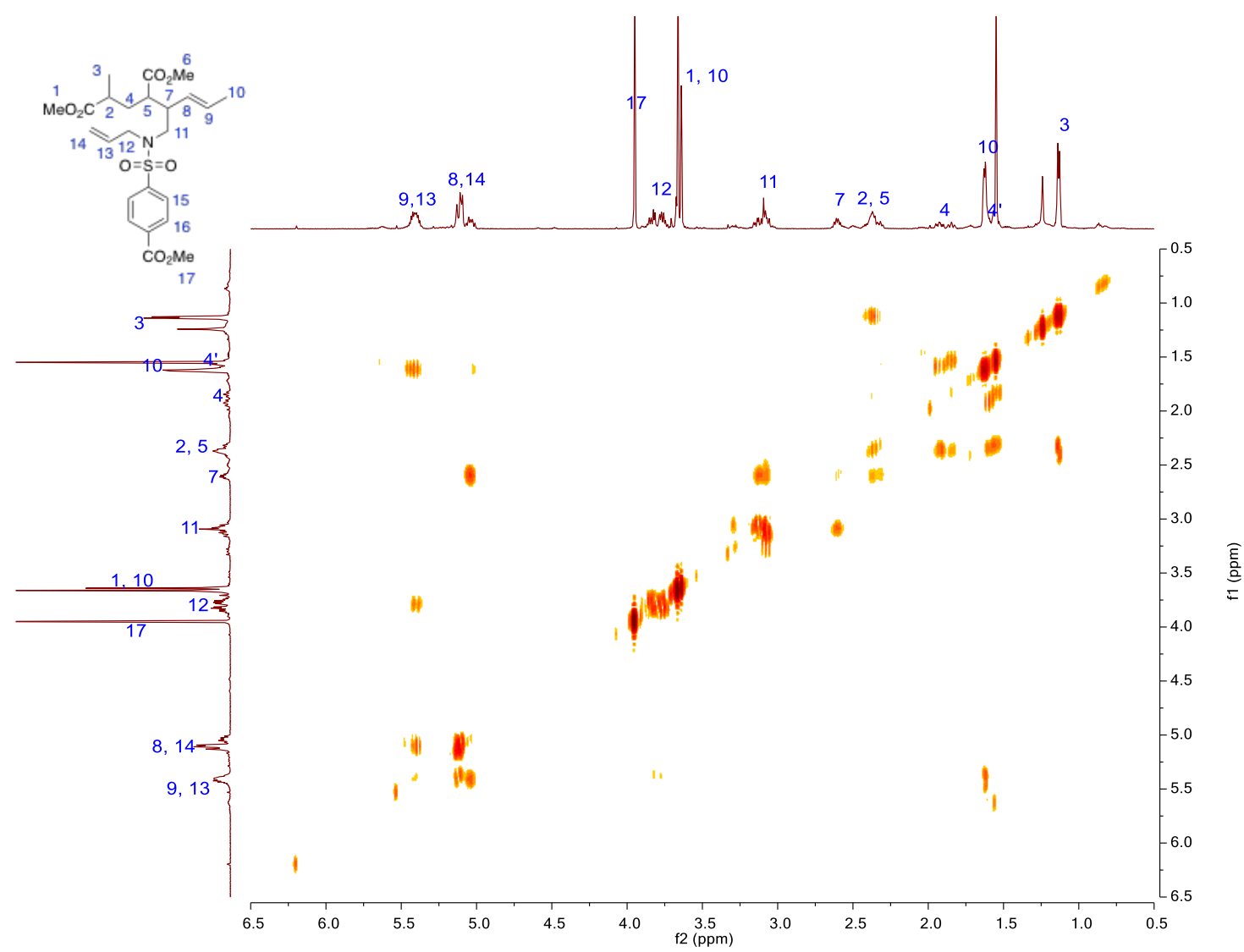

Figure S41. COSY spectra of degradation product. 


\section{References}

(1) Skey, J.; O'Reilly, R. K. Chem. Commun. 2008, 44, 4183-4185.

(2) Gaussian 09, Revision A.02, M. J. Frisch, G. W. Trucks, H. B. Schlegel, G. E. Scuseria, M. A. Robb, J. R. Cheeseman, G. Scalmani, V. Barone, B. Mennucci, G. A. Petersson, H. Nakatsuji, M. Caricato, X. Li, H. P. Hratchian, A. F. Izmaylov, J. Bloino, G. Zheng, J. L. Sonnenberg, M. Hada, M. Ehara, K. Toyota, R. Fukuda, J. Hasegawa, M. Ishida, T. Nakajima, Y. Honda, O. Kitao, H. Nakai, T. Vreven, J. A. Montgomery, Jr., J. E. Peralta, F. Ogliaro, M. Bearpark, J. J. Heyd, E. Brothers, K. N. Kudin, V. N. Staroverov, R. Kobayashi, J. Normand, K. Raghavachari, A. Rendell, J. C. Burant, S. S. Iyengar, J. Tomasi, M. Cossi, N. Rega, J. M. Millam, M. Klene, J. E. Knox, J. B. Cross, V. Bakken, C. Adamo, J. Jaramillo, R. Gomperts, R. E. Stratmann, O. Yazyev, A. J. Austin, R. Cammi, C. Pomelli, J. W. Ochterski, R. L. Martin, K. Morokuma, V. G. Zakrzewski, G. A. Voth, P. Salvador, J. J. Dannenberg, S. Dapprich, A. D. Daniels, O. Farkas, J. B. Foresman, J. V. Ortiz, J. Cioslowski, and D. J. Fox, Gaussian, Inc., Wallingford CT, 2009.

(3) Serpier, F.; Flamme, B.; Brayer, J.-L.; Folléas, B.; Darses, S. Org. Lett. 2015, 17, 1720-1723.

(4) Wilkinson, B. L.; Bornaghi, L. F.; Houston, T. A.; Innocenti, A.; Supuran, C. T.; Poulsen, S.-A. J. Med. Chem. 2006, 49, 6539-6548.

(5) Chouhan, G.; James, K. Org. Lett. 2011, 13, 2754-2757.

(6) Huang, H.; Sun, B.; Huang, Y.; Niu, J. J. Am. Chem. Soc. 2018, 140, 10402-10406.

(7) Gutekunst, W.; Hawker, C. J. J. Am. Chem. Soc. 2015, 137, 8038-8041.

(8) Ni, Z.; Huang, X.; Pan, Y. Org. Lett. 2016, 18, 2612-2615.

(9) Sinclair, F.; Chen, L.; Greenland, B.; Shaver, M. Macromolecules 2016, 49, 6826-6834.

(10) Fournier, L.; Robert, C.; Pourchet, S.; Gonzalez, A.; Williams, L.; Prunet, J.; Thomas, C. M. Polym. Chem. 2016, 7, 3700-3704. 
NMR spectra

NMR of 1

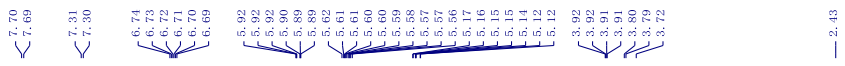<smiles>C=CCN(CC=CC(C)=O)S(=O)(=O)c1ccc(C)cc1</smiles>

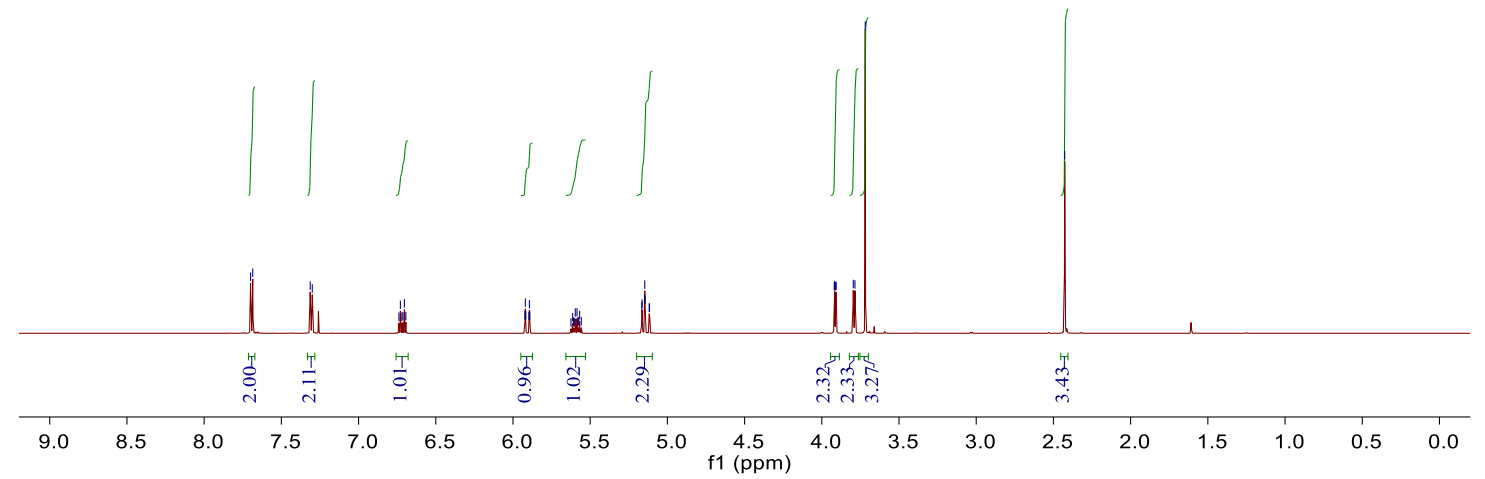

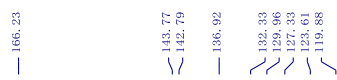
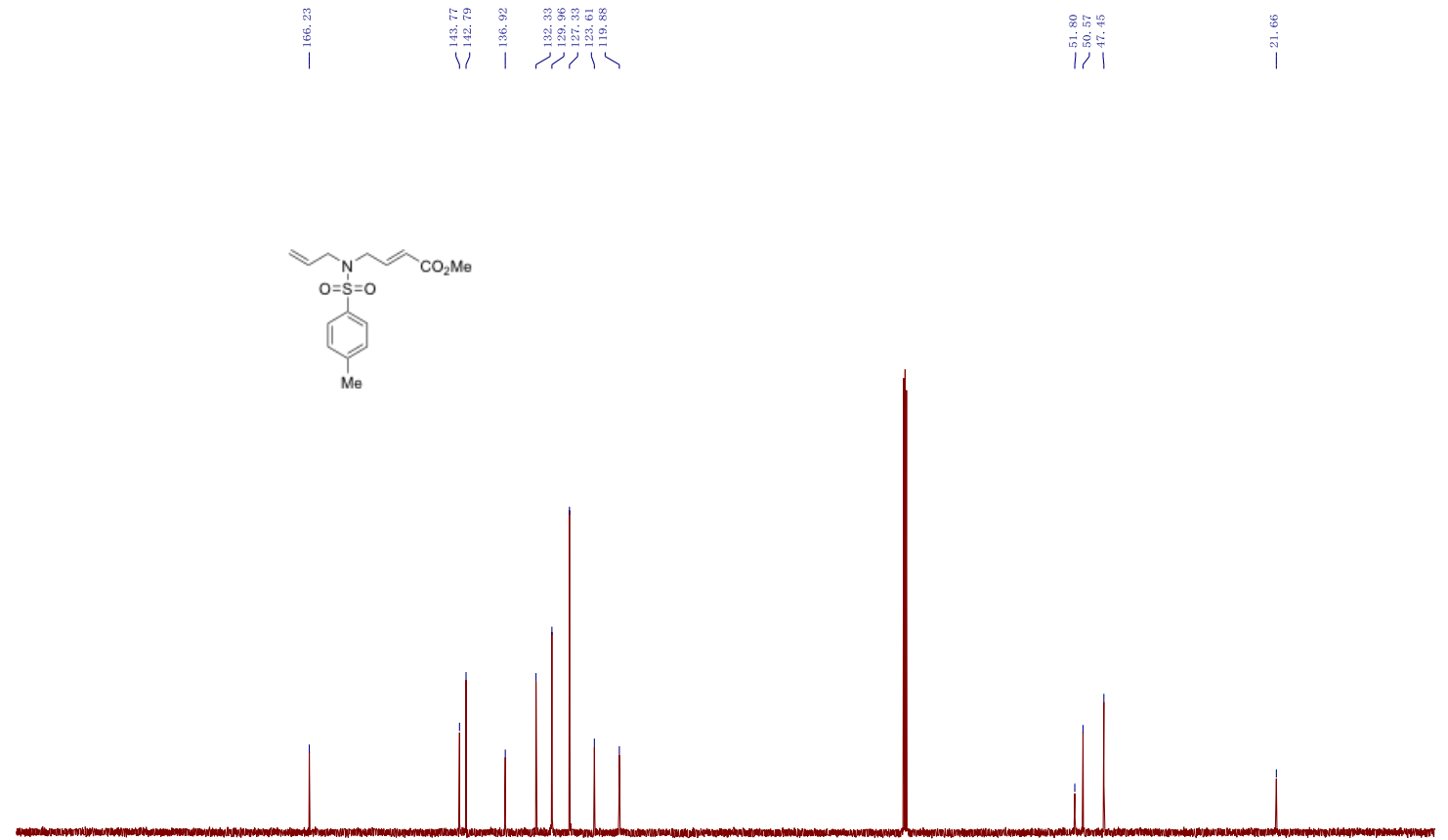

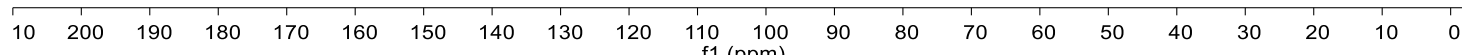


NMR of 2

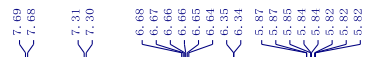

$\mathrm{MeO}_{2} \mathrm{C}$
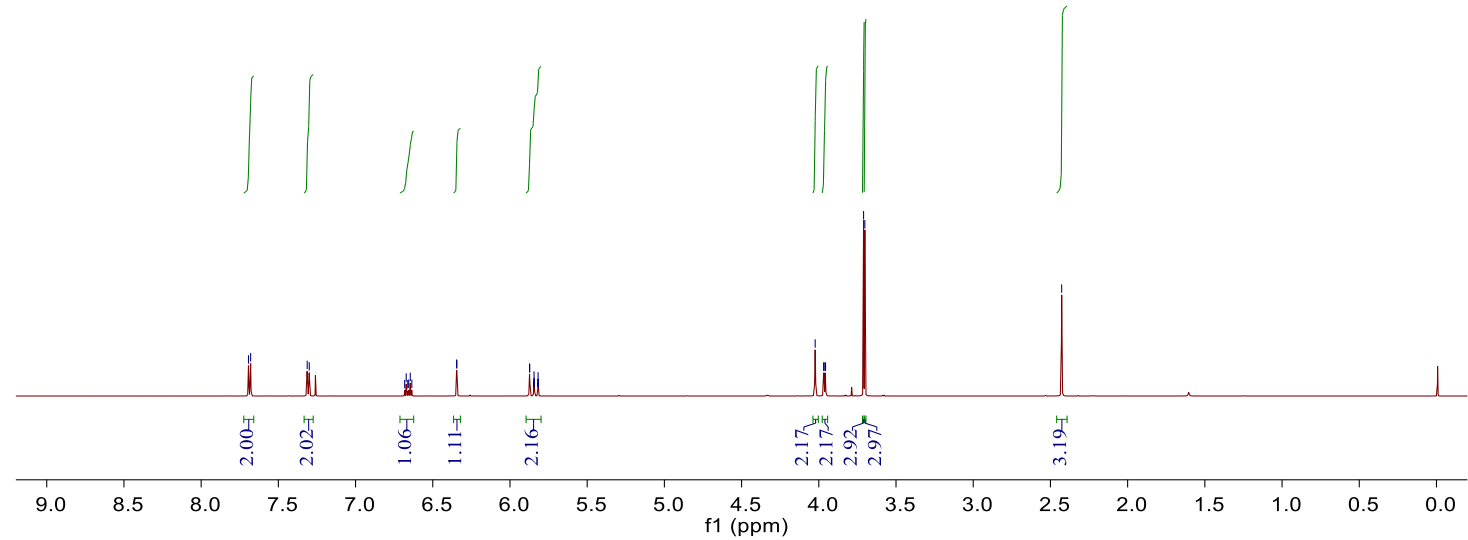

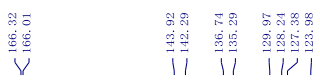

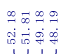

iv $\mid$
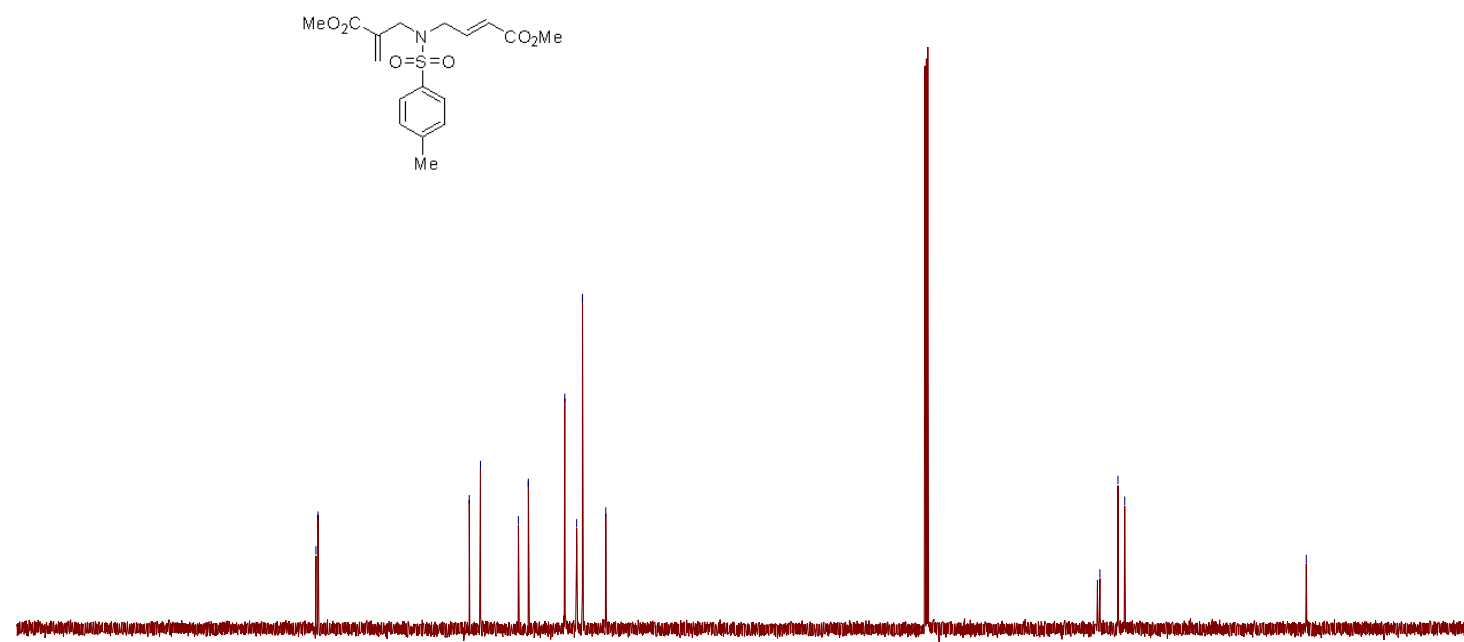

$\begin{array}{lllllllllllllllllllll}10 & 200 & 190 & 180 & 170 & 160 & 150 & 140 & 130 & 120 & 110 & 100 & 90 & 80 & 70 & 60 & 50 & 40 & 30 & 20 & 10\end{array}$ 
NMR of 3

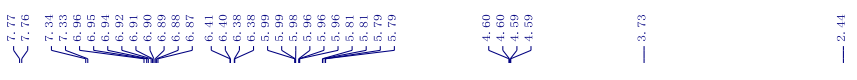

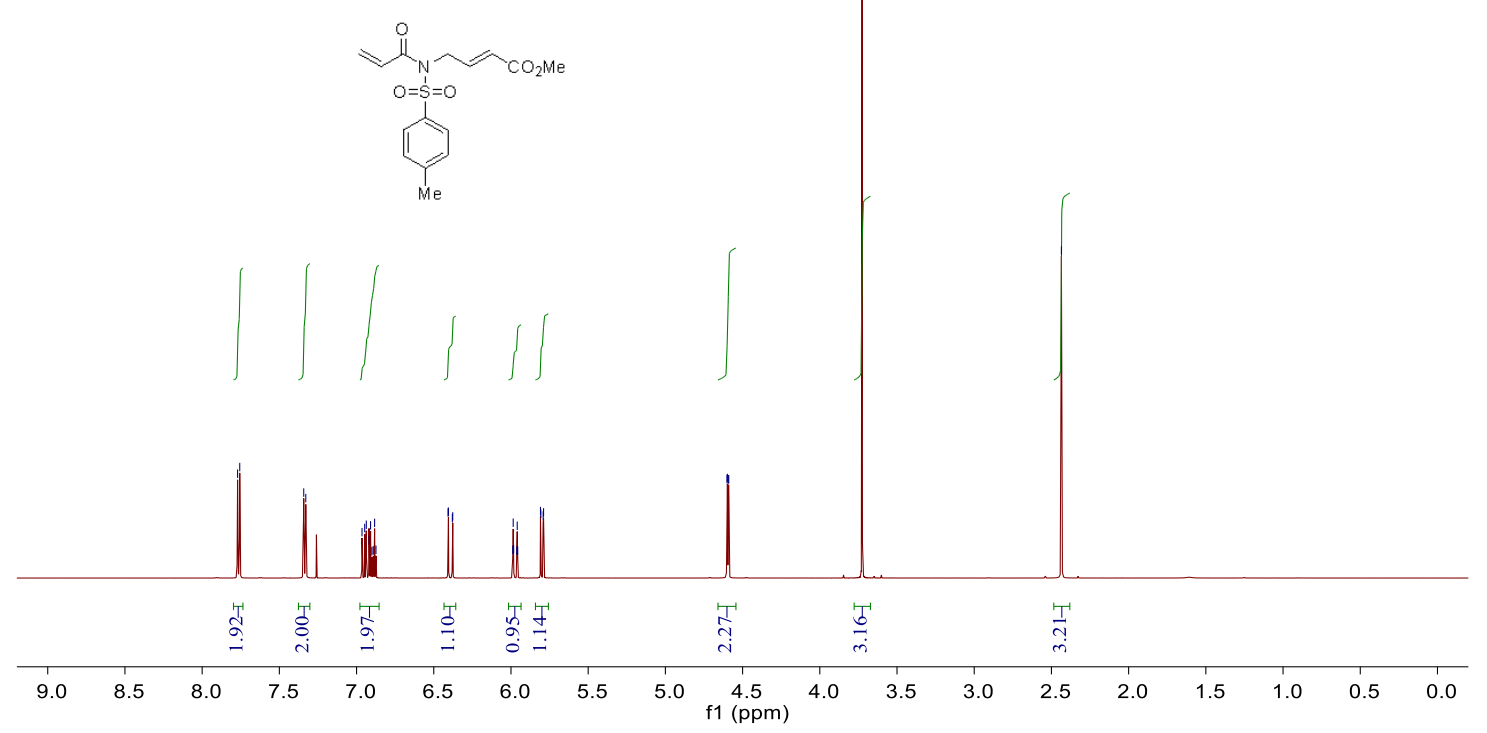

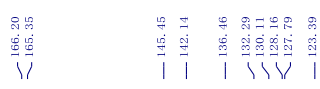

荊

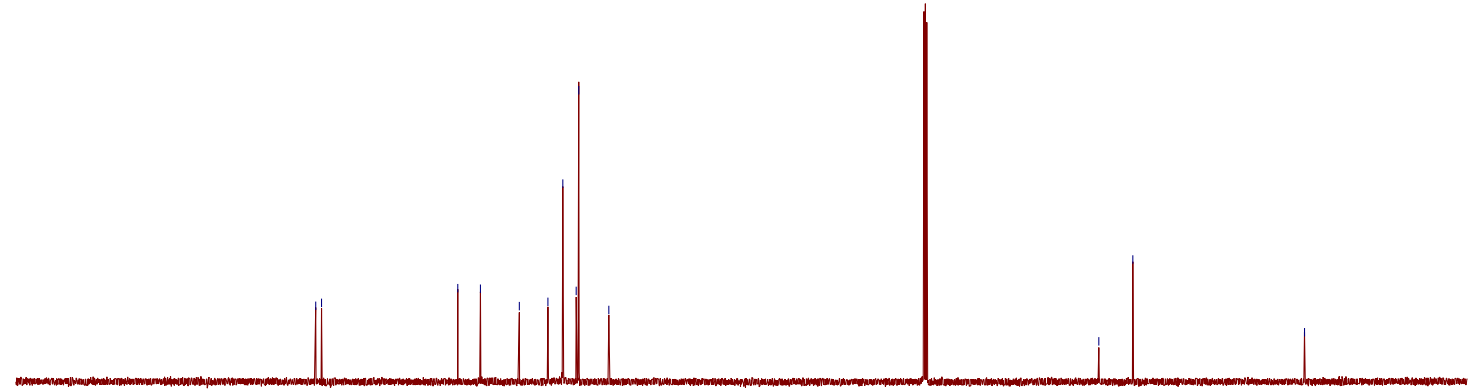

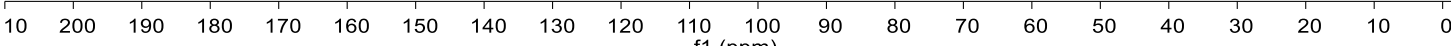
1 (ppm) 
NMR of P-1

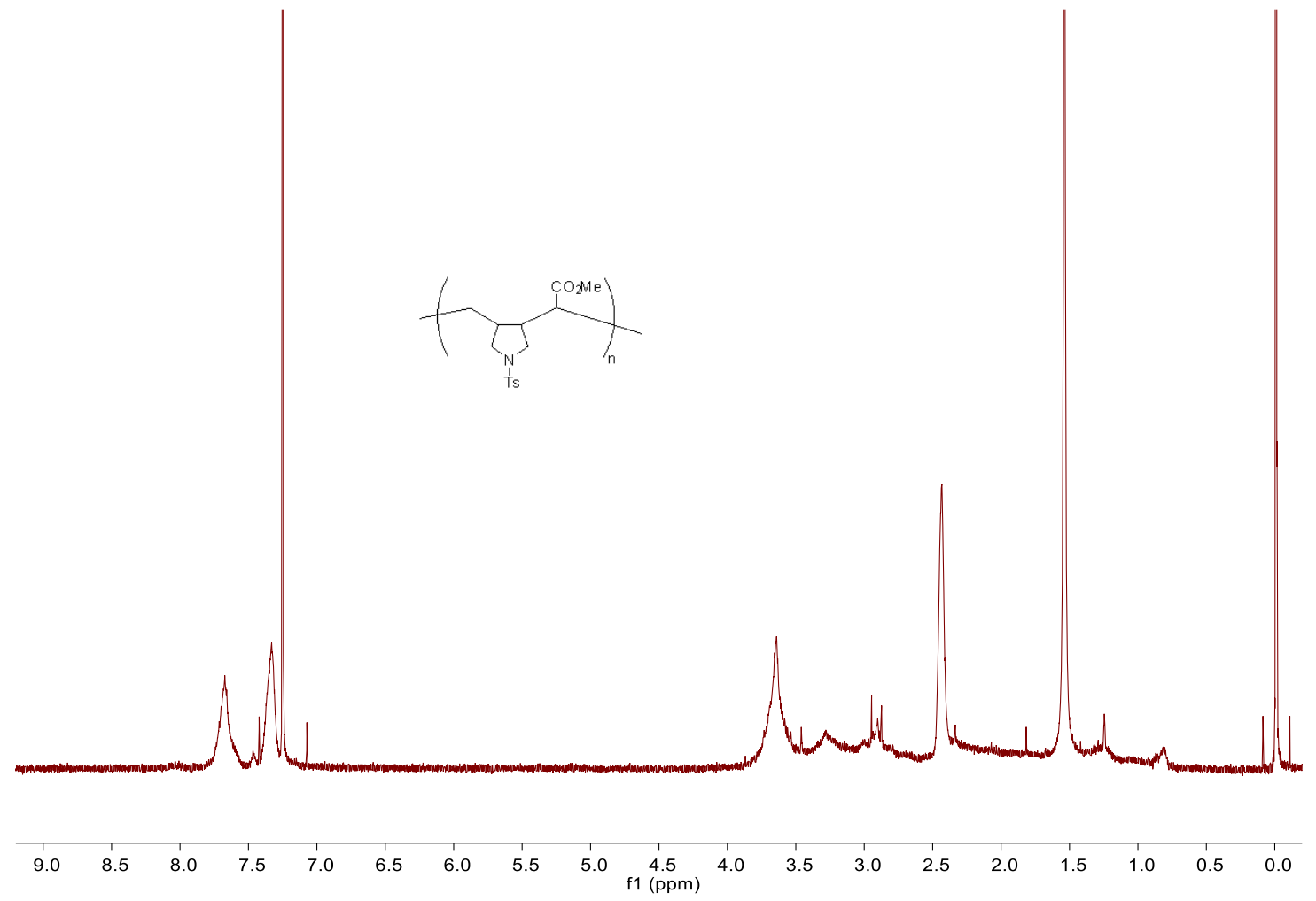


NMR of P-2

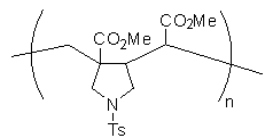

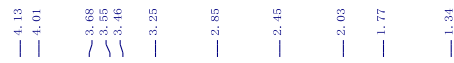
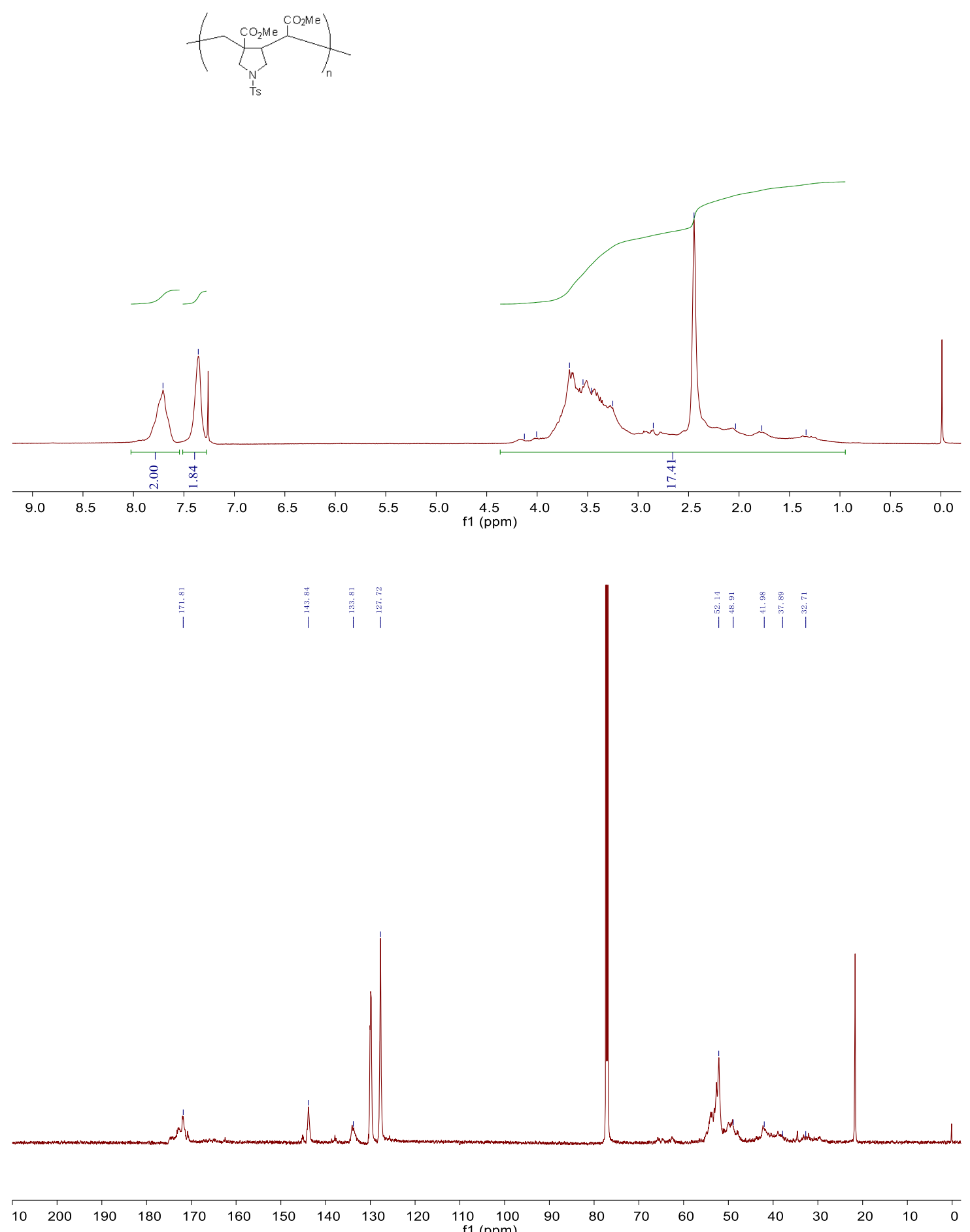
NMR of P-3

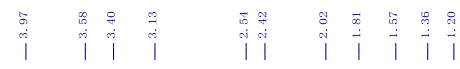

$\operatorname{rooc}_{\lambda}^{\text {nis }}$

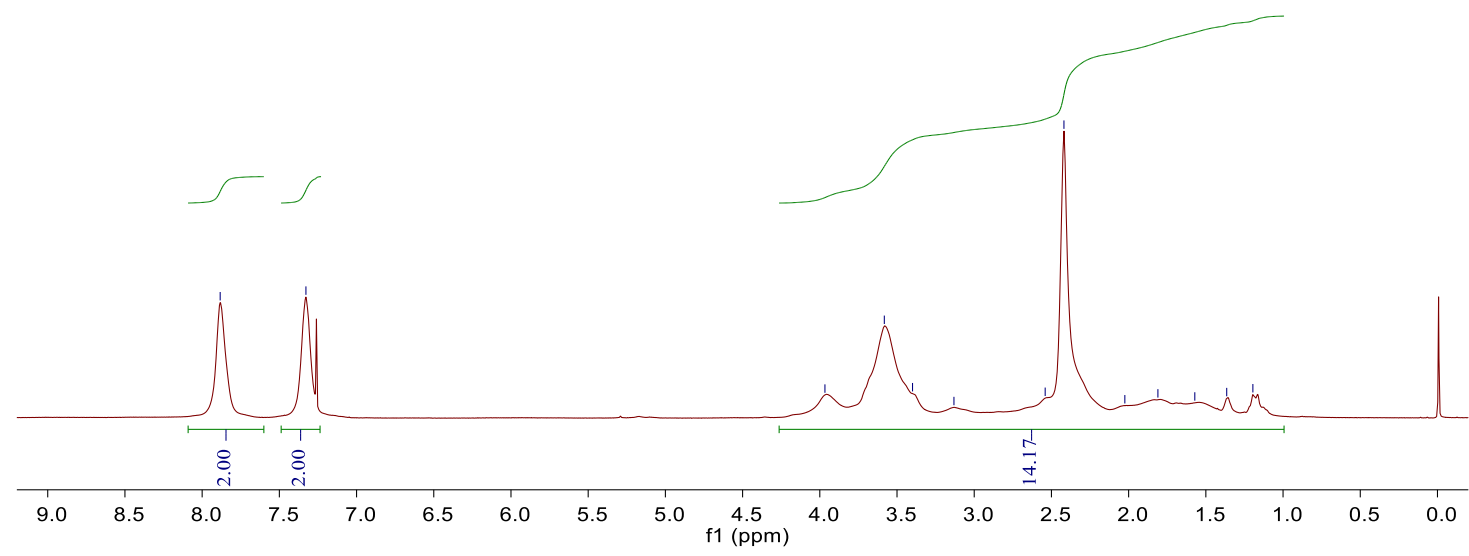

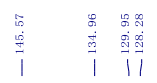

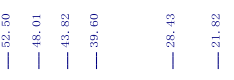

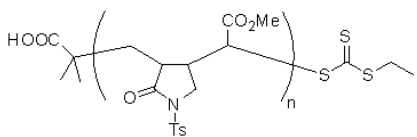

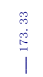
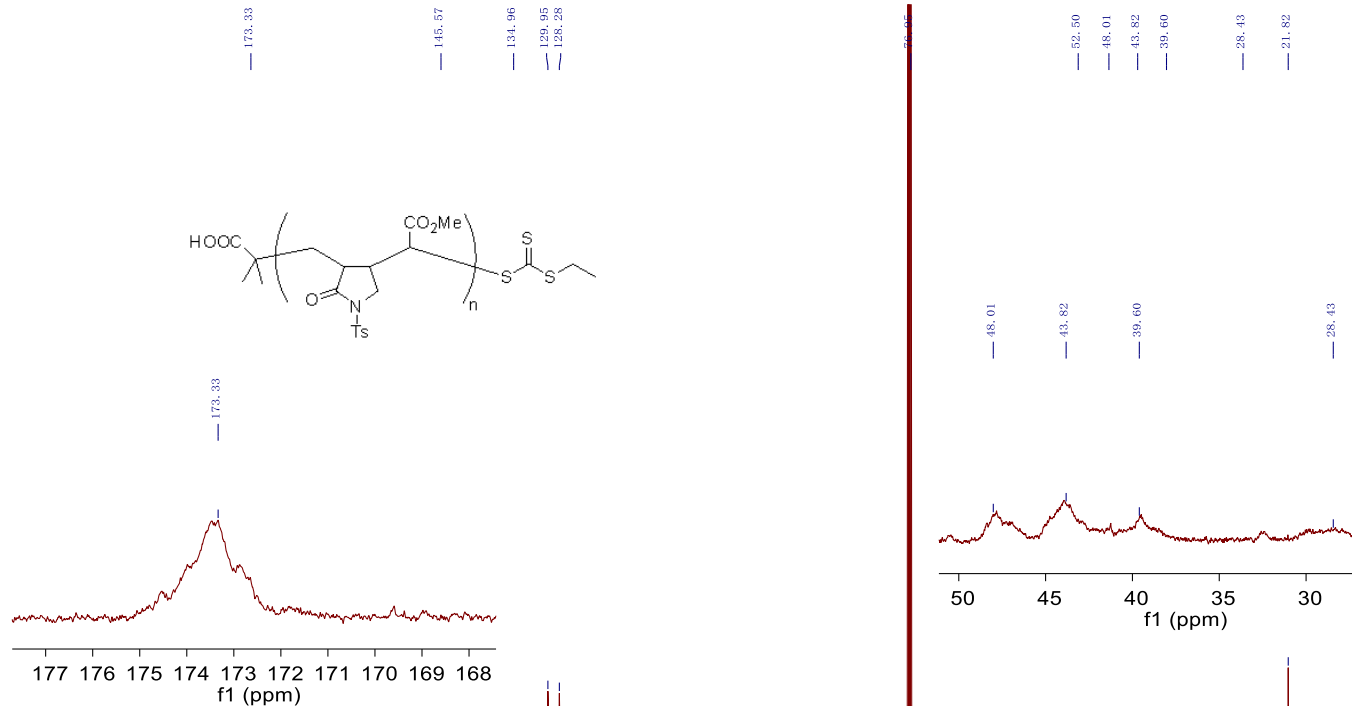

f1 (ppm)
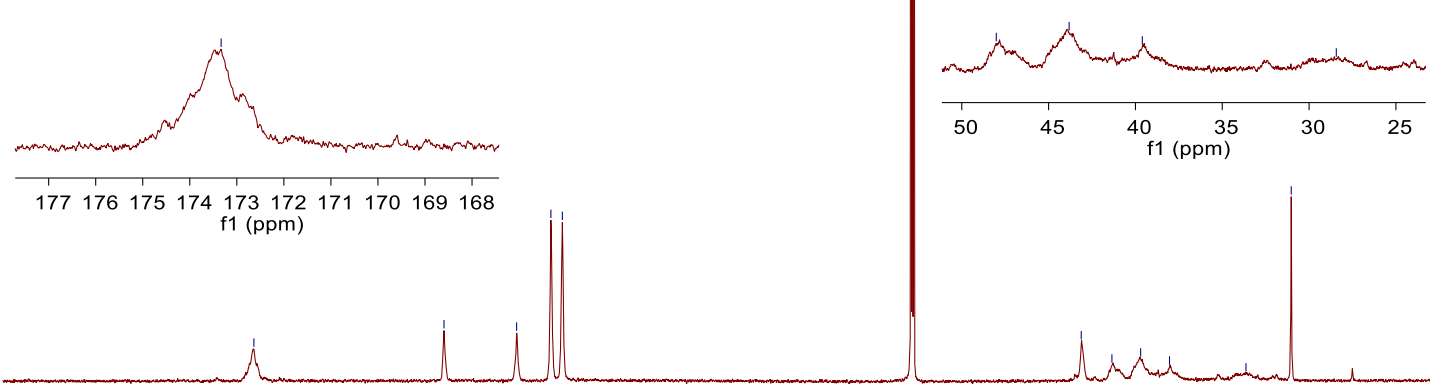

$\begin{array}{lllllllllll}200 & 190 & 180 & 170 & 160 & 150 & 140 & 130 & 120 & 110 & 100\end{array}$ 
NMR of S3

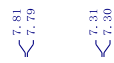

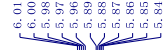

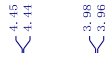

Br

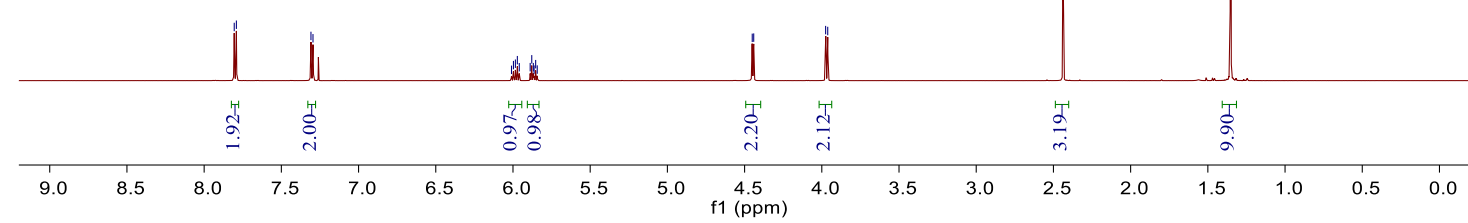

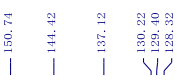
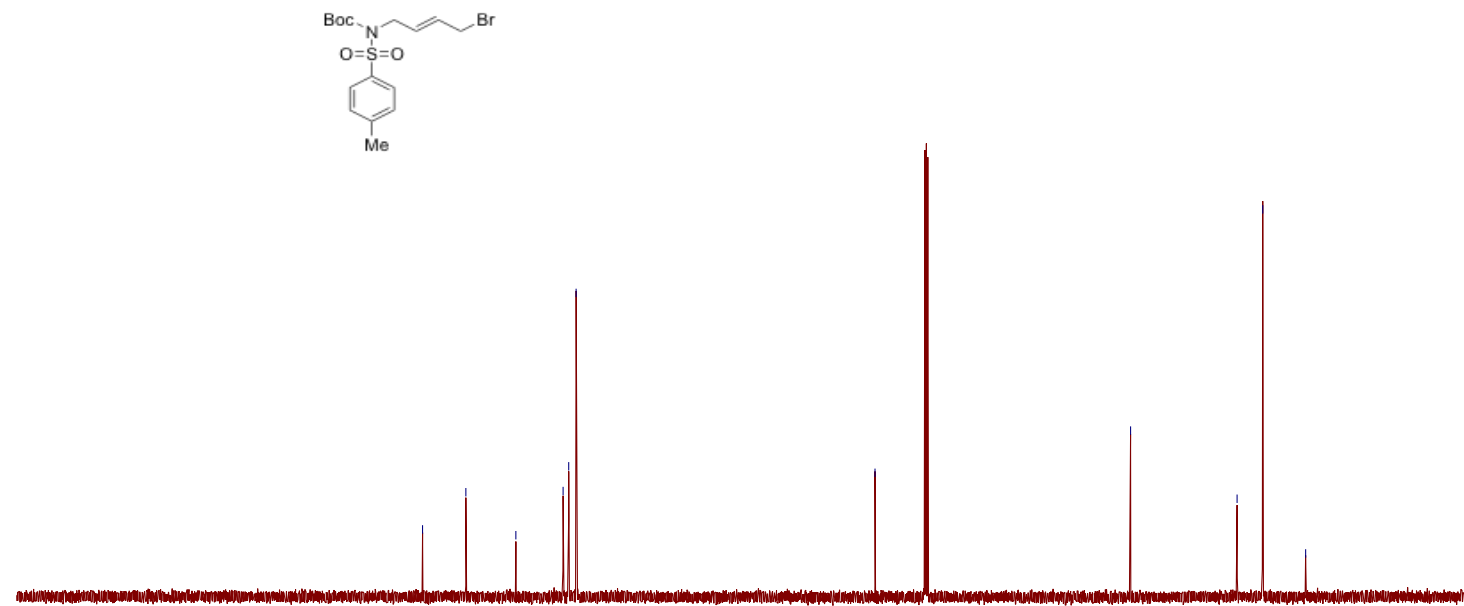

$\begin{array}{llllllllllllllllllllll}10 & 200 & 190 & 180 & 170 & 160 & 150 & 140 & 130 & 120 & 110 & 100 & 90 & 80 & 70 & 60 & 50 & 40 & 30 & 20 & 10 & 0\end{array}$ 
NMR of S4

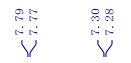

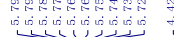
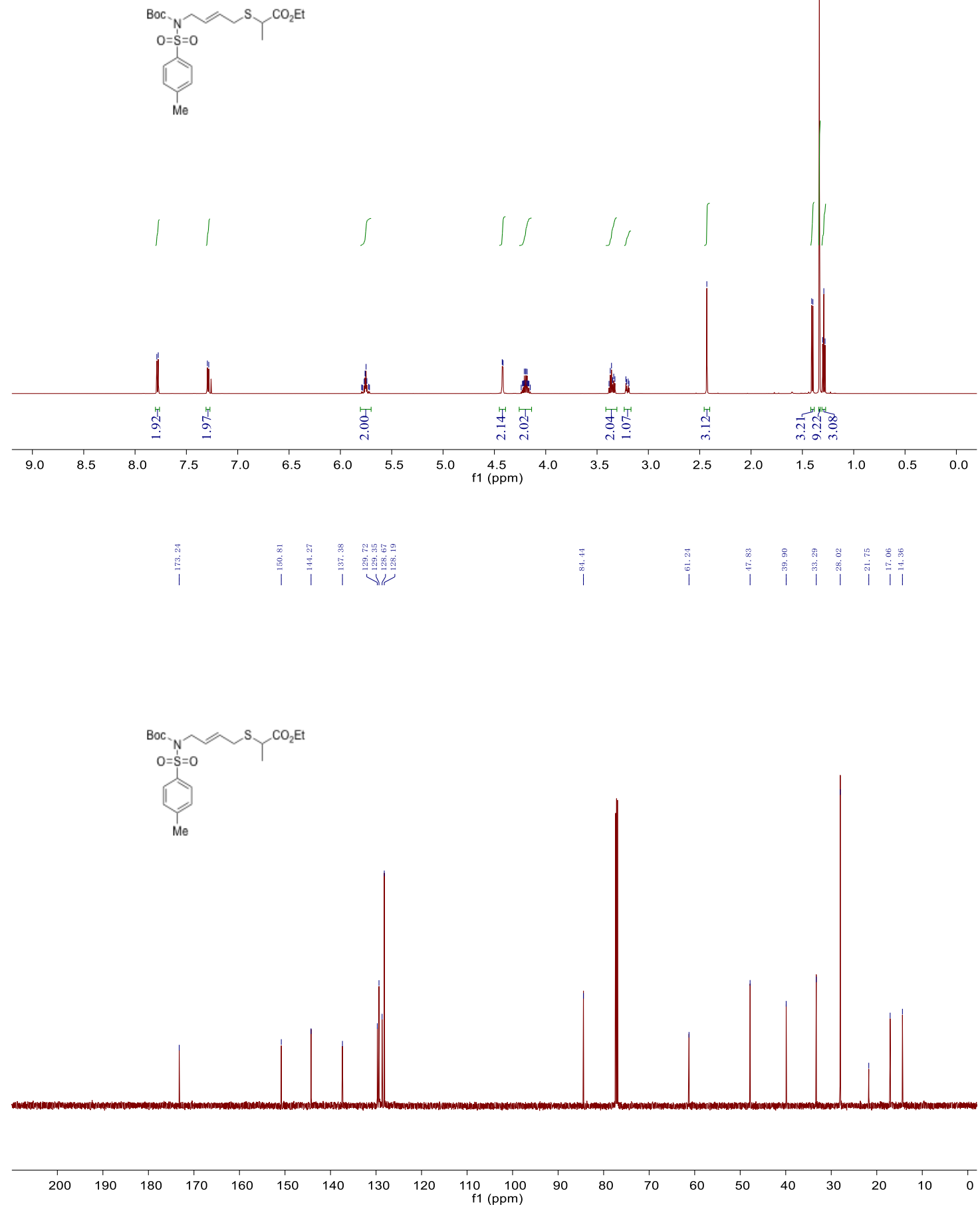
NMR of S5

崔
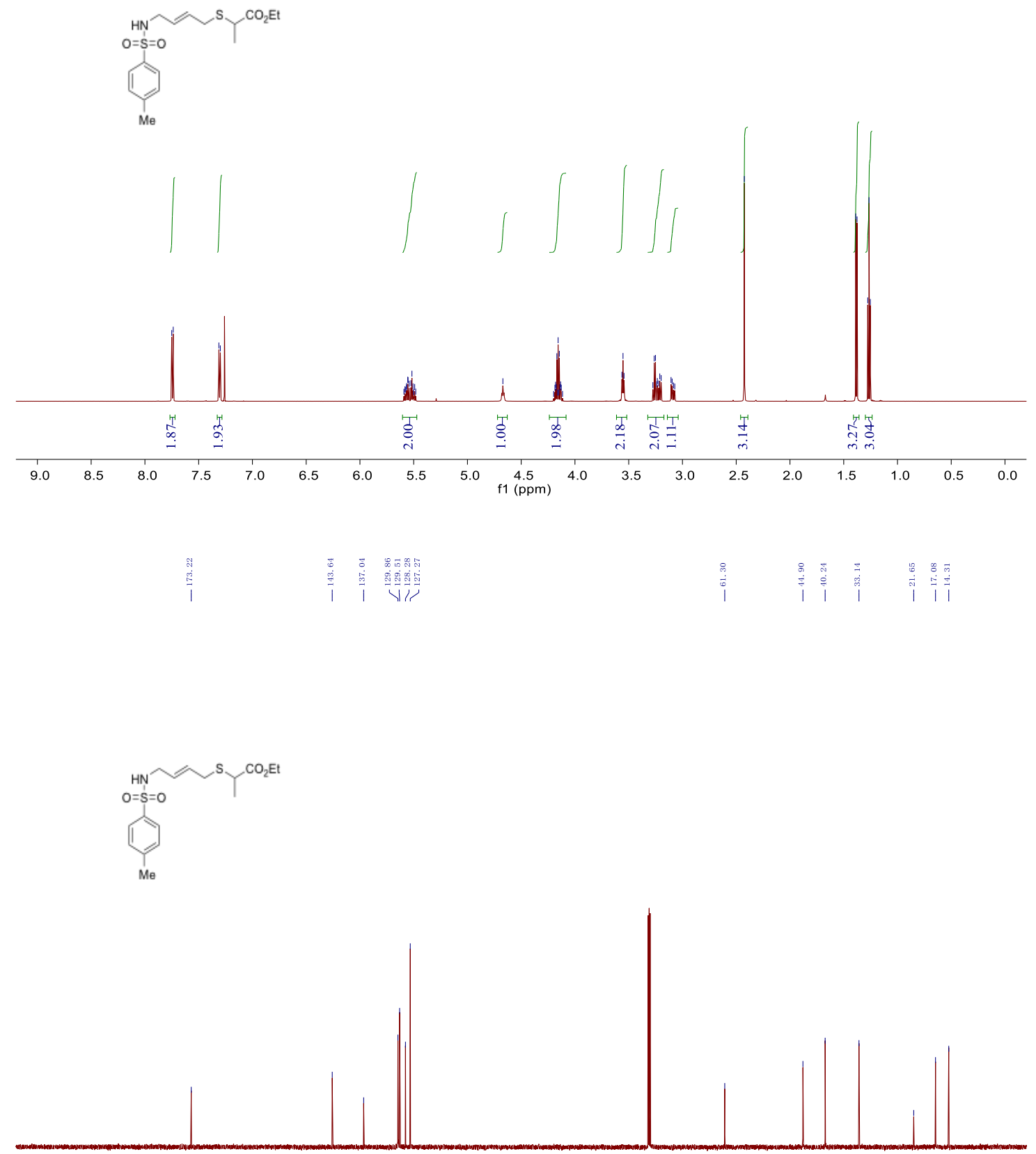

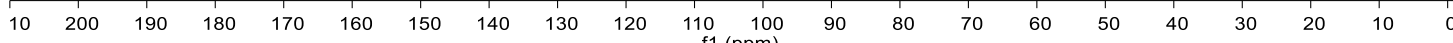


NMR of S6

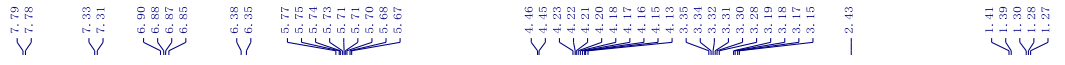

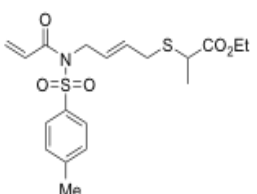

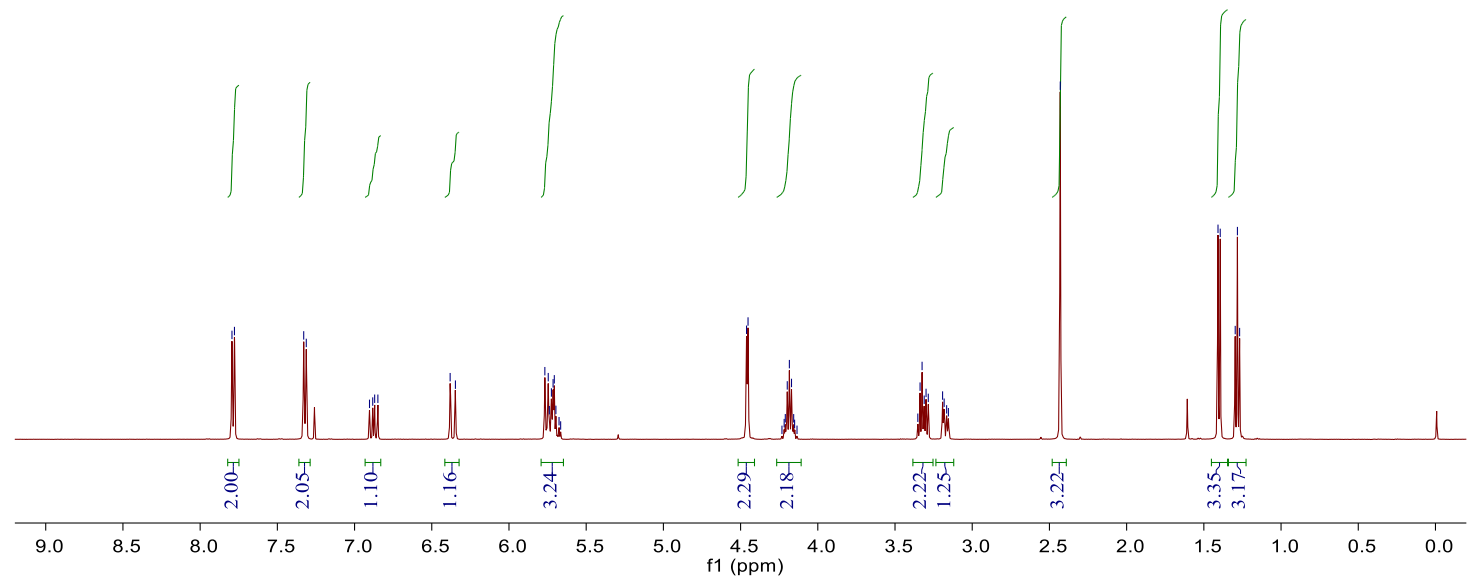

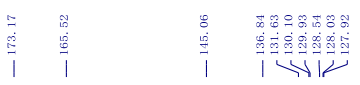

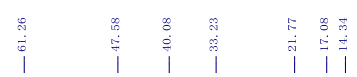
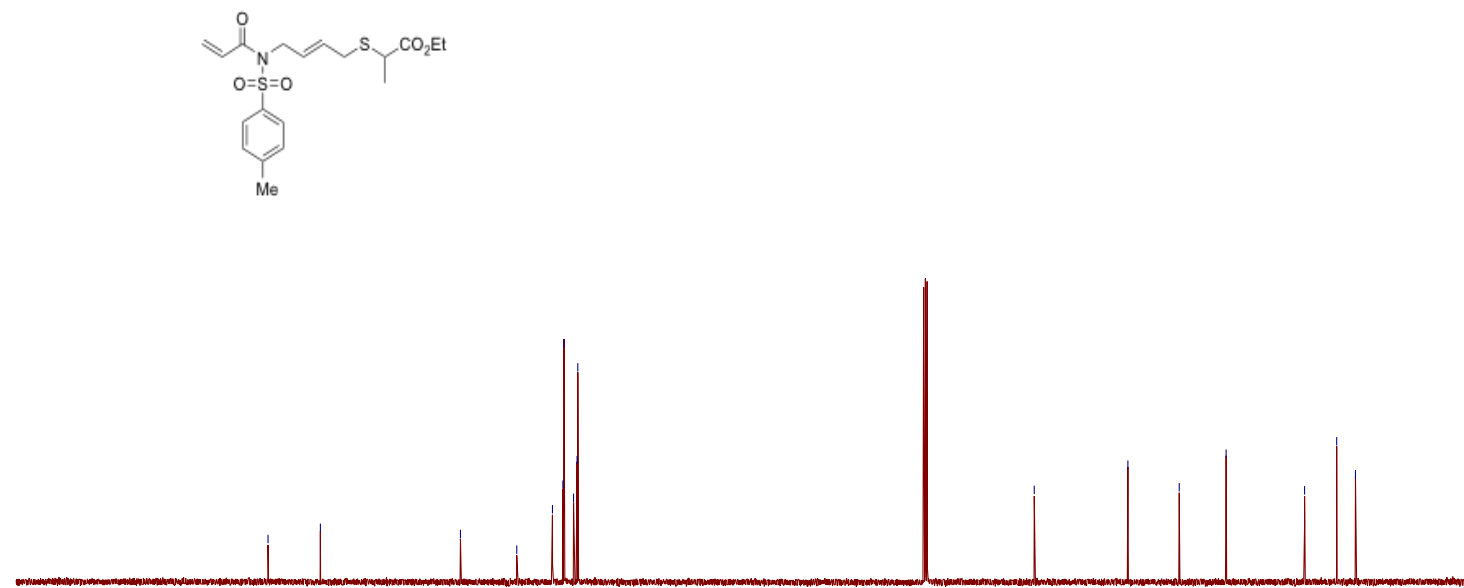

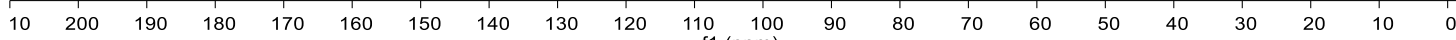


NMR of 4

V|
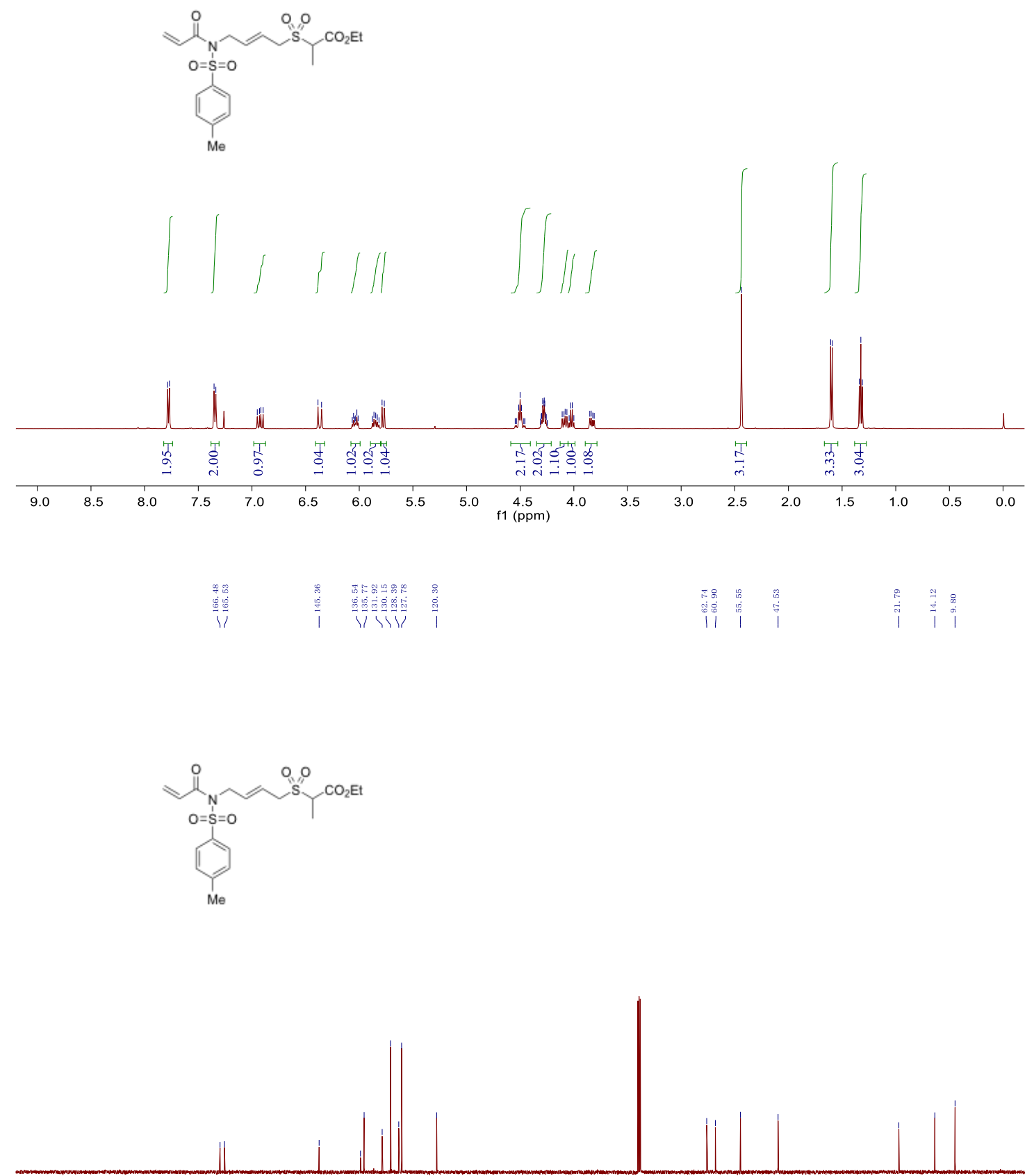

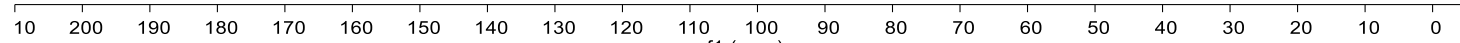




\section{NMR of 5}
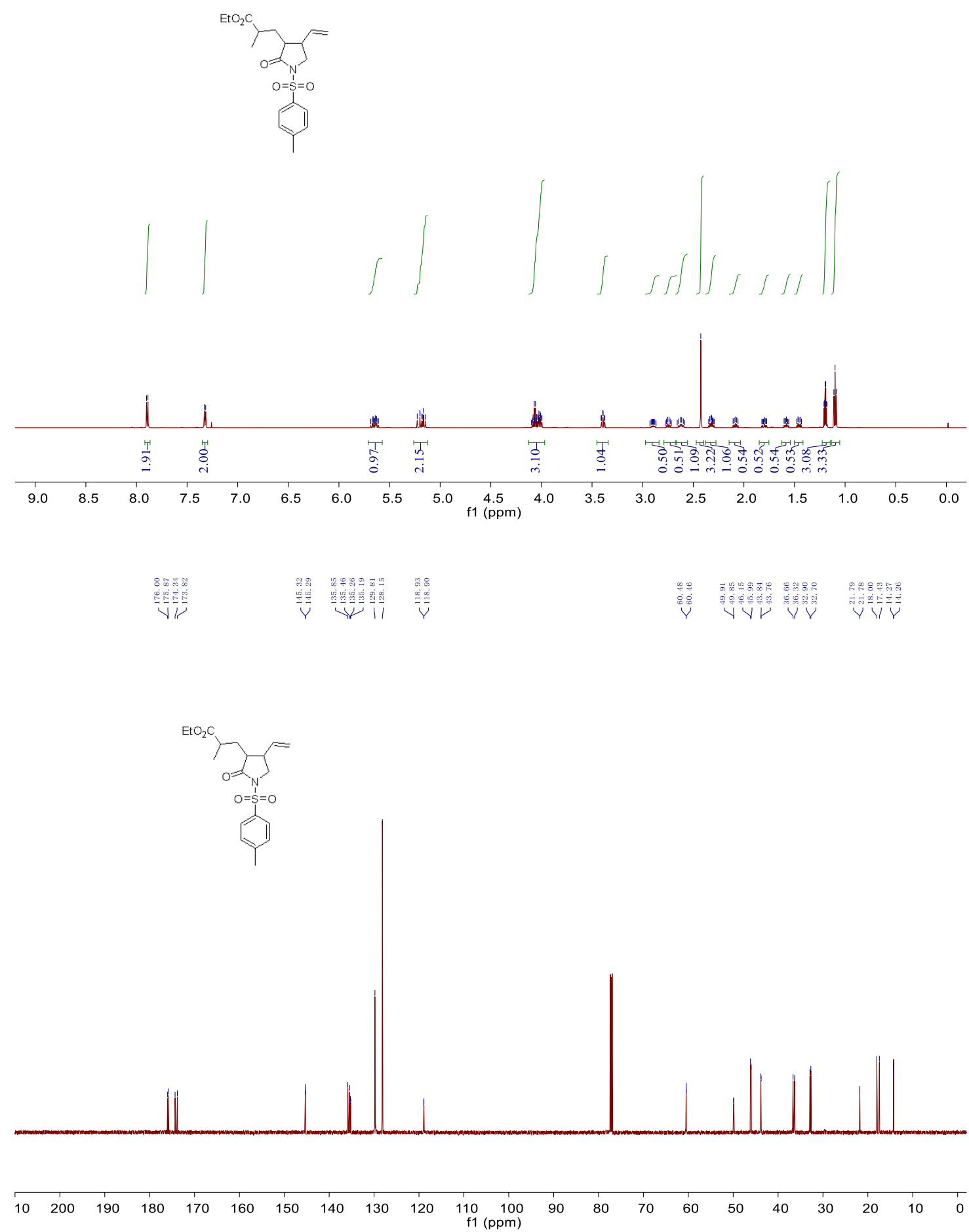
NMR of 6

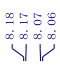

$\stackrel{\substack{\text { gog } \\ \hdashline}}{i}$

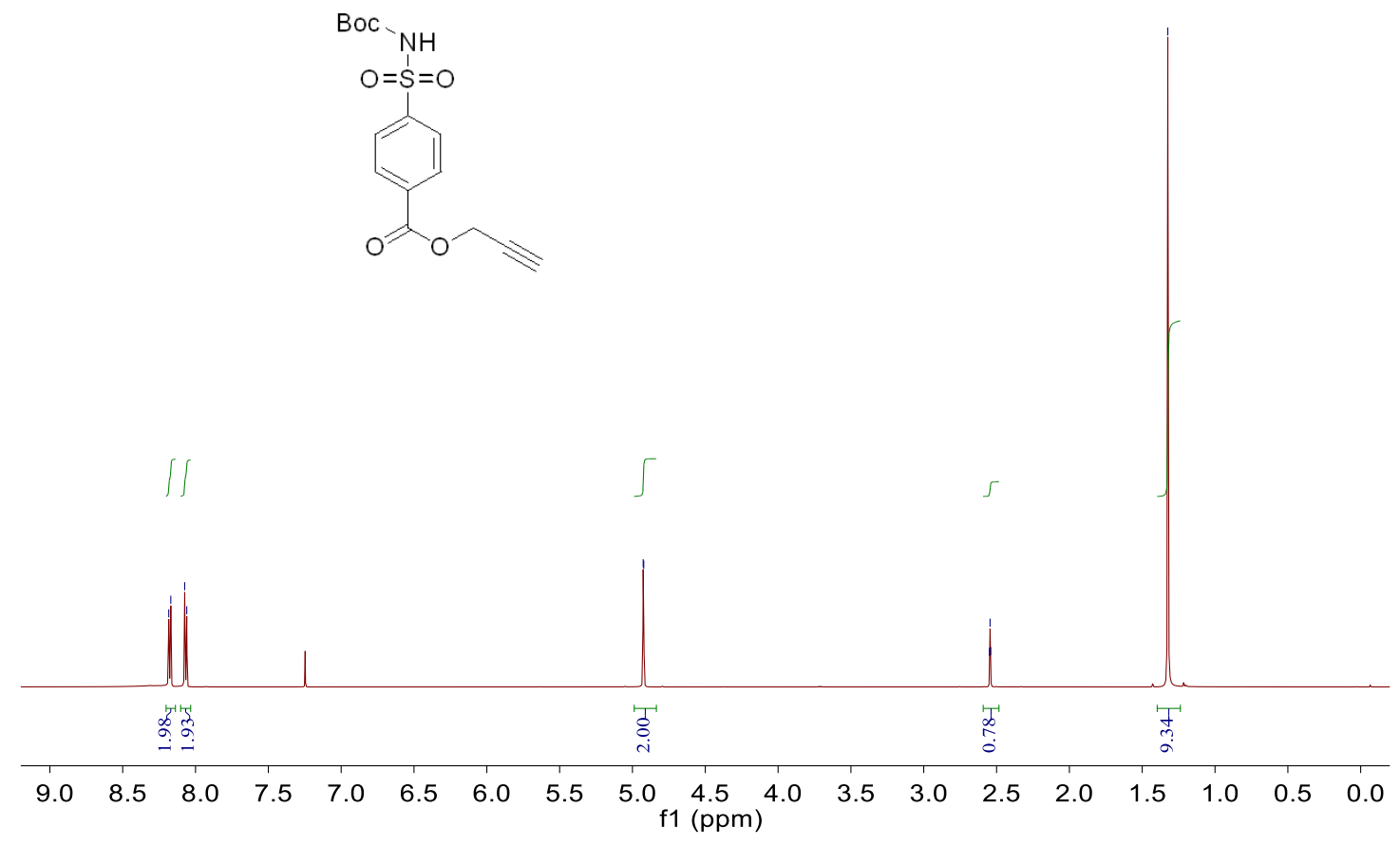

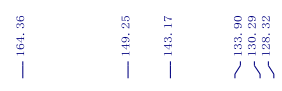
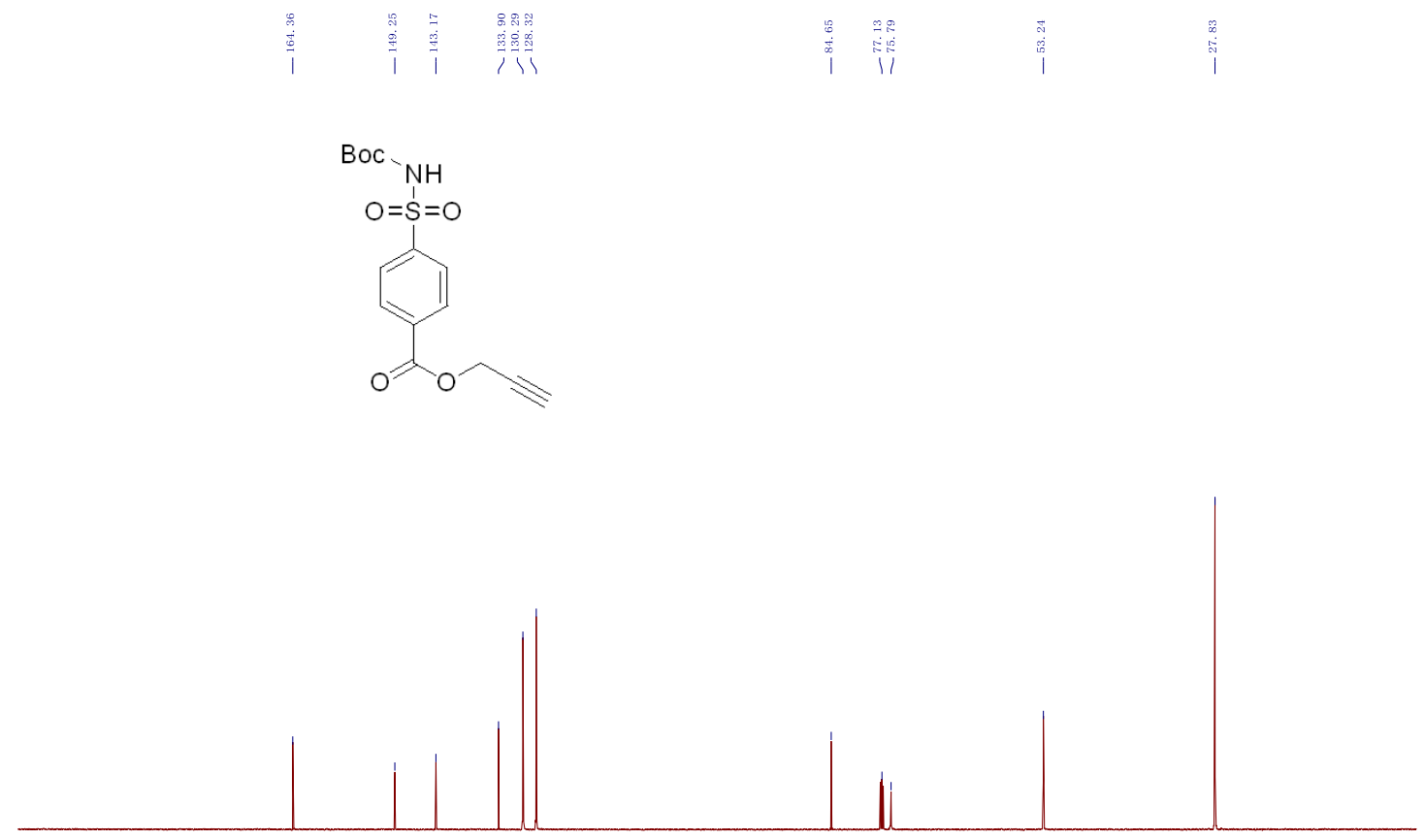

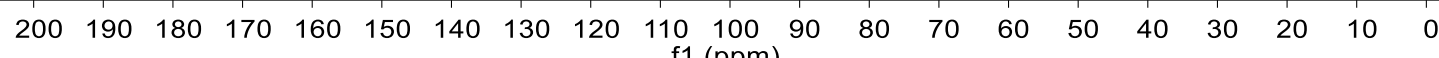
f1 (ppm) 
NMR of S7

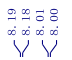

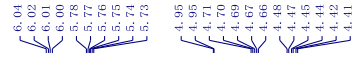

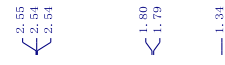

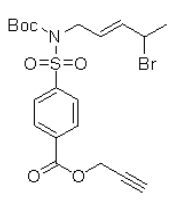

$\iint$
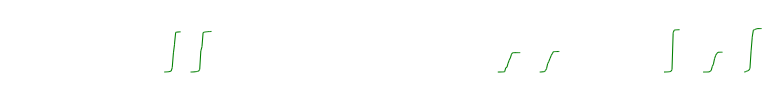

$\digamma$

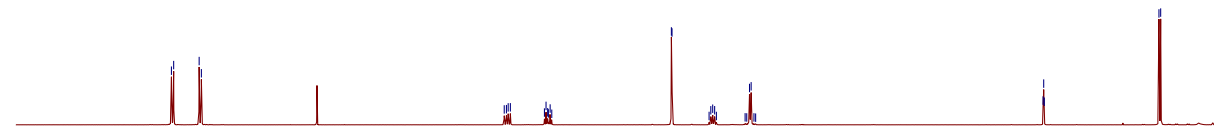

\begin{tabular}{|c|c|c|c|c|c|c|c|c|c|c|c|c|c|c|c|c|c|c|}
\hline & & 崩 & & & & & & & 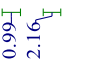 & & & & 変 & $\frac{\infty}{m}$ & ๙ู. & & & \\
\hline 9.0 & 8.5 & 8.0 & 7.5 & 7.0 & 6.5 & 6.0 & 5.5 & 5.0 & $\begin{array}{c}4.5 \\
\mathrm{f} 1(\mathrm{ppm})\end{array}$ & 4.0 & 3.5 & 3.0 & 2.5 & 2.0 & 1.5 & 1.0 & 0.5 & 0.0 \\
\hline
\end{tabular}

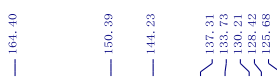
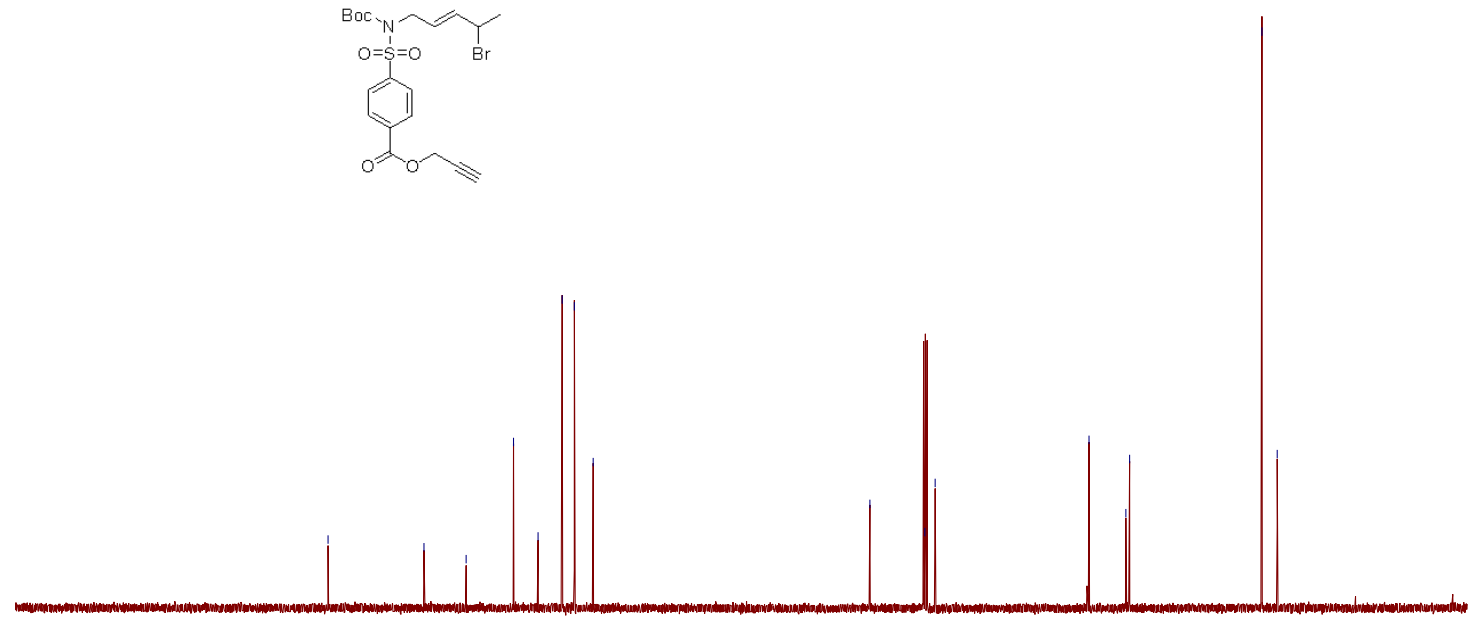

$\begin{array}{llllllllllll}10 & 200 & 190 & 180 & 170 & 160 & 150 & 140 & 130 & 120 & 110 & 100\end{array}$ 
NMR of 7

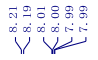
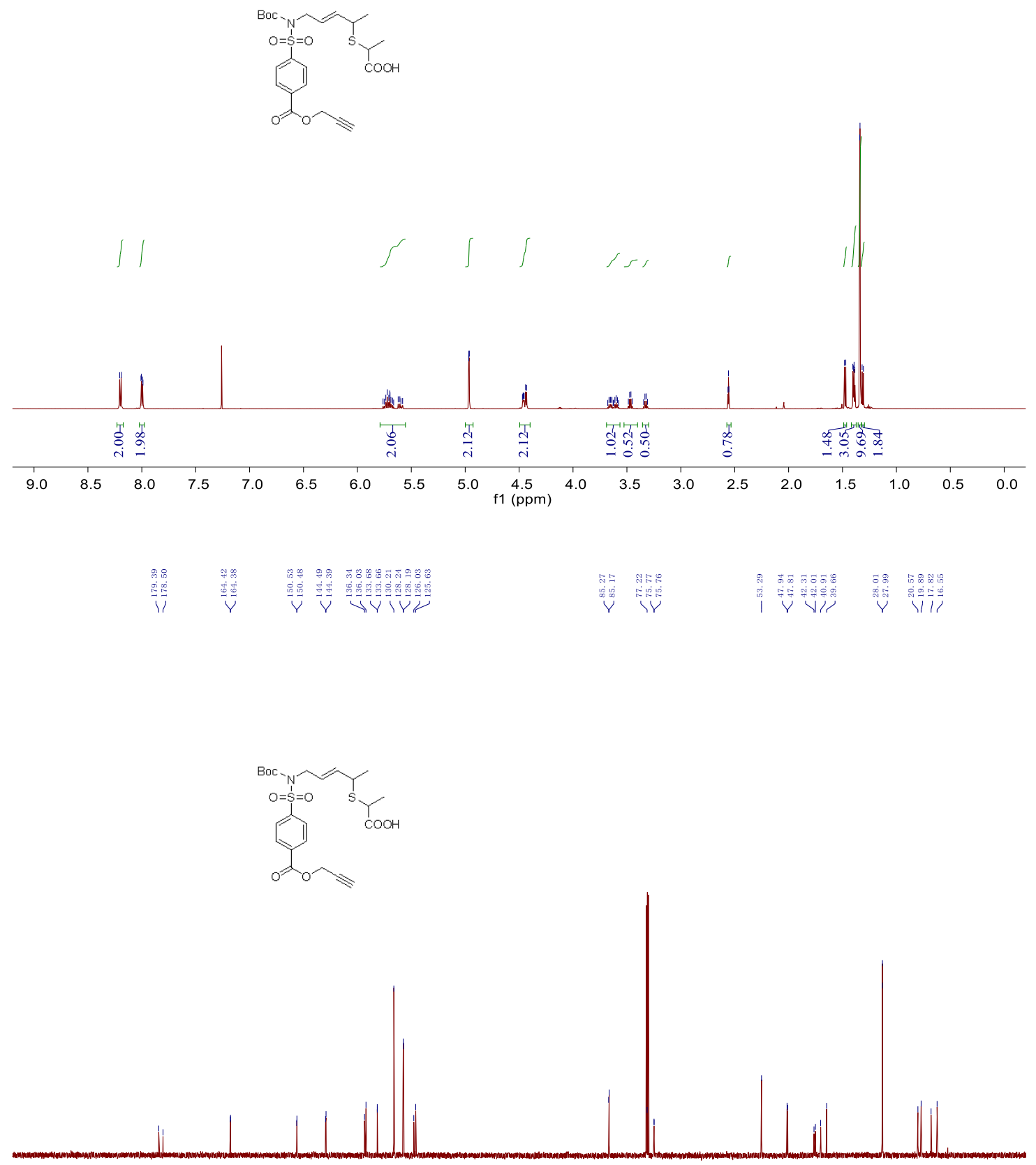

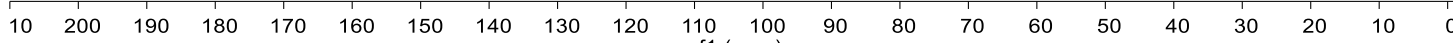
f1 (ppm) 
NMR of S8

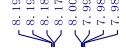
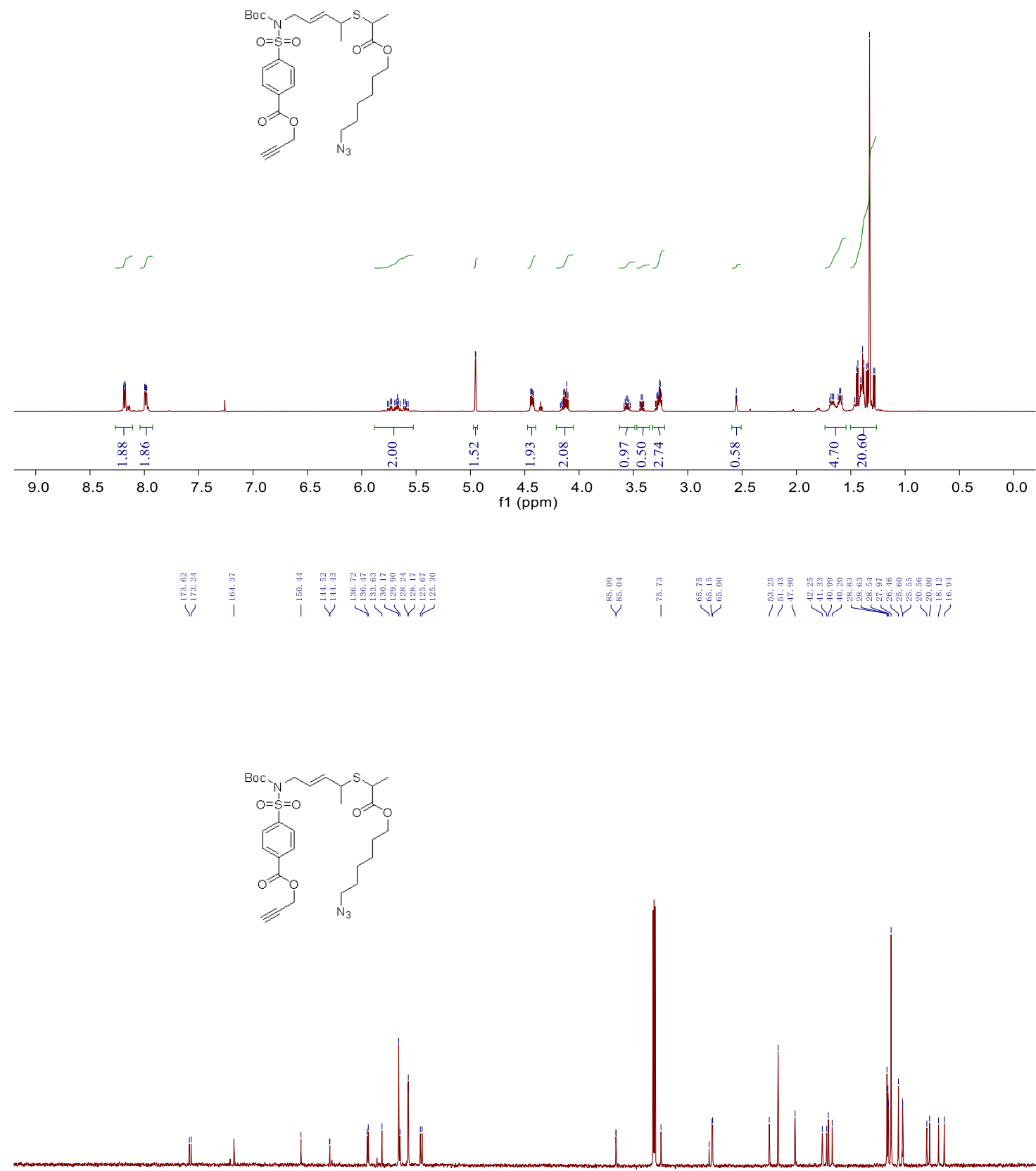

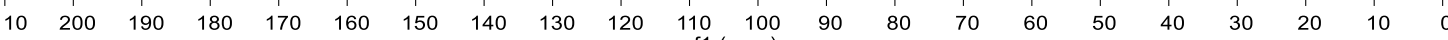
f1 (ppm) 


\section{NMR of 8}

$\underbrace{20}$
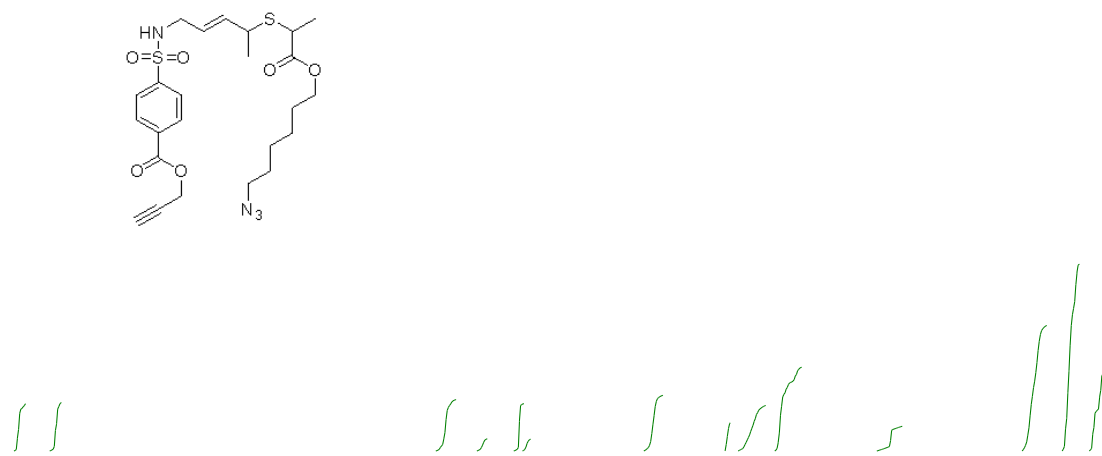

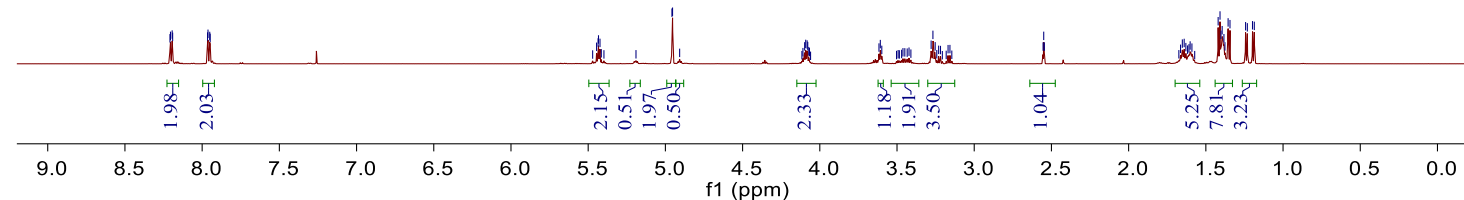
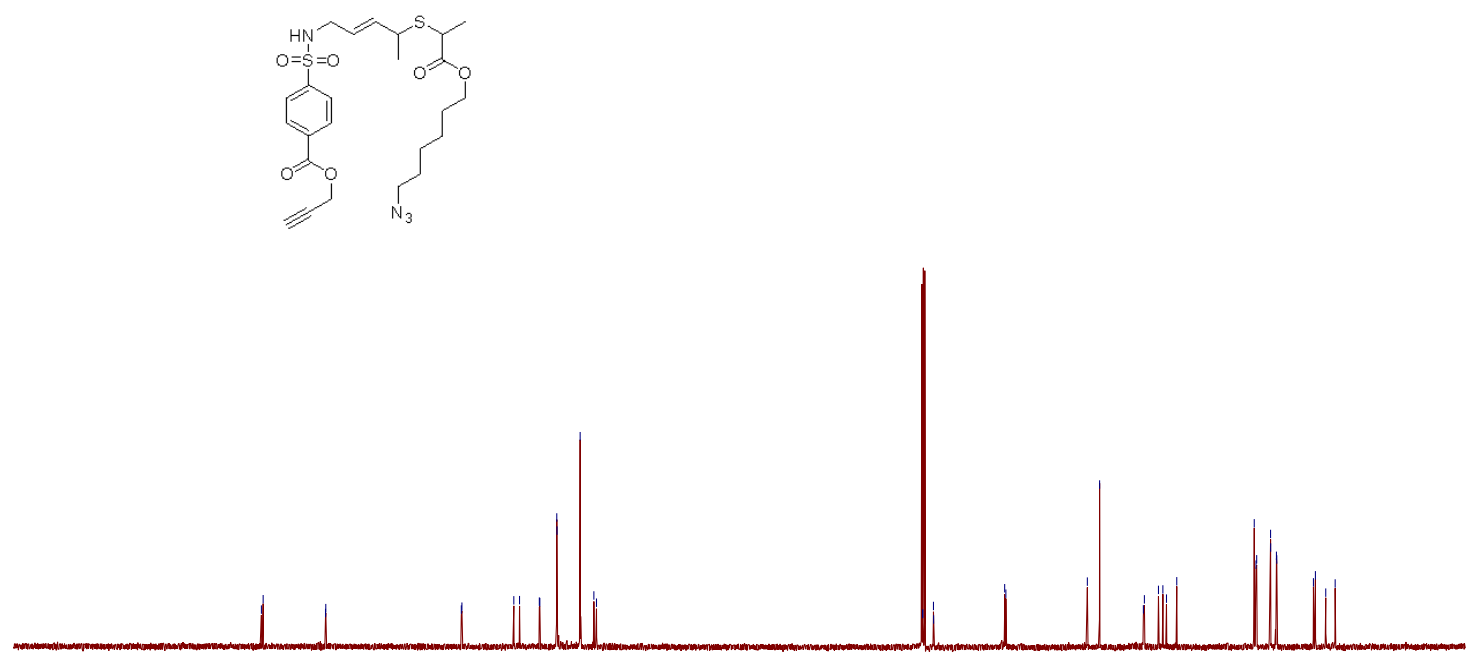

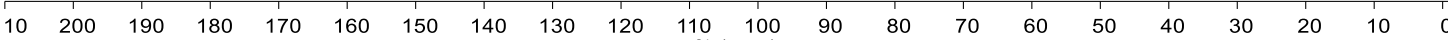


NMR of 9

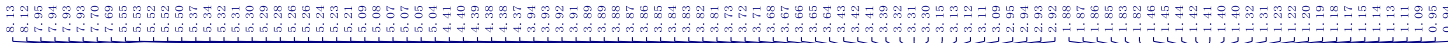

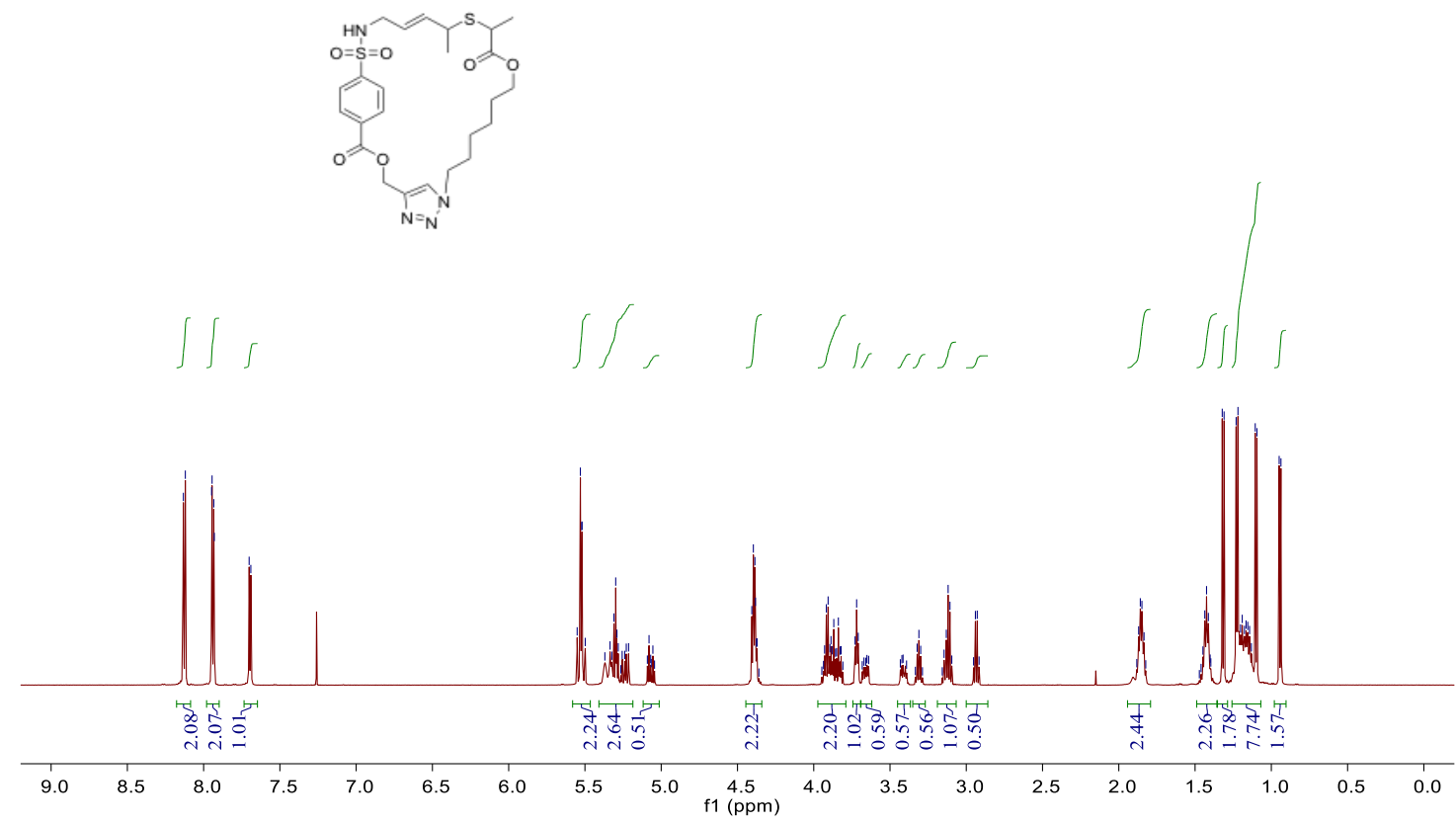

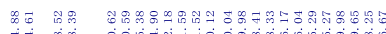

Y
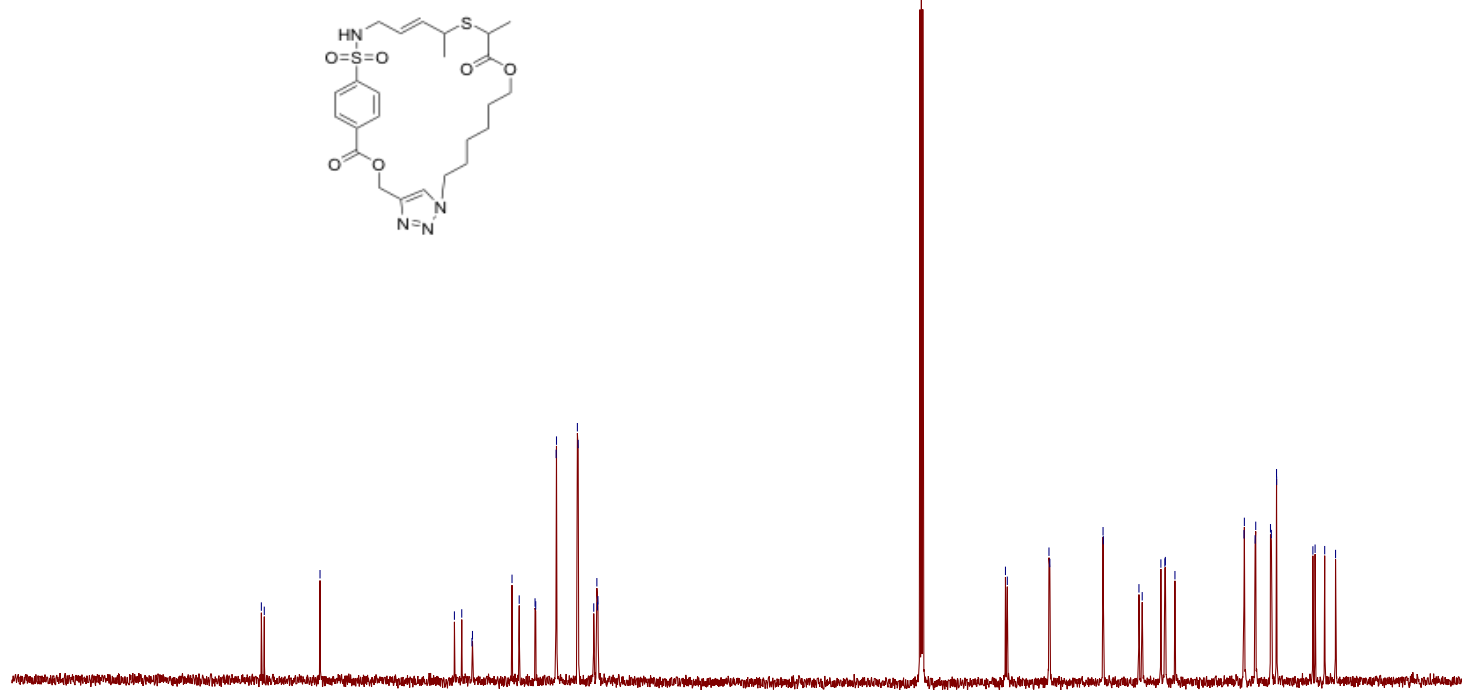

$\begin{array}{llllllllllllllllllllll}10 & 200 & 190 & 180 & 170 & 160 & 150 & 140 & 130 & 120 & 110 & 100 & 90 & 80 & 70 & 60 & 50 & 40 & 30 & 20 & 10 & 0\end{array}$ 
NMR of $\mathbf{1 0}$

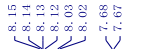

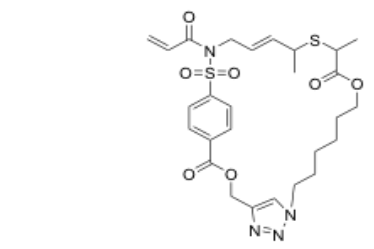

$\left.\int 1 \iint 1\right)$
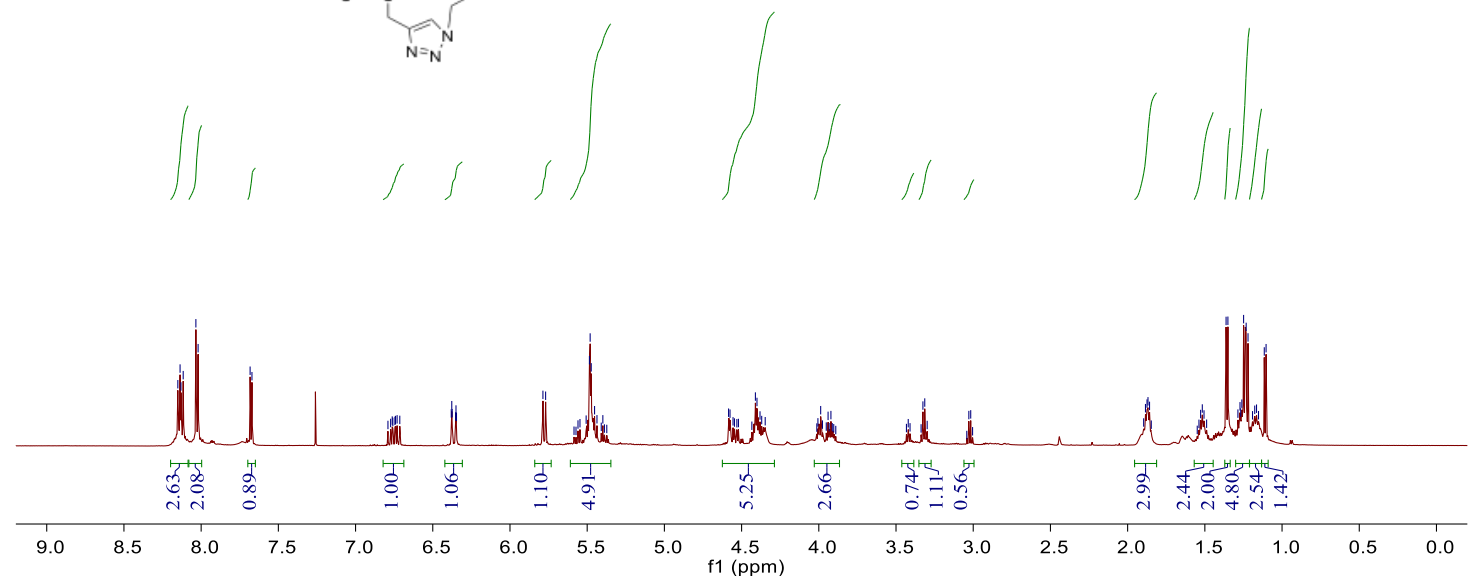

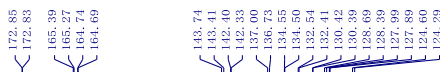

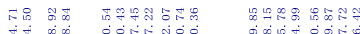

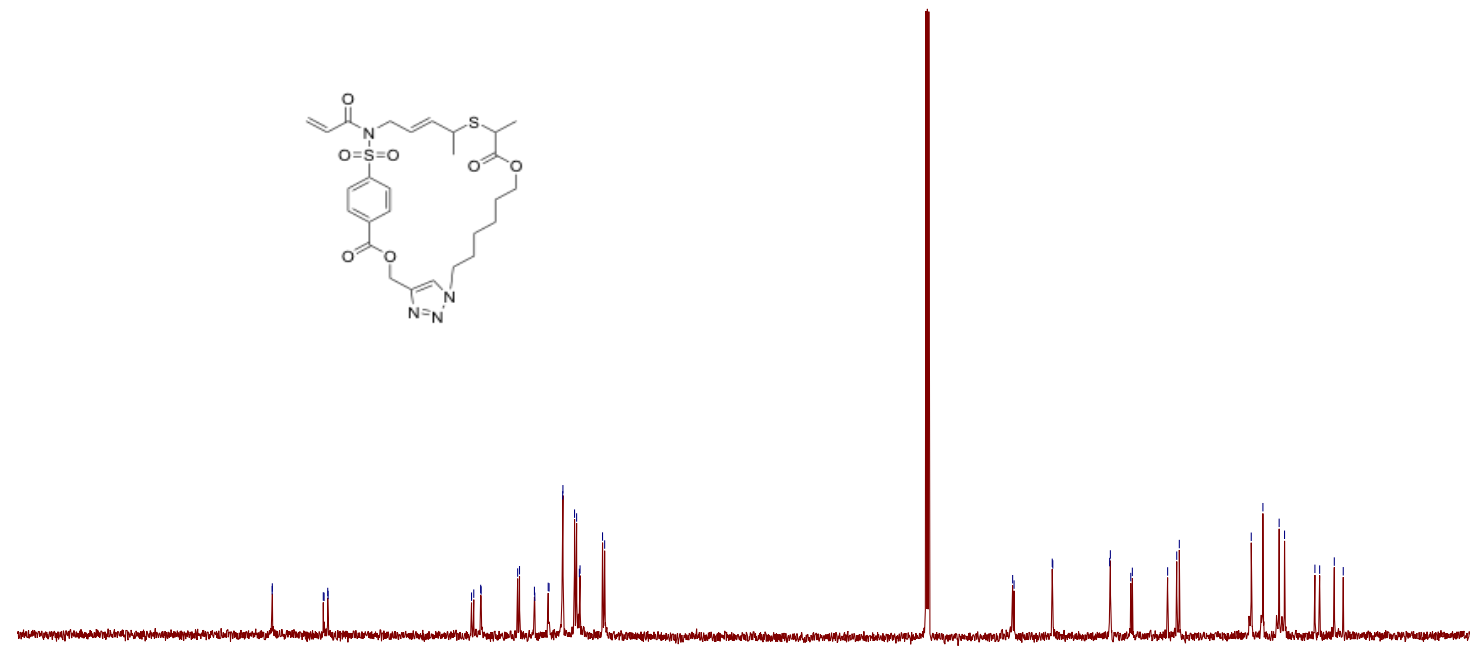

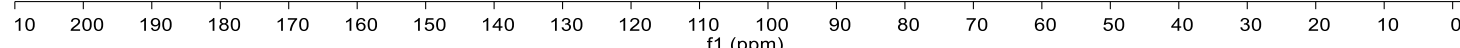


NMR of $\mathbf{1 1}$

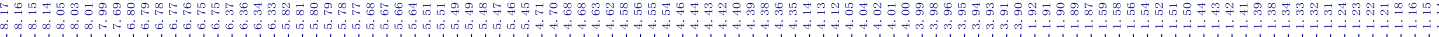

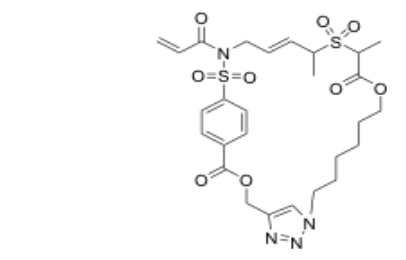
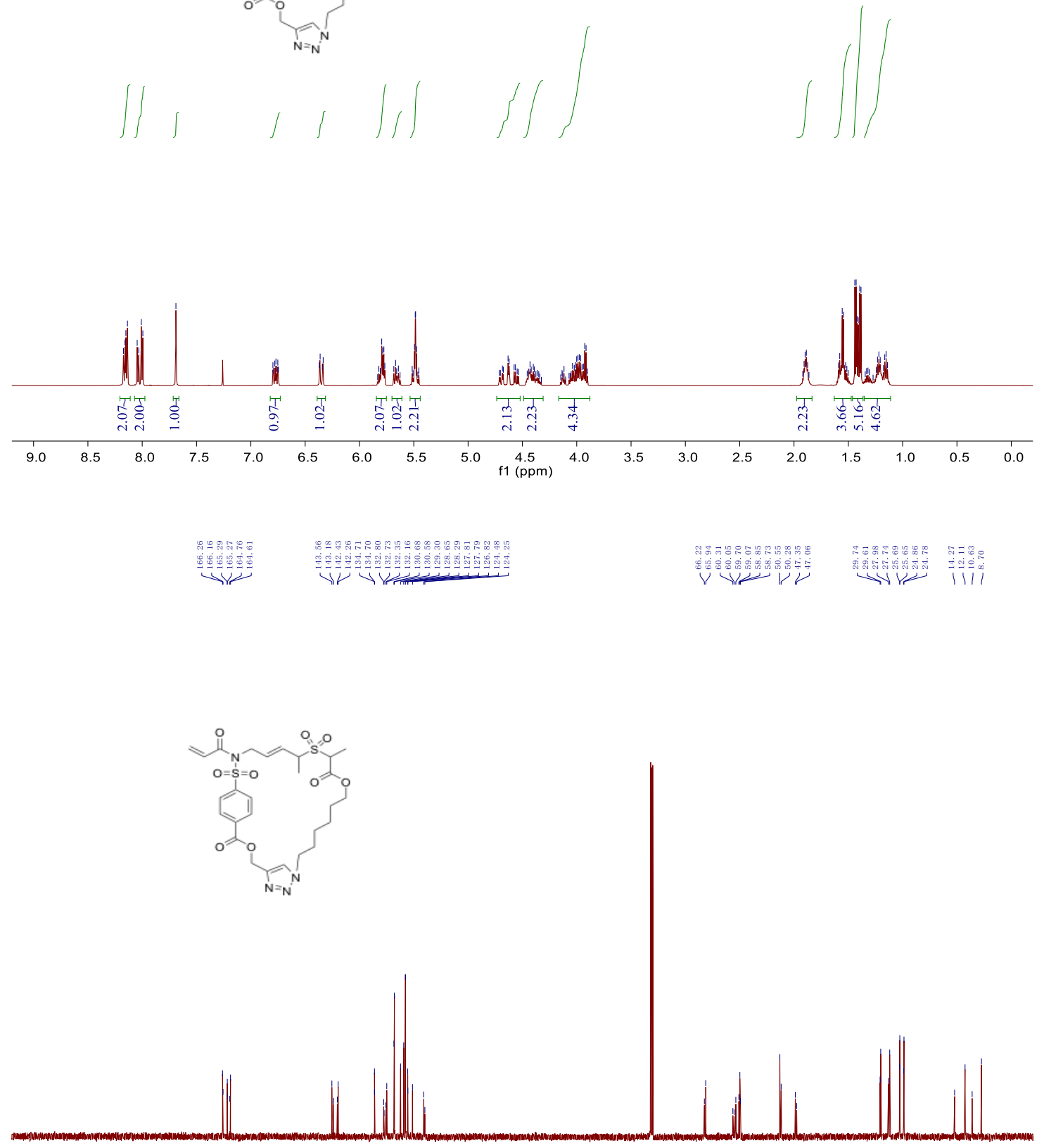

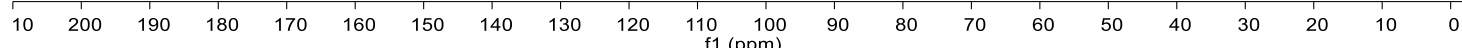


NMR of S9

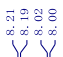

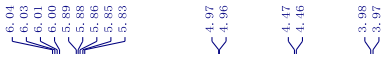

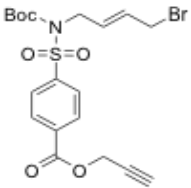

$\iint$
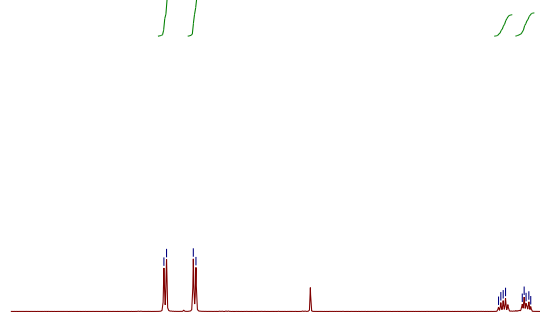

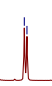

\begin{tabular}{|c|c|c|c|c|c|c|c|c|c|c|c|c|c|c|c|c|c|c|}
\hline & & 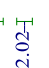 & & & & 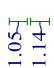 & & 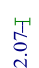 & $\underset{\mathrm{N}}{\mathrm{N}}$ & 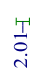 & & & 'ִ & & $\stackrel{5}{6}$ & & & \\
\hline 9.0 & 8.5 & 8.0 & 7.5 & 7.0 & 6.5 & 6.0 & 5.5 & 5.0 & $\begin{array}{c}4.5 \\
\mathrm{f} 1(\mathrm{ppm})\end{array}$ & 4.0 & 3.5 & 3.0 & 2.5 & 2.0 & 1.5 & 1.0 & 0.5 & 0.0 \\
\hline
\end{tabular}

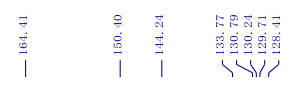
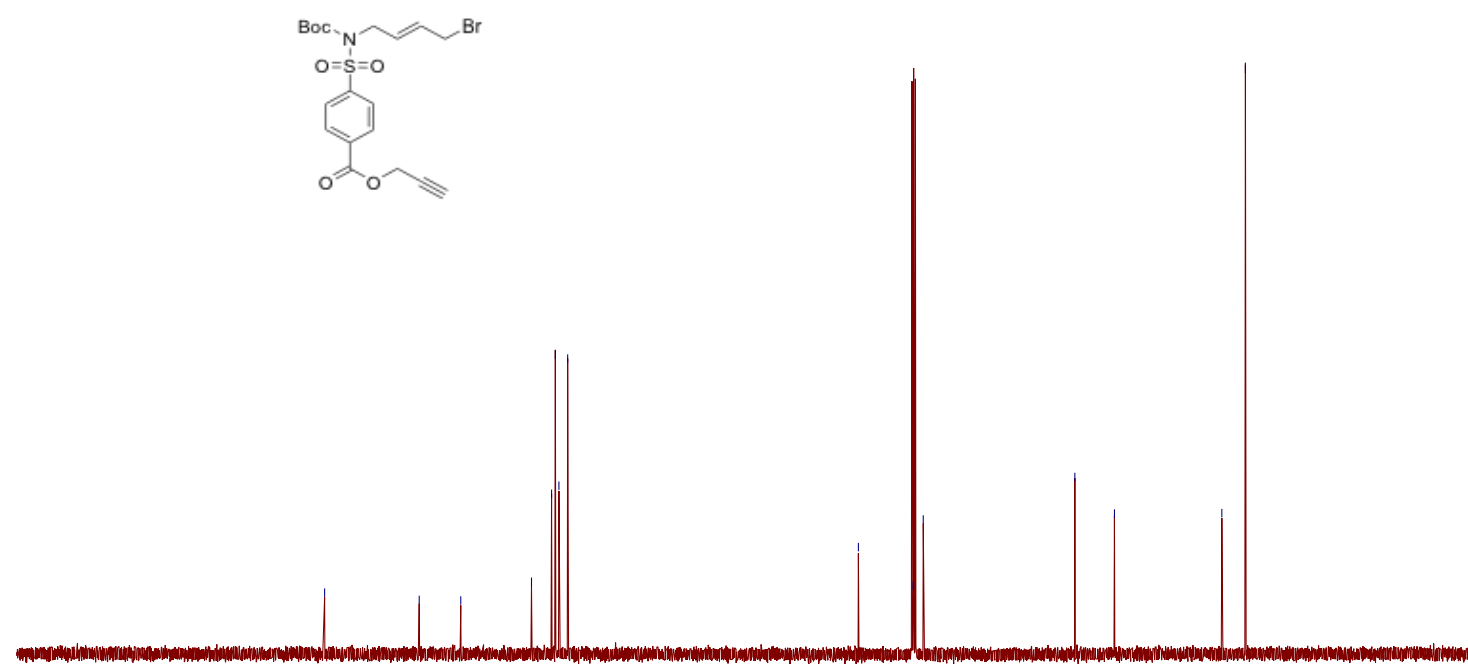

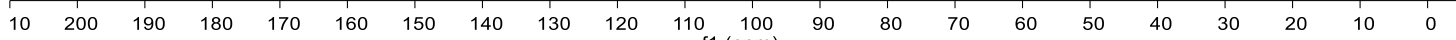




\section{NMR of S10}

Yy
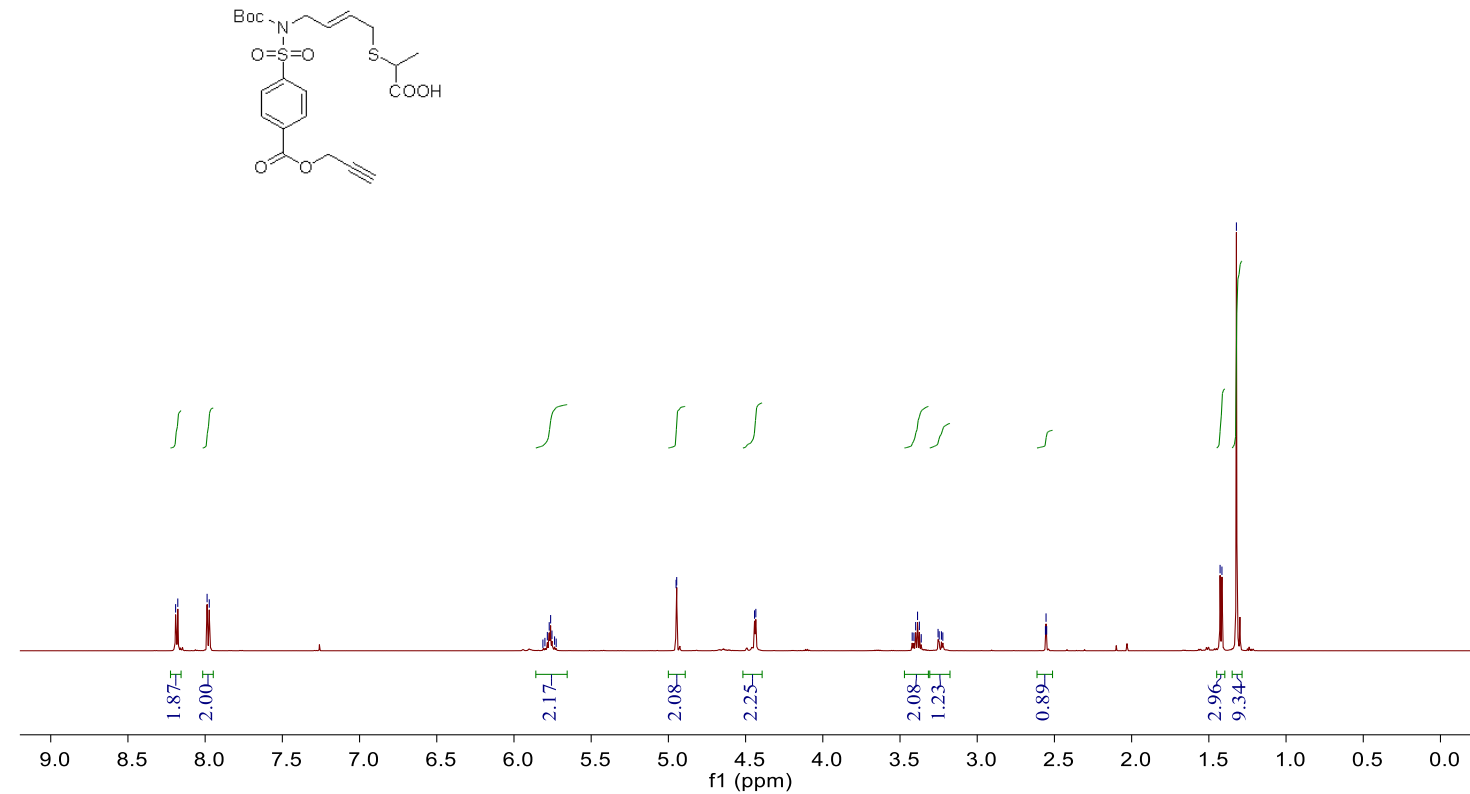

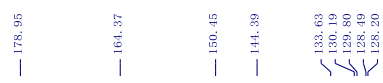
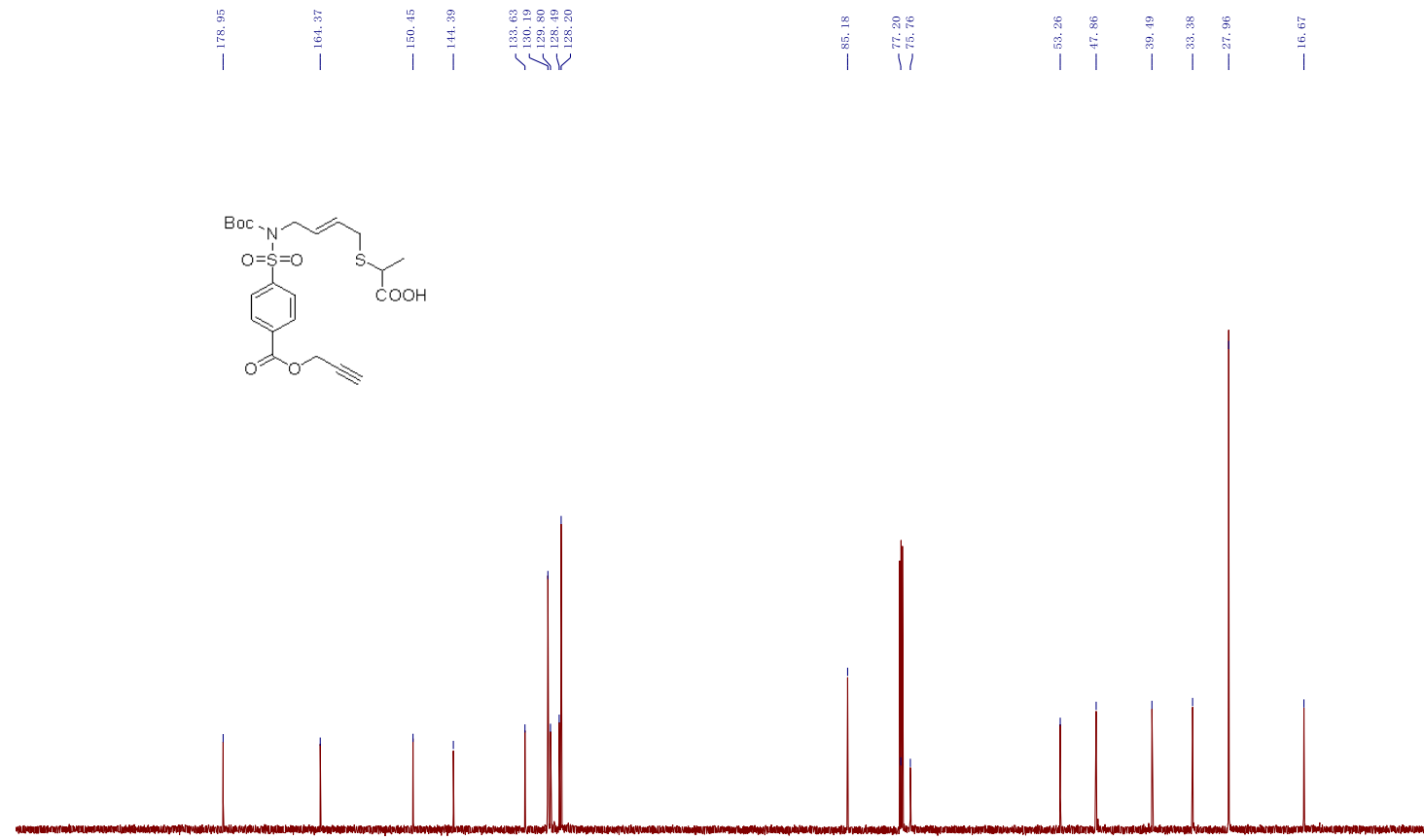

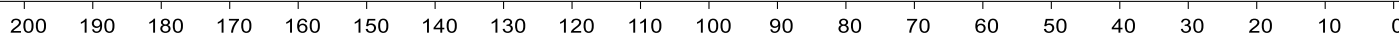
f1 (ppm) 


\section{NMR of S11}

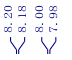
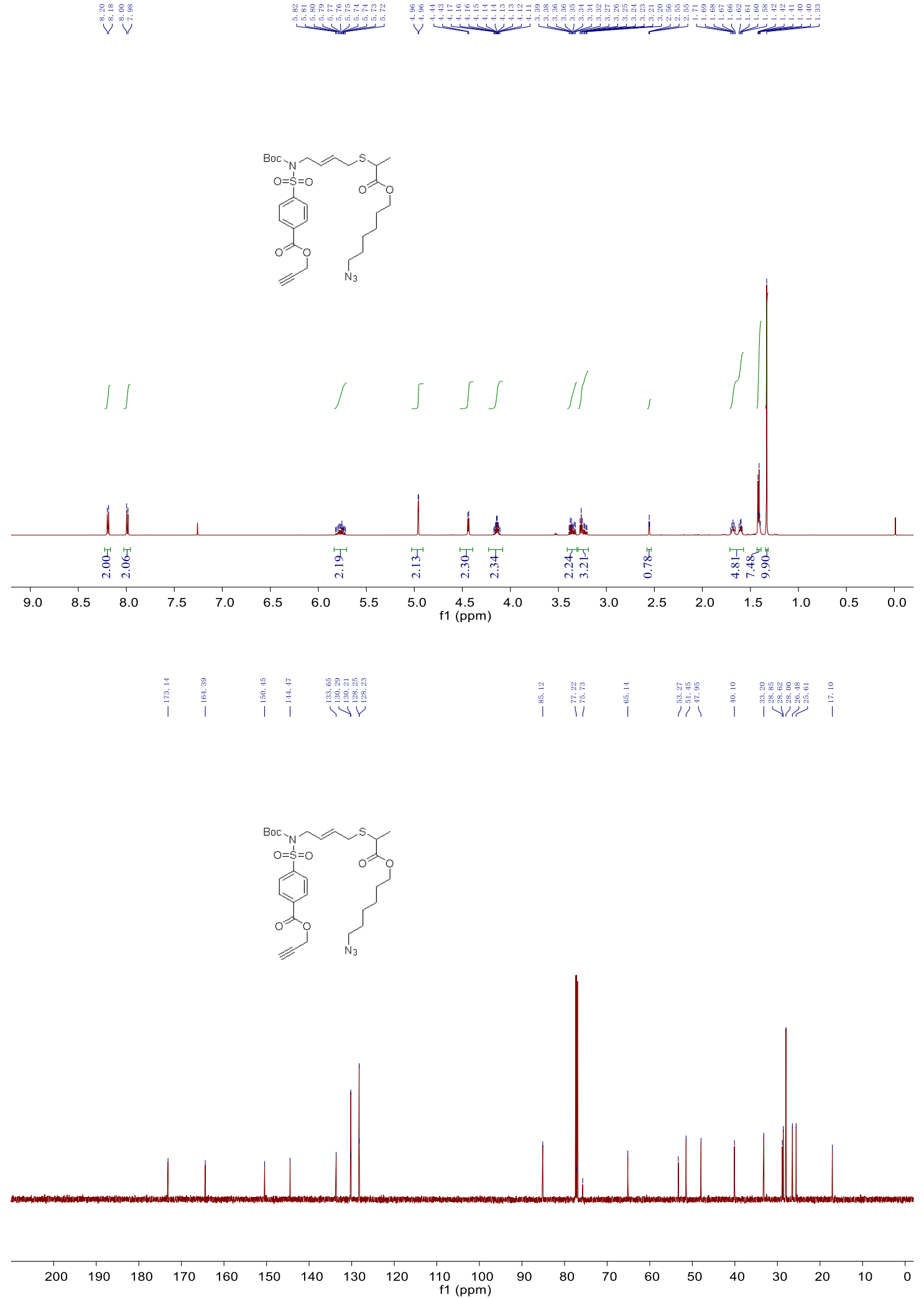

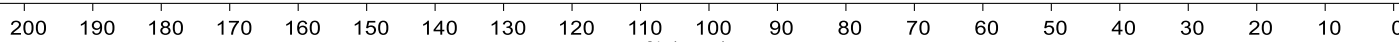




\section{NMR of $\mathbf{S 1 2}$}

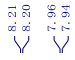
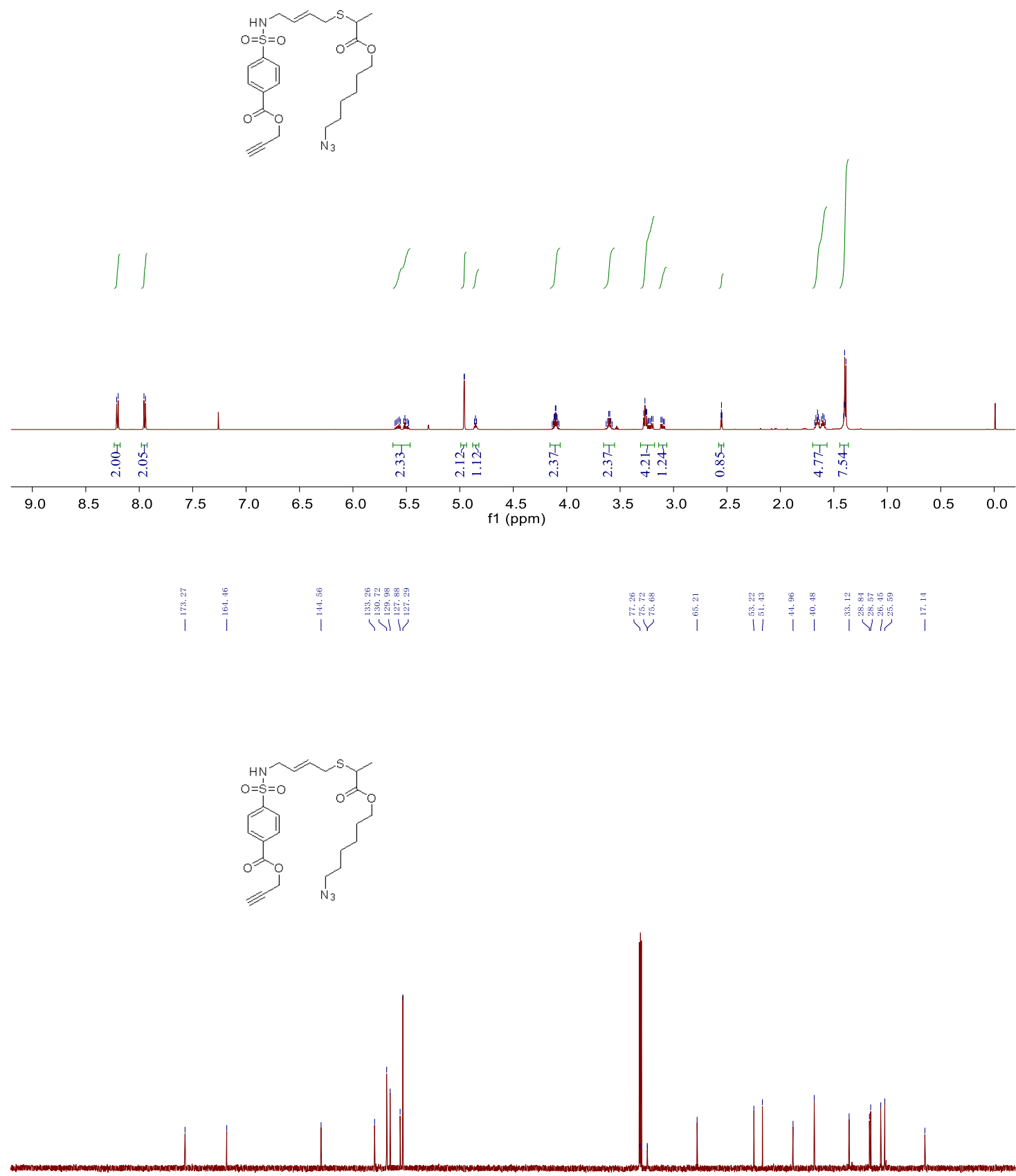

$\begin{array}{llllllllllll}10 & 200 & 190 & 180 & 170 & 160 & 150 & 140 & 130 & 120 & 110 & 100\end{array}$

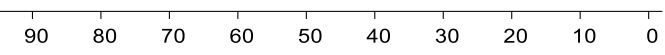


NMR of $\mathbf{S 1 3}$

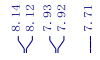
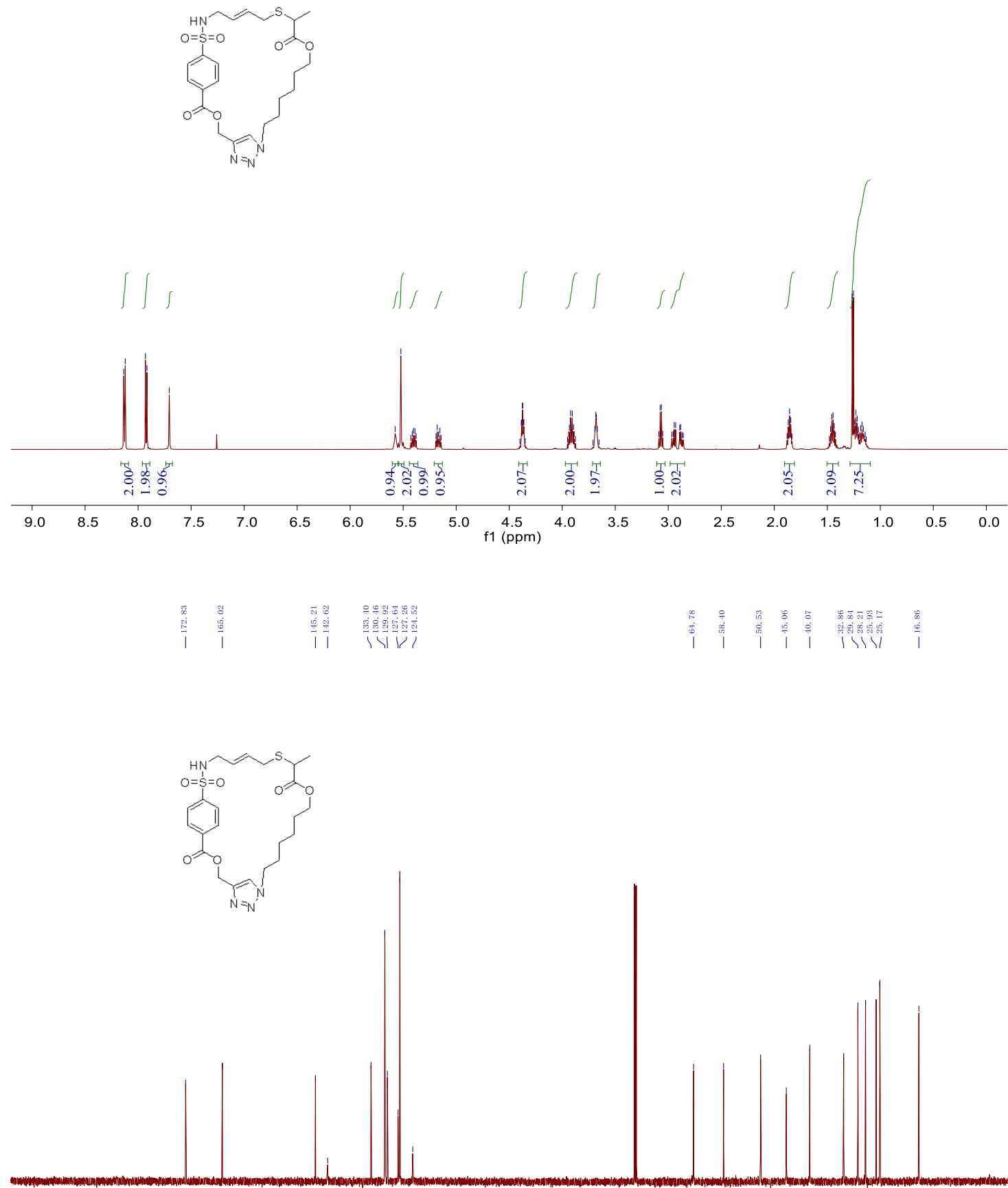

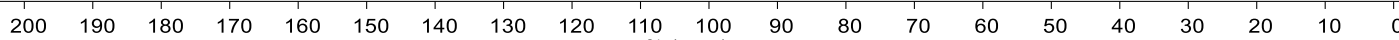




\section{NMR of S14}

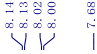
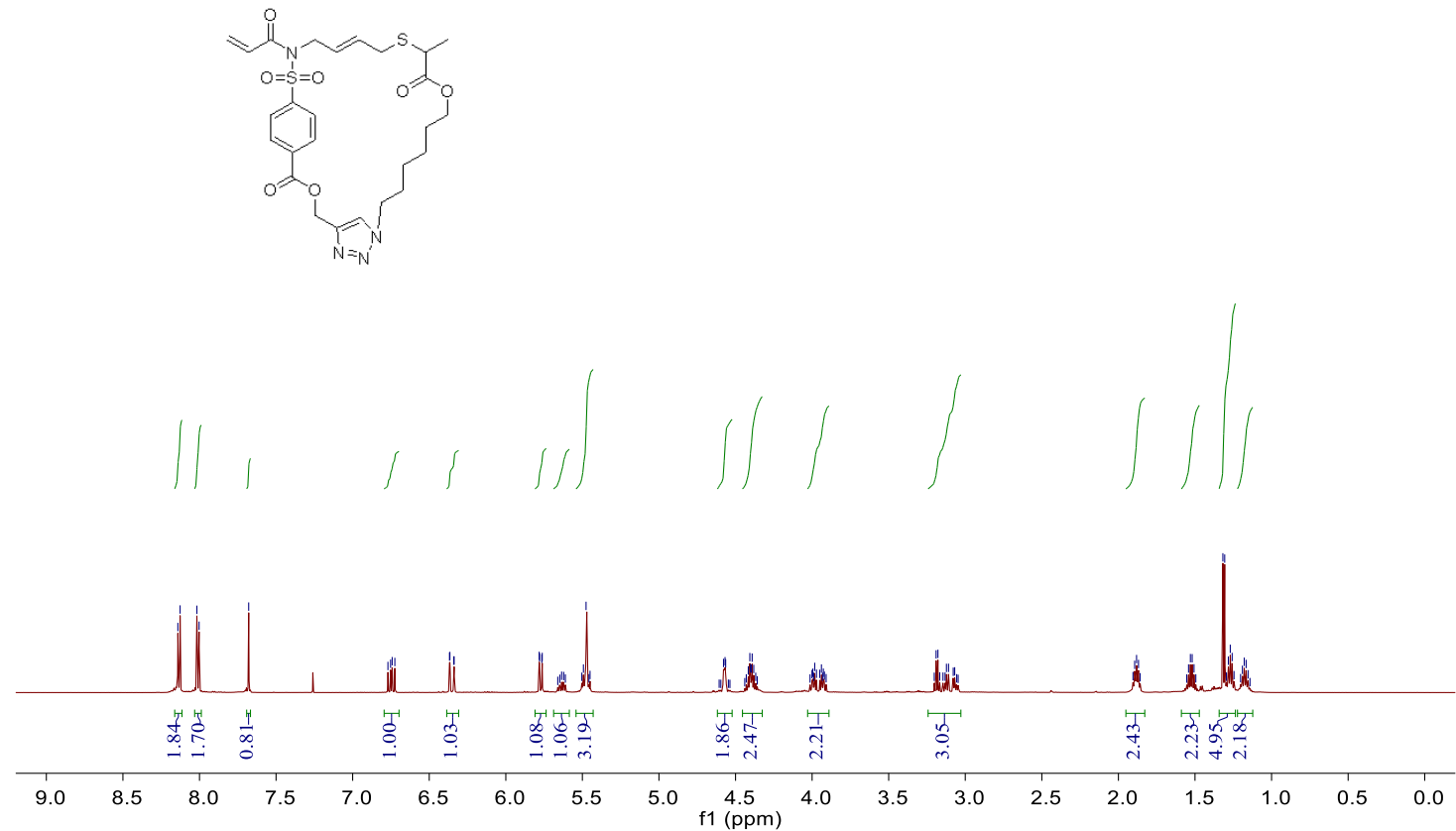

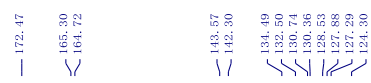
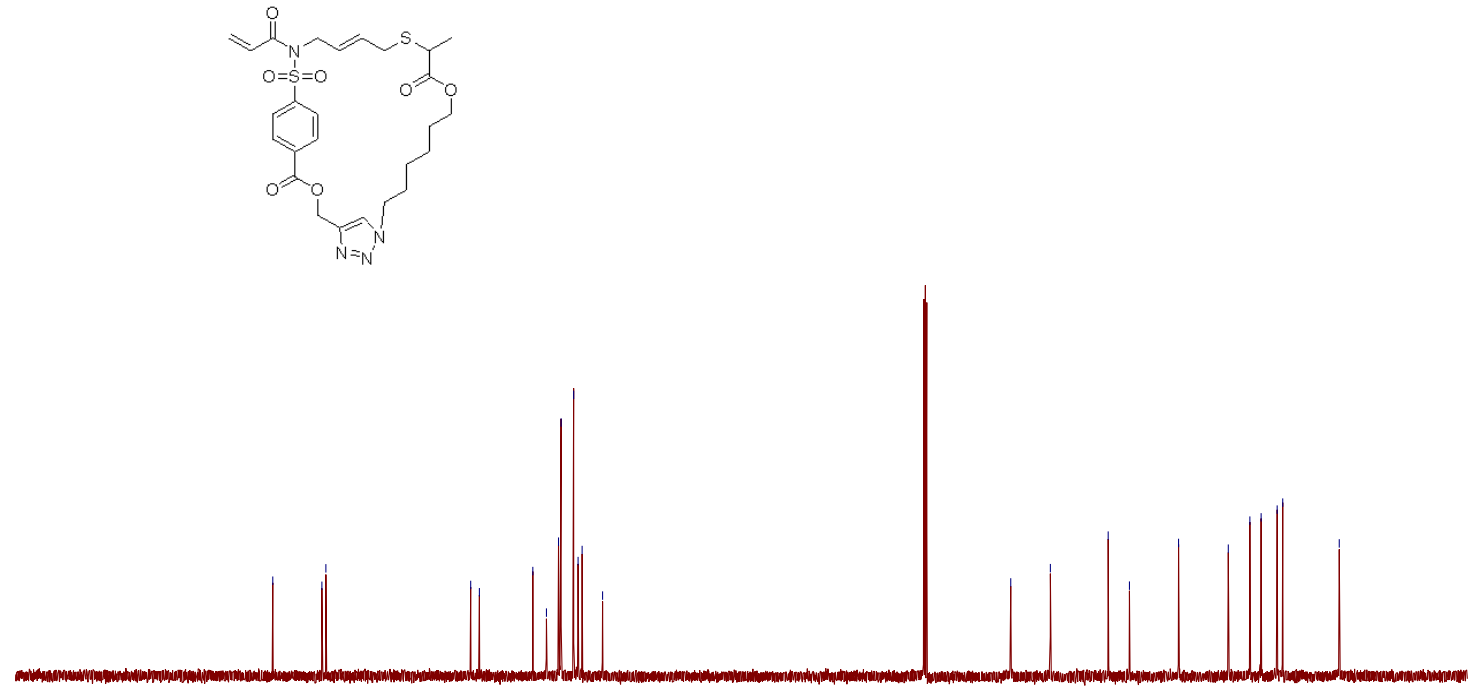

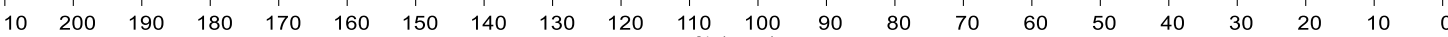
f1 (ppm) 
NMR of $\mathbf{1 2}$

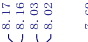

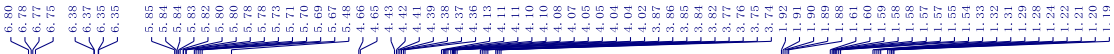
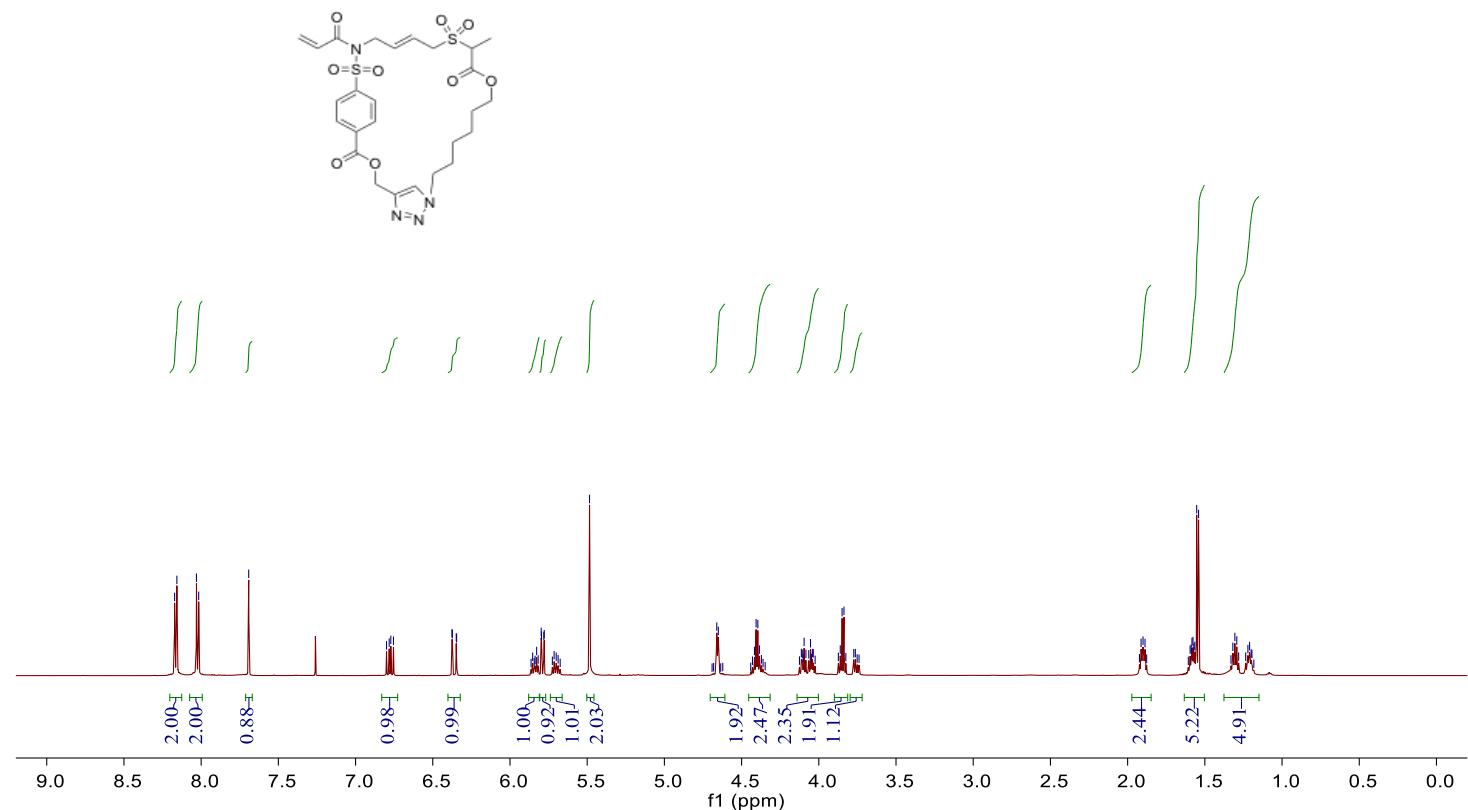

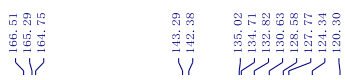

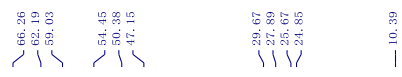
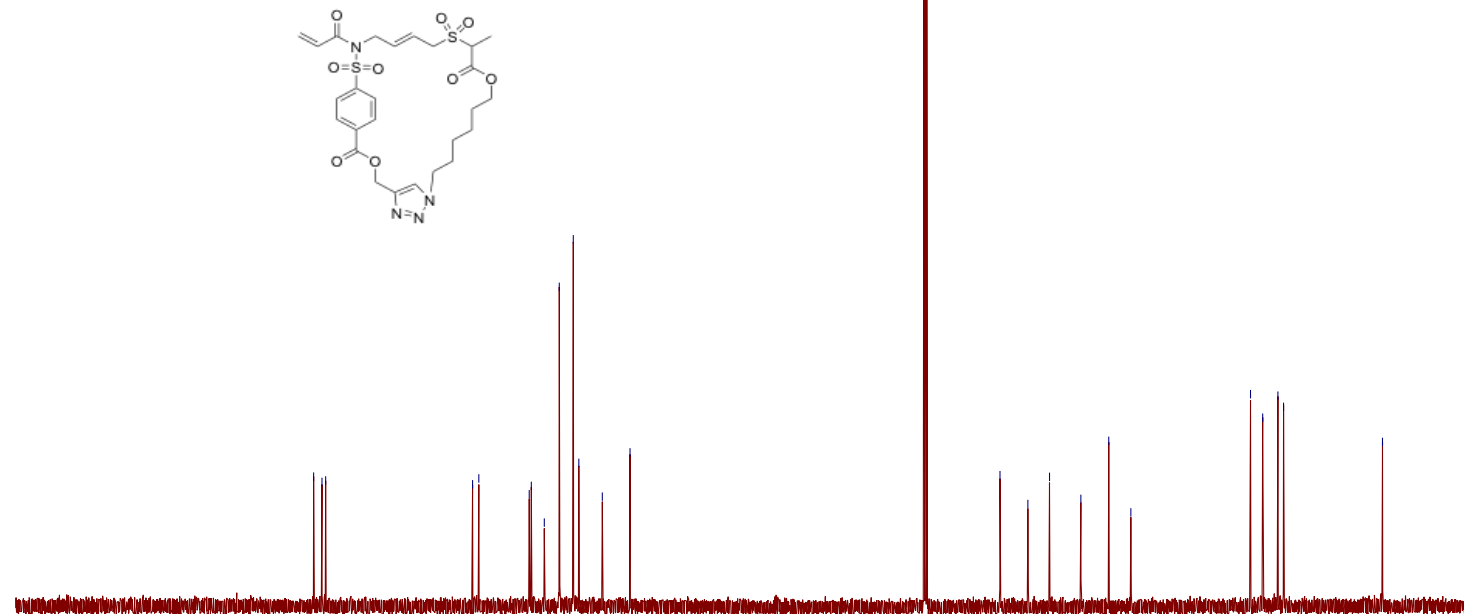

$\begin{array}{lllllllllllllllllllll}200 & 190 & 180 & 170 & 160 & 150 & 140 & 130 & 120 & 110 & 100 & 90 & 80 & 70 & 60 & 50 & 40 & 30 & 20 & 10 & 0\end{array}$ 
NMR of 13

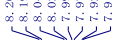

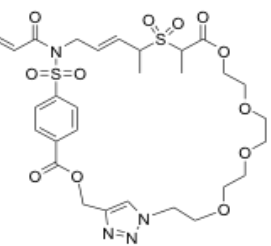

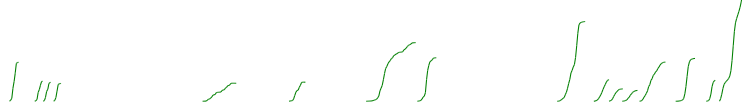

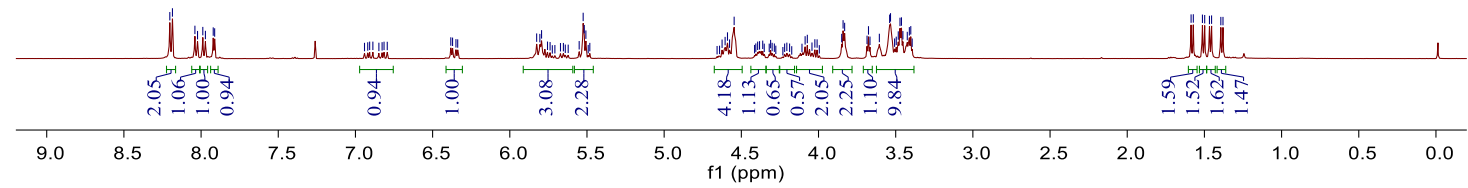
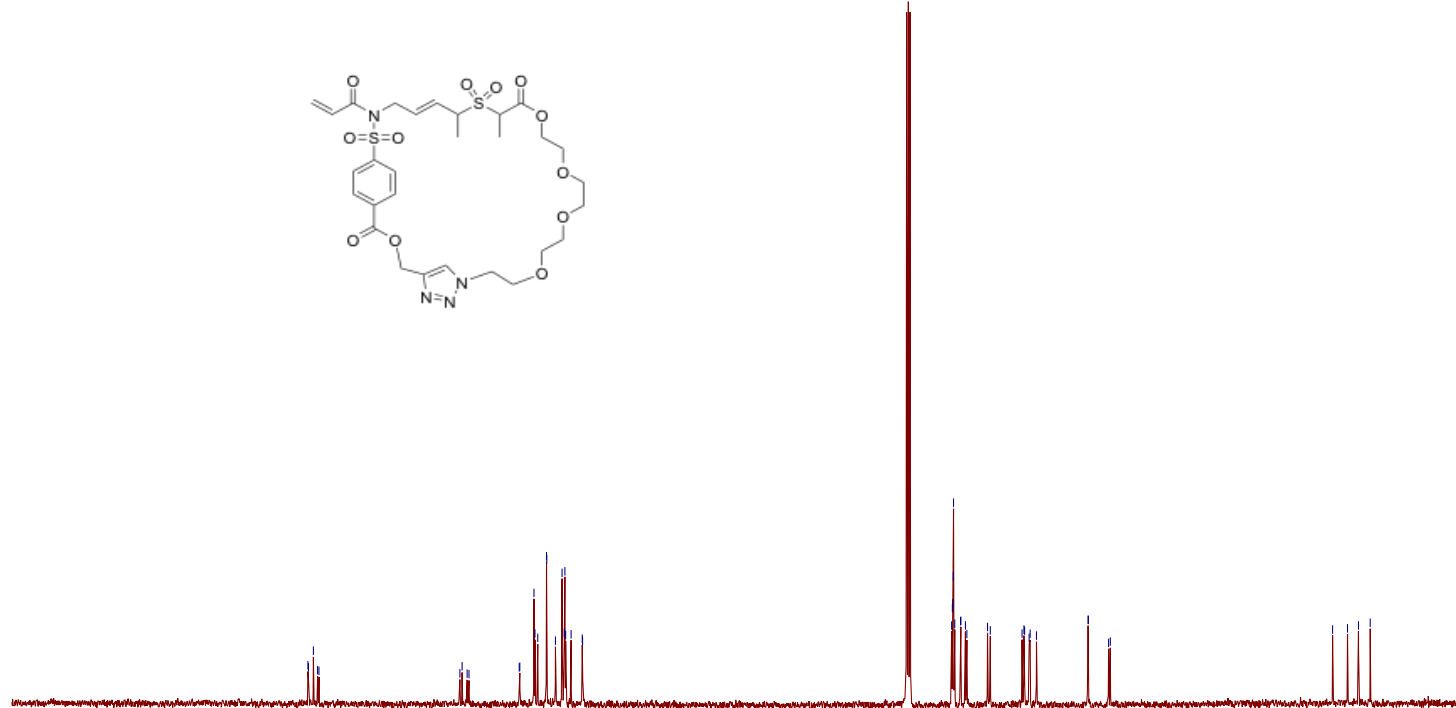

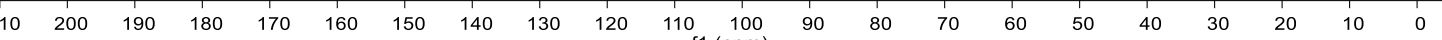


NMR of P-10

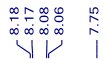
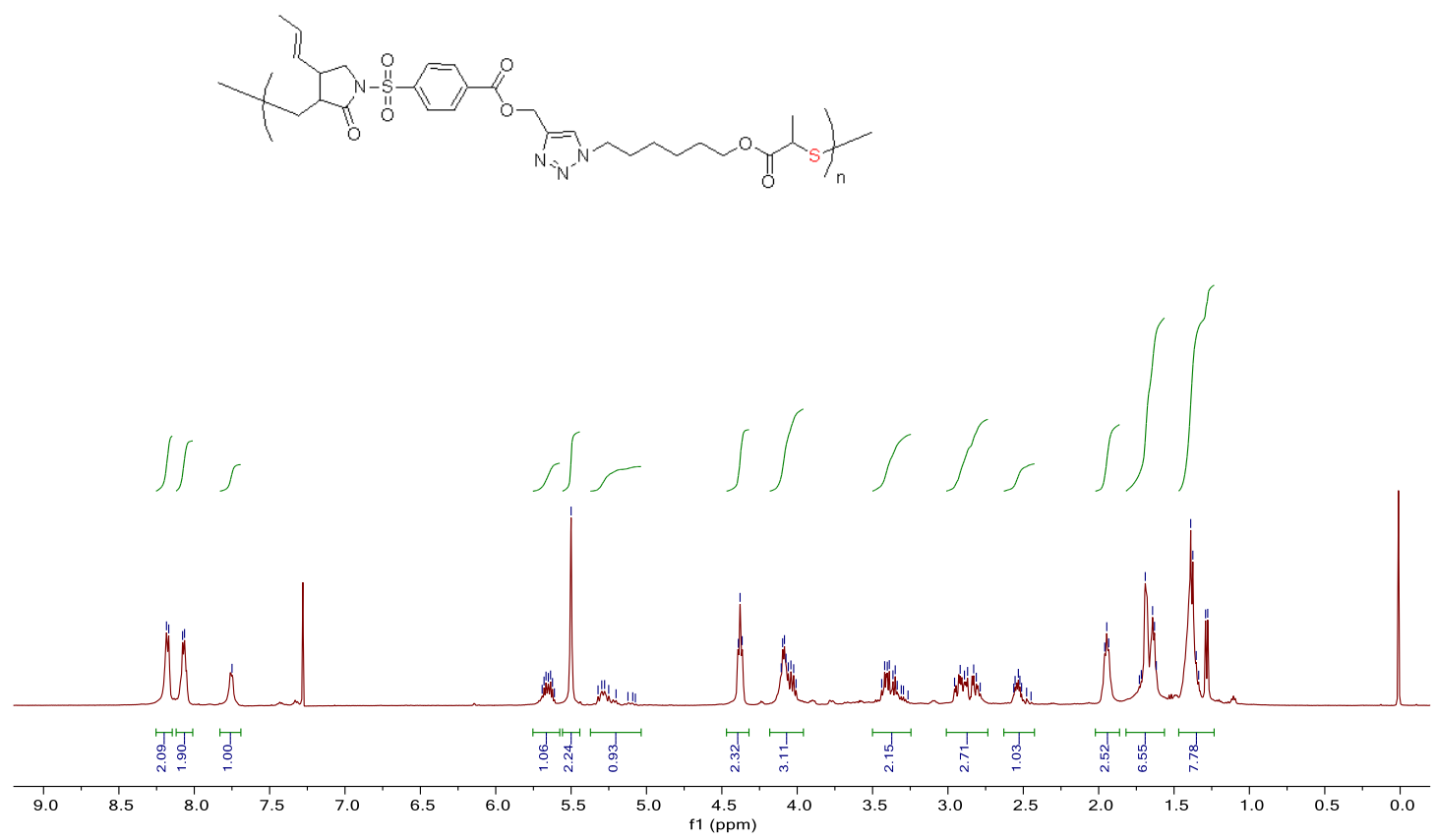

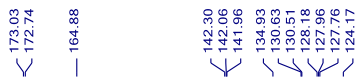

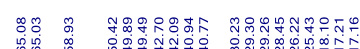

i l
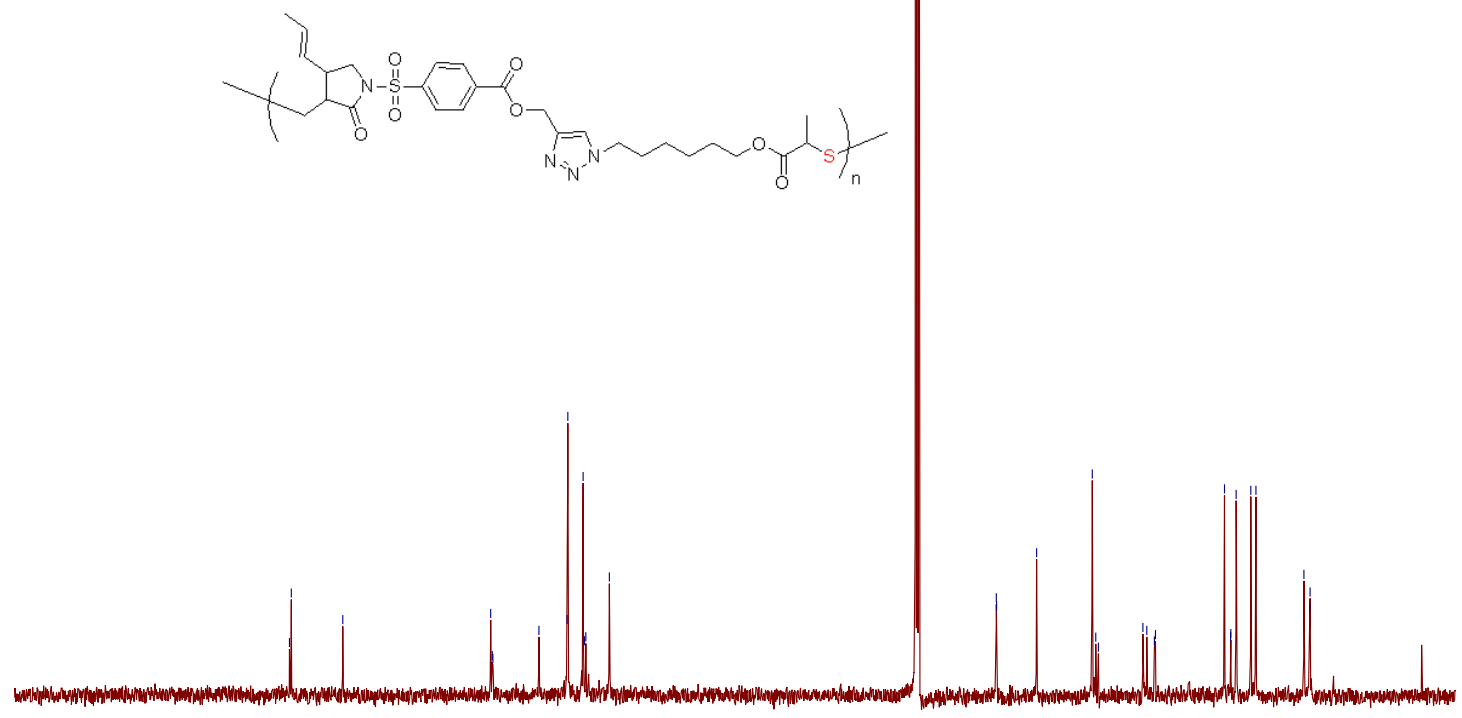

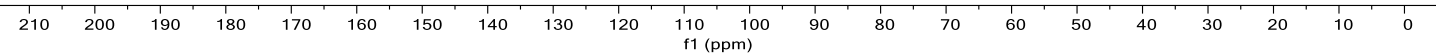




\section{NMR of P-11}

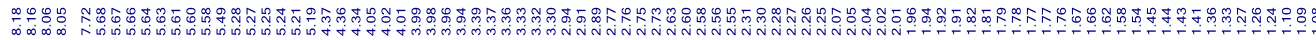

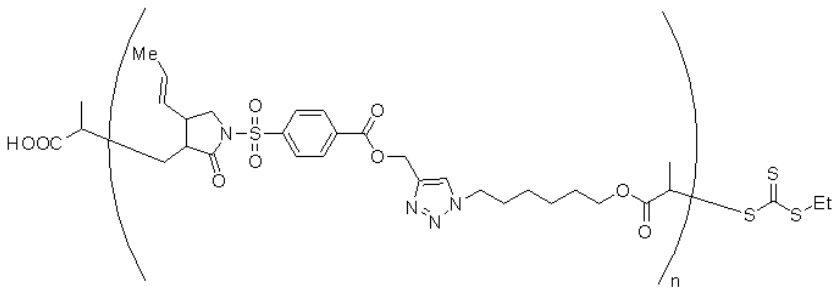
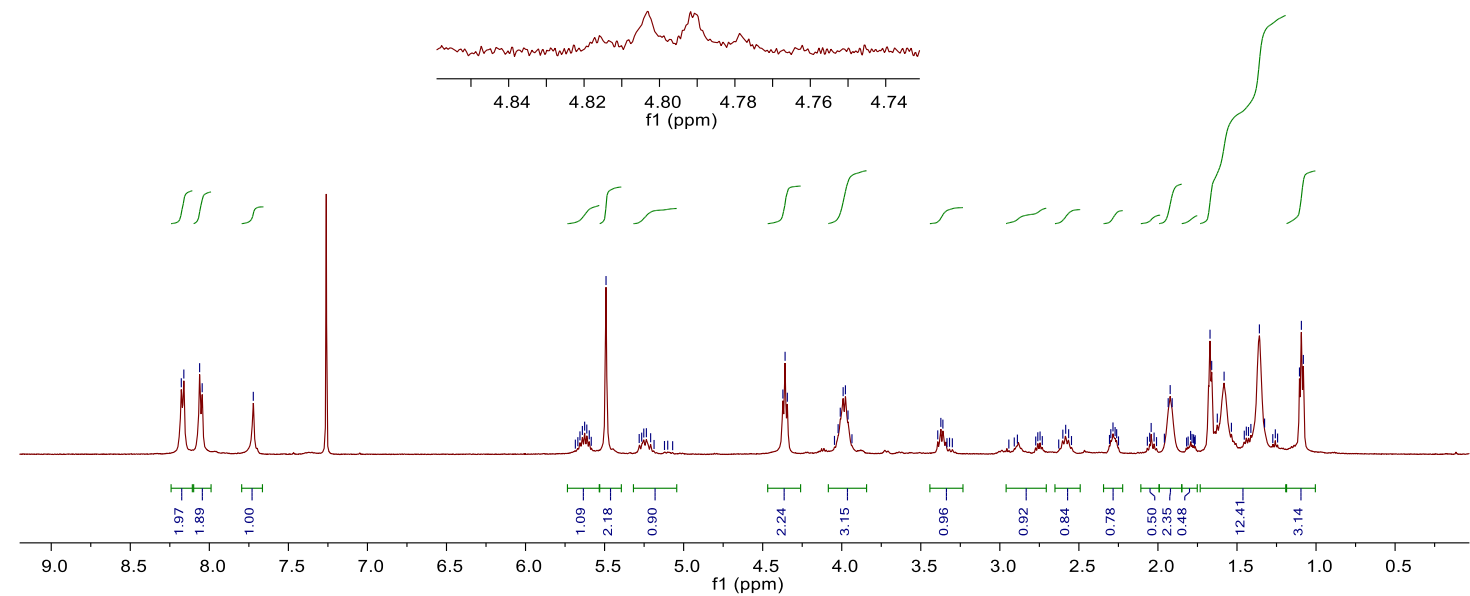

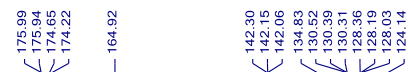

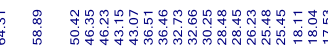

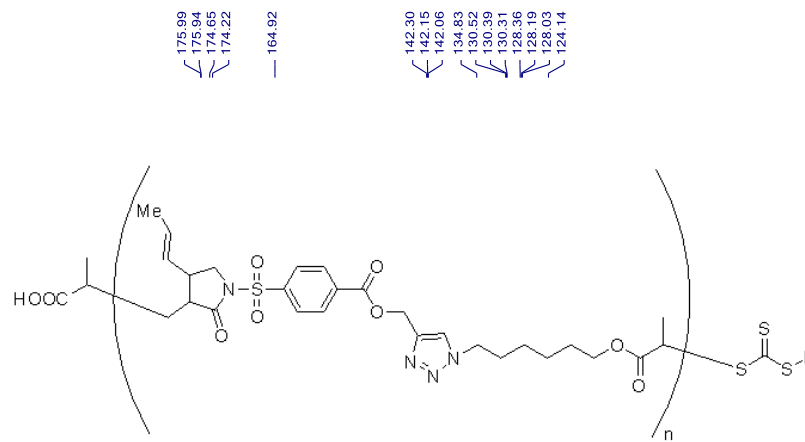

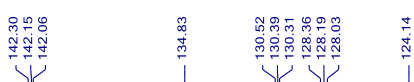
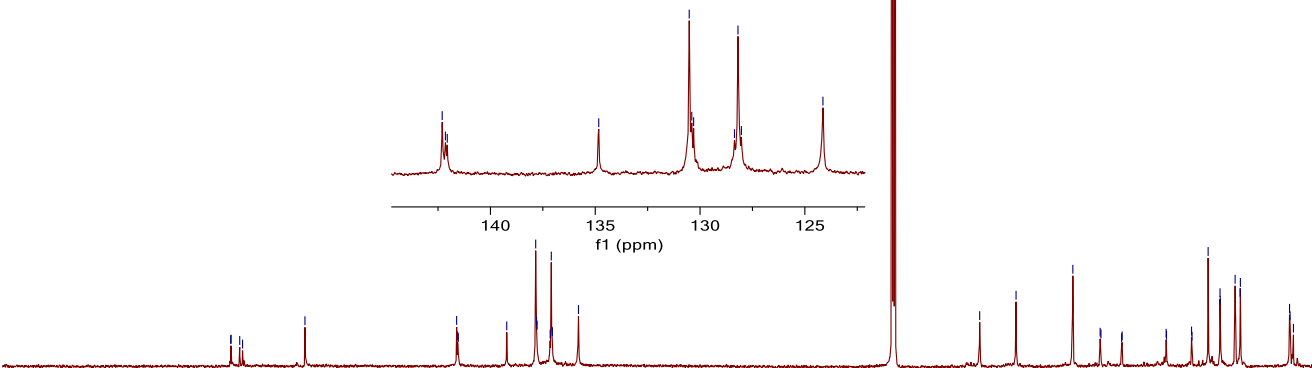

$\begin{array}{lllllllllll}200 & 190 & 180 & 170 & 160 & 150 & 140 & 130 & 120 & 1100 & 100 \\ \mathrm{f} 1(\mathrm{ppm})\end{array}$ 


\section{NMR of P-12}

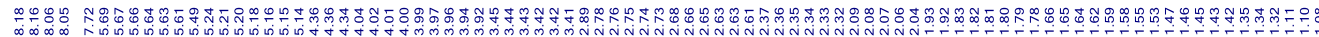

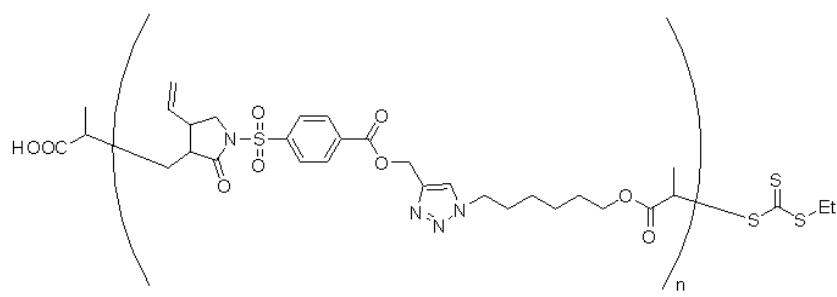
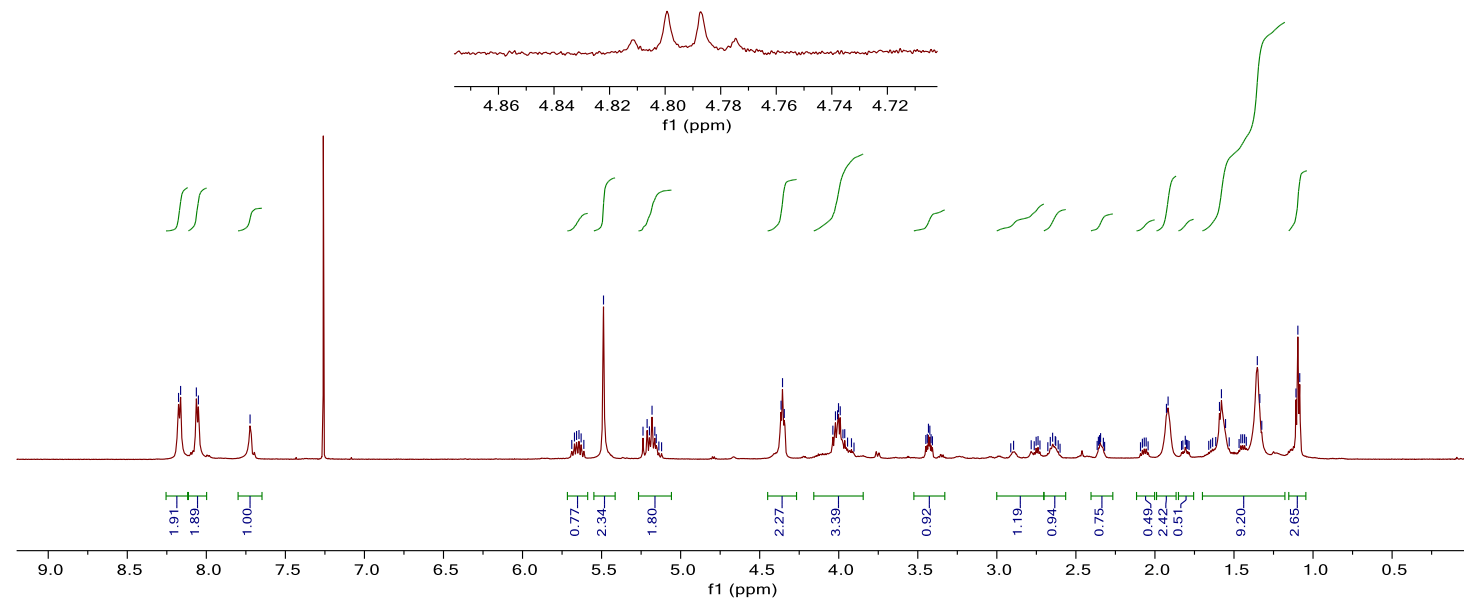

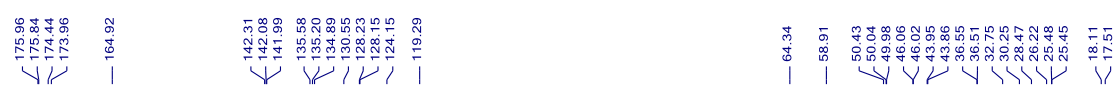

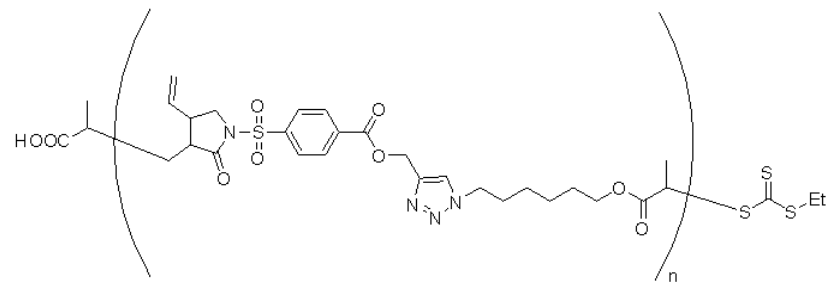

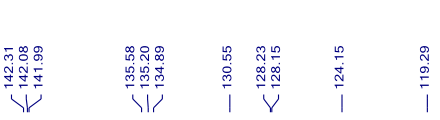
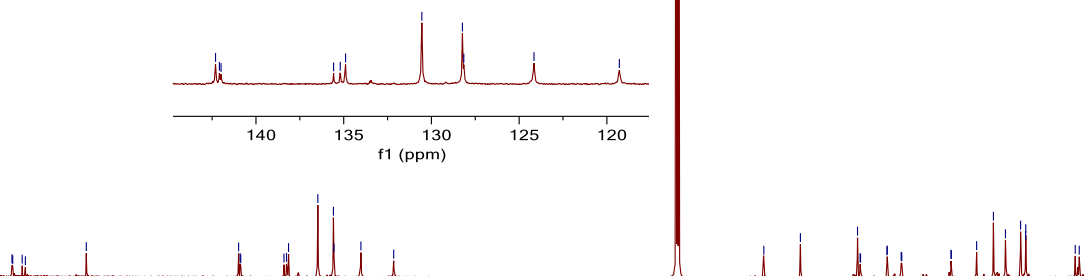

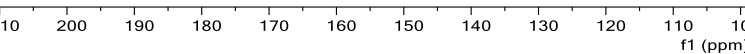




\section{NMR of P-13}

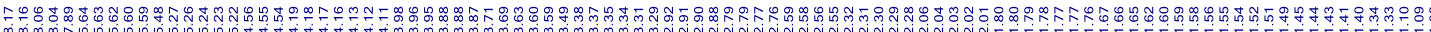
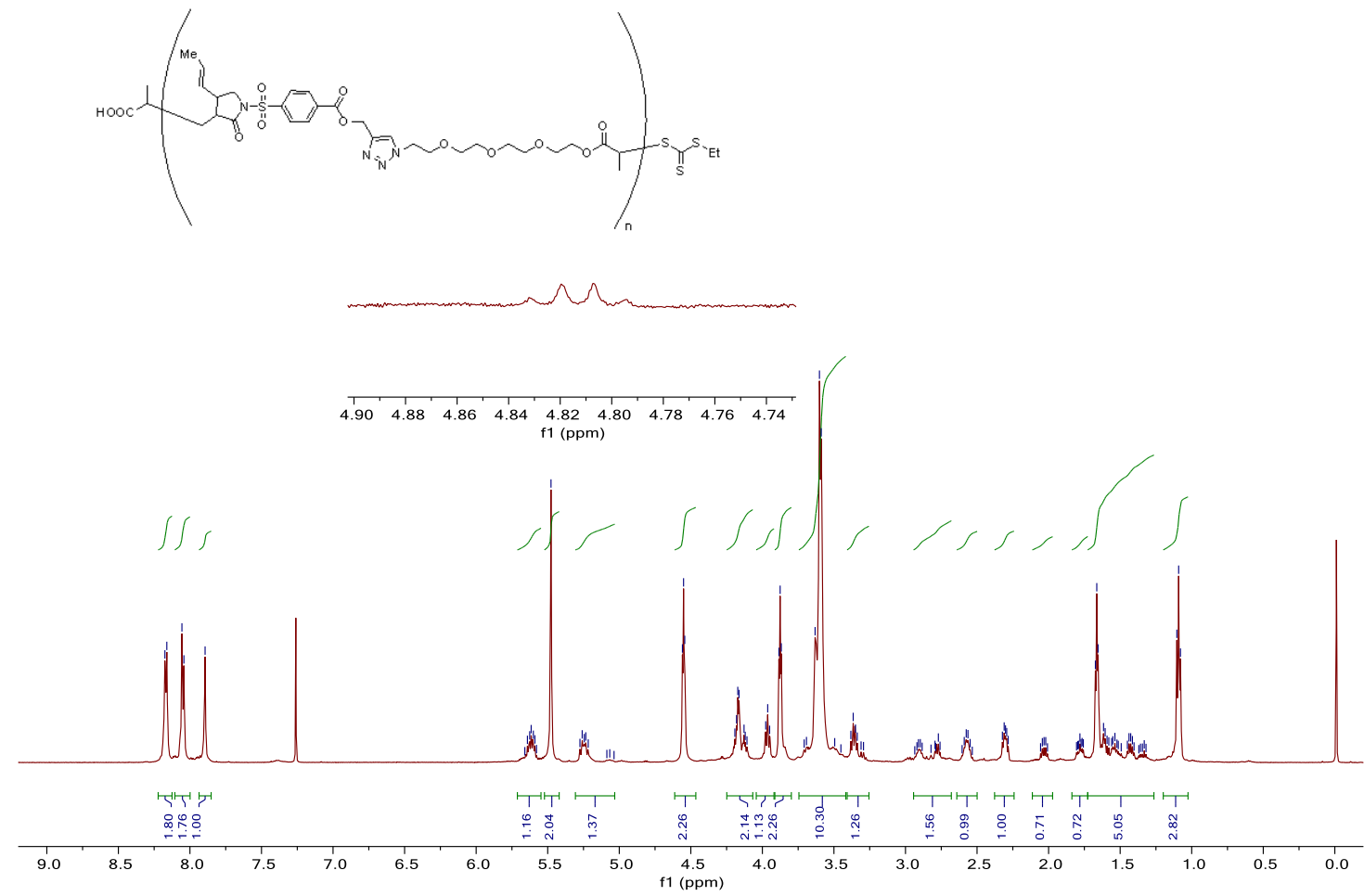

$\underbrace{1 / 1}$

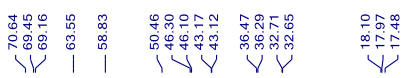

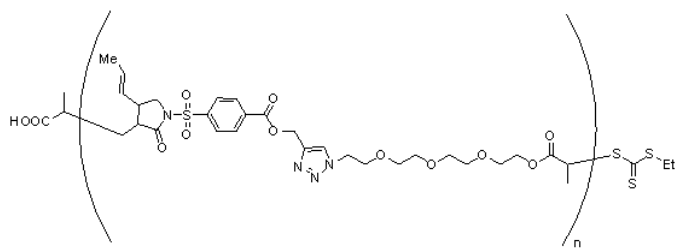

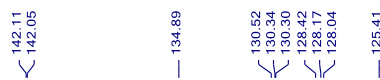
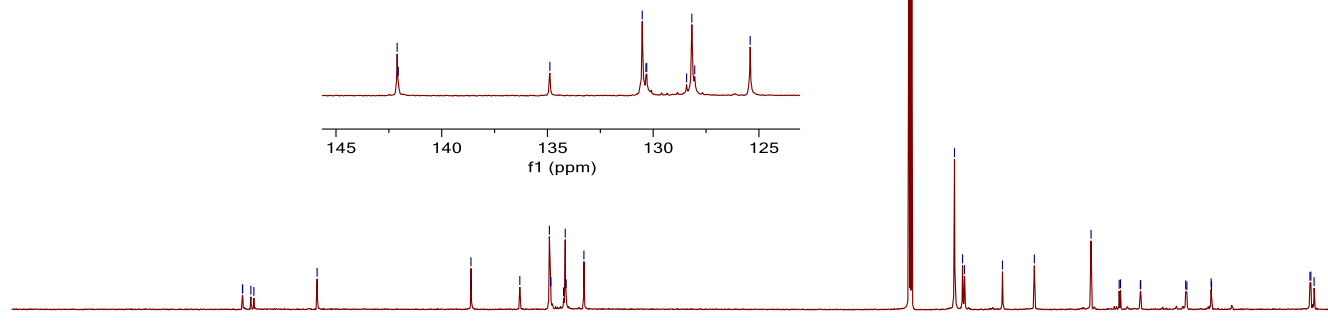

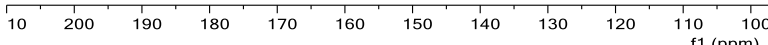


NMR of P-11-b-P-13
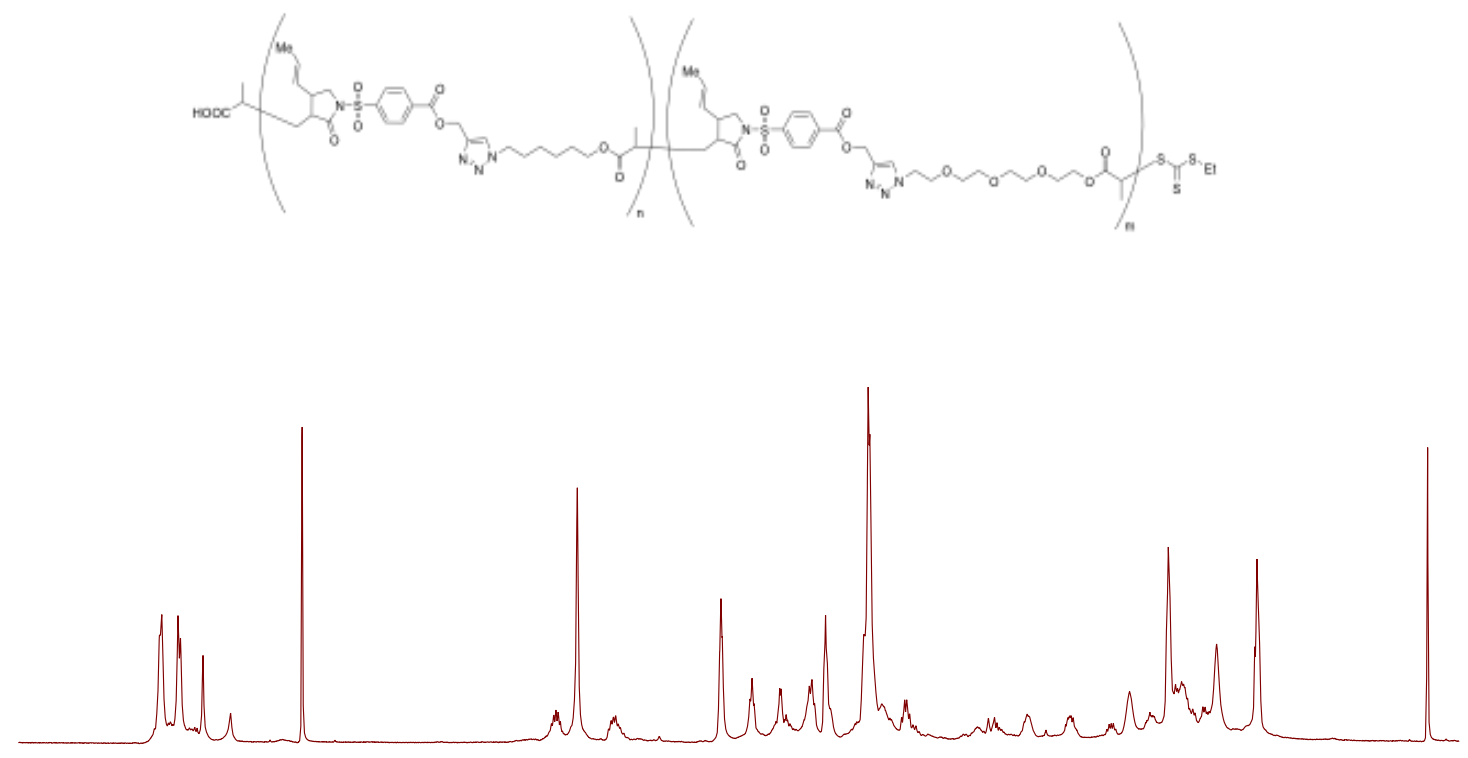

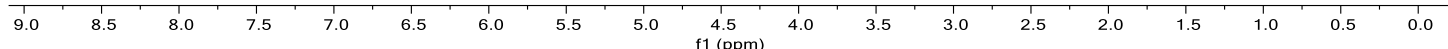


NMR of S15

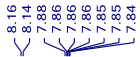

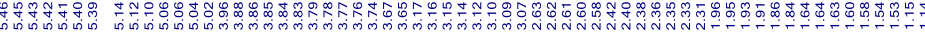

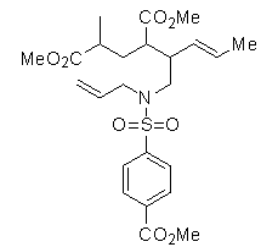

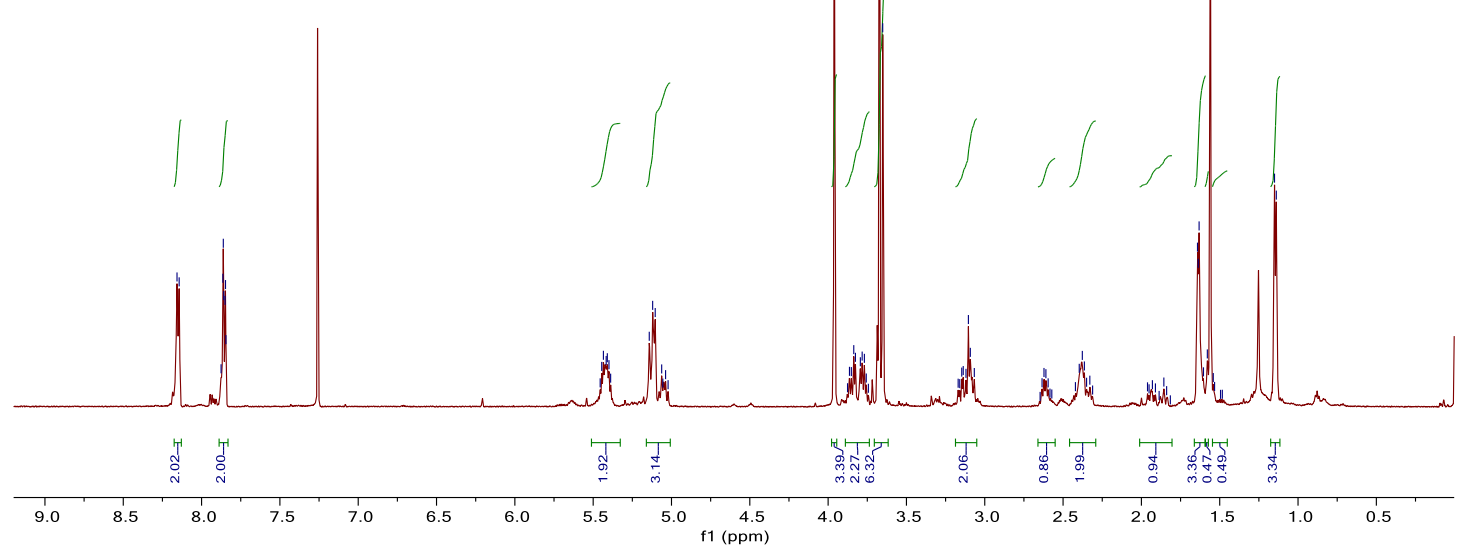

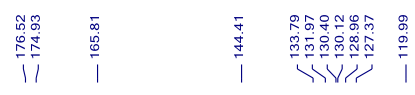

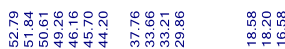

Me

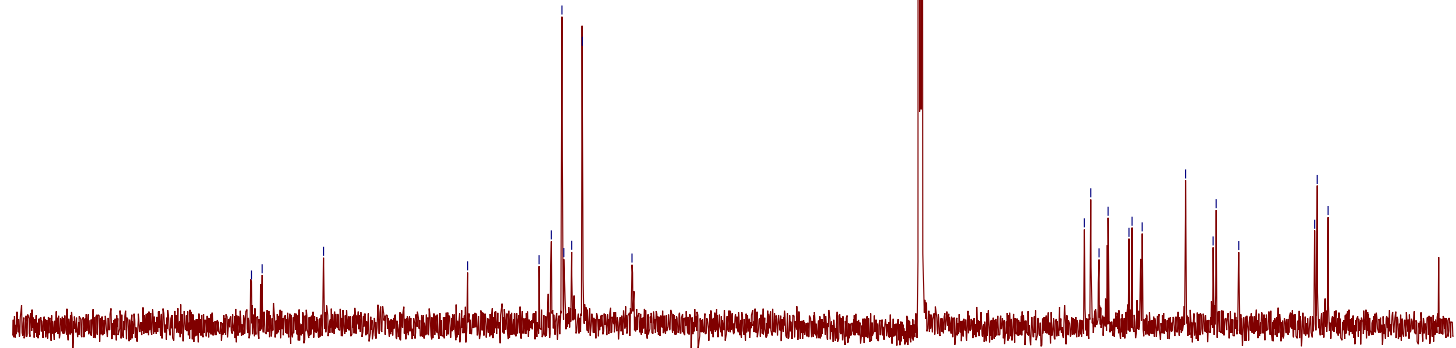

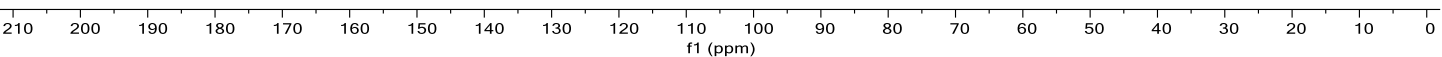




\section{Cartesian coordinates from DFT calculation}

1. Coordinates and Gibbs free energy corrections (Hartree)

\section{G5sm}

Cartesian coordinates (Angstroms):

16

$\begin{array}{llll}\text { C } & 5.316 & -5.765 & 7.357 \\ \text { C } & 5.421 & -6.535 & 6.132 \\ \text { O } & 6.465 & -6.766 & 5.533 \\ \text { O } & 4.205 & -6.981 & 5.712 \\ \text { C } & 4.213 & -7.759 & 4.499 \\ \text { C } & 2.778 & -8.149 & 4.197 \\ \text { H } & 4.855 & -8.635 & 4.641 \\ \text { H } & 4.654 & -7.160 & 3.694 \\ \text { H } & 2.355 & -8.745 & 5.012 \\ \text { H } & 2.739 & -8.745 & 3.278 \\ \text { H } & 2.153 & -7.262 & 4.058 \\ \text { C } & 6.513 & -5.174 & 8.005 \\ \text { H } & 4.329 & -5.632 & 7.790 \\ \text { H } & 7.413 & -5.403 & 7.431 \\ \text { H } & 6.638 & -5.554 & 9.030 \\ \text { H } & 6.417 & -4.081 & 8.095\end{array}$

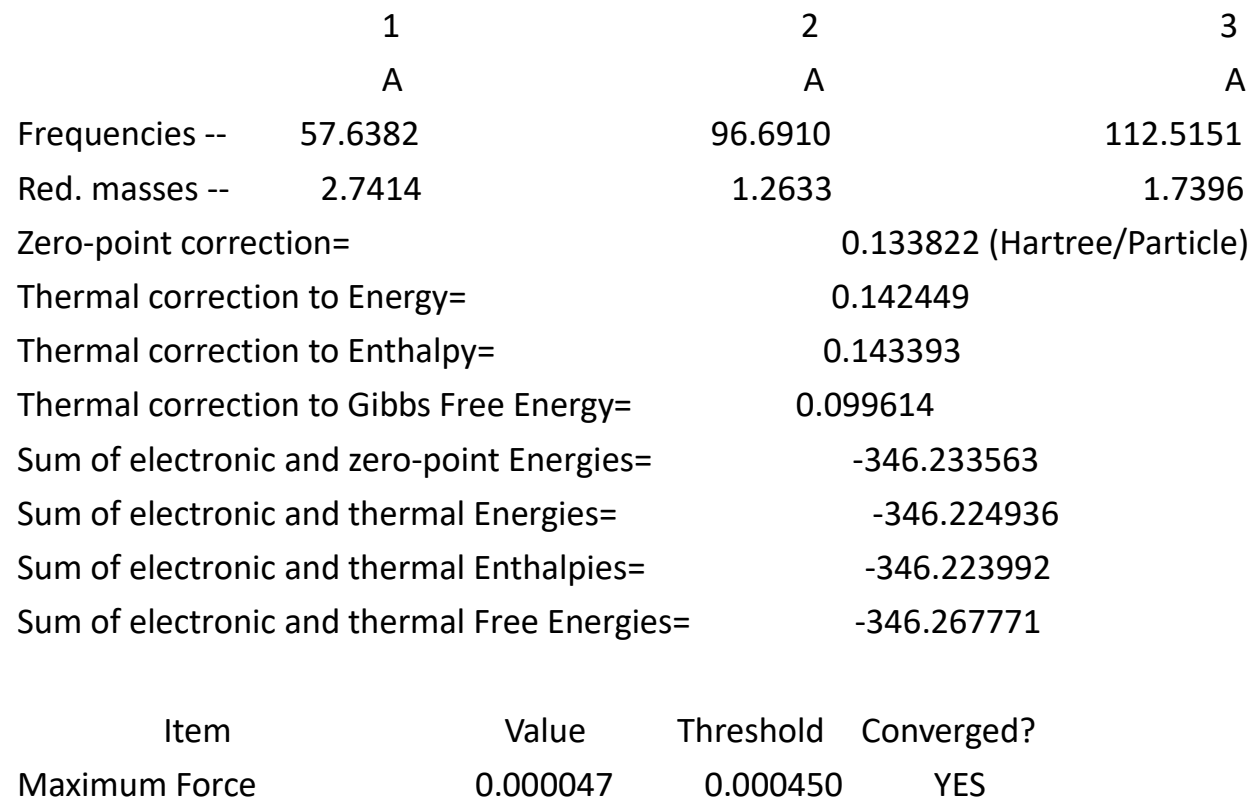


$\begin{array}{llll}\text { RMS Force } & 0.000008 & 0.000300 & \text { YES }\end{array}$

SCF Done: $E(U B 3 L Y P)=-346.367384892$ A.U. after 1 cycles

sm

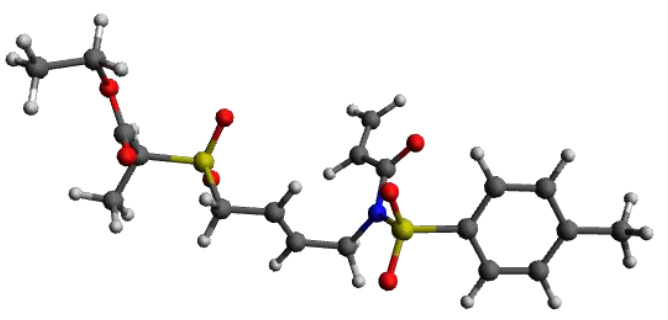

Cartesian coordinates (Angstroms):

54

$\begin{array}{llll}\text { C } & -5.882 & 1.935 & -2.408 \\ \text { C } & -4.767 & 1.968 & -1.673 \\ \text { C } & -4.215 & 0.696 & -1.120 \\ \text { O } & -4.613 & -0.401 & -1.482 \\ \text { N } & -3.210 & 0.809 & -0.147 \\ \text { S } & -2.341 & -0.640 & 0.313 \\ \text { O } & -1.821 & -1.263 & -0.900 \\ \text { O } & -1.435 & -0.172 & 1.368 \\ \text { C } & -3.541 & -1.724 & 1.080 \\ \text { C } & -4.194 & -2.697 & 0.321 \\ \text { C } & -5.078 & -3.562 & 0.959 \\ \text { C } & -5.322 & -3.471 & 2.338 \\ \text { C } & -4.647 & -2.487 & 3.073 \\ \text { C } & -3.752 & -1.615 & 2.456 \\ \text { C } & -6.272 & -4.431 & 3.013 \\ \text { C } & -2.784 & 2.078 & 0.456\end{array}$




\begin{tabular}{lrrr}
$\mathrm{C}$ & -1.772 & 2.864 & -0.336 \\
$\mathrm{C}$ & -1.180 & 2.475 & -1.467 \\
$\mathrm{C}$ & -0.215 & 3.344 & -2.212 \\
$\mathrm{~S}$ & -1.133 & 4.236 & -3.540 \\
$\mathrm{O}$ & -1.974 & 5.265 & -2.900 \\
$\mathrm{O}$ & -1.730 & 3.242 & -4.445 \\
$\mathrm{C}$ & 0.148 & 5.153 & -4.521 \\
$\mathrm{C}$ & 1.023 & 4.151 & -5.259 \\
$\mathrm{C}$ & 0.958 & 6.118 & -3.654 \\
$\mathrm{O}$ & 1.835 & 3.435 & -4.707 \\
$\mathrm{O}$ & 0.782 & 4.172 & -6.575 \\
$\mathrm{C}$ & 1.522 & 3.223 & -7.392 \\
$\mathrm{C}$ & 2.878 & 3.781 & -7.793 \\
$\mathrm{H}$ & -6.396 & 0.996 & -2.589 \\
$\mathrm{H}$ & -6.293 & 2.837 & -2.849 \\
$\mathrm{H}$ & -4.235 & 2.900 & -1.515 \\
$\mathrm{H}$ & -4.017 & -2.758 & -0.745 \\
$\mathrm{H}$ & -5.591 & -4.321 & 0.374 \\
$\mathrm{H}$ & -4.817 & -2.406 & 4.143 \\
$\mathrm{H}$ & -3.212 & -0.873 & 3.033 \\
$\mathrm{H}$ & -7.201 & -4.540 & 2.442 \\
$\mathrm{H}$ & -6.530 & -4.097 & 4.023 \\
$\mathrm{H}$ & -5.826 & -5.431 & 3.098 \\
$\mathrm{H}$ & -2.371 & 1.847 & 1.442 \\
$\mathrm{H}$ & -3.678 & 2.689 & 0.632 \\
$\mathrm{H}$ & -1.529 & 3.837 & 0.092 \\
$\mathrm{H}$ & -1.413 & 1.511 & -1.911 \\
$\mathrm{H}$ & 0.580 & 2.787 & -2.713 \\
$\mathrm{H}$ & 0.221 & 4.120 & -1.577 \\
$\mathrm{H}$ & -0.479 & 5.692 & -5.237 \\
$\mathrm{H}$ & 0.288 & 6.732 & -3.047 \\
$\mathrm{H}$ & 1.546 & 6.783 & -4.296 \\
$\mathrm{H}$ & 1.653 & 5.578 & -3.006 \\
$\mathrm{H}$ & 0.877 & 3.065 & -8.258 \\
$\mathrm{H}$ & 1.620 & 2.289 & -6.834 \\
\hline & 3.769 & 4.740 & -8.310 \\
$\mathrm{H}$ & 3.080 & -8.472 \\
\hline & 3.919 & -6.916
\end{tabular}

\section{1}

A

Frequencies -- $\quad 7.4622$

Red. masses -- $\quad 5.4817$

Zero-point correction=
2

A

13.9128

5.7512

0.427964 (Hartree/Particle)

3

A

14.8050

5.9473

S99 
Thermal correction to Energy=

0.459538

Thermal correction to Enthalpy=

0.460482

Thermal correction to Gibbs Free Energy=

0.358773

Sum of electronic and zero-point Energies=

$-2116.200360$

Sum of electronic and thermal Energies=

$-2116.168786$

Sum of electronic and thermal Enthalpies=

$-2116.167842$

Sum of electronic and thermal Free Energies=

$-2116.269551$

$\begin{array}{ccccc} & \text { Item } & \text { Value } & \text { Threshold } & \text { Converged? } \\ \text { Maximum } & \text { Force } & 0.000009 & 0.000450 & \text { YES } \\ \text { RMS } & \text { Force } & 0.000002 & 0.000300 & \text { YES }\end{array}$

SCF Done: $E(R B 3 L Y P)=-2116.62832426$ A.U. after 3 cycles

TS1

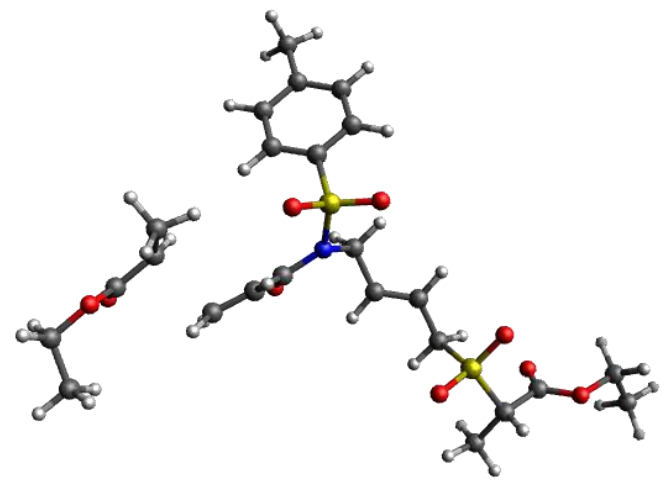

Cartesian coordinates (Angstroms):

70

$\begin{array}{llll}\mathrm{C} & -5.798 & -1.781 & -4.413 \\ \mathrm{H} & -6.223 & -2.795 & -4.345 \\ \mathrm{H} & -5.494 & -1.632 & -5.452 \\ \mathrm{C} & -6.811 & -0.767 & -3.985 \\ \mathrm{C} & -7.927 & -0.349 & -4.839 \\ \mathrm{O} & -7.705 & -0.630 & -6.153\end{array}$




\begin{tabular}{|c|c|c|c|}
\hline & -8.740 & -0.230 & -7.079 \\
\hline $\mathrm{H}$ & -8.618 & -0.907 & -7.929 \\
\hline ᄀ & -9.715 & -0.403 & -6.616 \\
\hline & -8.584 & 1.224 & -7.499 \\
\hline & -9.335 & 1.476 & -8.257 \\
\hline $\mathrm{H}$ & -8.726 & 1.888 & -6.642 \\
\hline 1 & -7.592 & 1.402 & -7.928 \\
\hline & -8.928 & 0.219 & -4.430 \\
\hline & -7.038 & -0.672 & -2.927 \\
\hline $\mathrm{H}$ & -4.910 & -1.751 & -3.774 \\
\hline $\mathcal{L}$ & -5.701 & 1.266 & -4.052 \\
\hline & -4.580 & 1.136 & -3.282 \\
\hline C & -4.610 & 1.541 & -1.868 \\
\hline 0 & -5.526 & 2.198 & -1.384 \\
\hline N & -3.468 & 1.277 & -1.054 \\
\hline S & -2.544 & -0.174 & -1.083 \\
\hline 0 & -2.802 & -0.842 & -2.360 \\
\hline 0 & -1.186 & 0.177 & -0.672 \\
\hline C & -3.270 & -1.171 & 0.222 \\
\hline C & -4.540 & -1.727 & 0.044 \\
\hline C & -5.086 & -2.506 & 1.058 \\
\hline C & -4.381 & -2.749 & 2.249 \\
\hline C & -3.109 & -2.183 & 2.397 \\
\hline C & -2.546 & -1.396 & 1.392 \\
\hline C & -4.977 & -3.618 & 3.329 \\
\hline C & -3.404 & 2.037 & 0.227 \\
\hline C & -3.172 & 3.506 & -0.001 \\
\hline C & -2.099 & 4.159 & 0.453 \\
\hline C & -1.909 & 5.635 & 0.291 \\
\hline$S$ & -0.449 & 5.970 & -0.781 \\
\hline 0 & -0.843 & 5.807 & -2.189 \\
\hline 0 & 0.700 & 5.237 & -0.227 \\
\hline C & -0.082 & 7.776 & -0.556 \\
\hline C & 0.433 & 8.016 & 0.854 \\
\hline C & -1.282 & 8.658 & -0.905 \\
\hline 0 & -0.265 & 7.951 & 1.847 \\
\hline O & 1.739 & 8.310 & 0.851 \\
\hline C & 2.368 & 8.518 & 2.145 \\
\hline C & 2.211 & 9.956 & 2.611 \\
\hline $\mathrm{H}$ & -6.577 & 1.768 & -3.655 \\
\hline $\mathrm{H}$ & -5.631 & 1.159 & -5.130 \\
\hline $\mathrm{H}$ & -3.663 & 0.734 & -3.689 \\
\hline $\mathrm{H}$ & -5.091 & -1.557 & -0.876 \\
\hline $\mathrm{H}$ & -6.075 & -2.936 & 0.925 \\
\hline
\end{tabular}




$\begin{array}{cccc}\mathrm{H} & -2.546 & -2.361 & 3.309 \\ \mathrm{H} & -1.555 & -0.968 & 1.502 \\ \mathrm{H} & -6.039 & -3.396 & 3.481 \\ \mathrm{H} & -4.461 & -3.483 & 4.284 \\ \mathrm{H} & -4.905 & -4.681 & 3.062 \\ \mathrm{H} & -2.584 & 1.624 & 0.815 \\ \mathrm{H} & -4.344 & 1.881 & 0.768 \\ \mathrm{H} & -3.957 & 4.037 & -0.534 \\ \mathrm{H} & -1.306 & 3.628 & 0.974 \\ \mathrm{H} & -1.688 & 6.140 & 1.237 \\ \mathrm{H} & -2.765 & 6.112 & -0.192 \\ \mathrm{H} & 0.733 & 7.916 & -1.273 \\ \mathrm{H} & -1.693 & 8.368 & -1.875 \\ \mathrm{H} & -0.965 & 9.705 & -0.965 \\ \mathrm{H} & -2.061 & 8.587 & -0.140 \\ \mathrm{H} & 3.415 & 8.261 & 1.971 \\ \mathrm{H} & 1.933 & 7.814 & 2.858 \\ \mathrm{H} & 2.608 & 10.654 & 1.866 \\ \mathrm{H} & 2.763 & 10.103 & 3.546 \\ \mathrm{H} & 1.159 & 10.192 & 2.794\end{array}$

\begin{tabular}{|c|c|c|c|c|}
\hline \multicolumn{5}{|c|}{1} \\
\hline \multicolumn{2}{|r|}{ A } & \multicolumn{2}{|l|}{ A } & A \\
\hline \multicolumn{2}{|c|}{ Frequencies -- $\quad-376.2945$} & 6.5869 & & 7.5252 \\
\hline \multicolumn{2}{|c|}{ Red. masses -- $\quad 9.5267$} & 5.5361 & & 5.8819 \\
\hline \multicolumn{3}{|c|}{ Zero-point correction= } & \multicolumn{2}{|c|}{0.563646 (Hartree/Particle) } \\
\hline \multicolumn{3}{|c|}{ Thermal correction to Energy= } & \multicolumn{2}{|c|}{0.604623} \\
\hline \multicolumn{3}{|c|}{ Thermal correction to Enthalpy= } & \multicolumn{2}{|c|}{0.605567} \\
\hline \multicolumn{3}{|c|}{ Thermal correction to Gibbs Free Energy= } & \multicolumn{2}{|c|}{.477765} \\
\hline \multicolumn{3}{|c|}{ Sum of electronic and zero-point Energies= } & \multicolumn{2}{|c|}{-2462.420303} \\
\hline \multicolumn{3}{|c|}{ Sum of electronic and thermal Energies= } & \multicolumn{2}{|c|}{-2462.379326} \\
\hline \multicolumn{3}{|c|}{ Sum of electronic and thermal Enthalpies= } & \multicolumn{2}{|c|}{-2462.378382} \\
\hline \multicolumn{3}{|c|}{ Sum of electronic and thermal Free Energies= } & \multicolumn{2}{|l|}{2462.506183} \\
\hline \multirow{2}{*}{$\begin{array}{c}\text { Item } \\
\text { Maximum Force }\end{array}$} & Value & Threshold & \multicolumn{2}{|c|}{ Converged? } \\
\hline & 0.000017 & 0.000450 & YES & \\
\hline Force & 0.000002 & 0.000300 & YES & \\
\hline
\end{tabular}

G2 


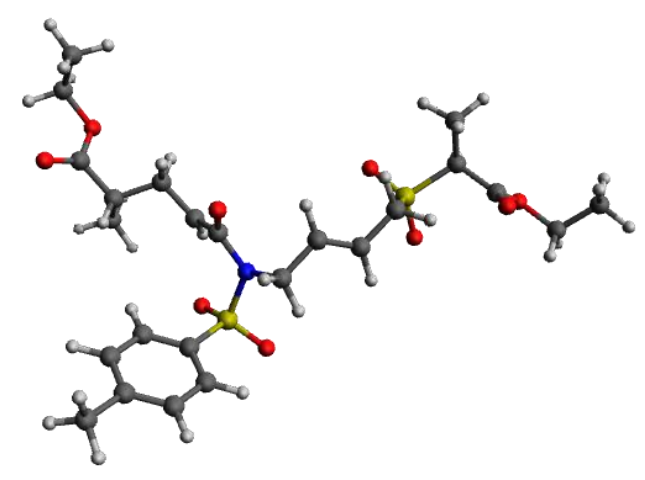

Cartesian coordinates (Angstroms):

70

$\begin{array}{llll}\text { C } & -5.499 & 1.127 & -3.542 \\ \text { C } & -4.283 & 1.073 & -2.687 \\ \text { C } & -4.330 & 1.471 & -1.299 \\ \text { O } & -5.286 & 2.083 & -0.813 \\ \text { N } & -3.165 & 1.258 & -0.490 \\ \text { S } & -2.354 & -0.264 & -0.453 \\ \text { O } & -2.321 & -0.779 & -1.822 \\ \text { O } & -1.125 & -0.044 & 0.308 \\ \text { C } & -3.417 & -1.339 & 0.512 \\ \text { C } & -4.454 & -2.032 & -0.118 \\ \text { C } & -5.286 & -2.846 & 0.645 \\ \text { C } & -5.102 & -2.980 & 2.029 \\ \text { C } & -4.045 & -2.285 & 2.632 \\ \text { C } & -3.201 & -1.464 & 1.886 \\ \text { C } & -6.031 & -3.843 & 2.849 \\ \text { C } & -3.128 & 2.033 & 0.783 \\ \text { C } & -3.028 & 3.514 & 0.529 \\ \text { C } & -1.938 & 4.232 & 0.811 \\ \text { C } & -1.856 & 5.712 & 0.604 \\ \text { S } & -0.722 & 6.089 & -0.799 \\ \text { O } & -1.452 & 5.897 & -2.062\end{array}$




\begin{tabular}{|c|c|c|c|}
\hline o & 0.556 & 5.402 & -0.553 \\
\hline C & -0.376 & 7.909 & -0.673 \\
\hline & 0.477 & 8.172 & 0.557 \\
\hline C & -1.658 & 8.743 & -0.692 \\
\hline O & 0.055 & 8.105 & 1.696 \\
\hline 0 & 1.733 & 8.486 & 0.220 \\
\hline c & 2.668 & 8.715 & 1.309 \\
\hline C & 2.616 & 10.158 & 1.786 \\
\hline $\mathrm{H}$ & -6.293 & 1.656 & -3.007 \\
\hline $\mathrm{H}$ & -5.277 & 1.686 & -4.460 \\
\hline $\mathrm{H}$ & -3.338 & 0.754 & -3.103 \\
\hline $\mathrm{H}$ & -4.588 & -1.954 & -1.192 \\
\hline $\mathrm{H}$ & -6.089 & -3.392 & 0.155 \\
\hline $\mathrm{H}$ & -3.874 & -2.393 & 3.700 \\
\hline $\mathrm{H}$ & -2.370 & -0.948 & 2.353 \\
\hline $\mathrm{H}$ & -6.935 & -3.287 & 3.130 \\
\hline $\mathrm{H}$ & -5.554 & -4.181 & 3.774 \\
\hline $\mathrm{H}$ & -6.355 & -4.727 & 2.289 \\
\hline $\mathrm{H}$ & -2.248 & 1.696 & 1.331 \\
\hline $\mathrm{H}$ & -4.029 & 1.810 & 1.367 \\
\hline $\mathrm{H}$ & -3.913 & 3.993 & 0.118 \\
\hline $\mathrm{H}$ & -1.043 & 3.751 & 1.201 \\
\hline $\mathrm{H}$ & -1.433 & 6.239 & 1.466 \\
\hline $\mathrm{H}$ & -2.823 & 6.147 & 0.341 \\
\hline $\mathrm{H}$ & 0.219 & 8.075 & -1.576 \\
\hline $\mathrm{H}$ & -2.295 & 8.440 & -1.527 \\
\hline $\mathrm{H}$ & -1.407 & 9.801 & -0.819 \\
\hline $\mathrm{H}$ & -2.210 & 8.639 & 0.247 \\
\hline $\mathrm{H}$ & 3.640 & 8.466 & 0.877 \\
\hline $\mathrm{H}$ & 2.438 & 8.015 & 2.116 \\
\hline $\mathrm{H}$ & 2.804 & 10.849 & 0.959 \\
\hline $\mathrm{H}$ & 3.383 & 10.321 & 2.551 \\
\hline $\mathrm{H}$ & 1.641 & 10.385 & 2.226 \\
\hline C & -6.005 & -0.289 & -3.961 \\
\hline C & -4.972 & -1.073 & -4.792 \\
\hline C & -7.323 & -0.178 & -4.716 \\
\hline 0 & -8.346 & -0.749 & -4.404 \\
\hline O & -7.205 & 0.622 & -5.801 \\
\hline C & -8.391 & 0.798 & -6.614 \\
\hline C & -9.276 & 1.908 & -6.068 \\
\hline $\mathrm{H}$ & -6.246 & -0.856 & -3.055 \\
\hline $\mathrm{H}$ & -4.696 & -0.519 & -5.695 \\
\hline $\mathrm{H}$ & -5.378 & -2.044 & -5.098 \\
\hline $\mathrm{H}$ & -4.066 & -1.259 & -4.207 \\
\hline
\end{tabular}




$\begin{array}{rrrr}\mathrm{H} & -8.928 & -0.152 & -6.661 \\ \mathrm{H} & -8.002 & 1.046 & -7.606 \\ \mathrm{H} & -9.668 & 1.637 & -5.083 \\ \mathrm{H} & -10.125 & 2.071 & -6.742 \\ \mathrm{H} & -8.719 & 2.846 & -5.983\end{array}$

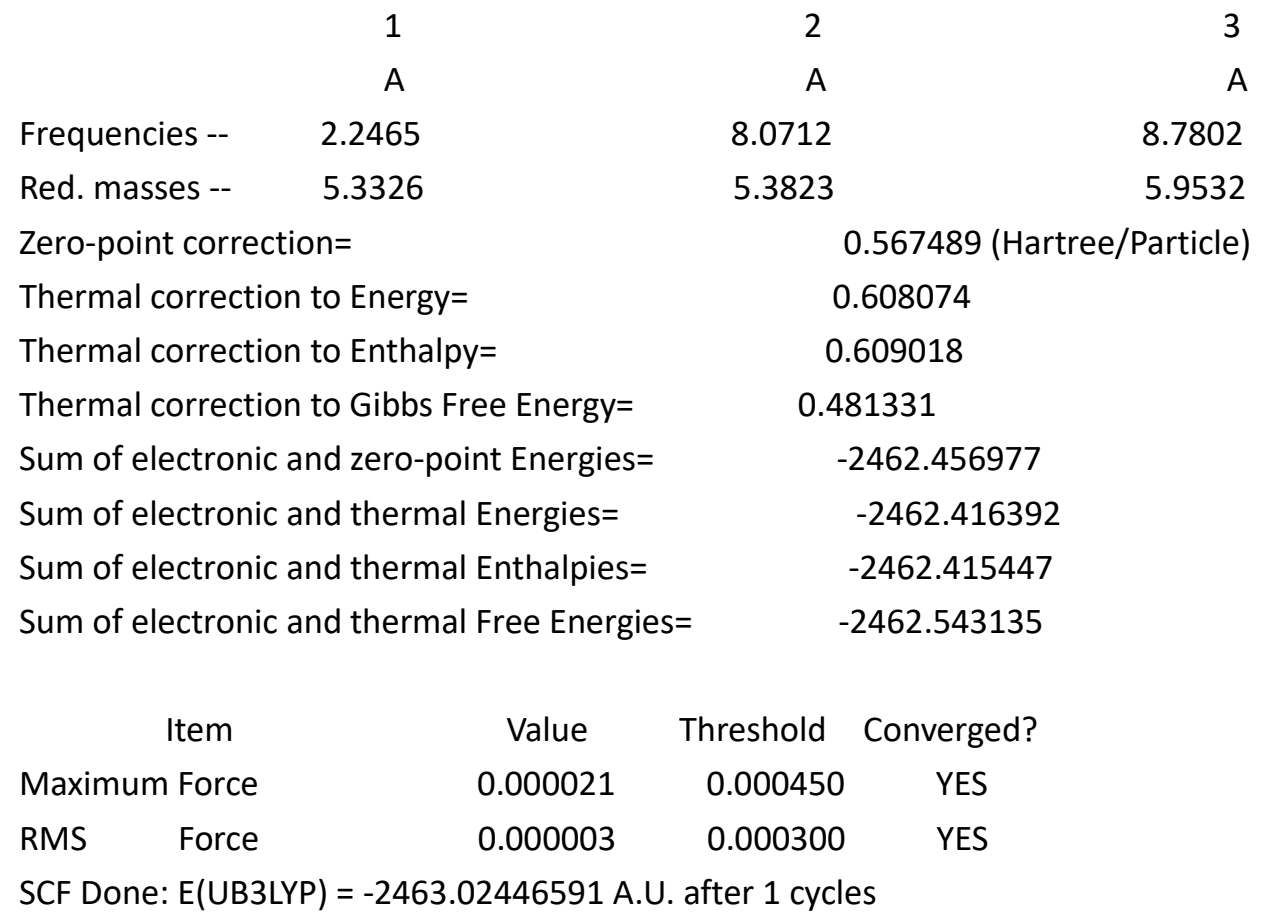

TS2

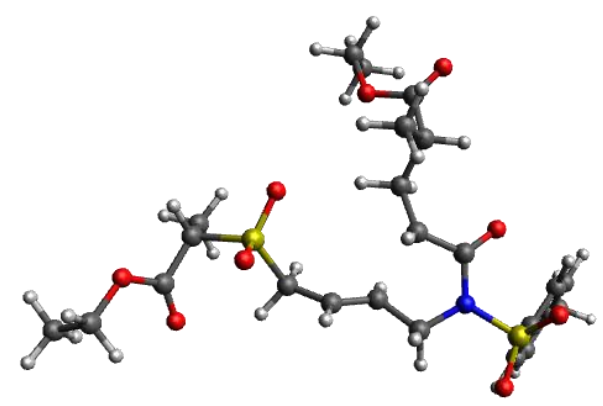


Cartesian coordinates (Angstroms):

70

$\begin{array}{llll}\text { C } & -3.948 & 1.453 & -2.918\end{array}$

$\begin{array}{llll}\text { C } & -2.963 & 1.654 & -1.804\end{array}$

$\begin{array}{llll}\text { C } & -2.731 & 0.535 & -0.861\end{array}$

$\begin{array}{llll}0 & -2.893 & -0.644 & -1.151\end{array}$

$\begin{array}{llll}\mathrm{N} & -2.361 & 0.970 & 0.414\end{array}$

$\begin{array}{llll}\mathrm{S} & -1.733 & -0.118 & 1.604\end{array}$

$\begin{array}{llll}0 & -0.691 & -0.919 & 0.974\end{array}$

$\begin{array}{llll}0 & -1.444 & 0.758 & 2.744\end{array}$

$\begin{array}{llll}\text { C } & -3.100 & -1.181 & 2.056\end{array}$

$\begin{array}{llll}\text { C } & -3.358 & -2.339 & 1.319\end{array}$

$\begin{array}{llll}\text { C } & -4.408 & -3.163 & 1.714\end{array}$

$\begin{array}{llll}\text { C } & -5.198 & -2.855 & 2.832\end{array}$

$\begin{array}{llll}\text { C } & -4.910 & -1.689 & 3.554\end{array}$

$\begin{array}{llll}\text { C } & -3.863 & -0.849 & 3.177\end{array}$

$\begin{array}{llll}\text { C } & -6.313 & -3.778 & 3.264\end{array}$

$\begin{array}{llll}\text { C } & -2.483 & 2.405 & 0.712\end{array}$

$\begin{array}{llll}\text { C } & -3.589 & 3.002 & -0.137\end{array}$

$\begin{array}{llll}\text { C } & -3.542 & 4.324 & -0.496\end{array}$

$\begin{array}{llll}C & -4.707 & 5.098 & -1.008\end{array}$

$\begin{array}{llll}\mathrm{S} & -4.330 & 5.793 & -2.681\end{array}$

$\begin{array}{llll}0 & -4.588 & 4.761 & -3.702\end{array}$

$\begin{array}{llll}0 & -3.018 & 6.458 & -2.606\end{array}$

$\begin{array}{llll}\text { C } & -5.590 & 7.124 & -2.968\end{array}$

$\begin{array}{llll}\text { C } & -5.330 & 8.279 & -2.013\end{array}$

$\begin{array}{llll}\text { C } & -7.021 & 6.589 & -2.872\end{array}$

$\begin{array}{llll}0 & -5.526 & 8.217 & -0.815\end{array}$

$\begin{array}{llll}0 & -4.875 & 9.354 & -2.665\end{array}$

$\begin{array}{llll}\text { C } & -4.550 & 10.523 & -1.861\end{array}$

$\begin{array}{llll}\text { C } & -5.779 & 11.385 & -1.621\end{array}$

$\begin{array}{llll}\text { H } & -4.789 & 0.855 & -2.548\end{array}$

$\begin{array}{llll}\mathrm{H} & -4.337 & 2.422 & -3.246\end{array}$

$\begin{array}{llll}H & -2.096 & 2.279 & -2.007\end{array}$

$\begin{array}{llll}H & -2.757 & -2.572 & 0.450\end{array}$

$\begin{array}{llll}\text { H } & -4.617 & -4.064 & 1.143\end{array}$

$\begin{array}{llll}\mathrm{H} & -5.507 & -1.437 & 4.427\end{array}$

$\begin{array}{llll}\text { H } & -3.627 & 0.040 & 3.751\end{array}$

$\begin{array}{llll}\text { H } & -6.827 & -4.215 & 2.401\end{array}$

$\begin{array}{llll}H & -7.055 & -3.253 & 3.874\end{array}$

$\begin{array}{llll}\text { H } & -5.923 & -4.610 & 3.864\end{array}$ 


$\begin{array}{rrrr}\text { H } & -1.536 & 2.928 & 0.525 \\ \text { H } & -2.704 & 2.514 & 1.777 \\ \text { H } & -4.562 & 2.518 & -0.052 \\ \text { H } & -2.598 & 4.863 & -0.441 \\ \text { H } & -4.925 & 5.981 & -0.394 \\ \text { H } & -5.610 & 4.491 & -1.112 \\ \text { H } & -5.349 & 7.429 & -3.991 \\ \text { H } & -7.131 & 5.692 & -3.486 \\ \text { H } & -7.720 & 7.347 & -3.241 \\ \text { H } & -7.288 & 6.362 & -1.836 \\ \text { H } & -3.797 & 11.046 & -2.454 \\ \text { H } & -4.106 & 10.185 & -0.923 \\ \text { H } & -6.243 & 11.677 & -2.569 \\ \text { H } & -5.490 & 12.297 & -1.086 \\ \text { H } & -6.516 & 10.852 & -1.014 \\ \text { C } & -3.329 & 0.728 & -4.151 \\ \text { C } & -2.274 & 1.591 & -4.871 \\ \text { C } & -4.408 & 0.319 & -5.145 \\ \text { O } & -4.501 & -0.779 & -5.650 \\ \text { O } & -5.240 & 1.350 & -5.431 \\ \text { C } & -6.278 & 1.095 & -6.406 \\ \text { C } & -7.507 & 0.474 & -5.759 \\ \text { H } & -2.875 & -0.208 & -3.818 \\ \text { H } & -2.699 & 2.553 & -5.176 \\ \text { H } & -1.895 & 1.077 & -5.761 \\ \text { H } & -1.418 & 1.785 & -4.216 \\ \text { H } & -5.876 & 0.448 & -7.189 \\ \text { H } & -6.501 & 2.079 & -6.825 \\ \text { H } & -7.271 & -0.517 & -5.360 \\ \text { H } & -8.305 & 0.364 & -6.502 \\ \text { H } & -7.879 & 1.105 & -4.945 \\ & & & \end{array}$

\section{1}

A

Frequencies -- -411.3205

Red. masses -- 9.5563

Zero-point correction=

Thermal correction to Energy=

Thermal correction to Enthalpy=

Thermal correction to Gibbs Free Energy=

Sum of electronic and zero-point Energies=

Sum of electronic and thermal Energies=

Sum of electronic and thermal Enthalpies=

Sum of electronic and thermal Free Energies=

$\begin{array}{rr}2 & 3 \\ \mathrm{~A} & \mathrm{~A} \\ 8.3579 & 9.6871 \\ 4.8886 & 4.2598 \\ 0.566629 & \text { (Hartree/Particle) } \\ 0.606373 & \\ 0.607317 & \\ 0.484810 & \\ -2462.446343 & \\ -2462.406599 & \\ -2462.405655 & \\ -2462.528162 & \end{array}$




$\begin{array}{lcccc} & \text { Item } & \text { Value } & \text { Threshold } & \text { Converged? } \\ \text { Maximum Force } & 0.000008 & 0.000450 & \text { YES } \\ \text { RMS } & \text { Force } & 0.000001 & 0.000300 & \text { YES }\end{array}$

SCF Done: $E(U B 3 L Y P)=-2463.01297233$ A.U. after 1 cycles

G3

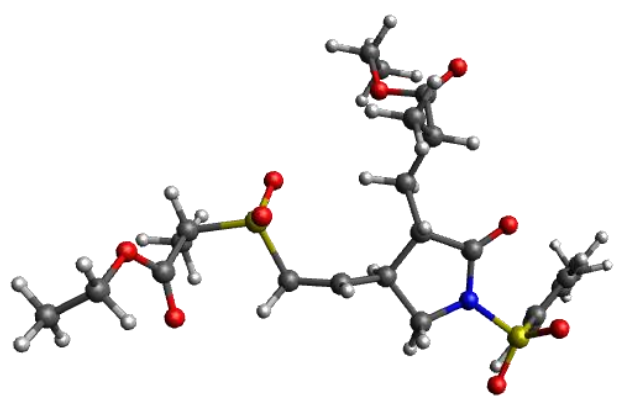

Cartesian coordinates (Angstroms):

70

$\begin{array}{lccc}\text { C } & -3.638 & 1.286 & -2.687 \\ \text { C } & -2.631 & 1.666 & -1.588 \\ \text { C } & -2.255 & 0.490 & -0.679 \\ \text { O } & -2.048 & -0.660 & -1.016 \\ \text { N } & -2.204 & 0.966 & 0.629 \\ \text { S } & -1.542 & 0.067 & 1.951 \\ \text { O } & -0.246 & -0.468 & 1.548 \\ \text { O } & -1.667 & 0.995 & 3.079 \\ \text { C } & -2.690 & -1.281 & 2.185 \\ \text { C } & -2.543 & -2.457 & 1.444 \\ \text { C } & -3.429 & -3.505 & 1.672 \\ \text { C } & -4.454 & -3.401 & 2.625 \\ \text { C } & -4.568 & -2.211 & 3.359\end{array}$




\begin{tabular}{|c|c|c|c|}
\hline C & -3.693 & -1.148 & 3.147 \\
\hline C & -5.420 & -4.541 & 2.841 \\
\hline & -2.408 & 2.417 & 0.732 \\
\hline$r$ & -3.139 & 2.761 & -0.597 \\
\hline C & -2.886 & 4.168 & -1.018 \\
\hline C & -3.933 & 5.178 & -1.263 \\
\hline$S$ & -4.085 & 5.529 & -3.098 \\
\hline 0 & -4.918 & 4.478 & -3.714 \\
\hline O & -2.735 & 5.810 & -3.614 \\
\hline C & -5.056 & 7.106 & -3.244 \\
\hline C & -4.222 & 8.259 & -2.705 \\
\hline C & -6.423 & 7.001 & -2.566 \\
\hline 0 & -3.965 & 8.407 & -1.526 \\
\hline 0 & -3.828 & 9.075 & -3.688 \\
\hline C & -2.992 & 10.205 & -3.313 \\
\hline C & -3.836 & 11.397 & -2.894 \\
\hline $\mathrm{H}$ & -4.448 & 0.708 & -2.223 \\
\hline $\mathrm{H}$ & -4.094 & 2.198 & -3.086 \\
\hline $\mathrm{H}$ & -1.691 & 2.014 & -2.041 \\
\hline $\mathrm{H}$ & -1.758 & -2.536 & 0.702 \\
\hline $\mathrm{H}$ & -3.321 & -4.424 & 1.101 \\
\hline $\mathrm{H}$ & -5.347 & -2.119 & 4.111 \\
\hline $\mathrm{H}$ & -3.768 & -0.236 & 3.729 \\
\hline $\mathrm{H}$ & -6.175 & -4.572 & 2.044 \\
\hline $\mathrm{H}$ & -5.950 & -4.444 & 3.794 \\
\hline $\mathrm{H}$ & -4.905 & -5.508 & 2.834 \\
\hline $\mathrm{H}$ & -1.447 & 2.940 & 0.806 \\
\hline $\mathrm{H}$ & -2.999 & 2.664 & 1.615 \\
\hline $\mathrm{H}$ & -4.214 & 2.601 & -0.446 \\
\hline $\mathrm{H}$ & -1.857 & 4.465 & -1.208 \\
\hline $\mathrm{H}$ & -3.695 & 6.160 & -0.838 \\
\hline $\mathrm{H}$ & -4.927 & 4.860 & -0.939 \\
\hline $\mathrm{H}$ & -5.155 & 7.197 & -4.329 \\
\hline $\mathrm{H}$ & -6.942 & 6.098 & -2.900 \\
\hline $\mathrm{H}$ & -7.034 & 7.868 & -2.838 \\
\hline $\mathrm{H}$ & -6.325 & 6.987 & -1.478 \\
\hline $\mathrm{H}$ & -2.414 & 10.413 & -4.215 \\
\hline $\mathrm{H}$ & -2.319 & 9.886 & -2.514 \\
\hline $\mathrm{H}$ & -4.540 & 11.675 & -3.685 \\
\hline $\mathrm{H}$ & -3.186 & 12.257 & -2.696 \\
\hline $\mathrm{H}$ & -4.396 & 11.176 & -1.981 \\
\hline C & -3.027 & 0.474 & -3.852 \\
\hline C & -2.131 & 1.340 & -4.763 \\
\hline C & -4.105 & -0.178 & -4.708 \\
\hline
\end{tabular}




$\begin{array}{cccc}\mathrm{O} & -4.069 & -1.319 & -5.116 \\ \mathrm{O} & -5.103 & 0.692 & -5.000 \\ \mathrm{C} & -6.166 & 0.204 & -5.849 \\ \mathrm{C} & -7.233 & -0.520 & -5.040 \\ \mathrm{H} & -2.442 & -0.355 & -3.447 \\ \mathrm{H} & -2.697 & 2.179 & -5.181 \\ \mathrm{H} & -1.726 & 0.744 & -5.587 \\ \mathrm{H} & -1.280 & 1.747 & -4.205 \\ \mathrm{H} & -5.737 & -0.452 & -6.610 \\ \mathrm{H} & -6.566 & 1.102 & -6.325 \\ \mathrm{H} & -6.822 & -1.426 & -4.586 \\ \mathrm{H} & -8.065 & -0.810 & -5.693 \\ \mathrm{H} & -7.627 & 0.127 & -4.250\end{array}$

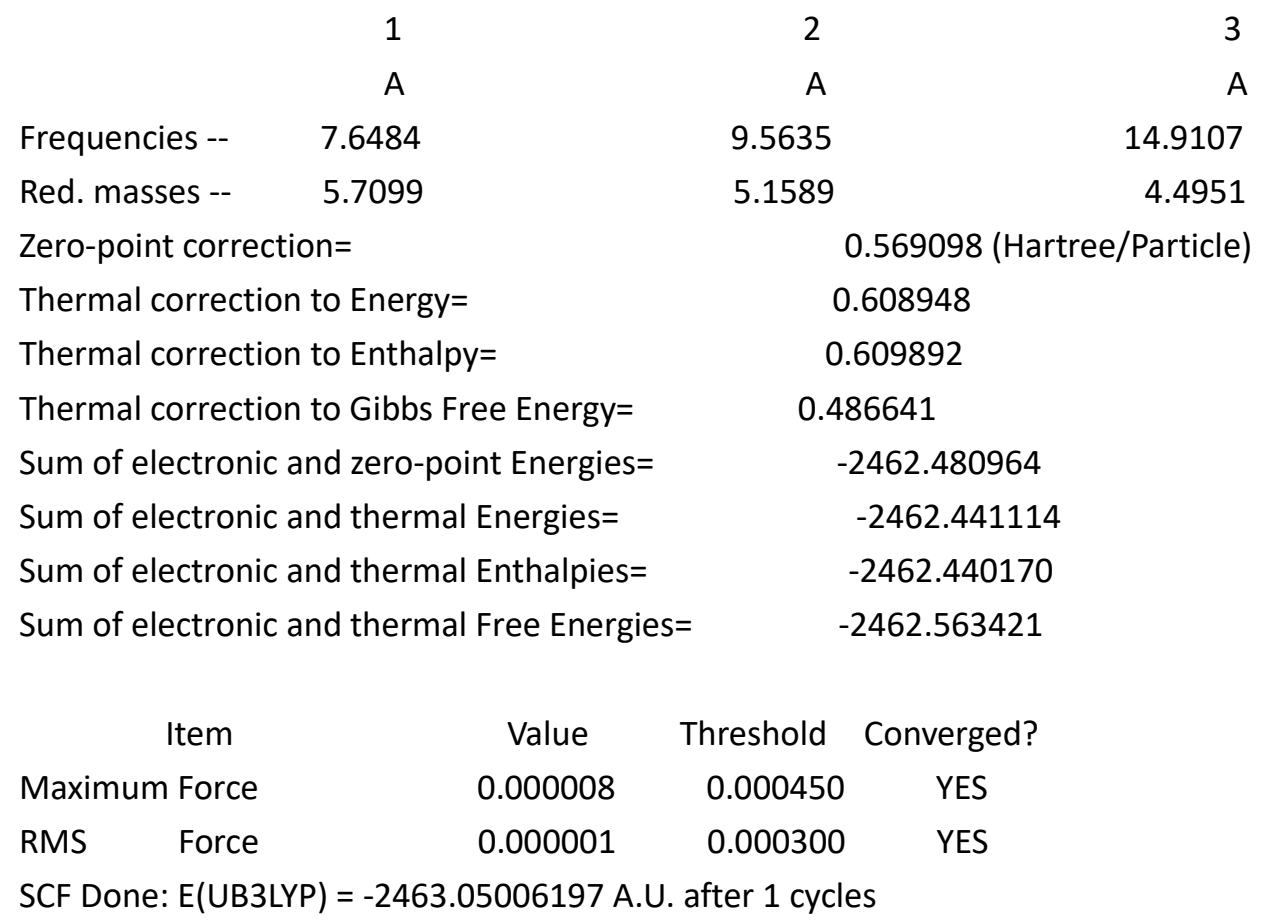

TS3 


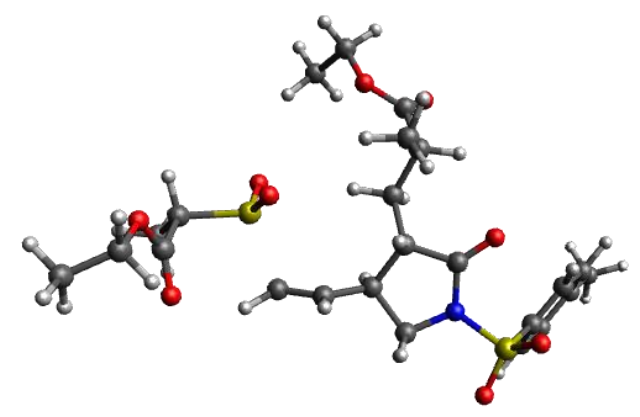

Cartesian coordinates (Angstroms):

70

$\begin{array}{llll}\mathrm{S} & -4.964 & 5.112 & -3.143\end{array}$

$\begin{array}{llll}\text { C } & -5.522 & 6.853 & -3.602\end{array}$

$\begin{array}{llll}\text { C } & -6.838 & 7.200 & -2.910\end{array}$

$\begin{array}{llll}\text { H } & -6.698 & 7.318 & -1.832\end{array}$

$\begin{array}{llll}H & -7.225 & 8.145 & -3.306\end{array}$

$\begin{array}{llll}H & -7.579 & 6.419 & -3.097\end{array}$

$\begin{array}{llll}\text { C } & -4.398 & 7.811 & -3.259\end{array}$

$\begin{array}{llll}0 & -4.060 & 8.066 & -2.117\end{array}$

$\begin{array}{llll}0 & -3.840 & 8.327 & -4.359\end{array}$

$\begin{array}{llll}\text { C } & -2.724 & 9.239 & -4.166\end{array}$

$\begin{array}{llll}H & -2.124 & 8.880 & -3.327\end{array}$

$\begin{array}{llll}\text { C } & -3.209 & 10.662 & -3.939\end{array}$

$\begin{array}{llll}H & -3.772 & 10.736 & -3.004\end{array}$

$\begin{array}{llll}H & -2.349 & 11.338 & -3.875\end{array}$

$\begin{array}{llll}H & -3.845 & 10.994 & -4.766\end{array}$

$\begin{array}{llll}H & -2.150 & 9.149 & -5.090\end{array}$

$\begin{array}{llll}H & -5.637 & 6.775 & -4.687\end{array}$

$\begin{array}{llll}O & -3.655 & 4.916 & -3.803\end{array}$

$\begin{array}{llll}0 & -6.108 & 4.229 & -3.481\end{array}$

$\begin{array}{llll}\text { C } & -3.875 & 1.356 & -2.453\end{array}$

$\begin{array}{llll}\text { C } & -2.905 & 1.845 & -1.365\end{array}$ 


\begin{tabular}{|c|c|c|c|}
\hline c & -2.311 & 0.710 & -0.523 \\
\hline O & -1.893 & -0.358 & -0.926 \\
\hline $\mathrm{N}$ & -2.339 & 1.112 & 0.811 \\
\hline & -1.535 & 0.262 & 2.087 \\
\hline O & -0.175 & -0.043 & 1.655 \\
\hline 0 & -1.793 & 1.102 & 3.260 \\
\hline C & -2.461 & -1.256 & 2.249 \\
\hline C & -2.161 & -2.346 & 1.428 \\
\hline C & -2.881 & -3.526 & 1.598 \\
\hline C & -3.885 & -3.636 & 2.571 \\
\hline C & -4.151 & -2.527 & 3.387 \\
\hline C & -3.447 & -1.335 & 3.234 \\
\hline C & -4.671 & -4.916 & 2.722 \\
\hline C & -2.799 & 2.494 & 1.000 \\
\hline C & -3.570 & 2.790 & -0.316 \\
\hline C & -3.525 & 4.244 & -0.655 \\
\hline C & -4.631 & 5.056 & -0.907 \\
\hline $\mathrm{H}$ & -4.636 & 0.719 & -1.985 \\
\hline $\mathrm{H}$ & -4.399 & 2.226 & -2.864 \\
\hline $\mathrm{H}$ & -2.056 & 2.366 & -1.828 \\
\hline $\mathrm{H}$ & -1.393 & -2.260 & 0.670 \\
\hline $\mathrm{H}$ & -2.655 & -4.379 & 0.963 \\
\hline $\mathrm{H}$ & -4.915 & -2.599 & 4.157 \\
\hline $\mathrm{H}$ & -3.640 & -0.484 & 3.878 \\
\hline $\mathrm{H}$ & -5.451 & -4.989 & 1.952 \\
\hline $\mathrm{H}$ & -5.165 & -4.973 & 3.697 \\
\hline $\mathrm{H}$ & -4.027 & -5.795 & 2.613 \\
\hline $\mathrm{H}$ & -1.945 & 3.171 & 1.128 \\
\hline $\mathrm{H}$ & -3.431 & 2.575 & 1.885 \\
\hline $\mathrm{H}$ & -4.612 & 2.470 & -0.185 \\
\hline $\mathrm{H}$ & -2.534 & 4.683 & -0.766 \\
\hline $\mathrm{H}$ & -4.498 & 6.134 & -0.836 \\
\hline $\mathrm{H}$ & -5.623 & 4.685 & -0.652 \\
\hline C & -3.234 & 0.572 & -3.630 \\
\hline C & -2.153 & 1.373 & -4.370 \\
\hline C & -4.389 & 0.136 & -4.524 \\
\hline O & -5.049 & -0.867 & -4.343 \\
\hline 0 & -4.633 & 1.030 & -5.507 \\
\hline C & -5.792 & 0.791 & -6.339 \\
\hline C & -7.056 & 1.328 & -5.684 \\
\hline $\mathrm{H}$ & -2.806 & -0.350 & -3.228 \\
\hline $\mathrm{H}$ & -2.513 & 2.367 & -4.652 \\
\hline $\mathrm{H}$ & -1.840 & 0.854 & -5.282 \\
\hline $\mathrm{H}$ & -1.264 & 1.487 & -3.740 \\
\hline
\end{tabular}




$\begin{array}{cccc}\mathrm{H} & -5.868 & -0.281 & -6.539 \\ \mathrm{H} & -5.567 & 1.319 & -7.270 \\ \mathrm{H} & -7.303 & 0.744 & -4.793 \\ \mathrm{H} & -7.897 & 1.259 & -6.384 \\ \mathrm{H} & -6.924 & 2.374 & -5.391\end{array}$

\section{1}

A

Frequencies -- -289.2915

Red. masses -- $\quad 9.6170$

Zero-point correction=

Thermal correction to Energy=

Thermal correction to Enthalpy=

Thermal correction to Gibbs Free Energy=

Sum of electronic and zero-point Energies=

Sum of electronic and thermal Energies=

Sum of electronic and thermal Enthalpies=

Sum of electronic and thermal Free Energies=
2

A

9.7432

5.2135

14.6506

5.0736

0.567963 (Hartree/Particle)

0.607551

0.608495

0.487533

$-2462.477572$

$-2462.437984$

$-2462.437040$

$-2462.558002$

\begin{tabular}{|c|c|c|c|}
\hline Item & Value & Threshold & Converged? \\
\hline Maximum Force & 0.000011 & 0.000450 & YES \\
\hline Force & 0.000001 & 0.000300 & YES \\
\hline
\end{tabular}

SCF Done: $E(U B 3 L Y P)=-2463.04553428$ A.U. after 1 cycles

G4sm

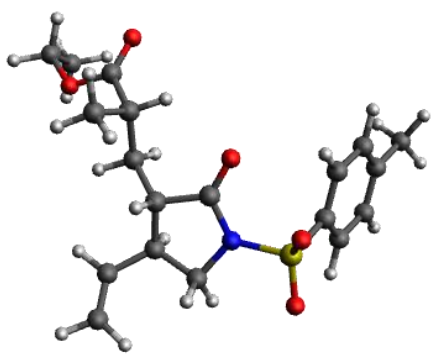


Cartesian coordinates (Angstroms):

51

$\begin{array}{llll}\text { C } & -5.566 & 0.919 & -2.859\end{array}$

$\begin{array}{llll}\text { C } & -4.982 & -0.272 & -2.084\end{array}$

$\begin{array}{llll}\text { C } & -5.883 & -1.512 & -2.054\end{array}$

$\begin{array}{llll}O & -6.583 & -1.940 & -2.952\end{array}$

$\begin{array}{llll}\text { N } & -5.761 & -2.078 & -0.787\end{array}$

$\begin{array}{llll}\mathrm{S} & -6.351 & -3.651 & -0.378\end{array}$

$\begin{array}{llll}0 & -5.936 & -4.586 & -1.418\end{array}$

$\begin{array}{llll}0 & -5.927 & -3.817 & 1.014\end{array}$

$\begin{array}{llll}\text { C } & -8.129 & -3.473 & -0.422\end{array}$

$\begin{array}{llll}\text { C } & -8.814 & -3.634 & -1.628\end{array}$

$\begin{array}{llll}\text { C } & -10.202 & -3.520 & -1.627\end{array}$

$\begin{array}{llll}\text { C } & -10.912 & -3.253 & -0.447\end{array}$

$\begin{array}{llll}\text { C } & -10.194 & -3.110 & 0.749\end{array}$

$\begin{array}{llll}\text { C } & -8.806 & -3.218 & 0.772\end{array}$

$\begin{array}{llll}\text { C } & -12.414 & -3.104 & -0.470\end{array}$

$\begin{array}{llll}\text { C } & -4.784 & -1.385 & 0.071\end{array}$

$\begin{array}{llll}\text { C } & -4.713 & 0.010 & -0.579\end{array}$

$\begin{array}{llll}\text { C } & -3.463 & 0.802 & -0.307\end{array}$

$\begin{array}{llll}\text { C } & -2.464 & 0.468 & 0.510\end{array}$

$\begin{array}{llll}\mathrm{H} & -6.547 & 1.162 & -2.430\end{array}$

$\begin{array}{llll}\mathrm{H} & -4.925 & 1.792 & -2.688\end{array}$

$\begin{array}{llll}H & -4.037 & -0.594 & -2.546\end{array}$

$\begin{array}{llll}H & -8.267 & -3.832 & -2.541\end{array}$

$\begin{array}{llll}H & -10.744 & -3.644 & -2.561\end{array}$

$\begin{array}{llll}H & -10.729 & -2.920 & 1.676\end{array}$

$\begin{array}{llll}H & -8.252 & -3.127 & 1.701\end{array}$

$\begin{array}{llll}H & -12.701 & -2.069 & -0.698\end{array}$

$\begin{array}{llll}H & -12.858 & -3.360 & 0.498\end{array}$

$\begin{array}{llll}H & -12.869 & -3.742 & -1.234\end{array}$

$\begin{array}{llll}\mathrm{H} & -3.817 & -1.899 & 0.036\end{array}$

$\begin{array}{llll}H & -5.128 & -1.365 & 1.106\end{array}$

$\begin{array}{llll}H & -5.574 & 0.590 & -0.210\end{array}$

$\begin{array}{llll}\text { C } & -5.723 & 0.716 & -4.385\end{array}$

$\begin{array}{llll}\text { C } & -4.385 & 0.460 & -5.105\end{array}$

$\begin{array}{llll}\text { C } & -6.418 & 1.925 & -4.997\end{array}$

$\begin{array}{llll}0 & -7.454 & 1.890 & -5.626\end{array}$

$\begin{array}{llll}0 & -5.720 & 3.067 & -4.768\end{array}$

$\begin{array}{llll}\text { C } & -6.267 & 4.287 & -5.321\end{array}$

$\begin{array}{llll}\text { C } & -7.307 & 4.900 & -4.395\end{array}$ 


$\begin{array}{cccc}\mathrm{H} & -6.392 & -0.128 & -4.561 \\ \mathrm{H} & -3.664 & 1.260 & -4.905 \\ \mathrm{H} & -4.535 & 0.399 & -6.188 \\ \mathrm{H} & -3.948 & -0.492 & -4.785 \\ \mathrm{H} & -6.694 & 4.067 & -6.303 \\ \mathrm{H} & -5.401 & 4.943 & -5.441 \\ \mathrm{H} & -8.174 & 4.240 & -4.301 \\ \mathrm{H} & -7.648 & 5.860 & -4.801 \\ \mathrm{H} & -6.886 & 5.079 & -3.400 \\ \mathrm{H} & -3.406 & 1.752 & -0.838 \\ \mathrm{H} & -2.454 & -0.454 & 1.086 \\ \mathrm{H} & -1.605 & 1.120 & 0.640\end{array}$

\begin{tabular}{|c|c|c|c|c|}
\hline \multicolumn{5}{|c|}{1} \\
\hline \multicolumn{2}{|r|}{ A } & \multicolumn{2}{|l|}{ A } & A \\
\hline Frequencies -- & 10.1439 & \multicolumn{2}{|l|}{11.9956} & 22.2679 \\
\hline Red. masses -- & 4.3944 & \multicolumn{2}{|l|}{4.9653} & 1.0118 \\
\hline \multicolumn{3}{|c|}{ Zero-point correction= } & \multicolumn{2}{|c|}{0.420240 (Hartree/Particle) } \\
\hline \multicolumn{2}{|c|}{ Thermal correction to Energy= } & \multicolumn{3}{|c|}{0.447671} \\
\hline \multicolumn{2}{|c|}{ Thermal correction to Enthalpy= } & \multicolumn{3}{|c|}{0.448615} \\
\hline \multicolumn{2}{|c|}{ Thermal correction to Gibbs Free Energy= } & \multicolumn{3}{|c|}{0.356812} \\
\hline \multicolumn{2}{|c|}{ Sum of electronic and zero-point Energies: } & \multicolumn{3}{|c|}{-1567.664814} \\
\hline \multicolumn{2}{|c|}{ Sum of electronic and thermal Energies= } & \multicolumn{3}{|c|}{-1567.637384} \\
\hline \multicolumn{2}{|c|}{ Sum of electronic and thermal Enthalpies } & \multicolumn{3}{|c|}{-1567.636439} \\
\hline \multicolumn{3}{|c|}{ Sum of electronic and thermal Free Energies= } & \multicolumn{2}{|l|}{1567.728242} \\
\hline Item & Value & Threshold & Converged? & \\
\hline Maximum Force & 0.000046 & 0.000450 & YES & \\
\hline RMS & 0.000006 & 0.000300 & YES & \\
\hline
\end{tabular}

G4so 


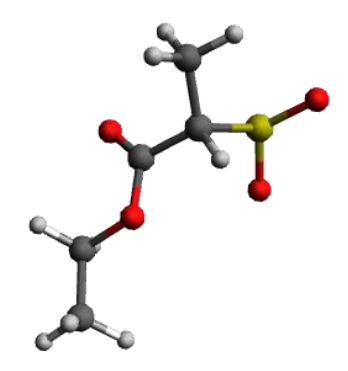

Cartesian coordinates (Angstroms):

19

$\begin{array}{llll}\mathrm{S} & 8.165 & -7.362 & 6.948\end{array}$

$\begin{array}{llll}0 & 8.748 & -7.388 & 8.317\end{array}$

$\begin{array}{llll}0 & 7.822 & -8.621 & 6.234\end{array}$

$\begin{array}{llll}\text { C } & 6.524 & -6.405 & 7.124\end{array}$

$\begin{array}{llll}\text { C } & 5.898 & -6.389 & 5.740\end{array}$

$\begin{array}{llll}\text { C } & 6.806 & -5.019 & 7.682\end{array}$

$\begin{array}{llll}\text { O } & 6.290 & -5.679 & 4.838\end{array}$

$\begin{array}{llll}0 & 4.883 & -7.257 & 5.658\end{array}$

$\begin{array}{llll}\text { C } & 4.250 & -7.375 & 4.356\end{array}$

$\begin{array}{llll}\text { C } & 3.161 & -8.423 & 4.474\end{array}$

$\begin{array}{llll}\mathrm{H} & 5.954 & -7.037 & 7.809\end{array}$

$\begin{array}{llll}H & 7.384 & -5.086 & 8.607\end{array}$

$\begin{array}{llll}\mathrm{H} & 5.857 & -4.518 & 7.902\end{array}$

$\begin{array}{llll}\mathrm{H} & 7.350 & -4.413 & 6.952\end{array}$

$\begin{array}{llll}\mathrm{H} & 5.017 & -7.652 & 3.627\end{array}$

$\begin{array}{llll}H & 3.855 & -6.394 & 4.072\end{array}$

$\begin{array}{llll}\text { H } & 3.582 & -9.390 & 4.769\end{array}$

$\begin{array}{llll}H & 2.661 & -8.545 & 3.508\end{array}$

$\begin{array}{llll}H & 2.412 & -8.129 & 5.216\end{array}$ 
A

Frequencies -- 27.7464

Red. masses -- 4.2890

Zero-point correction=

Thermal correction to Energy=

Thermal correction to Enthalpy=

Thermal correction to Gibbs Free Energy=

Sum of electronic and zero-point Energies=

Sum of electronic and thermal Energies=

Sum of electronic and thermal Enthalpies=

Sum of electronic and thermal Free Energies=
A

A

51.4832

71.6127

6.8063

3.4290

0.145583 (Hartree/Particle)

0.157385

0.158329

0.105571

$-894.819905$

$-894.808103$

$-894.807159$

$-894.859917$

\begin{tabular}{|c|c|c|c|}
\hline Item & Value & Threshold & Converged? \\
\hline Maximum Force & 0.000019 & 0.000450 & YES \\
\hline Force & 0.000003 & 0.000300 & YES \\
\hline
\end{tabular}

SCF Done: $E(U B 3 L Y P)=-894.965488099$ A.U. after 1 cycles

TS4

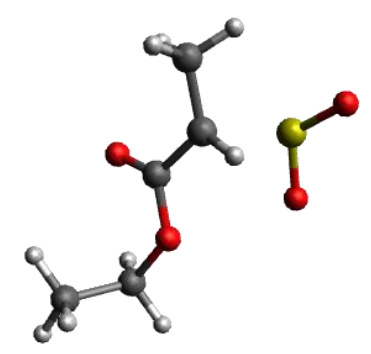

Cartesian coordinates (Angstroms):

19

$\begin{array}{llll}\text { S } & -4.750 & 5.206 & -3.381 \\ \text { C } & -5.904 & 7.393 & -3.732\end{array}$




$\begin{array}{lrrr}\mathrm{C} & -7.083 & 7.260 & -2.834 \\ \mathrm{H} & -6.795 & 7.391 & -1.788 \\ \mathrm{H} & -7.818 & 8.044 & -3.078 \\ \mathrm{H} & -7.583 & 6.297 & -2.975 \\ \mathrm{C} & -4.791 & 8.289 & -3.360 \\ \mathrm{O} & -4.618 & 8.727 & -2.235 \\ \mathrm{O} & -3.988 & 8.524 & -4.416 \\ \mathrm{C} & -2.797 & 9.313 & -4.167 \\ \mathrm{H} & -2.403 & 9.046 & -3.183 \\ \mathrm{C} & -3.089 & 10.803 & -4.263 \\ \mathrm{H} & -3.778 & 11.115 & -3.473 \\ \mathrm{H} & -2.157 & 11.369 & -4.149 \\ \mathrm{H} & -3.525 & 11.053 & -5.236 \\ \mathrm{H} & -2.098 & 8.987 & -4.940 \\ \mathrm{H} & -6.018 & 7.177 & -4.792 \\ \mathrm{O} & -3.419 & 5.387 & -3.985 \\ \mathrm{O} & -5.724 & 4.331 & -4.060\end{array}$

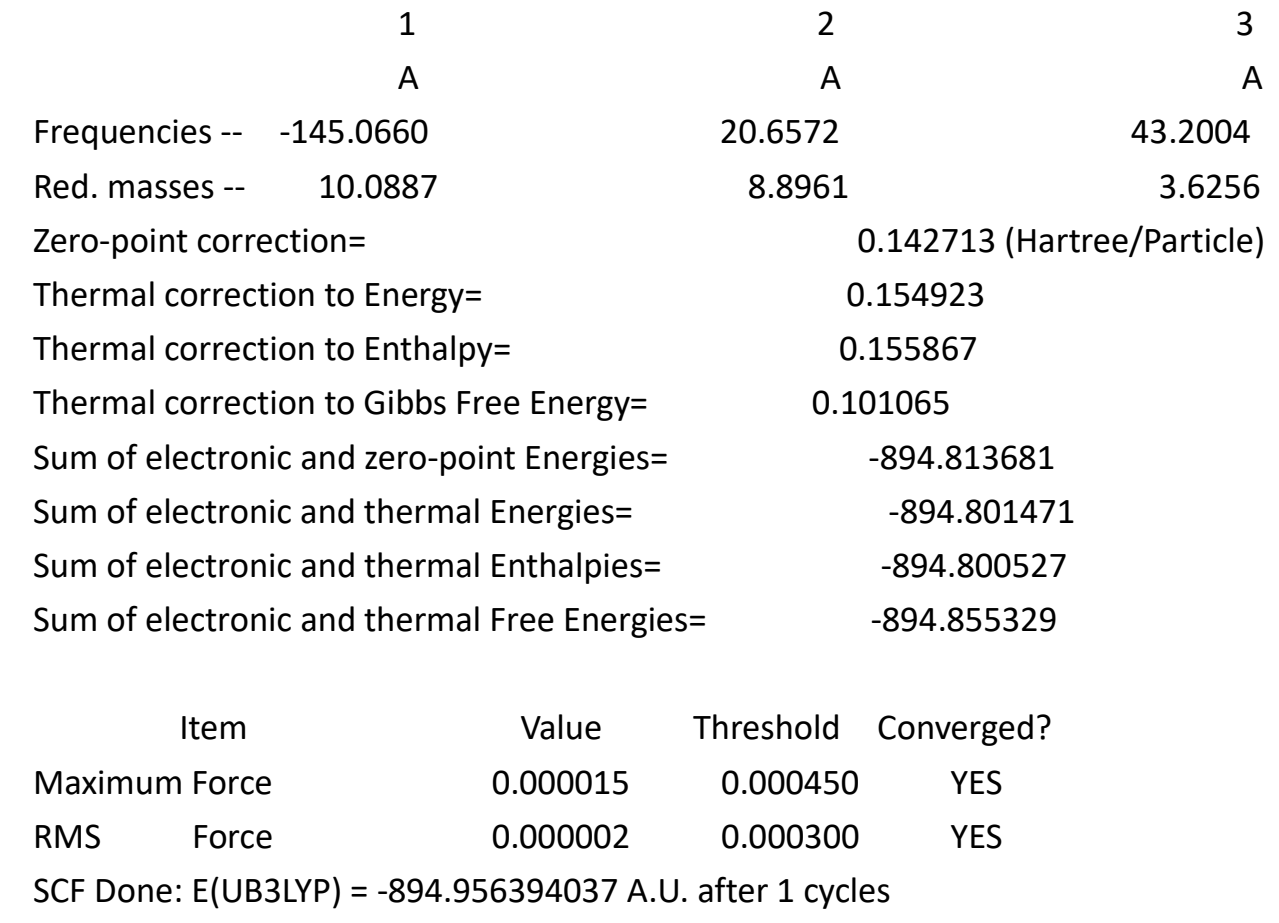

G5sm 


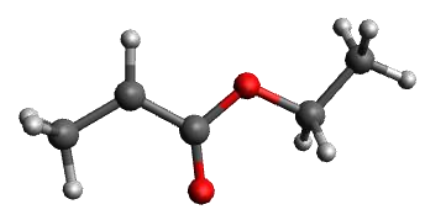

Cartesian coordinates (Angstroms):

16

$\begin{array}{llll}C & 5.316 & -5.765 & 7.357\end{array}$

$\begin{array}{llll}\text { C } & 5.421 & -6.535 & 6.132\end{array}$

$\begin{array}{llll}0 & 6.465 & -6.766 & 5.533\end{array}$

$\begin{array}{llll}0 & 4.205 & -6.981 & 5.712\end{array}$

$\begin{array}{llll}\text { C } & 4.213 & -7.759 & 4.499\end{array}$

$\begin{array}{llll}\text { C } & 2.778 & -8.149 & 4.197\end{array}$

$\begin{array}{llll}\mathrm{H} & 4.855 & -8.635 & 4.641\end{array}$

$\begin{array}{llll}\mathrm{H} & 4.654 & -7.160 & 3.694\end{array}$

$\begin{array}{llll}H & 2.355 & -8.745 & 5.012\end{array}$

$\begin{array}{llll}H & 2.739 & -8.745 & 3.278\end{array}$

$\begin{array}{llll}H & 2.153 & -7.262 & 4.058\end{array}$

$\begin{array}{llll}\text { C } & 6.513 & -5.174 & 8.005\end{array}$

$\begin{array}{llll}\text { H } & 4.329 & -5.632 & 7.790\end{array}$

$\begin{array}{llll}\text { H } & 7.413 & -5.403 & 7.431\end{array}$

$\begin{array}{llll}\mathrm{H} & 6.638 & -5.554 & 9.030\end{array}$

$\begin{array}{llll}H & 6.417 & -4.081 & 8.095\end{array}$

A

A

A

Frequencies -- $\quad 57.6382$

96.6910

112.5151

Red. masses -- $\quad 2.7414$

1.2633

1.7396 
Zero-point correction=

Thermal correction to Energy=

Thermal correction to Enthalpy=

Thermal correction to Gibbs Free Energy=

Sum of electronic and zero-point Energies=

Sum of electronic and thermal Energies=

Sum of electronic and thermal Enthalpies=

Sum of electronic and thermal Free Energies=
0.133822 (Hartree/Particle)

0.142449

0.143393

0.099614

$-346.233563$

$-346.224936$

$-346.223992$

$-346.267771$

\begin{tabular}{|c|c|c|c|}
\hline Item & Value & Threshold & Converged? \\
\hline Maximum Force & 0.000047 & 0.000450 & YES \\
\hline Force & 0.000008 & 0.000300 & YES \\
\hline
\end{tabular}

SCF Done: $E(U B 3 L Y P)=-346.367384892$ A.U. after 1 cycles

$\mathrm{SO} 2$

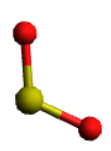

Cartesian coordinates (Angstroms):

3

$\begin{array}{lrrr}S & 9.637 & -7.552 & 6.179 \\ O & 9.780 & -6.966 & 7.512 \\ O & 10.754 & -8.308 & 5.610\end{array}$


A

Frequencies -- $\quad 502.6740$

Red. masses -- 18.5532

Zero-point correction=

Thermal correction to Energy=

Thermal correction to Enthalpy=

Thermal correction to Gibbs Free Energy=

Sum of electronic and zero-point Energies=

Sum of electronic and thermal Energies=

Sum of electronic and thermal Enthalpies=

Sum of electronic and thermal Free Energies=
A

A

1139.6639

1336.5782

18.0132

20.3264

0.006786 (Hartree/Particle)

0.009872

0.010816

$-0.018091$

$-548.580697$

$-548.577611$

$-548.576667$

$-548.605575$

\begin{tabular}{|c|c|c|c|}
\hline Item & Value & Threshold & Converged? \\
\hline Maximum Force & 0.000189 & 0.000450 & YES \\
\hline Force & 0.000160 & 0.000300 & YES \\
\hline
\end{tabular}

SCF Done: $E(R B 3 L Y P)=-548.587483253$ A.U. after 1 cycles

TS1C

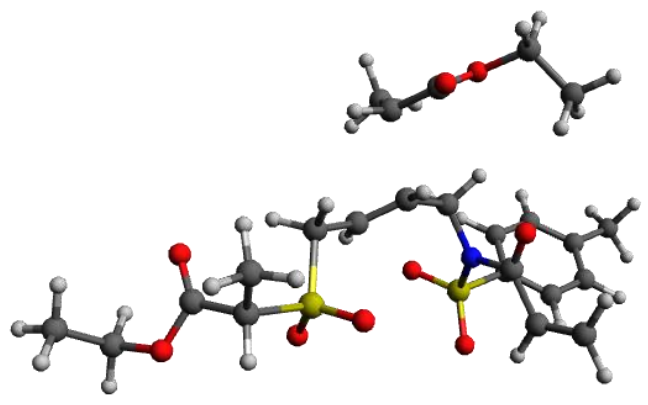

Cartesian coordinates (Angstroms):

70

$\begin{array}{llll}C & -5.141 & 4.977 & 2.369\end{array}$

$\begin{array}{llll}\text { C } & -4.907 & 4.169 & 3.612\end{array}$ 


\begin{tabular}{|c|c|c|c|}
\hline $\mathrm{H}$ & -5.399 & 4.642 & 4.476 \\
\hline $\mathrm{H}$ & -3.838 & 4.107 & 3.842 \\
\hline $\mathrm{H}$ & -5.314 & 3.159 & 3.527 \\
\hline $\mathrm{H}$ & -4.671 & 5.955 & 2.330 \\
\hline C & -6.429 & 4.975 & 1.662 \\
\hline O & -7.210 & 3.909 & 1.999 \\
\hline C & -8.485 & 3.802 & 1.323 \\
\hline $\mathrm{H}$ & -9.165 & 3.390 & 2.075 \\
\hline $\mathrm{H}$ & -8.817 & 4.804 & 1.043 \\
\hline C & -8.384 & 2.896 & 0.105 \\
\hline $\mathrm{H}$ & -8.074 & 1.885 & 0.394 \\
\hline $\mathrm{H}$ & -9.362 & 2.825 & -0.386 \\
\hline $\mathrm{H}$ & -7.659 & 3.285 & -0.614 \\
\hline O & -6.752 & 5.818 & 0.840 \\
\hline C & -4.415 & 1.363 & -3.850 \\
\hline C & -3.667 & 1.406 & -2.743 \\
\hline C & -4.218 & 2.055 & -1.522 \\
\hline 0 & -5.224 & 2.751 & -1.558 \\
\hline $\mathrm{N}$ & -3.558 & 1.910 & -0.277 \\
\hline$S$ & -2.381 & 0.710 & 0.145 \\
\hline O & -1.526 & 0.467 & -1.013 \\
\hline 0 & -1.818 & 1.154 & 1.421 \\
\hline C & -3.343 & -0.772 & 0.458 \\
\hline C & -3.707 & -1.601 & -0.606 \\
\hline C & -4.463 & -2.740 & -0.347 \\
\hline C & -4.859 & -3.070 & 0.958 \\
\hline C & -4.466 & -2.228 & 2.007 \\
\hline C & -3.711 & -1.081 & 1.768 \\
\hline C & -5.701 & -4.296 & 1.220 \\
\hline C & -4.154 & 2.683 & 0.850 \\
\hline C & -3.815 & 4.158 & 0.748 \\
\hline C & -2.553 & 4.605 & 1.069 \\
\hline C & -2.088 & 5.980 & 0.739 \\
\hline$S$ & -0.896 & 5.909 & -0.677 \\
\hline 0 & -1.652 & 5.635 & -1.910 \\
\hline 0 & 0.237 & 5.059 & -0.280 \\
\hline C & -0.229 & 7.635 & -0.853 \\
\hline C & 0.638 & 7.960 & 0.352 \\
\hline C & -1.337 & 8.665 & -1.078 \\
\hline $\mathrm{O}$ & 0.196 & 8.153 & 1.469 \\
\hline O & 1.934 & 8.012 & 0.020 \\
\hline C & 2.877 & 8.274 & 1.095 \\
\hline C & 3.047 & 9.767 & 1.325 \\
\hline $\mathrm{H}$ & -5.417 & 1.780 & -3.864 \\
\hline
\end{tabular}




$\begin{array}{rrrr}\mathrm{H} & -4.037 & 0.920 & -4.767 \\ \mathrm{H} & -2.661 & 1.011 & -2.718 \\ \mathrm{H} & -3.392 & -1.365 & -1.617 \\ \mathrm{H} & -4.743 & -3.391 & -1.172 \\ \mathrm{H} & -4.747 & -2.476 & 3.027 \\ \mathrm{H} & -3.390 & -0.445 & 2.586 \\ \mathrm{H} & -5.621 & -4.622 & 2.261 \\ \mathrm{H} & -5.402 & -5.131 & 0.577 \\ \mathrm{H} & -6.761 & -4.094 & 1.018 \\ \mathrm{H} & -3.750 & 2.273 & 1.774 \\ \mathrm{H} & -5.232 & 2.529 & 0.831 \\ \mathrm{H} & -4.401 & 4.730 & 0.034 \\ \mathrm{H} & -1.856 & 3.953 & 1.589 \\ \mathrm{H} & -1.532 & 6.466 & 1.547 \\ \mathrm{H} & -2.906 & 6.626 & 0.408 \\ \mathrm{H} & 0.400 & 7.528 & -1.741 \\ \mathrm{H} & -2.011 & 8.327 & -1.870 \\ \mathrm{H} & -0.895 & 9.618 & -1.387 \\ \mathrm{H} & -1.906 & 8.840 & -0.162 \\ \mathrm{H} & 3.803 & 7.809 & 0.751 \\ \mathrm{H} & 2.526 & 7.766 & 1.995 \\ \mathrm{H} & 3.356 & 10.272 & 0.404 \\ \mathrm{H} & 3.819 & 9.937 & 2.084 \\ \mathrm{H} & 2.114 & 10.214 & 1.680\end{array}$

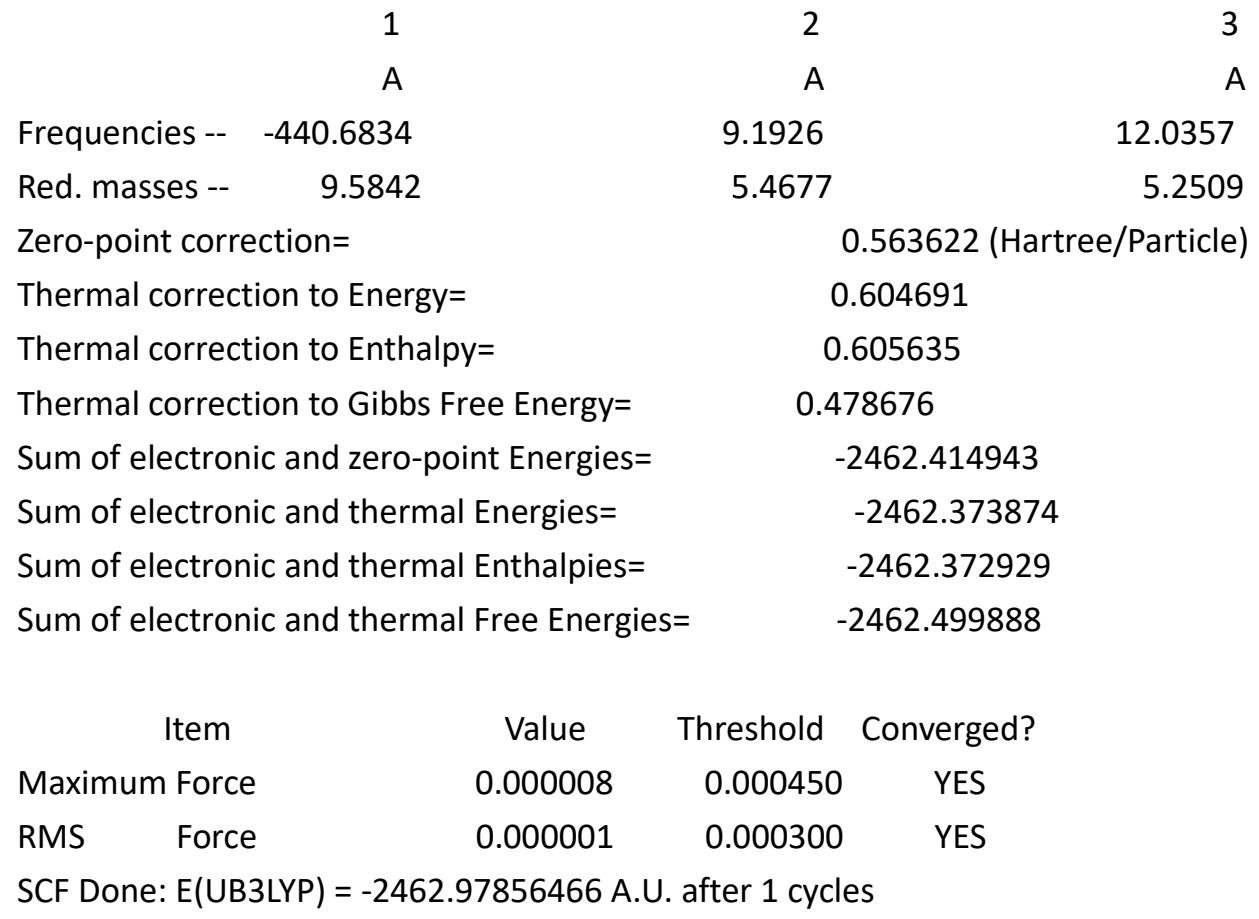


G2C

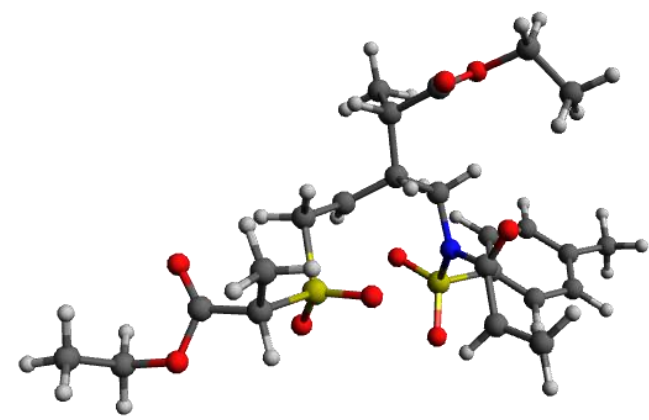

Cartesian coordinates (Angstroms):

70

$\begin{array}{llll}\text { C } & -5.045 & 4.143 & 3.652\end{array}$

$\begin{array}{llll}\text { H } & -4.038 & 4.180 & 4.081\end{array}$

$\begin{array}{llll}\text { C } & -5.048 & 4.784 & 2.258\end{array}$

$\begin{array}{llll}\text { H } & -4.781 & 5.842 & 2.354\end{array}$

$\begin{array}{llll}\text { C } & -6.414 & 4.814 & 1.577\end{array}$

$\begin{array}{llll}0 & -6.747 & 5.679 & 0.795\end{array}$

$\begin{array}{llll}0 & -7.192 & 3.760 & 1.917\end{array}$

$\begin{array}{llll}\text { C } & -8.480 & 3.663 & 1.254\end{array}$

$\begin{array}{llll}\mathrm{H} & -8.836 & 4.672 & 1.038\end{array}$

$\begin{array}{llll}\text { C } & -8.375 & 2.827 & -0.012\end{array}$

$\begin{array}{llll}\mathrm{H} & -7.665 & 3.272 & -0.715\end{array}$

$\begin{array}{llll}H & -8.040 & 1.809 & 0.218\end{array}$

$\begin{array}{llll}H & -9.356 & 2.764 & -0.496\end{array}$

$\begin{array}{llll}H & -9.134 & 3.196 & 1.995\end{array}$

$\begin{array}{llll}H & -5.719 & 4.681 & 4.326\end{array}$

$\begin{array}{llll}\text { H } & -5.374 & 3.101 & 3.625\end{array}$

$\begin{array}{llll}\text { C } & -3.616 & 1.887 & -3.670\end{array}$

$\begin{array}{llll}\text { C } & -3.029 & 2.010 & -2.476\end{array}$

$\begin{array}{llll}\text { C } & -3.861 & 2.325 & -1.284\end{array}$

$\begin{array}{llll}\text { O } & -4.978 & 2.813 & -1.382\end{array}$ 


\begin{tabular}{|c|c|c|c|}
\hline $\mathrm{N}$ & -3.334 & 2.109 & 0.019 \\
\hline$S$ & -2.164 & 0.905 & 0.437 \\
\hline O & -1.188 & 0.809 & -0.644 \\
\hline O & -1.752 & 1.218 & 1.806 \\
\hline C & -3.096 & -0.628 & 0.483 \\
\hline C & -3.370 & -1.303 & -0.710 \\
\hline C & -4.099 & -2.487 & -0.662 \\
\hline C & -4.555 & -3.014 & 0.557 \\
\hline C & -4.258 & -2.319 & 1.736 \\
\hline C & -3.531 & -1.129 & 1.710 \\
\hline C & -5.322 & -4.314 & 0.592 \\
\hline C & -4.161 & 2.639 & 1.130 \\
\hline C & -3.991 & 4.166 & 1.263 \\
\hline C & -2.592 & 4.539 & 1.653 \\
\hline C & -1.987 & 5.808 & 1.208 \\
\hline$S$ & -1.028 & 5.516 & -0.378 \\
\hline $\mathrm{O}$ & -1.987 & 5.119 & -1.427 \\
\hline 0 & 0.131 & 4.666 & -0.065 \\
\hline C & -0.349 & 7.167 & -0.904 \\
\hline C & 0.687 & 7.621 & 0.109 \\
\hline C & -1.452 & 8.203 & -1.126 \\
\hline 0 & 0.412 & 7.971 & 1.241 \\
\hline $\mathrm{O}$ & 1.922 & 7.591 & -0.408 \\
\hline C & 3.013 & 7.964 & 0.477 \\
\hline C & 3.227 & 9.470 & 0.484 \\
\hline $\mathrm{H}$ & -4.691 & 1.995 & -3.781 \\
\hline $\mathrm{H}$ & -3.034 & 1.689 & -4.565 \\
\hline $\mathrm{H}$ & -1.960 & 1.913 & -2.348 \\
\hline $\mathrm{H}$ & -3.013 & -0.911 & -1.656 \\
\hline $\mathrm{H}$ & -4.315 & -3.016 & -1.588 \\
\hline $\mathrm{H}$ & -4.596 & -2.714 & 2.690 \\
\hline $\mathrm{H}$ & -3.286 & -0.603 & 2.626 \\
\hline $\mathrm{H}$ & -6.065 & -4.361 & -0.212 \\
\hline $\mathrm{H}$ & -5.843 & -4.448 & 1.545 \\
\hline $\mathrm{H}$ & -4.649 & -5.171 & 0.460 \\
\hline $\mathrm{H}$ & -3.838 & 2.150 & 2.048 \\
\hline $\mathrm{H}$ & -5.204 & 2.384 & 0.940 \\
\hline $\mathrm{H}$ & -4.210 & 4.614 & 0.286 \\
\hline $\mathrm{H}$ & -1.955 & 3.811 & 2.147 \\
\hline $\mathrm{H}$ & -1.245 & 6.223 & 1.895 \\
\hline $\mathrm{H}$ & -2.730 & 6.571 & 0.955 \\
\hline $\mathrm{H}$ & 0.143 & 6.902 & -1.845 \\
\hline $\mathrm{H}$ & -2.247 & 7.781 & -1.748 \\
\hline $\mathrm{H}$ & -1.038 & 9.076 & -1.642 \\
\hline
\end{tabular}




$\begin{array}{cccc}\mathrm{H} & -1.872 & 8.542 & -0.175 \\ \mathrm{H} & 3.876 & 7.434 & 0.069 \\ \mathrm{H} & 2.792 & 7.585 & 1.477 \\ \mathrm{H} & 3.402 & 9.844 & -0.530 \\ \mathrm{H} & 4.102 & 9.715 & 1.096 \\ \mathrm{H} & 2.358 & 9.982 & 0.907\end{array}$

1

A

Frequencies -- $\quad 8.8381$

5.3633

Red. masses --

Zero-point correction=

Thermal correction to Energy=

Thermal correction to Enthalpy=

Thermal correction to Gibbs Free Energy=

Sum of electronic and zero-point Energies=

Sum of electronic and thermal Energies=

Sum of electronic and thermal Enthalpies=

Sum of electronic and thermal Free Energies=
2

A

12.0221

5.3190

16.2102

4.9037

0.566575 (Hartree/Particle)

0.607307

0.608251

0.483402

$-2462.445381$

$-2462.404649$

$-2462.403705$

$-2462.528554$

\begin{tabular}{|c|c|c|c|}
\hline Item & Value & Threshold & Converged? \\
\hline Maximum Force & 0.000016 & 0.000450 & YES \\
\hline Force & 0.000002 & 0.000300 & YES \\
\hline
\end{tabular}

SCF Done: $E(U B 3 L Y P)=-2463.01195605$ A.U. after 1 cycles

TS2C

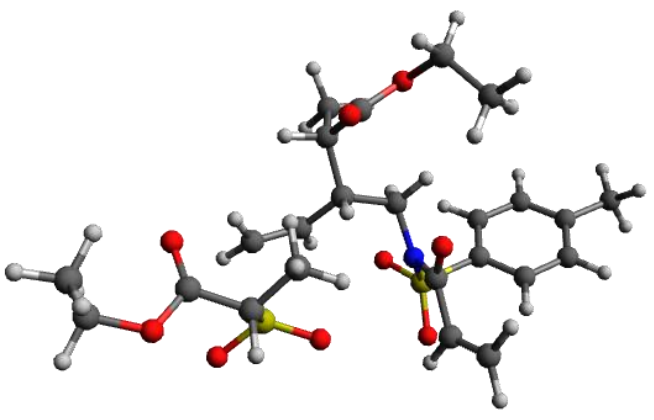


Cartesian coordinates (Angstroms):

70

$\begin{array}{llll}H & -6.037 & -2.739 & 2.712\end{array}$

$\begin{array}{llll}H & -4.088 & -1.197 & 2.782\end{array}$

$\begin{array}{llll}\mathrm{H} & -3.595 & 3.386 & 4.540\end{array}$

$\begin{array}{llll}\text { C } & -5.599 & -2.382 & 1.783\end{array}$

$\begin{array}{llll}\text { C } & -4.510 & -1.511 & 1.834\end{array}$

$\begin{array}{llll}O & -2.088 & 0.142 & 2.076\end{array}$

$\begin{array}{llll}H & -1.506 & 2.556 & 2.434\end{array}$

$\begin{array}{llll}H & -8.084 & -3.396 & -0.164\end{array}$

$\begin{array}{llll}\mathrm{H} & -0.038 & 4.516 & 2.640\end{array}$

$\begin{array}{llll}\text { C } & -4.523 & 3.723 & 4.066\end{array}$

$\begin{array}{llll}\mathrm{H} & -5.042 & 4.381 & 4.771\end{array}$

$\begin{array}{llll}H & -5.164 & 2.854 & 3.899\end{array}$

$\begin{array}{llll}\text { C } & -1.893 & 3.545 & 2.199\end{array}$

$\begin{array}{llll}H & -7.743 & -3.909 & 1.498\end{array}$

$\begin{array}{llll}\mathrm{H} & -3.879 & 1.628 & 2.307\end{array}$

$\begin{array}{llll}\text { C } & -7.300 & -3.763 & 0.509\end{array}$

$\begin{array}{llll}C & -6.132 & -2.808 & 0.561\end{array}$

$\begin{array}{llll}C & -1.013 & 4.624 & 2.171\end{array}$

$\begin{array}{llll}\text { C } & -3.949 & -1.061 & 0.640\end{array}$

$\begin{array}{llll}\mathrm{S} & -2.545 & 0.054 & 0.688\end{array}$

$\begin{array}{llll}H & -3.625 & 5.366 & 3.003\end{array}$

$\begin{array}{llll}\text { C } & -4.205 & 4.468 & 2.764\end{array}$

$\begin{array}{llll}C & -3.942 & 2.275 & 1.433\end{array}$

$\begin{array}{llll}\text { C } & -3.325 & 3.652 & 1.748\end{array}$

$\begin{array}{llll}0 & -1.629 & -0.320 & -0.385\end{array}$

$\begin{array}{llll}H & -6.989 & -4.746 & 0.134\end{array}$

$\begin{array}{llll}\mathrm{H} & -1.392 & 5.646 & 2.163\end{array}$

$\begin{array}{llll}C & -5.542 & -2.340 & -0.625\end{array}$

$\begin{array}{llll}\mathrm{N} & -3.223 & 1.603 & 0.323\end{array}$

$\begin{array}{llll}C & -4.454 & -1.475 & -0.597\end{array}$

$\begin{array}{llll}\mathrm{H} & -4.991 & 2.384 & 1.152\end{array}$

$\begin{array}{llll}\text { C } & -5.420 & 5.007 & 2.015\end{array}$

$\begin{array}{llll}\mathrm{O} & -6.542 & 4.286 & 2.236\end{array}$

$\begin{array}{llll}\mathrm{H} & -3.345 & 4.232 & 0.819\end{array}$

$\mathrm{H} \quad-5.938 \quad-2.665 \quad-1.584$

$\begin{array}{llll}\mathrm{H} & -3.998 & -1.129 & -1.520\end{array}$

$\begin{array}{llll}\mathrm{H} & -1.734 & 1.180 & -1.962\end{array}$

$\begin{array}{llll}\text { C } & -3.485 & 2.112 & -0.974\end{array}$ 


$\begin{array}{cccc}\mathrm{O} & -5.366 & 5.964 & 1.270 \\ \mathrm{H} & -8.559 & 4.415 & 2.140 \\ \mathrm{C} & -7.722 & 4.677 & 1.487 \\ \mathrm{C} & -2.705 & 1.619 & -2.140 \\ \mathrm{O} & -4.334 & 2.988 & -1.086 \\ \mathrm{H} & -7.698 & 5.759 & 1.341 \\ \mathrm{H} & -7.841 & 2.855 & 0.318 \\ \mathrm{C} & -7.789 & 3.938 & 0.160 \\ \mathrm{C} & -3.208 & 1.762 & -3.370 \\ \mathrm{H} & -6.909 & 4.157 & -0.452 \\ \mathrm{H} & -2.650 & 1.440 & -4.245 \\ \mathrm{H} & -8.684 & 4.247 & -0.392 \\ \mathrm{H} & -4.183 & 2.212 & -3.531 \\ \mathrm{~S} & -0.125 & 4.763 & 0.075 \\ \mathrm{O} & -0.643 & 3.653 & -0.758 \\ \mathrm{O} & 1.336 & 4.957 & 0.232 \\ \mathrm{C} & -0.757 & 6.342 & -0.748 \\ \mathrm{C} & -0.265 & 7.515 & 0.074 \\ \mathrm{C} & -2.273 & 6.323 & -0.922 \\ \mathrm{O} & -0.668 & 7.771 & 1.193 \\ \mathrm{O} & 0.664 & 8.222 & -0.586 \\ \mathrm{C} & 1.250 & 9.350 & 0.116 \\ \mathrm{C} & 0.411 & 10.606 & -0.061 \\ \mathrm{H} & -0.236 & 6.308 & -1.709 \\ \mathrm{H} & -2.594 & 5.391 & -1.394 \\ \mathrm{H} & -2.573 & 7.155 & -1.571 \\ \mathrm{H} & -2.798 & 6.443 & 0.030 \\ \mathrm{H} & 2.238 & 9.458 & -0.336 \\ \mathrm{H} & 1.359 & 9.085 & 1.170 \\ \mathrm{H} & 0.271 & 10.836 & -1.122 \\ \mathrm{H} & 0.915 & 11.457 & 0.411 \\ \mathrm{H} & -0.570 & 10.486 & 0.409\end{array}$

\section{1}

A

2

3

A

A

Frequencies -- -279.5734

11.4819

12.9663

Red. masses -- 9.5038

4.3467

4.8069

Zero-point correction=

Thermal correction to Energy=

0.565271 (Hartree/Particle)

0.605747

0.606692

Thermal correction to Enthalpy=

0.483671

Sum of electronic and zero-point Energies=

$-2462.442519$

$-2462.402042$

Sum of electronic and thermal Energies=

Sum of electronic and thermal Enthalpies=

$-2462.401098$ 


\begin{tabular}{|c|c|c|c|}
\hline Item & Value & Threshold & Converged? \\
\hline Maximum Force & 0.000007 & 0.000450 & YES \\
\hline Force & 0.000001 & 0.000300 & YES \\
\hline
\end{tabular}

SCF Done: $E(U B 3 L Y P)=-2463.00778954$ A.U. after 1 cycles

G3Csm

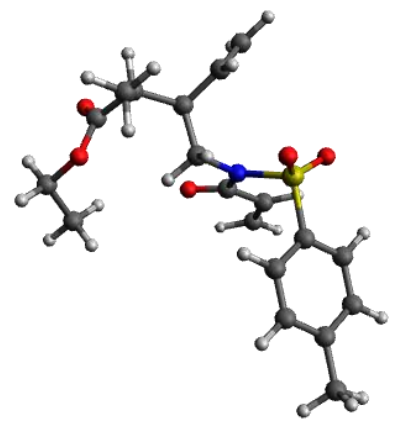

Cartesian coordinates (Angstroms):

51

$\begin{array}{llll}\text { C } & -4.316 & 4.919 & 4.120\end{array}$

$\begin{array}{llll}\mathrm{H} & -3.597 & 4.502 & 4.833\end{array}$

$\begin{array}{llll}\text { C } & -3.603 & 5.365 & 2.835\end{array}$

$\begin{array}{llll}H & -2.877 & 6.146 & 3.084\end{array}$

$\begin{array}{llll}\text { C } & -4.523 & 6.027 & 1.811\end{array}$

$\begin{array}{llll}0 & -4.149 & 6.869 & 1.023\end{array}$

$\begin{array}{llll}0 & -5.792 & 5.554 & 1.863\end{array}$

$\begin{array}{llll}\text { C } & -6.722 & 6.085 & 0.884\end{array}$

$\begin{array}{llll}\text { H } & -6.434 & 7.113 & 0.655\end{array}$

$\begin{array}{llll}\text { C } & -6.744 & 5.223 & -0.368\end{array}$

$\begin{array}{llll}\mathrm{H} & -5.753 & 5.180 & -0.828\end{array}$

$\begin{array}{llll}H & -7.060 & 4.201 & -0.135\end{array}$ 


\begin{tabular}{cccc} 
H & -7.450 & 5.642 & -1.094 \\
H & -7.689 & 6.082 & 1.395 \\
H & -4.805 & 5.772 & 4.602 \\
H & -5.086 & 4.169 & 3.925 \\
C & -2.479 & 1.759 & -2.785 \\
C & -2.288 & 1.554 & -1.479 \\
C & -3.012 & 2.405 & -0.494 \\
O & -3.631 & 3.404 & -0.837 \\
N & -2.985 & 2.065 & 0.876 \\
S & -2.350 & 0.590 & 1.526 \\
O & -1.001 & 0.369 & 1.005 \\
O & -2.592 & 0.675 & 2.967 \\
$\mathrm{C}$ & -3.421 & -0.681 & 0.851 \\
$\mathrm{C}$ & -2.871 & -1.696 & 0.071 \\
$\mathrm{C}$ & -3.704 & -2.707 & -0.411 \\
$\mathrm{C}$ & -5.073 & -2.719 & -0.122 \\
$\mathrm{C}$ & -5.597 & -1.687 & 0.674 \\
$\mathrm{C}$ & -4.783 & -0.674 & 1.167 \\
$\mathrm{C}$ & -5.969 & -3.822 & -0.633 \\
$\mathrm{C}$ & -3.652 & 3.011 & 1.802 \\
$\mathrm{C}$ & -2.772 & 4.242 & 2.119 \\
$\mathrm{C}$ & -1.554 & 3.860 & 2.923 \\
$\mathrm{C}$ & -0.300 & 4.109 & 2.544 \\
$\mathrm{H}$ & -3.162 & 2.529 & -3.132 \\
$\mathrm{H}$ & -1.955 & 1.170 & -3.531 \\
$\mathrm{H}$ & -1.593 & 0.806 & -1.122 \\
$\mathrm{H}$ & -1.809 & -1.693 & -0.148 \\
$\mathrm{H}$ & -3.278 & -3.499 & -1.021 \\
$\mathrm{H}$ & -6.658 & -1.681 & 0.913 \\
$\mathrm{H}$ & -5.200 & 0.110 & 1.791 \\
$\mathrm{H}$ & -5.459 & -4.441 & -1.377 \\
$\mathrm{H}$ & -6.877 & -3.416 & -1.094 \\
$\mathrm{H}$ & -6.289 & -4.480 & 0.185 \\
$\mathrm{H}$ & -3.888 & 2.465 & 2.714 \\
$\mathrm{H}$ & -4.582 & 3.322 & 1.324 \\
& -2.438 & 4.669 & 1.168 \\
$\mathrm{H}$ & -1.731 & 3.334 & 3.861 \\
\hline & & 3.815 & 3.153 \\
\hline
\end{tabular}

1

A

Frequencies -- $\quad 11.7413$

Red. masses -- 4.4186

\section{2}

A 18.6815

3.6540
3

A 22.0524 4.0525 
Zero-point correction=

Thermal correction to Energy=

Thermal correction to Enthalpy=

Thermal correction to Gibbs Free Energy=

Sum of electronic and zero-point Energies=

Sum of electronic and thermal Energies=

Sum of electronic and thermal Enthalpies=

Sum of electronic and thermal Free Energies=
0.417766 (Hartree/Particle)

0.446104

0.447048

0.353642

$-1567.630933$

$-1567.602595$

$-1567.601651$

$-1567.695057$

\begin{tabular}{|c|c|c|c|}
\hline Item & Value & Threshold & Converged? \\
\hline Maximum Force & 0.000017 & 0.000450 & YES \\
\hline Force & 0.000002 & 0.000300 & YES \\
\hline
\end{tabular}

SCF Done: $E(R B 3 L Y P)=-1568.04869929$ A.U. after 1 cycles

cta

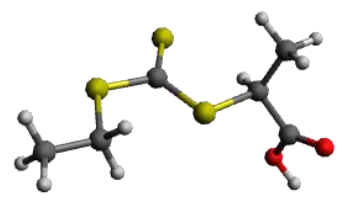

Cartesian coordinates (Angstroms):

21

$\begin{array}{llll}\text { S } & 2.935 & 5.319 & -5.146 \\ \text { C } & 4.496 & 5.524 & -5.646 \\ \text { S } & 5.776 & 5.343 & -4.451 \\ \text { C } & 7.386 & 5.606 & -5.320\end{array}$




$\begin{array}{llll}\mathrm{C} & 8.510 & 5.442 & -4.294 \\ \mathrm{H} & 8.424 & 6.173 & -3.484 \\ \mathrm{H} & 9.476 & 5.594 & -4.786 \\ \mathrm{H} & 8.508 & 4.439 & -3.855 \\ \mathrm{H} & 7.400 & 6.609 & -5.756 \\ \mathrm{H} & 7.483 & 4.873 & -6.126 \\ \mathrm{~S} & 5.046 & 5.929 & -7.287 \\ \mathrm{C} & 3.467 & 6.055 & -8.244 \\ \mathrm{H} & 2.763 & 5.403 & -7.718 \\ \mathrm{C} & 2.956 & 7.492 & -8.317 \\ \mathrm{H} & 2.778 & 7.878 & -7.310 \\ \mathrm{H} & 2.010 & 7.519 & -8.870 \\ \mathrm{H} & 3.671 & 8.135 & -8.834 \\ \mathrm{C} & 3.758 & 5.478 & -9.623 \\ \mathrm{O} & 3.627 & 4.133 & -9.639 \\ \mathrm{H} & 3.852 & 3.845 & -10.545 \\ \mathrm{O} & 4.067 & 6.128 & -10.597\end{array}$

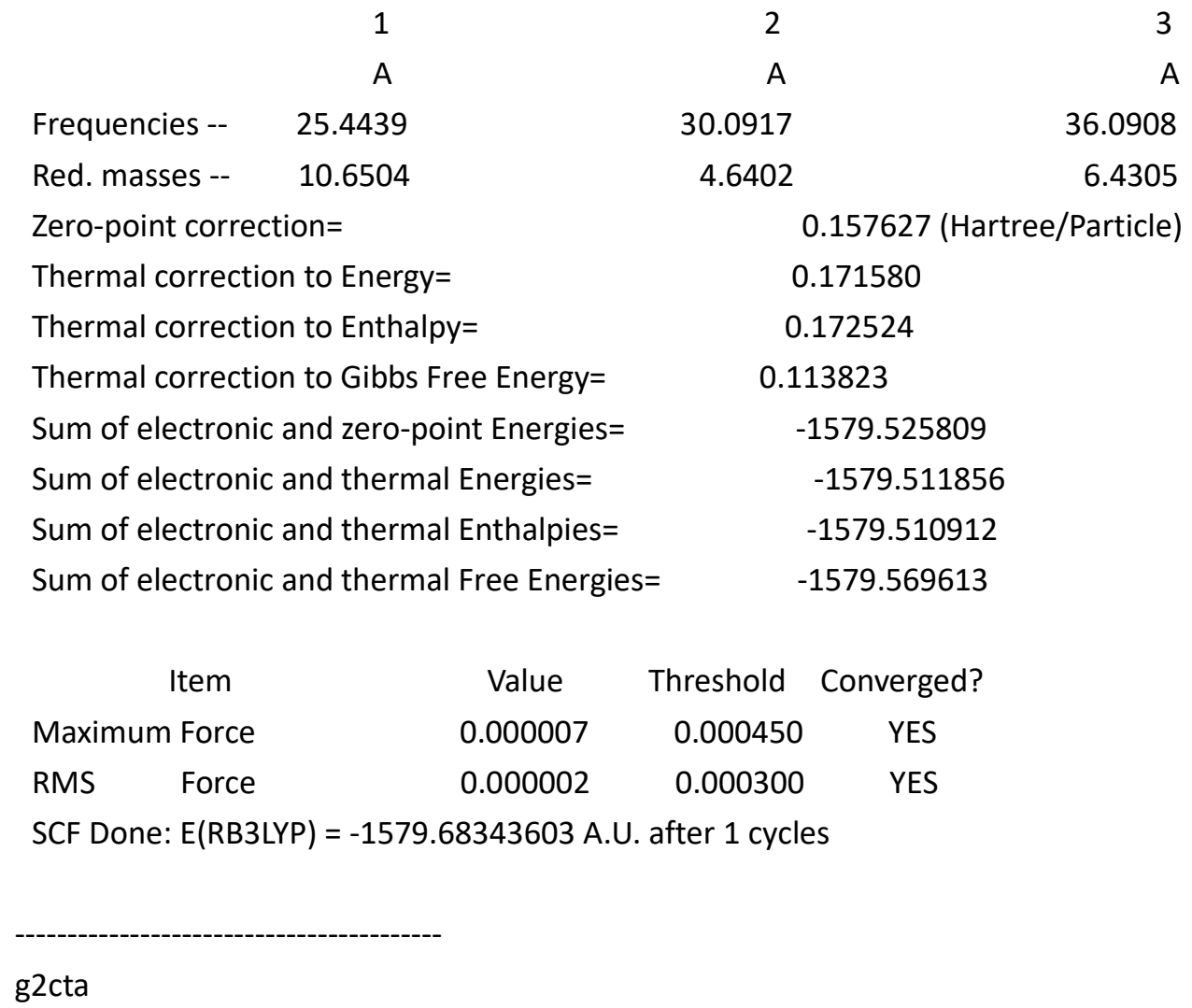




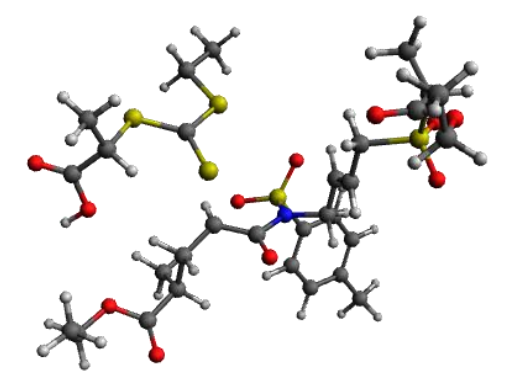

Cartesian coordinates (Angstroms):

91

$\begin{array}{llll}\mathrm{O} & 3.734 & 5.705 & -10.541 \\ \mathrm{C} & 3.320 & 5.417 & -9.442 \\ \mathrm{O} & 2.694 & 4.250 & -9.165 \\ \mathrm{H} & 2.687 & 3.714 & -9.980 \\ \mathrm{C} & 3.425 & 6.297 & -8.204 \\ \mathrm{C} & 3.464 & 7.781 & -8.561 \\ \mathrm{~S} & 4.968 & 5.787 & -7.309 \\ \mathrm{C} & 4.415 & 5.390 & -5.663 \\ \mathrm{~S} & 2.834 & 5.209 & -5.140 \\ \mathrm{~S} & 5.673 & 5.051 & -4.484 \\ \mathrm{C} & 7.292 & 5.155 & -5.363 \\ \mathrm{C} & 8.394 & 4.808 & -4.360 \\ \mathrm{H} & 2.603 & 6.059 & -7.522 \\ \mathrm{H} & 4.298 & 8.004 & -9.231 \\ \mathrm{H} & 3.557 & 8.386 & -7.655 \\ \mathrm{H} & 2.537 & 8.062 & -9.074 \\ \mathrm{H} & 7.424 & 6.165 & -5.762 \\ \mathrm{H} & 7.288 & 4.447 & -6.197 \\ \mathrm{H} & 8.413 & 5.514 & -3.524 \\ \mathrm{H} & 9.368 & 4.850 & -4.861 \\ \mathrm{H} & 8.262 & 3.800 & -3.956\end{array}$




\begin{tabular}{|c|c|c|c|}
\hline C & 1.379 & 2.739 & -6.343 \\
\hline C & 2.352 & 2.859 & -5.203 \\
\hline C & 1.824 & 2.711 & -3.841 \\
\hline O & 0.663 & 2.999 & -3.565 \\
\hline$N$ & 2.693 & 2.341 & -2.763 \\
\hline$S$ & 4.128 & 1.421 & -2.826 \\
\hline O & 4.421 & 1.109 & -4.228 \\
\hline O & 5.122 & 2.096 & -1.987 \\
\hline C & 3.674 & -0.110 & -2.005 \\
\hline C & 2.764 & -0.978 & -2.616 \\
\hline C & 2.443 & -2.175 & -1.986 \\
\hline C & 3.020 & -2.526 & -0.754 \\
\hline C & 3.937 & -1.643 & -0.171 \\
\hline C & 4.269 & -0.435 & -0.787 \\
\hline C & 2.641 & -3.817 & -0.069 \\
\hline C & 2.228 & 2.693 & -1.394 \\
\hline C & 2.611 & 4.098 & -1.023 \\
\hline C & 1.720 & 5.052 & -0.742 \\
\hline C & 2.108 & 6.448 & -0.367 \\
\hline$S$ & 1.771 & 6.726 & 1.422 \\
\hline O & 2.834 & 6.081 & 2.210 \\
\hline 0 & 0.354 & 6.416 & 1.678 \\
\hline C & 1.970 & 8.553 & 1.688 \\
\hline C & 0.848 & 9.291 & 0.978 \\
\hline C & 3.357 & 9.047 & 1.271 \\
\hline $\mathrm{O}$ & 0.780 & 9.415 & -0.230 \\
\hline 0 & -0.040 & 9.784 & 1.851 \\
\hline C & -1.192 & 10.474 & 1.295 \\
\hline C & -0.883 & 11.940 & 1.035 \\
\hline $\mathrm{H}$ & 0.439 & 3.226 & -6.065 \\
\hline $\mathrm{H}$ & 1.785 & 3.244 & -7.222 \\
\hline $\mathrm{H}$ & 3.376 & 2.562 & -5.378 \\
\hline $\mathrm{H}$ & 2.317 & -0.724 & -3.572 \\
\hline $\mathrm{H}$ & 1.736 & -2.852 & -2.458 \\
\hline $\mathrm{H}$ & 4.401 & -1.901 & 0.777 \\
\hline $\mathrm{H}$ & 4.985 & 0.245 & -0.338 \\
\hline $\mathrm{H}$ & 2.560 & -4.641 & -0.787 \\
\hline $\mathrm{H}$ & 1.667 & -3.725 & 0.429 \\
\hline $\mathrm{H}$ & 3.374 & -4.098 & 0.692 \\
\hline $\mathrm{H}$ & 2.669 & 1.981 & -0.691 \\
\hline $\mathrm{H}$ & 1.146 & 2.557 & -1.379 \\
\hline $\mathrm{H}$ & 3.679 & 4.308 & -1.003 \\
\hline $\mathrm{H}$ & 0.655 & 4.836 & -0.770 \\
\hline $\mathrm{H}$ & 1.526 & 7.209 & -0.896 \\
\hline
\end{tabular}




$\begin{array}{lrrr}\mathrm{H} & 3.176 & 6.632 & -0.511 \\ \mathrm{H} & 1.832 & 8.626 & 2.770 \\ \mathrm{H} & 4.131 & 8.415 & 1.712 \\ \mathrm{H} & 3.504 & 10.072 & 1.628 \\ \mathrm{H} & 3.462 & 9.052 & 0.182 \\ \mathrm{H} & -1.964 & 10.351 & 2.057 \\ \mathrm{H} & -1.496 & 9.959 & 0.382 \\ \mathrm{H} & -0.537 & 12.434 & 1.949 \\ \mathrm{H} & -1.789 & 12.451 & 0.691 \\ \mathrm{H} & -0.117 & 12.043 & 0.262 \\ \mathrm{C} & 1.071 & 1.257 & -6.733 \\ \mathrm{C} & 2.324 & 0.472 & -7.159 \\ \mathrm{C} & 0.011 & 1.264 & -7.826 \\ \mathrm{O} & -1.148 & 0.942 & -7.673 \\ \mathrm{O} & 0.516 & 1.701 & -9.010 \\ \mathrm{C} & -0.421 & 1.819 & -10.107 \\ \mathrm{C} & -1.102 & 3.180 & -10.096 \\ \mathrm{H} & 0.594 & 0.765 & -5.880 \\ \mathrm{H} & 2.831 & 0.969 & -7.992 \\ \mathrm{H} & 2.060 & -0.542 & -7.481 \\ \mathrm{H} & 3.031 & 0.390 & -6.328 \\ \mathrm{H} & -1.150 & 1.009 & -10.038 \\ \mathrm{H} & 0.189 & 1.682 & -11.005 \\ \mathrm{H} & -1.733 & 3.284 & -9.209 \\ \mathrm{H} & -1.734 & 3.291 & -10.985 \\ \mathrm{H} & -0.359 & 3.985 & -10.096\end{array}$

\section{1}

A

Frequencies -- -217.4285

Red. masses -- 14.6899

Zero-point correction=

Thermal correction to Energy=

Thermal correction to Enthalpy=

Thermal correction to Gibbs Free Energy=

Sum of electronic and zero-point Energies=

Sum of electronic and thermal Energies=

Sum of electronic and thermal Enthalpies=

Sum of electronic and thermal Free Energies=
2

A

4.7891

6.2929

0.726185 (Hartree/Particle)

0.782016

0.782960

0.617803

$-4041.978537$

$-4041.922705$

$-4041.921761$

$-4042.086918$

\begin{tabular}{lccc}
\multicolumn{1}{c}{ Item } & Value & Threshold & Converged? \\
Maximum Force & 0.000011 & 0.000450 & YES \\
RMS $\quad$ Force & 0.000001 & 0.000300 & YES \\
SCF Done: & E(UB3LYP $)=-4042.70472153$ & A.U. & after 1 cycles
\end{tabular}


g3cta

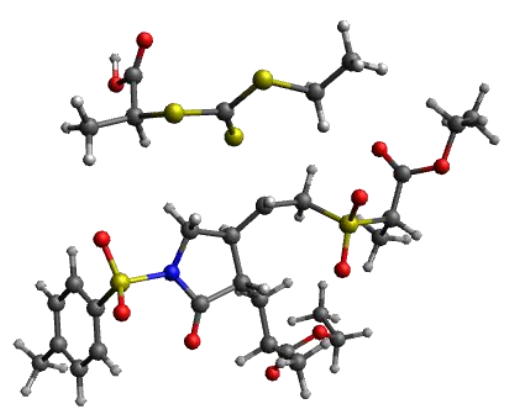

Cartesian coordinates (Angstroms):

91

$\begin{array}{llll}\text { O } & -7.850 & 6.699 & 5.520 \\ \text { C } & -6.663 & 6.893 & 5.624 \\ \text { O } & -5.857 & 6.129 & 6.407 \\ \text { H } & -6.437 & 5.461 & 6.819 \\ \text { C } & -5.841 & 8.005 & 4.977 \\ \text { C } & -5.545 & 9.129 & 5.988 \\ \text { S } & -6.697 & 8.744 & 3.532 \\ \text { C } & -6.688 & 7.431 & 2.329 \\ \text { S } & -5.461 & 6.308 & 2.124 \\ \text { S } & -8.133 & 7.592 & 1.338 \\ \text { C } & -7.833 & 6.513 & -0.121 \\ \text { C } & -9.110 & 6.460 & -0.961 \\ \text { H } & -4.900 & 7.569 & 4.635 \\ \text { H } & -6.466 & 9.631 & 6.303 \\ \text { H } & -4.862 & 9.860 & 5.550 \\ \text { H } & -5.066 & 8.698 & 6.873 \\ \text { H } & -7.555 & 5.522 & 0.244 \\ \text { H } & -7.003 & 6.922 & -0.703\end{array}$




\begin{tabular}{|c|c|c|c|}
\hline $\mathrm{H}$ & -9.950 & 6.041 & -0.397 \\
\hline $\mathrm{H}$ & -8.935 & 5.824 & -1.836 \\
\hline $\mathrm{H}$ & -9.398 & 7.453 & -1.324 \\
\hline C & -0.407 & 6.960 & -0.088 \\
\hline C & -1.395 & 8.024 & 0.430 \\
\hline C & -0.756 & 9.032 & 1.392 \\
\hline O & 0.298 & 9.620 & 1.240 \\
\hline$N$ & -1.593 & 9.166 & 2.493 \\
\hline$S$ & -1.369 & 10.355 & 3.726 \\
\hline O & -1.203 & 11.661 & 3.099 \\
\hline O & -2.479 & 10.091 & 4.649 \\
\hline C & 0.158 & 9.881 & 4.520 \\
\hline C & 1.374 & 10.361 & 4.029 \\
\hline C & 2.548 & 10.004 & 4.687 \\
\hline C & 2.527 & 9.181 & 5.822 \\
\hline C & 1.289 & 8.724 & 6.296 \\
\hline C & 0.102 & 9.068 & 5.654 \\
\hline C & 3.814 & 8.784 & 6.505 \\
\hline C & -2.864 & 8.439 & 2.371 \\
\hline C & -2.589 & 7.411 & 1.247 \\
\hline C & -3.844 & 7.087 & 0.474 \\
\hline C & -3.851 & 5.954 & -0.512 \\
\hline$S$ & -3.920 & 6.609 & -2.237 \\
\hline O & -2.691 & 7.374 & -2.521 \\
\hline O & -5.237 & 7.253 & -2.407 \\
\hline C & -3.876 & 5.143 & -3.372 \\
\hline C & -5.178 & 4.367 & -3.251 \\
\hline C & -2.646 & 4.264 & -3.128 \\
\hline O & -5.524 & 3.786 & -2.241 \\
\hline $\mathrm{O}$ & -5.868 & 4.397 & -4.398 \\
\hline C & -7.137 & 3.687 & -4.422 \\
\hline C & -6.940 & 2.220 & -4.767 \\
\hline $\mathrm{H}$ & -0.073 & 6.351 & 0.764 \\
\hline $\mathrm{H}$ & -0.957 & 6.296 & -0.760 \\
\hline $\mathrm{H}$ & -1.782 & 8.599 & -0.421 \\
\hline $\mathrm{H}$ & 1.393 & 10.990 & 3.148 \\
\hline $\mathrm{H}$ & 3.499 & 10.375 & 4.312 \\
\hline $\mathrm{H}$ & 1.253 & 8.098 & 7.183 \\
\hline $\mathrm{H}$ & -0.857 & 8.731 & 6.034 \\
\hline $\mathrm{H}$ & 4.518 & 9.622 & 6.550 \\
\hline $\mathrm{H}$ & 4.312 & 7.971 & 5.960 \\
\hline $\mathrm{H}$ & 3.635 & 8.433 & 7.527 \\
\hline $\mathrm{H}$ & -3.677 & 9.125 & 2.107 \\
\hline $\mathrm{H}$ & -3.119 & 7.959 & 3.314 \\
\hline
\end{tabular}




\begin{tabular}{lrll}
$\mathrm{H}$ & -2.214 & 6.491 & 1.716 \\
$\mathrm{H}$ & -4.451 & 7.945 & 0.188 \\
$\mathrm{H}$ & -4.741 & 5.321 & -0.441 \\
$\mathrm{H}$ & -2.964 & 5.321 & -0.431 \\
$\mathrm{H}$ & -3.823 & 5.633 & -4.348 \\
$\mathrm{H}$ & -1.740 & 4.874 & -3.072 \\
$\mathrm{H}$ & -2.535 & 3.558 & -3.958 \\
$\mathrm{H}$ & -2.756 & 3.684 & -2.207 \\
$\mathrm{H}$ & -7.715 & 4.210 & -5.188 \\
$\mathrm{H}$ & -7.621 & 3.810 & -3.451 \\
$\mathrm{H}$ & -6.412 & 2.110 & -5.719 \\
$\mathrm{H}$ & -7.916 & 1.729 & -4.857 \\
$\mathrm{H}$ & -6.372 & 1.710 & -3.983 \\
$\mathrm{C}$ & 0.844 & 7.474 & -0.844 \\
$\mathrm{C}$ & 0.516 & 8.404 & -2.027 \\
$\mathrm{C}$ & 1.675 & 6.290 & -1.320 \\
$\mathrm{O}$ & 2.830 & 6.084 & -1.016 \\
$\mathrm{O}$ & 0.974 & 5.480 & -2.161 \\
$\mathrm{C}$ & 1.691 & 4.349 & -2.709 \\
$\mathrm{C}$ & 1.665 & 3.157 & -1.763 \\
$\mathrm{H}$ & 1.486 & 8.012 & -0.145 \\
$\mathrm{H}$ & -0.221 & 7.959 & -2.700 \\
$\mathrm{H}$ & 1.424 & 8.631 & -2.598 \\
$\mathrm{H}$ & 0.122 & 9.354 & -1.653 \\
$\mathrm{H}$ & 2.717 & 4.655 & -2.927 \\
$\mathrm{H}$ & 1.173 & 4.127 & -3.646 \\
$\mathrm{H}$ & 2.203 & 3.390 & -0.840 \\
$\mathrm{H}$ & 2.150 & 2.295 & -2.236 \\
$\mathrm{H}$ & 0.636 & 2.877 & -1.513 \\
& & & \\
\hline
\end{tabular}

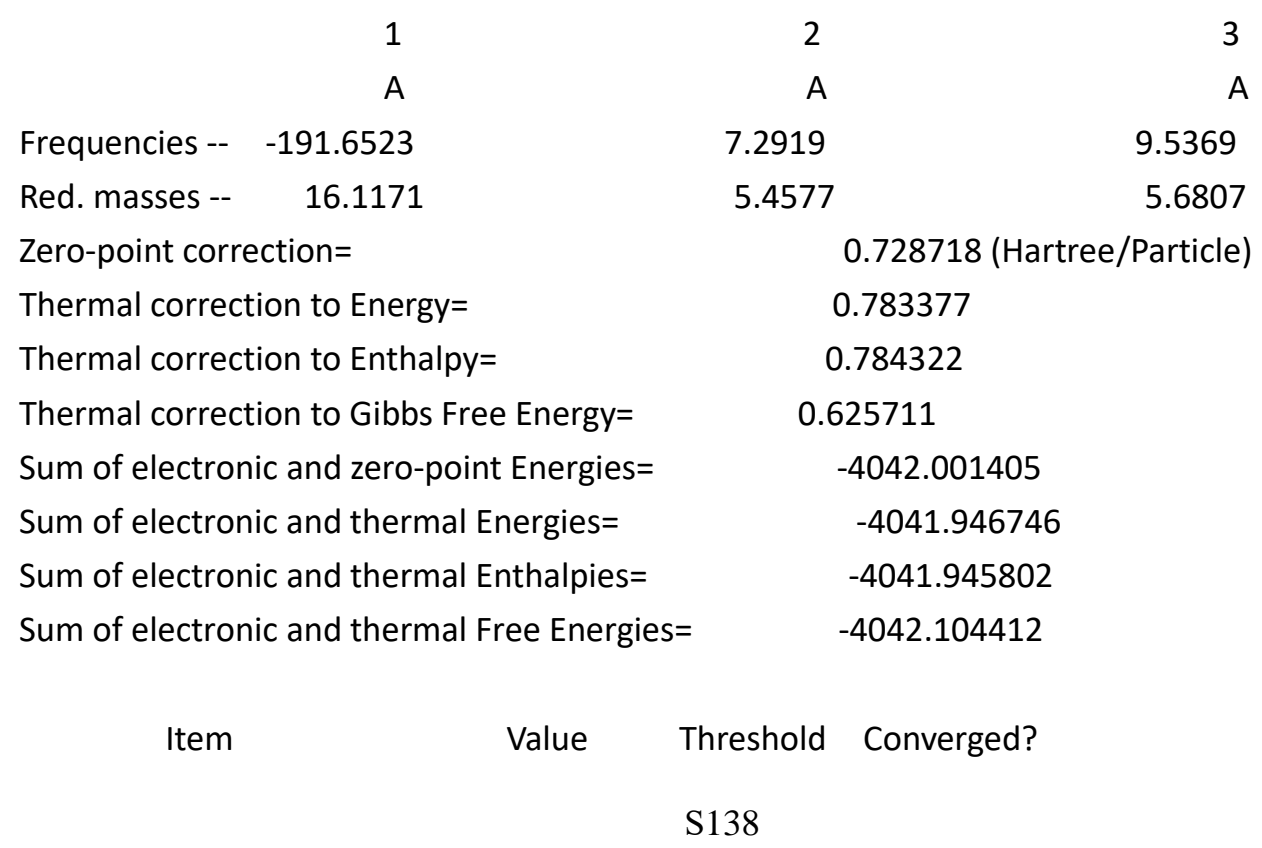




$\begin{array}{lccc}\text { Maximum Force } & 0.000021 & 0.000450 & \text { YES } \\ \text { RMS Force } & 0.000004 & 0.000300 & \text { YES } \\ \text { SCF Done: } E(\text { UB3LYP })=-4042.73012310 \text { A.U. } \text { after 14 cycles } & \end{array}$

sm'

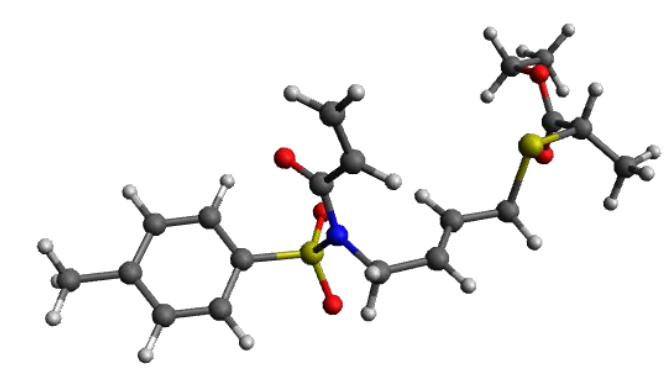

Cartesian coordinates (Angstroms):

52

$\begin{array}{lccc}\text { C } & -6.008 & 2.256 & -2.245 \\ \text { C } & -4.894 & 2.299 & -1.511 \\ \text { C } & -4.216 & 1.024 & -1.126 \\ \text { O } & -4.521 & -0.049 & -1.627 \\ \text { N } & -3.217 & 1.107 & -0.149 \\ \text { S } & -2.223 & -0.309 & 0.133 \\ \text { O } & -1.663 & -0.736 & -1.145 \\ \text { O } & -1.352 & 0.099 & 1.240 \\ \text { C } & -3.328 & -1.572 & 0.758 \\ \text { C } & -3.894 & -2.503 & -0.114 \\ \text { C } & -4.701 & -3.508 & 0.411 \\ \text { C } & -4.953 & -3.596 & 1.789 \\ \text { C } & -4.367 & -2.649 & 2.638 \\ \text { C } & -3.549 & -1.640 & 2.134 \\ \text { C } & -5.819 & -4.704 & 2.339\end{array}$




$\begin{array}{lrrr}\text { C } & -2.876 & 2.335 & 0.584 \\ \text { C } & -1.937 & 3.278 & -0.127 \\ \text { C } & -1.325 & 3.055 & -1.293 \\ \text { C } & -0.384 & 4.026 & -1.937 \\ \text { S } & -1.216 & 4.750 & -3.431 \\ \text { C } & 0.220 & 5.264 & -4.491 \\ \text { C } & 0.961 & 4.014 & -4.937 \\ \text { C } & 1.150 & 6.278 & -3.825 \\ \text { O } & 1.844 & 3.480 & -4.293 \\ \text { O } & 0.495 & 3.558 & -6.114 \\ \text { C } & 1.049 & 2.306 & -6.594 \\ \text { C } & 2.326 & 2.534 & -7.388 \\ \text { H } & -6.431 & 1.304 & -2.550 \\ \text { H } & -6.514 & 3.164 & -2.561 \\ \text { H } & -4.451 & 3.246 & -1.224 \\ \text { H } & -3.709 & -2.426 & -1.178 \\ \text { H } & -5.146 & -4.236 & -0.263 \\ \text { H } & -4.545 & -2.706 & 3.709 \\ \text { H } & -3.074 & -0.926 & 2.799 \\ \text { H } & -6.735 & -4.825 & 1.749 \\ \text { H } & -6.107 & -4.512 & 3.377 \\ \text { H } & -5.291 & -5.666 & 2.314 \\ \text { H } & -2.427 & 2.027 & 1.533 \\ \text { H } & -3.813 & 2.845 & 0.841 \\ \text { H } & -1.752 & 4.208 & 0.412 \\ \text { H } & -1.501 & 2.126 & -1.832 \\ \text { H } & 0.524 & 3.521 & -2.282 \\ \text { H } & -0.107 & 4.828 & -1.248 \\ \text { H } & -0.276 & 5.703 & -5.362 \\ \text { H } & 0.581 & 7.145 & -3.479 \\ \text { H } & 1.910 & 6.620 & -4.537 \\ \text { H } & 1.672 & 5.831 & -2.976 \\ \text { H } & 0.256 & 1.887 & -7.219 \\ \text { H } & 1.223 & 1.650 & -5.739 \\ \text { H } & 2.152 & 3.227 & -8.217 \\ \text { H } & 2.678 & 1.582 & -7.804 \\ & 3.112 & 2.938 & -6.745\end{array}$

\begin{tabular}{lccr} 
& 1 & 2 & 3 \\
& $\mathrm{~A}$ & $\mathrm{~A}$ & $\mathrm{~A}$ \\
Frequencies -- & 8.8745 & 13.7738 & 19.1947 \\
Red. masses -- & 5.0190 & 5.6293 & 5.8222 \\
Zero-point correction $=$ & \multicolumn{2}{c}{0.419112 (Hartree/Particle) } \\
Thermal correction to Energy $=$ & \multicolumn{2}{l}{0.448924}
\end{tabular}


Thermal correction to Enthalpy=

0.449868

Thermal correction to Gibbs Free Energy=

0.352557

Sum of electronic and zero-point Energies=

$-1965.822379$

Sum of electronic and thermal Energies=

$-1965.792568$

Sum of electronic and thermal Enthalpies=

$-1965.791624$

Sum of electronic and thermal Free Energies=

$-1965.888935$

\begin{tabular}{|c|c|c|c|c|}
\hline & Item & Value & Threshold & Converged? \\
\hline Maxir & Force & 0.000010 & 0.000450 & YES \\
\hline RMS & Force & 0.000002 & 0.000300 & YES \\
\hline
\end{tabular}

G4s'

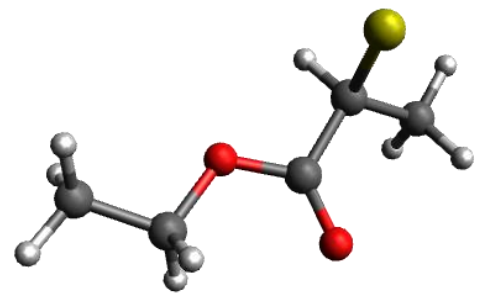

Cartesian coordinates (Angstroms):

17

$\begin{array}{llll}\text { S } & 7.855 & -7.603 & 7.067 \\ \text { C } & 6.489 & -6.385 & 7.150 \\ \text { C } & 5.797 & -6.309 & 5.791 \\ \text { C } & 6.942 & -5.009 & 7.643 \\ \text { O } & 6.060 & -5.489 & 4.938 \\ \text { O } & 4.868 & -7.273 & 5.662 \\ \text { C } & 4.207 & -7.347 & 4.374\end{array}$




$\begin{array}{llll}\mathrm{C} & 3.242 & -8.516 & 4.426 \\ \mathrm{H} & 5.786 & -6.843 & 7.861 \\ \mathrm{H} & 7.442 & -5.098 & 8.611 \\ \mathrm{H} & 6.078 & -4.343 & 7.748 \\ \mathrm{H} & 7.629 & -4.554 & 6.925 \\ \mathrm{H} & 4.970 & -7.475 & 3.599 \\ \mathrm{H} & 3.698 & -6.397 & 4.187 \\ \mathrm{H} & 3.773 & -9.453 & 4.621 \\ \mathrm{H} & 2.721 & -8.607 & 3.466 \\ \mathrm{H} & 2.493 & -8.372 & 5.211\end{array}$

\begin{tabular}{|c|c|c|c|c|}
\hline \multicolumn{2}{|c|}{1} & \multicolumn{2}{|l|}{2} & 3 \\
\hline & $A$ & \multicolumn{2}{|l|}{ A } & A \\
\hline Frequencies -- & 33.5429 & \multicolumn{2}{|l|}{68.9933} & 102.8064 \\
\hline Red. masses -- & 3.3597 & \multicolumn{2}{|l|}{3.7822} & 3.0124 \\
\hline \multicolumn{2}{|c|}{ Zero-point correction $=$} & \multicolumn{3}{|c|}{0.137535 (Hartree/Particle) } \\
\hline \multicolumn{2}{|c|}{ Thermal correction to Energy= } & \multicolumn{2}{|r|}{0.147206} & \\
\hline \multicolumn{2}{|c|}{ Thermal correction to Enthalpy= } & \multicolumn{2}{|c|}{0.148150} & \\
\hline \multicolumn{2}{|c|}{ Thermal correction to Gibbs Free Energy= } & \multicolumn{2}{|c|}{0.100774} & \\
\hline \multicolumn{2}{|c|}{ Sum of electronic and zero-point Energies= } & \multicolumn{2}{|c|}{-744.426349} & \\
\hline \multicolumn{2}{|c|}{ Sum of electronic and thermal Energies= } & \multicolumn{3}{|c|}{-744.416678} \\
\hline \multicolumn{2}{|c|}{ Sum of electronic and thermal Enthalpies= } & \multicolumn{3}{|c|}{-744.415734} \\
\hline \multicolumn{3}{|c|}{ Sum of electronic and thermal Free Energies= } & \multicolumn{2}{|l|}{-744.463109} \\
\hline Item & Value & Threshold & Converged? & \\
\hline Maximum Forc & 0.000027 & 0.000450 & YES & \\
\hline RMS & 0.000004 & 0.000300 & YES & \\
\hline
\end{tabular}

TS1' 


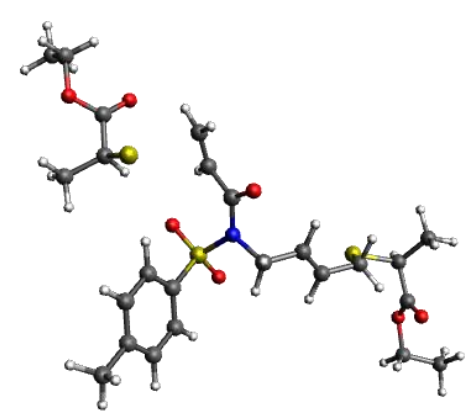

Cartesian coordinates (Angstroms):

69

$\begin{array}{llll}\text { C } & -7.146 & 2.265 & -2.923 \\ \text { C } & -5.845 & 2.330 & -2.535 \\ \text { C } & -5.512 & 2.575 & -1.112 \\ \text { O } & -6.319 & 3.077 & -0.339 \\ \text { N } & -4.203 & 2.318 & -0.642 \\ \text { S } & -3.056 & 1.201 & -1.281 \\ \text { O } & -3.510 & 0.794 & -2.612 \\ \text { O } & -1.736 & 1.799 & -1.090 \\ \text { C } & -3.192 & -0.207 & -0.180 \\ \text { C } & -4.364 & -0.971 & -0.172 \\ \text { C } & -4.436 & -2.078 & 0.668 \\ \text { C } & -3.360 & -2.439 & 1.496 \\ \text { C } & -2.198 & -1.659 & 1.457 \\ \text { C } & -2.104 & -0.543 & 0.625 \\ \text { C } & -3.467 & -3.632 & 2.414 \\ \text { C } & -3.886 & 2.844 & 0.720 \\ \text { C } & -3.670 & 4.332 & 0.713 \\ \text { C } & -2.501 & 4.910 & 1.000 \\ \text { C } & -2.285 & 6.392 & 1.036 \\ \text { S } & -1.143 & 6.864 & -0.348 \\ \text { C } & -0.464 & 8.492 & 0.233\end{array}$




$\begin{array}{cccc}\mathrm{C} & 0.411 & 8.246 & 1.450 \\ \mathrm{C} & -1.533 & 9.552 & 0.498 \\ \mathrm{O} & -0.007 & 8.170 & 2.591 \\ \mathrm{O} & 1.704 & 8.096 & 1.105 \\ \mathrm{C} & 2.632 & 7.772 & 2.170 \\ \mathrm{C} & 3.145 & 9.029 & 2.856 \\ \mathrm{H} & -5.045 & 2.205 & -3.251 \\ \mathrm{H} & -5.204 & -0.715 & -0.811 \\ \mathrm{H} & -5.344 & -2.675 & 0.679 \\ \mathrm{H} & -1.351 & -1.928 & 2.083 \\ \mathrm{H} & -1.200 & 0.056 & 0.588 \\ \mathrm{H} & -3.896 & -4.497 & 1.896 \\ \mathrm{H} & -4.119 & -3.414 & 3.269 \\ \mathrm{H} & -2.489 & -3.923 & 2.810 \\ \mathrm{H} & -2.991 & 2.335 & 1.077 \\ \mathrm{H} & -4.724 & 2.575 & 1.369 \\ \mathrm{H} & -4.542 & 4.939 & 0.476 \\ \mathrm{H} & -1.628 & 4.293 & 1.214 \\ \mathrm{H} & -1.805 & 6.699 & 1.971 \\ \mathrm{H} & -3.234 & 6.927 & 0.931 \\ \mathrm{H} & 0.179 & 8.790 & -0.600 \\ \mathrm{H} & -2.171 & 9.674 & -0.381 \\ \mathrm{H} & -1.063 & 10.517 & 0.725 \\ \mathrm{H} & -6.818 & -0.405 & -8.423 \\ \mathrm{H} & -2.154 & 9.279 & 1.355 \\ \mathrm{H} & 3.437 & 7.230 & 1.668 \\ \mathrm{H} & 2.133 & 7.108 & 2.880 \\ \mathrm{H} & 3.604 & 9.709 & 2.131 \\ \mathrm{H} & 3.901 & 8.761 & 3.603 \\ \mathrm{H} & 2.330 & 9.551 & 3.365 \\ \mathrm{C} & -6.332 & -0.803 & -4.141 \\ \mathrm{C} & -6.046 & -2.310 & -4.098 \\ \mathrm{C} & -6.989 & -0.312 & -5.423 \\ \mathrm{O} & -6.834 & 0.808 & -5.872 \\ \mathrm{O} & -7.786 & -1.244 & -5.978 \\ \mathrm{C} & -8.520 & -0.854 & -7.165 \\ \mathrm{H} & -7.690 & -1.064 & -8.422 \\ \mathrm{H} & -5.507 & -2.559 & -3.180 \\ \mathrm{H} & -6.967 & -2.594 & -4.953 \\ \mathrm{H} & -2.896 & -4.142 \\ \mathrm{H} & 0.189 & -7.060 \\ \mathrm{H} & -8.495\end{array}$




$\begin{array}{llll}\mathrm{S} & -7.410 & -0.329 & -2.715 \\ \mathrm{H} & -5.399 & -0.247 & -4.024 \\ \mathrm{H} & -7.400 & 2.202 & -3.975 \\ \mathrm{H} & -7.942 & 2.445 & -2.208\end{array}$

\begin{tabular}{|c|c|c|c|c|}
\hline \multicolumn{5}{|c|}{1} \\
\hline \multicolumn{2}{|r|}{$A$} & \multicolumn{2}{|l|}{ A } & $A$ \\
\hline \multicolumn{2}{|c|}{ Frequencies -- -112.1098} & \multicolumn{2}{|l|}{6.9094} & 9.6748 \\
\hline \multicolumn{2}{|c|}{ Red. masses -- $\quad 7.4692$} & \multicolumn{2}{|l|}{5.5505} & 5.8883 \\
\hline \multicolumn{4}{|c|}{ Zero-point correction= } & /Particle) \\
\hline \multicolumn{2}{|c|}{ Thermal correction to Energy= } & \multicolumn{3}{|c|}{0.599080} \\
\hline \multicolumn{2}{|c|}{ Thermal correction to Enthalpy= } & \multicolumn{3}{|c|}{0.600024} \\
\hline \multicolumn{2}{|c|}{ Thermal correction to Gibbs Free Energy= } & \multicolumn{3}{|c|}{0.473764} \\
\hline \multicolumn{2}{|c|}{ Sum of electronic and zero-point Energies= } & \multicolumn{3}{|c|}{-2710.250619} \\
\hline \multicolumn{2}{|c|}{ Sum of electronic and thermal Energies= } & \multicolumn{3}{|c|}{-2710.210095} \\
\hline \multicolumn{2}{|c|}{ Sum of electronic and thermal Enthalpies } & \multicolumn{3}{|c|}{-2710.209151} \\
\hline \multicolumn{3}{|c|}{ Sum of electronic and thermal Free Energies= } & \multicolumn{2}{|l|}{2710.335411} \\
\hline \multirow{2}{*}{$\begin{array}{c}\text { Item } \\
\text { Maximum Force }\end{array}$} & Value & Threshold & Converged? & \\
\hline & 0.000061 & 0.000450 & YES & \\
\hline RMS Force & 0.000007 & 0.000300 & YES & \\
\hline
\end{tabular}

G2'

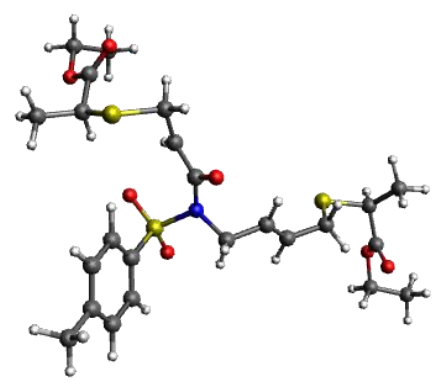

Cartesian coordinates (Angstroms): 


\begin{tabular}{|c|c|c|c|}
\hline - & -7.224 & 1.681 & -2.309 \\
\hline & -5.774 & 1.811 & -2.077 \\
\hline & -5.255 & 1.977 & -0.737 \\
\hline D & -5.956 & 2.362 & 0.201 \\
\hline N & -3.848 & 1.806 & -0.531 \\
\hline & -3.011 & 0.424 & -1.126 \\
\hline 0 & -3.620 & 0.056 & -2.408 \\
\hline 0 & -1.585 & 0.736 & -1.037 \\
\hline C & -3.371 & -0.876 & 0.056 \\
\hline C & -4.651 & -1.439 & 0.099 \\
\hline C & -4.911 & -2.444 & 1.024 \\
\hline C & -3.917 & -2.902 & 1.905 \\
\hline$C$ & -2.645 & -2.323 & 1.833 \\
\hline C & -2.363 & -1.309 & 0.916 \\
\hline C & -4.223 & -3.993 & 2.902 \\
\hline C & -3.321 & 2.357 & 0.753 \\
\hline C & -3.368 & 3.861 & 0.773 \\
\hline C & -2.276 & 4.630 & 0.809 \\
\hline C & -2.304 & 6.126 & 0.881 \\
\hline$S$ & -1.624 & 6.816 & -0.702 \\
\hline C & -1.044 & 8.503 & -0.185 \\
\hline C & 0.134 & 8.338 & 0.760 \\
\hline C & -2.142 & 9.382 & 0.410 \\
\hline $\mathrm{O}$ & 0.029 & 8.165 & 1.960 \\
\hline 0 & 1.307 & 8.380 & 0.099 \\
\hline C & 2.505 & 8.146 & 0.879 \\
\hline C & 3.020 & 9.435 & 1.501 \\
\hline $\mathrm{H}$ & -5.080 & 1.727 & -2.903 \\
\hline $\mathrm{H}$ & -5.432 & -1.105 & -0.579 \\
\hline $\mathrm{H}$ & -5.904 & -2.885 & 1.062 \\
\hline $\mathrm{H}$ & -1.860 & -2.668 & 2.501 \\
\hline $\mathrm{H}$ & -1.374 & -0.868 & 0.854 \\
\hline $\mathrm{H}$ & -4.992 & -3.671 & 3.616 \\
\hline $\mathrm{H}$ & -3.334 & -4.277 & 3.473 \\
\hline $\mathrm{H}$ & -4.605 & -4.892 & 2.403 \\
\hline $\mathrm{H}$ & -2.288 & 2.022 & 0.842 \\
\hline $\mathrm{H}$ & -3.908 & 1.944 & 1.580 \\
\hline $\mathrm{H}$ & -4.358 & 4.312 & 0.788 \\
\hline $\mathrm{H}$ & -1.287 & 4.172 & 0.778 \\
\hline & -1.667 & 6.492 & 1.693 \\
\hline
\end{tabular}




$\begin{array}{lccc}\text { H } & -3.324 & 6.491 & 1.034 \\ \text { H } & -0.676 & 8.924 & -1.126 \\ \text { H } & -2.991 & 9.445 & -0.277 \\ \text { H } & -1.762 & 10.396 & 0.589 \\ \text { H } & -2.487 & 8.986 & 1.368 \\ \text { H } & 3.217 & 7.735 & 0.160 \\ \text { H } & 2.286 & 7.397 & 1.643 \\ \text { H } & 3.194 & 10.196 & 0.733 \\ \text { H } & 3.967 & 9.246 & 2.018 \\ \text { H } & 2.303 & 9.825 & 2.230 \\ \text { C } & -6.808 & -0.740 & -3.866 \\ \text { C } & -7.126 & -2.240 & -4.014 \\ \text { C } & -7.154 & 0.023 & -5.146 \\ \text { O } & -7.976 & 0.905 & -5.264 \\ \text { O } & -6.383 & -0.431 & -6.158 \\ \text { C } & -6.564 & 0.197 & -7.454 \\ \text { C } & -5.727 & 1.461 & -7.577 \\ \text { H } & -6.833 & -2.780 & -3.109 \\ \text { H } & -6.571 & -2.652 & -4.860 \\ \text { H } & -8.196 & -2.401 & -4.183 \\ \text { H } & -7.627 & 0.406 & -7.597 \\ \text { H } & -6.244 & -0.567 & -8.166 \\ \text { H } & -6.072 & 2.222 & -6.872 \\ \text { H } & -5.818 & 1.867 & -8.591 \\ \text { H } & -4.671 & 1.249 & -7.383 \\ \text { S } & -7.707 & -0.126 & -2.383 \\ \text { H } & -5.731 & -0.631 & -3.698 \\ \text { H } & -7.559 & 2.139 & -3.240 \\ \text { H } & -7.795 & 2.070 & -1.463\end{array}$

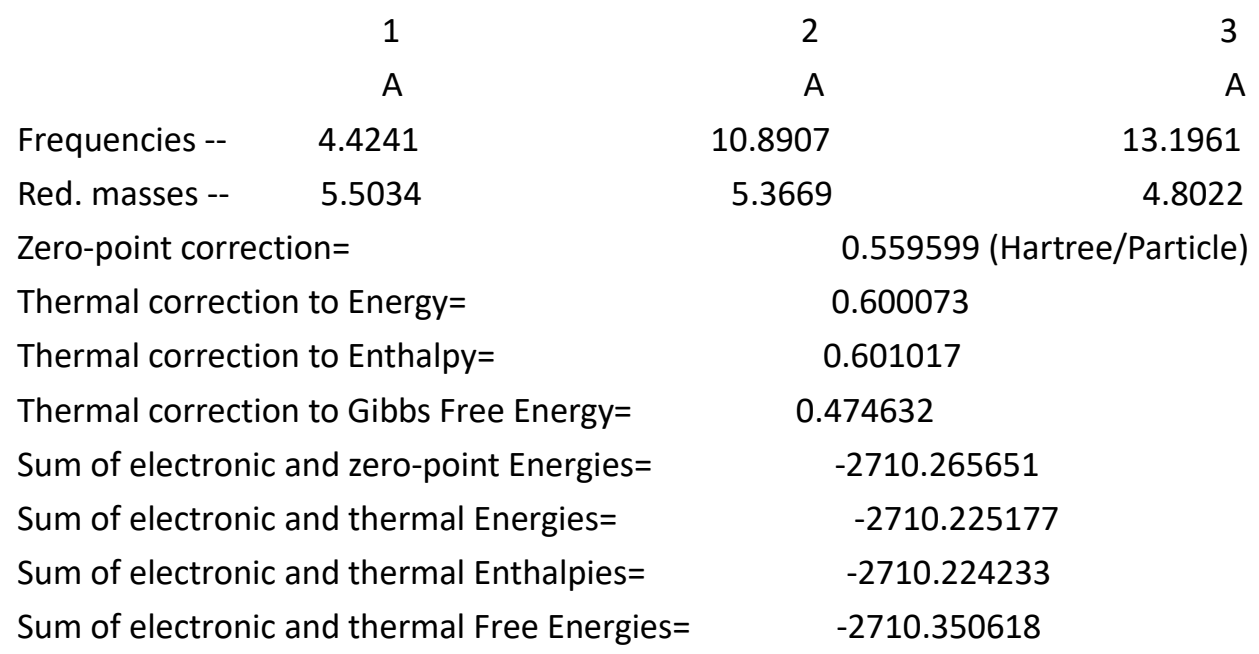

Item Value Threshold Converged? 


$\begin{array}{lrrrr}\text { Maximum Force } & 0.000043 & 0.000450 & \text { YES } \\ \text { RMS Force } & 0.000006 & 0.000300 & \text { YES } \\ \text { SCF Done: } E(\text { UB3LYP })=-2710.82524980 \text { A.U. } & \text { after } 1 \text { cycles }\end{array}$

TS2'

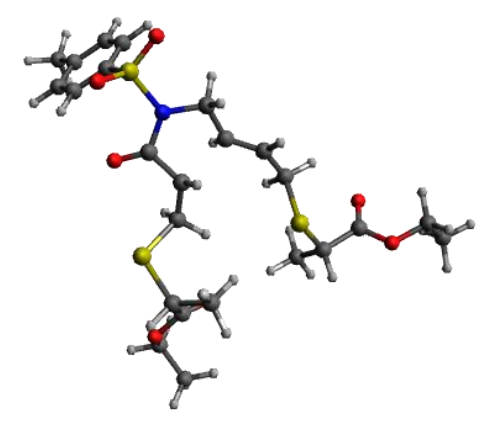

Cartesian coordinates (Angstroms):

69

$\begin{array}{lccc}\mathrm{H} & -1.236 & 3.971 & -0.179 \\ \mathrm{H} & -1.274 & 1.246 & -1.679 \\ \mathrm{H} & -0.339 & 1.934 & 0.798 \\ \mathrm{O} & -0.090 & -2.032 & 1.332 \\ \mathrm{C} & -2.244 & 3.561 & -0.125 \\ \mathrm{C} & -2.196 & 0.800 & -1.315 \\ \mathrm{C} & -2.042 & -0.302 & -0.339 \\ \mathrm{O} & -2.453 & -1.439 & -0.532 \\ \mathrm{C} & -1.327 & 1.562 & 1.098 \\ \mathrm{C} & -2.420 & 2.281 & 0.334 \\ \mathrm{C} & -3.333 & 0.720 & -2.275 \\ \mathrm{~N} & -1.439 & 0.113 & 0.851 \\ \mathrm{~S} & -0.870 & -1.018 & 2.030 \\ \mathrm{O} & -0.274 & -0.162 & 3.061 \\ \mathrm{H} & -1.421 & 1.731 & 2.174\end{array}$




\begin{tabular}{|c|c|c|c|}
\hline & -2.486 & -3.270 & 1.181 \\
\hline $\mathrm{H}$ & -3.436 & 1.944 & 0.541 \\
\hline$H$ & -4.234 & 0.340 & -1.788 \\
\hline C & -2.909 & -2.888 & 2.101 \\
\hline c & -2.337 & -1.775 & 2.723 \\
\hline C & -4.028 & -3.476 & 2.683 \\
\hline $\mathrm{H}$ & -4.476 & -4.345 & 2.207 \\
\hline c & -2.858 & -1.260 & 3.911 \\
\hline H & -2.375 & -0.418 & 4.395 \\
\hline C & -4.585 & -2.975 & 3.869 \\
\hline C & -3.980 & -1.865 & 4.474 \\
\hline H & -4.386 & -1.474 & 5.404 \\
\hline $\mathrm{H}$ & -5.916 & -3.369 & 5.532 \\
\hline C & -5.816 & -3.611 & 4.469 \\
\hline $\mathrm{H}$ & -5.792 & -4.702 & 4.368 \\
\hline $\mathrm{H}$ & -6.725 & -3.259 & 3.964 \\
\hline C & -3.346 & 4.412 & -0.662 \\
\hline$S$ & -2.943 & 4.826 & -2.429 \\
\hline C & -4.398 & 5.850 & -2.961 \\
\hline C & -4.405 & 7.133 & -2.147 \\
\hline C & -5.733 & 5.109 & -2.896 \\
\hline 0 & -4.861 & 7.227 & -1.023 \\
\hline 0 & -3.821 & 8.145 & -2.818 \\
\hline C & -3.705 & 9.411 & -2.119 \\
\hline C & -4.963 & 10.250 & -2.283 \\
\hline $\mathrm{H}$ & -3.554 & 1.694 & -2.716 \\
\hline $\mathrm{H}$ & -3.442 & 5.355 & -0.114 \\
\hline $\mathrm{H}$ & -4.304 & 3.887 & -0.616 \\
\hline $\mathrm{H}$ & -4.142 & 6.095 & -3.996 \\
\hline $\mathrm{H}$ & -5.670 & 4.164 & -3.441 \\
\hline $\mathrm{H}$ & -6.522 & 5.725 & -3.347 \\
\hline $\mathrm{H}$ & -6.023 & 4.915 & -1.860 \\
\hline $\mathrm{H}$ & -2.838 & 9.892 & -2.579 \\
\hline $\mathrm{H}$ & -3.495 & 9.212 & -1.066 \\
\hline $\mathrm{H}$ & -5.193 & 10.405 & -3.342 \\
\hline $\mathrm{H}$ & -4.819 & 11.230 & -1.815 \\
\hline $\mathrm{H}$ & -5.817 & 9.763 & -1.803 \\
\hline C & -3.250 & 0.587 & -5.185 \\
\hline C & -2.323 & 1.792 & -5.332 \\
\hline C & -4.717 & 0.980 & -5.215 \\
\hline O & -5.176 & 1.968 & -4.672 \\
\hline 0 & -5.453 & 0.083 & -5.898 \\
\hline C & -6.886 & 0.301 & -5.934 \\
\hline C & -7.275 & 1.221 & -7.081 \\
\hline
\end{tabular}




$\begin{array}{cccc}\mathrm{H} & -3.076 & -0.133 & -5.991 \\ \mathrm{H} & -2.488 & 2.526 & -4.538 \\ \mathrm{H} & -2.505 & 2.296 & -6.289 \\ \mathrm{H} & -1.279 & 1.467 & -5.305 \\ \mathrm{H} & -7.204 & 0.708 & -4.972 \\ \mathrm{H} & -7.305 & -0.700 & -6.062 \\ \mathrm{H} & -6.861 & 2.222 & -6.929 \\ \mathrm{H} & -8.366 & 1.305 & -7.137 \\ \mathrm{H} & -6.912 & 0.828 & -8.036 \\ \mathrm{~S} & -2.933 & -0.452 & -3.678\end{array}$

\begin{tabular}{|c|c|c|c|c|}
\hline \multicolumn{2}{|c|}{1} & \multicolumn{2}{|l|}{2} & 3 \\
\hline \multicolumn{2}{|r|}{$A$} & \multicolumn{2}{|l|}{$A$} & A \\
\hline \multicolumn{2}{|c|}{ Frequencies -- $\quad-409.9098$} & 10.6289 & & 12.3039 \\
\hline \multicolumn{2}{|c|}{ Red. masses -- 10.2307} & 2.3617 & & 4.9901 \\
\hline \multicolumn{3}{|c|}{ Zero-point correction= } & \multicolumn{2}{|c|}{0.558507 (Hartree/Particle) } \\
\hline \multicolumn{2}{|c|}{ Thermal correction to Energy= } & \multicolumn{3}{|c|}{0.598279} \\
\hline \multicolumn{2}{|c|}{ Thermal correction to Enthalpy= } & \multicolumn{3}{|c|}{0.599223} \\
\hline \multicolumn{2}{|c|}{ Thermal correction to Gibbs Free Energy= } & \multicolumn{3}{|c|}{0.476505} \\
\hline \multicolumn{2}{|c|}{ Sum of electronic and zero-point Energies } & \multicolumn{3}{|c|}{-2710.253626} \\
\hline \multicolumn{2}{|c|}{ Sum of electronic and thermal Energies= } & \multicolumn{3}{|c|}{-2710.213854} \\
\hline \multicolumn{2}{|c|}{ Sum of electronic and thermal Enthalpies } & \multicolumn{3}{|c|}{-2710.212910} \\
\hline \multicolumn{3}{|c|}{ Sum of electronic and thermal Free Energies= } & \multicolumn{2}{|l|}{710.335628} \\
\hline $\begin{array}{l}\text { Item } \\
\text { Maximum Force }\end{array}$ & Value & \multicolumn{3}{|c|}{ Threshold Converged? } \\
\hline Maximum Force & 0.000011 & 0.000450 & YES & \\
\hline RMS & 0.000001 & 0.000300 & YES & \\
\hline
\end{tabular}

G3' 


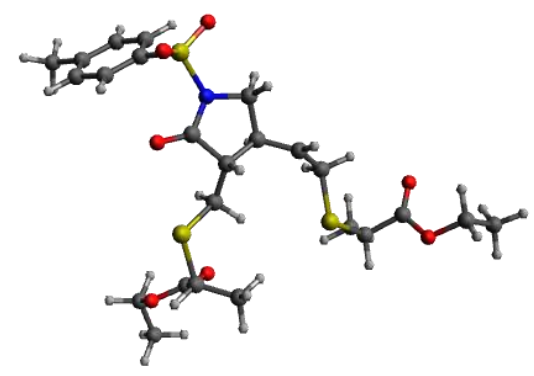

Cartesian coordinates (Angstroms):

69

$\begin{array}{lccc}\mathrm{H} & -1.973 & 4.428 & -1.069 \\ \mathrm{H} & -1.756 & 1.920 & -2.023 \\ \mathrm{H} & -1.357 & 2.818 & 0.782 \\ \mathrm{O} & -0.150 & -0.659 & 1.443 \\ \mathrm{C} & -2.985 & 4.059 & -0.909 \\ \mathrm{C} & -2.672 & 1.565 & -1.528 \\ \mathrm{C} & -2.261 & 0.372 & -0.659 \\ \mathrm{O} & -2.103 & -0.775 & -1.026 \\ \mathrm{C} & -2.318 & 2.288 & 0.775 \\ \mathrm{C} & -3.146 & 2.636 & -0.492 \\ \mathrm{C} & -3.721 & 1.222 & -2.589 \\ \mathrm{~N} & -2.110 & 0.839 & 0.644 \\ \mathrm{~S} & -1.404 & -0.087 & 1.922 \\ \mathrm{O} & -1.440 & 0.834 & 3.061 \\ \mathrm{H} & -2.844 & 2.523 & 1.701 \\ \mathrm{H} & -1.768 & -2.673 & 0.671 \\ \mathrm{H} & -4.202 & 2.434 & -0.271 \\ \mathrm{H} & -4.593 & 0.754 & -2.122 \\ \mathrm{C} & -2.509 & -2.575 & 1.454 \\ \mathrm{C} & -2.579 & -1.402 & 2.209 \\ \mathrm{C} & -3.418 & -3.596 & 1.721\end{array}$




\begin{tabular}{|c|c|c|c|}
\hline & -3.370 & -4.512 & 1.138 \\
\hline C & -3.526 & -1.244 & 3.223 \\
\hline $\mathrm{H}$ & -3.540 & -0.334 & 3.813 \\
\hline & -4.388 & -3.466 & 2.726 \\
\hline C & -4.424 & -2.280 & 3.473 \\
\hline $\mathrm{H}$ & -5.159 & -2.167 & 4.265 \\
\hline $\mathrm{H}$ & -4.898 & -5.558 & 2.943 \\
\hline c & -5.379 & -4.575 & 2.984 \\
\hline $\mathrm{H}$ & -6.175 & -4.574 & 2.227 \\
\hline $\mathrm{H}$ & -5.856 & -4.469 & 3.963 \\
\hline C & -4.109 & 4.969 & -1.221 \\
\hline$S$ & -4.185 & 5.245 & -3.077 \\
\hline C & -5.367 & 6.671 & -3.230 \\
\hline C & -4.704 & 7.905 & -2.641 \\
\hline C & -6.741 & 6.405 & -2.618 \\
\hline 0 & -4.707 & 8.182 & -1.456 \\
\hline 0 & -4.092 & 8.636 & -3.591 \\
\hline C & -3.355 & 9.803 & -3.146 \\
\hline C & -4.259 & 11.023 & -3.054 \\
\hline $\mathrm{H}$ & -4.059 & 2.144 & -3.066 \\
\hline $\mathrm{H}$ & -3.974 & 5.960 & -0.775 \\
\hline $\mathrm{H}$ & -5.065 & 4.555 & -0.887 \\
\hline $\mathrm{H}$ & -5.442 & 6.800 & -4.314 \\
\hline $\mathrm{H}$ & -7.162 & 5.478 & -3.018 \\
\hline $\mathrm{H}$ & -7.425 & 7.230 & -2.853 \\
\hline $\mathrm{H}$ & -6.678 & 6.331 & -1.529 \\
\hline $\mathrm{H}$ & -2.578 & 9.934 & -3.904 \\
\hline $\mathrm{H}$ & -2.891 & 9.579 & -2.183 \\
\hline $\mathrm{H}$ & -4.754 & 11.214 & -4.012 \\
\hline $\mathrm{H}$ & -3.665 & 11.906 & -2.792 \\
\hline $\mathrm{H}$ & -5.021 & 10.881 & -2.283 \\
\hline C & -4.015 & 0.629 & -5.389 \\
\hline C & -3.757 & 2.063 & -5.854 \\
\hline C & -5.490 & 0.369 & -5.133 \\
\hline O & -6.229 & 1.134 & -4.543 \\
\hline 0 & -5.871 & -0.830 & -5.619 \\
\hline C & -7.241 & -1.228 & -5.374 \\
\hline C & -8.175 & -0.689 & -6.447 \\
\hline $\mathrm{H}$ & -3.668 & -0.084 & -6.142 \\
\hline $\mathrm{H}$ & -4.132 & 2.795 & -5.136 \\
\hline $\mathrm{H}$ & -4.270 & 2.246 & -6.807 \\
\hline $\mathrm{H}$ & -2.686 & 2.224 & -6.001 \\
\hline $\mathrm{H}$ & -7.536 & -0.880 & -4.381 \\
\hline $\mathrm{H}$ & -7.209 & -2.320 & -5.381 \\
\hline
\end{tabular}




$\begin{array}{rrrr}H & -8.205 & 0.404 & -6.417 \\ \mathrm{H} & -9.190 & -1.066 & -6.281 \\ \mathrm{H} & -7.849 & -1.008 & -7.443 \\ \mathrm{~S} & -3.049 & 0.102 & -3.894\end{array}$

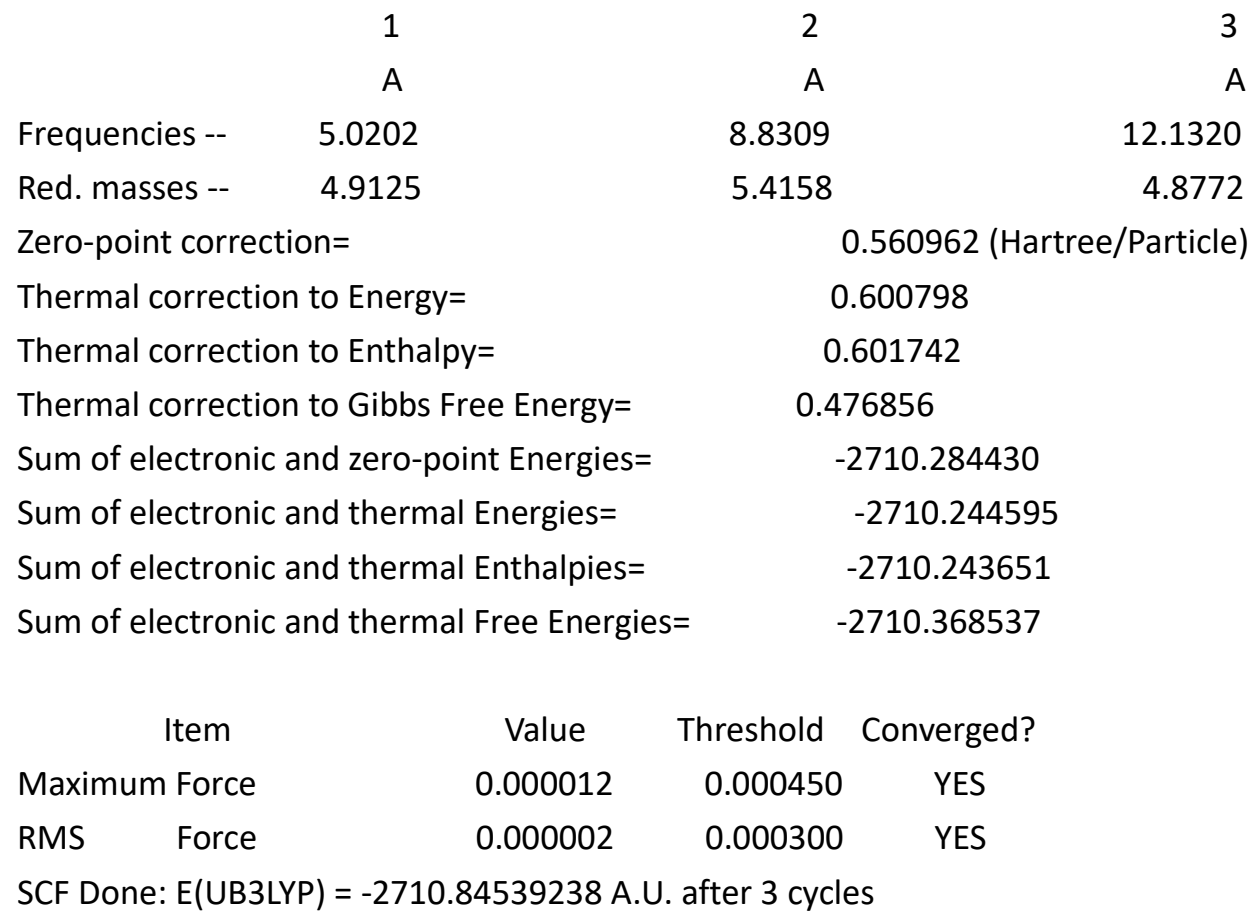

TS3'

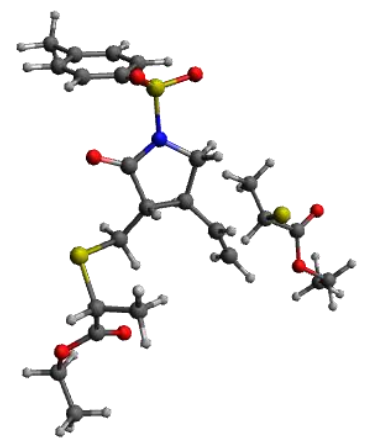

Cartesian coordinates (Angstroms): 
69

\begin{tabular}{|c|c|c|c|}
\hline 4 & -2.778 & 4.116 & -0.747 \\
\hline $\mathrm{H}$ & -2.214 & 1.678 & -1.503 \\
\hline$H$ & -1.767 & 2.776 & 1.137 \\
\hline & -0.044 & -0.545 & 1.789 \\
\hline C & -3.720 & 3.635 & -0.479 \\
\hline$C$ & -3.056 & 1.219 & -0.966 \\
\hline$C$ & -2.454 & 0.126 & -0.077 \\
\hline 0 & -2.242 & -1.029 & -0.386 \\
\hline C & -2.633 & 2.112 & 1.252 \\
\hline C & -3.614 & 2.244 & 0.060 \\
\hline$C$ & -4.078 & 0.688 & -1.973 \\
\hline N & -2.223 & 0.700 & 1.170 \\
\hline S & -1.263 & -0.034 & 2.407 \\
\hline 0 & -1.225 & 0.988 & 3.455 \\
\hline $\mathrm{H}$ & -3.102 & 2.331 & 2.212 \\
\hline $\mathrm{H}$ & -1.605 & -2.728 & 1.404 \\
\hline $\mathrm{H}$ & -4.604 & 1.900 & 0.388 \\
\hline $\mathrm{H}$ & -4.746 & -0.028 & -1.484 \\
\hline C & -2.206 & -2.626 & 2.300 \\
\hline C & -2.251 & -1.409 & 2.980 \\
\hline C & -2.964 & -3.691 & 2.786 \\
\hline $\mathrm{H}$ & -2.938 & -4.642 & 2.261 \\
\hline C & -3.023 & -1.246 & 4.134 \\
\hline $\mathrm{H}$ & -3.021 & -0.296 & 4.658 \\
\hline C & -3.752 & -3.560 & 3.937 \\
\hline C & -3.768 & -2.323 & 4.601 \\
\hline $\mathrm{H}$ & -4.368 & -2.206 & 5.501 \\
\hline $\mathrm{H}$ & -4.221 & -5.007 & 5.473 \\
\hline C & -4.557 & -4.722 & 4.468 \\
\hline $\mathrm{H}$ & -4.466 & -5.601 & 3.823 \\
\hline $\mathrm{H}$ & -5.620 & -4.467 & 4.547 \\
\hline C & -4.872 & 4.327 & -0.625 \\
\hline$S$ & -5.060 & 5.496 & 1.735 \\
\hline C & -6.765 & 4.990 & 2.238 \\
\hline C & -7.505 & 6.262 & 2.644 \\
\hline C & -6.777 & 3.949 & 3.357 \\
\hline 0 & -7.543 & 6.695 & 3.776 \\
\hline 0 & -8.100 & 6.840 & 1.582 \\
\hline C & -8.771 & 8.102 & 1.822 \\
\hline & -10.20 & 7.889 & 2.2 \\
\hline
\end{tabular}




$\begin{array}{llll}\text { H } & -4.696 & 1.501 & -2.362 \\ \text { H } & -4.893 & 5.298 & -1.105 \\ \text { H } & -5.834 & 3.855 & -0.444 \\ \text { H } & -7.250 & 4.609 & 1.333 \\ \text { H } & -6.224 & 3.057 & 3.052 \\ \text { H } & -7.807 & 3.657 & 3.601 \\ \text { H } & -6.317 & 4.357 & 4.260 \\ \text { H } & -8.738 & 8.611 & 0.856 \\ \text { H } & -8.193 & 8.673 & 2.553 \\ \text { H } & -10.761 & 7.277 & 1.578 \\ \text { H } & -10.708 & 8.856 & 2.389 \\ \text { H } & -10.216 & 7.397 & 3.270 \\ \text { C } & -3.578 & 1.031 & -4.791 \\ \text { C } & -2.863 & 2.365 & -4.584 \\ \text { C } & -5.067 & 1.214 & -5.026 \\ \text { O } & -5.762 & 2.005 & -4.415 \\ \text { O } & -5.526 & 0.375 & -5.973 \\ \text { C } & -6.953 & 0.395 & -6.231 \\ \text { C } & -7.315 & 1.464 & -7.250 \\ \text { H } & -3.157 & 0.496 & -5.647 \\ \text { H } & -3.292 & 2.918 & -3.743 \\ \text { H } & -2.965 & 2.995 & -5.476 \\ \text { H } & -1.798 & 2.198 & -4.398 \\ \text { H } & -7.477 & 0.552 & -5.285 \\ \text { H } & -7.170 & -0.608 & -6.605 \\ \text { H } & -7.105 & 2.461 & -6.854 \\ \text { H } & -8.384 & 1.405 & -7.485 \\ \text { H } & -6.752 & 1.324 & -8.179 \\ \text { S } & -3.332 & -0.193 & -3.412\end{array}$

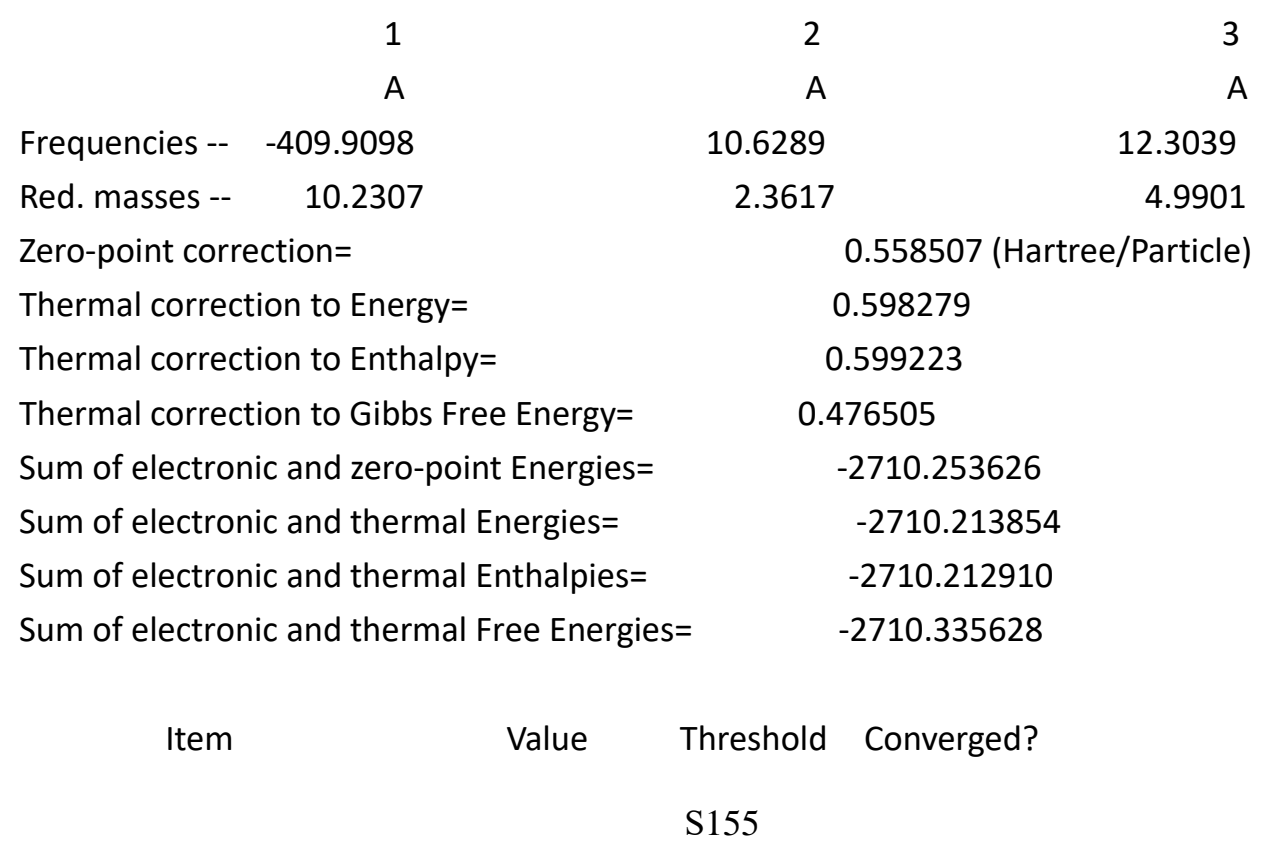




$\begin{array}{lrrrr}\text { Maximum Force } & 0.000011 & 0.000450 & \text { YES } \\ \text { RMS Force } & 0.000001 & 0.000300 & \text { YES } \\ \text { SCF Done: } E(\text { UB3LYP })=-2710.81213304 & \text { A.U. } & \text { after } 1 \text { cycles } & \end{array}$

G4sm'
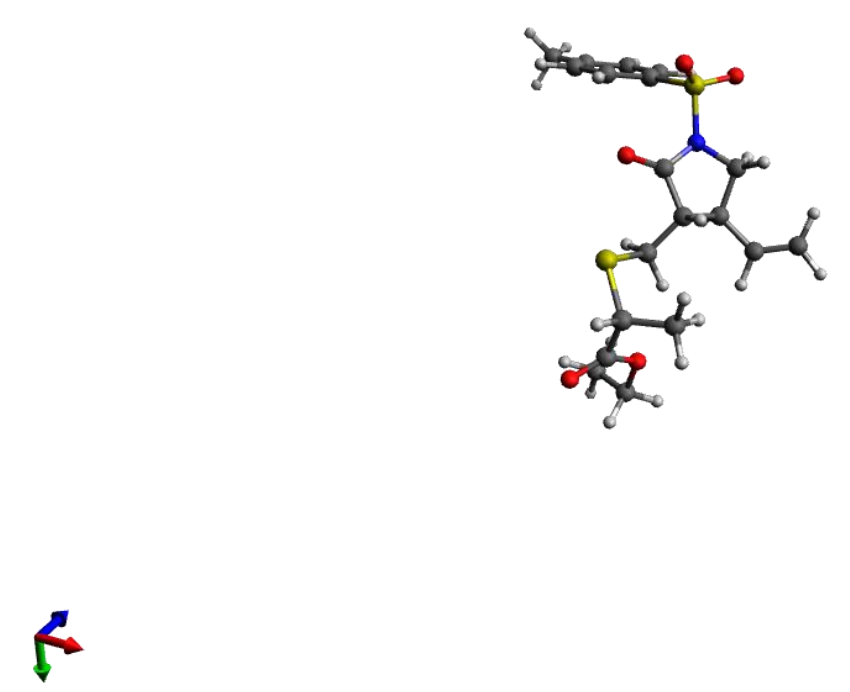

Cartesian coordinates (Angstroms):

52

$\begin{array}{lrrr}\text { C } & -6.277 & 0.239 & -3.894 \\ \text { C } & -5.542 & -0.647 & -2.887 \\ \text { C } & -6.357 & -1.878 & -2.477 \\ \text { O } & -7.144 & -2.498 & -3.163 \\ \text { N } & -6.054 & -2.137 & -1.142 \\ \text { S } & -6.503 & -3.582 & -0.308 \\ \text { O } & -6.167 & -4.721 & -1.154 \\ \text { O } & -5.903 & -3.406 & 1.017 \\ \text { C } & -8.279 & -3.468 & -0.153 \\ \text { C } & -9.098 & -3.899 & -1.200 \\ \text { C } & -10.479 & -3.828 & -1.039 \\ \text { C } & -11.053 & -3.342 & 0.145 \\ \text { C } & -10.203 & -2.928 & 1.180 \\ \text { C } & -8.817 & -2.987 & 1.041 \\ \text { C } & -12.553 & -3.257 & 0.291\end{array}$




\begin{tabular}{llll}
$\mathrm{C}$ & -5.082 & -1.188 & -0.571 \\
$\mathrm{C}$ & -5.209 & 0.018 & -1.522 \\
$\mathrm{C}$ & -4.040 & 0.964 & -1.556 \\
$\mathrm{C}$ & -2.936 & 0.904 & -0.810 \\
$\mathrm{H}$ & -7.302 & 0.418 & -3.555 \\
$\mathrm{H}$ & -5.791 & 1.213 & -3.984 \\
$\mathrm{H}$ & -4.609 & -1.019 & -3.334 \\
$\mathrm{H}$ & -8.657 & -4.267 & -2.118 \\
$\mathrm{H}$ & -11.123 & -4.162 & -1.849 \\
$\mathrm{H}$ & -10.630 & -2.562 & 2.110 \\
$\mathrm{H}$ & -8.160 & -2.686 & 1.850 \\
$\mathrm{H}$ & -12.958 & -2.420 & -0.291 \\
$\mathrm{H}$ & -12.848 & -3.107 & 1.334 \\
$\mathrm{H}$ & -13.041 & -4.168 & -0.073 \\
$\mathrm{H}$ & -4.074 & -1.618 & -0.593 \\
$\mathrm{H}$ & -5.335 & -0.955 & 0.464 \\
$\mathrm{H}$ & -6.103 & 0.586 & -1.218 \\
$\mathrm{C}$ & -5.276 & 0.602 & -6.593 \\
$\mathrm{C}$ & -3.826 & 0.647 & -6.104 \\
$\mathrm{C}$ & -5.905 & 1.971 & -6.808 \\
$\mathrm{O}$ & -6.524 & 2.293 & -7.798 \\
$\mathrm{O}$ & -5.686 & 2.799 & -5.754 \\
$\mathrm{C}$ & -6.264 & 4.126 & -5.846 \\
$\mathrm{C}$ & -7.720 & 4.133 & -5.407 \\
$\mathrm{H}$ & -5.323 & 0.115 & -7.571 \\
$\mathrm{H}$ & -3.745 & 1.085 & -5.106 \\
$\mathrm{H}$ & -3.214 & 1.255 & -6.782 \\
$\mathrm{H}$ & -3.410 & -0.364 & -6.078 \\
$\mathrm{H}$ & -6.159 & 4.479 & -6.874 \\
$\mathrm{H}$ & -5.641 & 4.736 & -5.187 \\
$\mathrm{H}$ & -8.327 & 3.522 & -6.080 \\
$\mathrm{H}$ & -8.108 & 5.158 & -5.429 \\
$\mathrm{H}$ & -7.824 & 3.749 & -4.387 \\
& -4.143 & 1.785 & -2.267 \\
\hline & -2.766 & 0.128 & -0.069 \\
\hline & -6.394 & -0.488 & -5.587
\end{tabular}

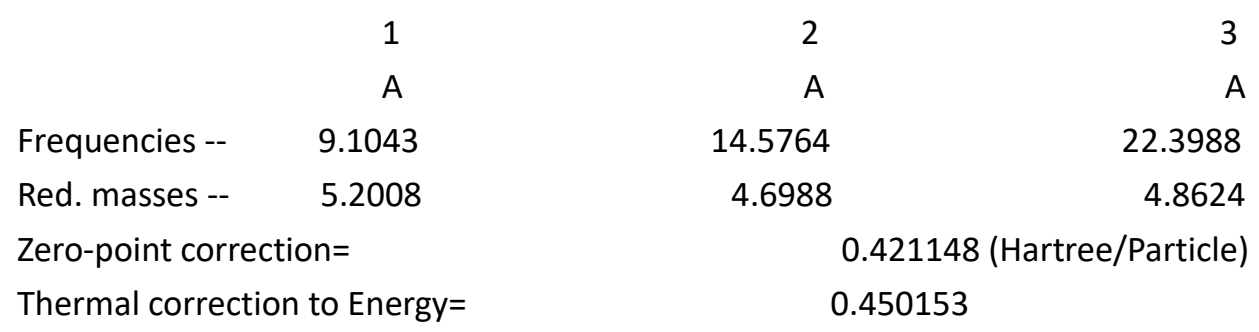




\begin{tabular}{|c|c|c|c|}
\hline Thermal correctic & & & .451097 \\
\hline Thermal correctic & ree Energy= & 0.35 & 55683 \\
\hline Sum of electronic & int Energies & & -1965.844168 \\
\hline Sum of electronic & Energies= & & -1965.815163 \\
\hline Sum of electronic & Enthalpies & & -1965.814219 \\
\hline Sum of electronic & Free Energ & & -1965.909633 \\
\hline Item & Value & Threshold & Converged? \\
\hline Maximum Force & 0.000016 & 0.000450 & YES \\
\hline Force & 0.000002 & 0.000300 & YES \\
\hline
\end{tabular}

2. Single Point Energy (Hartree)

$\begin{array}{ll}\text { G2 } & -2463.58557174 \\ \text { G3 } & -2463.60909829 \\ \text { G4so } & -895.15672732 \\ \text { TS1 } & -2463.54876981 \\ \text { TS2 } & -2463.57314895 \\ \text { TS3 } & -2463.60310366 \\ \text { TS4 } & -895.14929361 \\ \text { G4sm } & -1568.45814455 \\ \text { G5sm } & -346.47937287 \\ \text { SO2 } & -548.67198243 \\ \text { sm } & -2117.08498727 \\ \text { TS1C } & -2463.54086828 \\ \text { G2C } & -2463.57034821 \\ \text { TS2C } & -2463.56376389 \\ \text { G3Csm } & -1568.42143413 \\ \text { sm' } & -1966.64486855 \\ \text { G4s } & -744.70289938 \\ \text { TS1' } & -2711.34304374 \\ \text { G2' } & -2711.35863659 \\ \text { TS2' } & -2711.34619465 \\ \text { G3' } & -2711.37980405 \\ \text { TS3' } & -2711.37256152 \\ \text { G4sm } & -1966.66880803\end{array}$

